\title{
DEVELOPMENT TRENDS OF THE MODERN PHILOLOGY
}

\author{
Collective monograph
}

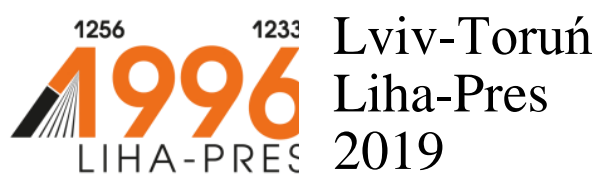




\section{Reviewers:}

dr Adam Wróbel, School of Polish Language and Culture of Cuiavian University in Wloclawek (Republic of Poland);

mgr Joanna Skiba, Director of the Center for Foreign Languages, Cuiavian University in Włocławek (Republic of Poland).

Development trends of the modern philology : collective monograph / D. Ch. Chyk, I. I. Dmytriv, P. V. Ivanyshyn, N. V. Maftyn, etc. -Lviv-Toruń : Liha-Pres, 2019. - 240 p. ISBN 978-966-397-140-7

Liha-Pres is an international publishing house which belongs to the category „C" according to the classification of Research School for Socio-Economic and Natural SENSE Sciences of the Environment (SENSE) [isn: 3943, 1705, 1704, 1703, 1702, 1701; prefixMetCode: 978966397]. Official website - www.sense.nl. 


\section{CONTENTS}

THE PROSE DISCOURSE OF UKRAINIAN LITERATURE

OF THE LATE 18TH TO MID-19TH CENTURIES:

THE PROBLEM OF CANON FORMATION

Chyk D. Ch.

1

THE LITURGICAL SONGS IN CREATIVE WORK

OF BOHDAN-IGOR ANTONYCH

Dmytriv I. I.

THE MEANING OF THE KNIGHT RANK OF IVAN GONTA

IN "HAYDAMAKS" BY TARAS SHEVCHENKO:

HERMENEUTICAL-COMPARATIVE ASPECT

Ivanyshyn P. V.

"PHILOSOPHY OF ACTION" IN THE PROJECTION

OF “AUTHORITATIVE STYLE” OF ULAS SAMCHUK

Maftyn N. V. .58

CREATIVITY BY IVAN FRANKO:

PSYCHOANALITICAL HORIZONS

OF UKRAINIAN-AUSTRIAN LITERARY INTERACTIONS

Pecharskyi A. Ya., Zymomrya I. M .84

COGNITIVE AND PSYCHOLINGUISTIC NATURE

OF METAPHOR AS A BASIS OF AUTHOR'S CONCEPTUAL

SYSTEM IN POETRY

Chendey N. V 107 
SPEECH ACCENT IN BILINGUALS' SPEECH

Devitska A. I. 128

VERBALIZATION OF POLITENESS IN MODERN ENGLISH

Fabian M. P. 148

SEMANTIC BASIS OF ENGLISH

AND UKRAINIAN ASTRONOMY TERMS

Rohach L.V. 168

METHODS OF TERMINOLOGICAL COMPOSITION

EXTENSION IN LANGUAGES FOR SPECIAL PURPOSES

IN THE GERMAN CHRISITIAN THEOLOGICAL

TERMINOLOGY

Veresh M. T. 194

SPECIALIZED MEDICAL INFORMATION SPACE:

HISTORY AND PRINCIPLES OF FORMATION

Sadivnychyi V. O 213 


\section{THE PROSE DISCOURSE OF UKRAINIAN LITERATURE OF THE LATE 18TH TO MID-19TH CENTURIES: THE PROBLEM OF CANON FORMATION}

\section{Chyk D. Ch.}

\section{INTRODUCTION}

The literary canon is still often interpreted as a definite list of norms that "push" the works that lack certain invariable aesthetic features from the top of the literary process. The list of "eternal" and "ingenious" works, which is inherent in almost all national literatures, is proclaimed inviolable - overcoming this constancy is often helped by the change of ideological or aesthetic paradigms, personal preferences of the researcher or even the literary studies' or textbooks' volume that "automatically" cross out certain surnames.

In his literary bestseller "The Western Canon: The Books and School of the Ages" (the 1st ed. - 1994) an American literary critic Harold Bloom, developing his own Western literatures canon scheme, transferred an Italian philosopher Giambattista Vico's idea about the three main stages of the nation development (theocratic, aristocratic, democratic) on the world literary process ${ }^{1}$. It is clear that Bloom's mythological scheme of William Shakespeare's "sacralisation" reflects in some way the subjective aesthetic sympathies of the author, which, if one change their perspective, methodology and central persona, can also be reasonably revised. For example, due to a Ukrainian scholar Borys Shalaginov, Johann W. von Goethe and his "Faust. Eine Tragödie" ("Faust: Tragedy") replaced Shakespeare's post-medieval era, and formed the "heart" of the New European canon. The basis for the German writer's centering is his proclamation of the art's exceptional importance, the emergence of a modern life understanding, the mythological thinking foundation of the

${ }^{1}$ Блум Г. Західний канон: книги на тлі епох / пер. 3 англ. під заг. ред. Р. Семківа. Київ : Факт, 2007. С. 5-6. 
modern era and the perception of man as a culture creator ${ }^{2}$. However, in the case of the colonized peoples' literatures, in particular the Ukrainian one, the civilizational concept of Vico, capable in general for most Western European and American literatures, in Bloom's interpretation (with an emphasis on creative aesthetism) needs at least reconsideration. For example, the "extra" era in the literature history can be called colonial and in the nominal "scheme due to Vico" it will take the place of the democratic epoch after the aristocratic one.

The Ukrainian literature in its current canon format requires a thorough revision and detachment of a considerable number of outdated views and stereotypes that have been inherited from Soviet literary studies $^{3}$. In addition, the canon of the history of Ukrainian literature is often regarded as one that should present exclusively Ukrainian-language pieces of fiction that embody national identity. As a consequence, a large number of works written in Russian, Polish or other languages are ignored, which, I believe, can be counted as elements of two or more canons at the same time due to the author's language usage, or writers who are rejected ex cathedra for one reason or another (they had to leave their homeland and sought after self-realization ways in the metropolis (the reasons might be different - education, civil or military career, the search for writer's glory, etc.) and had since then been territorially tied to a foreign country, creating its, but also and their own cultural product).

\section{The problem of literary identification of Ukrainian Russian-writing writers}

The age-old problem of Ukrainian literary criticism is the issue of literary (self-)identification of Ukrainian Russian-writing writers of the $1^{\text {st }}$ half and mid-19th centuries. I should first mention Vasyl Kapnist, Vasyl Narizhny, Pavlo Biletsky-Nosenko, Orest Somov, Alexander Perovsky (Antoniy Pogorelsky), Ivan Kulzhinsky, and, of course, Mykola Gogol

${ }^{2}$ Шалагінов Б. «Фауст» Й. В. Гете як центр новоєвропейського літературного канону // Б. Шалагінов. Класики і романтики: Штудії з історії німецької літератури XVIII - XIX століть. Київ : Києво-Могилянська академія, 2013. С. 47-48.

3 Александрова Г. Глобалізація i нові стратегії в компаративістиці // Українознавчий альманах. 2013. Вип. 11. С. 79. 
(I have to mention here and such bilingual writers, as Yevhen Grebinka, Grygoriy Kvitka (Grytsko Osnovyanenko) and Taras Shevchenko) and others. Getting higher education in the capital's institutions, working in the imperial state system (in its civilian or military dimensions), and often forced usage of the Russian language in literary creativity, have prompted many critics to consider these authors' achievements in the context of Russian literature, while being "distinctly different" from the Ukrainian literature. After all, the prospect of considering Ukraine as a self-sufficient state (in those times it was a colony of the Austrian and Russian empires) with its own people and, accordingly, linguistic, cultural, historical traditions and peculiarities, is now constantly being questioned.

If the researcher follows the pro-imperial logic, it should be noted that almost all the writers who worked in Ukraine before 1917 he must regard as mainly Russian and Austrian authors. This difficult issue is already being attempted to solve, at least theoretically, by contemporary literary critics. The opinion of an Ukrainian researcher Oleksandr Glotov, who offers along with the main parameters of determining the literary affiliation of a writer and the option of including the works written in Russian through objective historical circumstances in the history of Ukrainian literature, is noteworthy ${ }^{4}$ (the list can be continued: Hebrew, German, Polish works, etc.). The creation of the "great" history of Ukrainian literature, proposed by the researcher, provides the parallel entry of the texts mentioned into other canons. It is often the language marker that has become a barrier to this approach.

After the state forbid on Ukrainian-language bookselling and the liquidation of the Cossack Hetmanate in the 18th cent., the Russian language became the dominant language of high Ukrainian culture. Therefore, even those texts of the first decades of the 19th century which were "subversive" to imperial discourse, like an anonymous "Istoriya Rusov, ili Maloy Rosii" ("History of Ruthenians or Little Russia"), were written in Russian. During this period, the Little Russian elite had already formed, which, with an amazing ability, combined Russian royalism with Ukrainian nobility, thus creating a new degree of its own consciousness.

4 Глотов О. Російська література України: методологія питання // Теорія літератури. Компаративістика. Україністика: зб. наук. праць 3 нагоди 70-річчя професора Романа Гром’яка // Studia methodologica. 2007. Вип. 19. С. 30. 
The elite also used the newly created Russian literary language, which at that time completely replaced the old Ukrainian language, and instead of Latin the Ukrainian noble studied French - the language of the Russian aristocracy - and adopted the customs of the imperial capital (these metamorphoses in the traditions of the Ukrainian nobility are satirically illustrated by G. Kvitka-Osnovyanenko in his novel "Pan Khaliavsky" ("Lord Khaliavsky")). A modern Canadian historian Zenoviy Kogut writes about the dialectical process of formation of Little Russian identity and its important role in the process of Ukrainian national state building ${ }^{5}$ :

Due to the interest in antiquity and nostalgia for it, the Ukrainian nobility managed to preserve the remains of Little Russian identity until the 1830s and 1840s. At the same time, under the influence of Herder and Romanticism, the next generation discovered the Ukrainian people with its original language ${ }^{6}$.

An illustrative case of the "Russian canonization" specifics is Vasyl Kapnist, a Ukrainian-Russian poet and playwright whose most of his life was connected with Ukraine. Having gained his fame as a writer after the release of a satirical comedy in verse "Yabeda" ("The Sneak") (1798), which in the canon of Russian dramaturgy of the 18th century comes immediately after the play "Nedorosl" ("The Minor") (1782) by Denis Fonvizin (von Wiesen), V. Kapnist held the second "honourable" place in the Russian playwrights pantheon until the appearance of "Gore ot uma" ("Woe from Wit") (1825) by Alexander Griboyedov. The litigation of Ukrainian landlords, satirically portrayed in the comedy "The Sneak", would later become the main form of unfolding events in the Ukrainian stories of "Dva Ivana, ili Strast k tyazhbam" ("Two Ivans, or the Passion for Litigation") (1825) by V. Narizhny and "Povest o tom, kak possorilsya Ivan Ivanovich s Ivanom Nikiforovichem" ("The Tale of How Ivan Ivanovich Quarreled with Ivan Nikiforovich”) (1834) by M. Gogol ${ }^{7}$.

\footnotetext{
${ }^{5}$ In all the excerpts the translation from Ukrainian or Russian is mine unless noted otherwise. - D. Ch.

${ }^{6}$ Когут 3. Розвиток малоросійської самосвідомості і українське національне будівництво // 3. Когут. Коріння ідентичности. Студії з ранньомодерної і модерної історії України. Київ : Критика, 2004. С. 99.

${ }^{7}$ Берков П.Н. История русской комедии XVIII в. Ленинград : Наука, 1977. С, 353. 
The choice of the metropolis language, participation in empire military (service in the army) and noble institutions (V. Kapnist held various elected positions in the Kyiv and Poltava provinces), active literary activity (publication of poetic works in Russian magazines) - all these factors allegedly serve in favor of Kapnist's exclusive affiliation with the Russian literature. However, texts like "The Sneak", which in a disguised form raise the Ukrainian problems, also belong to the Ukrainian literary canon.

I would like to draw the reader's attention to the formation of the Russian literary canon in the 1820s-1830s, which (without taking into account national, cultural and, finally, literary features) contains Ukrainian and Polish writers. It is clear that this approach was primarily in line with imperial interests and ambitions, which needed a fuller appreciation in the arts. An illustrative example is the treatise "On Romantic Poetry" (1823) by the Ukrainian-Russian writer Orest Somov, who without any hesitation refers Ukrainians, Lithuanians, Poles, Tatars, Finns, Caucasians to Russians, emphasizing that the history and culture of these peoples can provide rich material for fictional writing ${ }^{8}$. It was at this time that the discussion was taking place between apologists of Russian and Little Russian literature, the essence of which was to acknowledge or deny the distinctness and self-sufficiency of literature in the Ukrainian language. Often, these disputes moved into the realm of purely artistic texts - like the first Ukrainian-language short story "Saldatsky Patret" ("The Portrait of a Soldier") by G. Kvitka-Osnovyanenko, written with the special purpose of preventing the writer from biased assessment of Russian journalists and literary critics for the first Ukrainian-language novelette "Marusya" or a literary manifesto like "Suplika do pana izdatelya" ("The Announcement to Mr. Publisher") by the same author who upheld the right of Ukrainian literature to exist.

Therefore, the period of functioning of the literature of colonized Ukraine at the end of 18th - the middle of the 19th cent. should be considered in the light of historical features, cultural situation, but without such

${ }^{8}$ Сомов О.О романтической поэзии: опыт в трех статьях. Санкт-Петербург : В Тип. Имп. Воспитательнаго Дома, 1823. С. 86-87. 
widespread idea of "romanticized Ukrainian nationalism" in some recent literary works (according to Olena Yurchuk's apt phrase) ${ }^{9}$. Here, in particular, the concept of the nation of American political scientist Benedict Anderson may prove useful. The notion of an "imagined community" as a political and genetically restricted unity whose representatives experience in their minds an image of involvement ${ }^{10}$, allows to characterize more precisely the initial stage of Ukrainian nation formation of the early 19th century within the multiethnic empires mentioned, and which identified itself within the "Little Russian" or "Rusyn" community (in Galicia, for instance, Ukrainian identity was also formed in the struggle - first of all, with Polophilic and partly Russophile tendencies). National patriotism was replaced by regional patriotism, which often existed - paradoxically - in close connection with imperial patriotism.

The above facts does not confirm the complete absence of national patriotism and its hidden (for obvious reasons of self-protection under conditions of totalitarian censorship) manifestations in the diariuszes (diaries) and epistolaries of the Ukrainian elite. As Tamara Gundorova remarks, in the Russian literature of the early 19th century hybridity was inherent, which was to demonstrate a degree of cultural integration into the imperial "body" ". However, in the 1820-1830's, most texts of Ukrainian writers encounter the dual language of mimicry inbuilt in cultural hybrids, as representatives of postcolonial criticism, like the American researcher Homi Bhabga, emphasize in their writings.

The Ukrainians were not yet the sole "imagined community" because of the actual lack of political identification, the rudimentary state of ideas of sovereignty and nationalism, the unequivocal interpretation of their own historical and cultural roots. The first attempt to overcome this "Little Russian" duality was made by members of the secret "Slavic Brotherhood of St. Cyril and Methodius", who planned to replace imperial patriotism with Slavic ones. In their programme "Knyha buttia ukrainskoho narodu"

\footnotetext{
${ }^{9}$ Юрчук О.У тіні імперії: українська література у світлі постколоніальної теорії : монографія. Київ : Академія, 2013. С. 19.

${ }^{10}$ Андерсон Б. Уявлені спільноти. Міркування щодо походження й поширення націоналізму. Київ : Критика, 2001. С. 22-25.

${ }^{11}$ Гундорова Т. Микола Гоголь і колоніальний кітч // Гоголезнавчі студії. Ніжин, 2009. Вип. 18. С. 25.
} 
("Zakon Bozhyi")" ("The Book of Being of the Ukrainian People" ("The Law of God")) by one of the most famous "brothers" Mykola Kostomarov one can observe manifestations of "primary" nationalism and the search for a theoretical basis for cultural autonomy, on which the national idea would grow much later. In the article "Two Russian Nationalities (A Letter to the Editor)" (1861), declaring the proximity of "Great Russians" and "South Russians" (as opposed to the closeness of Ukrainians and Poles), he put forward a number of arguments on the benefit of the Ukrainian national individuality ${ }^{12}$.

The Ukrainian writers of the 1 st half of the 19th cent. is also an "imagined community" whose members in their literary work saw the national literature development quite differently and often in diametrically opposed paradigms - colonial, imperial or national. Such pluralism of views led to dissimilar linguistic choices, genre orientation, and reception of other European literatures. Exemplary, for instance, are the bilingualism and diversity of the professional activities of G. Kvitka-Osnovyanenko and Ye. Hrebinka, who at the same time actively participated in the creation of Ukrainian and Russian national literatures.

As expected, the creation of a lasting imperial view of colonial Ukraine was partly aided by the writers who presented it in the Russian literature. The attempt to portray Little Russia in a down-to-earth form (as a peripheral wilderness in the "enlightened" empire backyard) was unintended or inadmissible to the generally accepted imperial stereotypes inherent in certain pieces of fiction of Russian-speaking writers who were Ukrainians (then - Little Russians) and served in public or military institutions of the metropolis, for obvious reasons linking their literary progress with the highly cultured "northern capital". Some authors, paradigmatically referring to Russian and Ukrainian literature, simultaneously chose in their works such topoi and concepts that would testify to the conscious choice of imperial ideology.

The most researched and paradoxically controversial is also the problem of the formation of Ukrainian literature in the 1st half of the

${ }^{12}$ Костомаров Н. Две русские народности (Письмо к редактору) // Основа. 1861. № 3. C. 33-80. 
19th cent., in particular the genesis and development of a prose genres' system, which attests to all the contradictions of the contemporary literary process. The complex issue of incorporating Ukrainian Russian-language and Ukrainian-language literature into Russian literature is less studied: for understandable and discussed reasons, the "undeniable and irreversible influence" of Russian literature on Ukrainian writers has been largely considered. Even the creativity of 19th-century Ukrainian writers, often written in Russian, was often regarded as an integral part of Russian literature, like the Russian-language works of G. Kvitka-Osnovyanenko and Ye. Hrebinka ${ }^{13}$. This obvious declaration may also serve as a forced "statement", which here acquires an ironic denotative meaning:

"Great Russian literature of the 19th - 20th cent. helped Ukrainian literature to develop, nourished it with advanced ideas, supported it in difficult moments" $"$.

It is clear that the inclusion of V. Narizhny or M. Gogol in the Ukrainian literature was impossible in the works, since the authors were considered exclusively as Russian writers, but a comprehensive study of this issue would give an unbiased modern assessment of UkrainianRussian literary relations.

It should be noted, however, that there is a recent trend of a certain updating of the Ukrainian literature canon, based on new methodological approaches and principles that could be applied in the analysis of other periods. Thus, a modern Italian researcher Giovanna Brogi Bercoff proposes to consider Ukrainian Baroque literature as an independent "canonical" system and part of a wider system that incorporates the canons of neighboring literatures and, even more broadly, the canons of European literatures $^{15}$. After all, the phenomenon of incorporating Ukrainian literature into the literatures of neighboring countries, in particular Russian or Polish, is noticeable in the following centuries; this, after all, is still ongoing in our time. However, some contemporary studies, emphasizing

13 Зубков С. Д. Русская проза Г. Ф. Квитки и Е. П. Гребенки в контексте русскоукраинских литературных связей. Київ : Наук. думка, 1979. 272 с.

${ }^{14}$ Білецький О. І. Гоголь і українська література // Гоголь і українська література XIX ст. : зб. ст. Київ : Держ. в-во худ. літ., 1954. С. 3.

15 Беркофф Дж. Б. Чи існує канон українського літературного Бароко? // Український гуманітарний огляд. 2012. Вип. 16-17. С. 13. 
the dominance of a purely national issue of a writer's work, removing pieces of fiction from a non-literary context, "place" them in a sterile and closed dimension for other literatures.

I'll briefly outline some planes for the creation of the term "canon". Jan Assmann convincingly puts in the semantic field of this term the invariance category, which implies the presence of points of support, equality, accuracy. Invariance is a kind of "sanctification" that secures the "inviolability" of a work of art. Being legal and authoritative, the canon, in the context of changing traditions, aims to present compulsory rules and regulations. It also provides for polarization, a clear delineation between elitist and mass literature. Jan Assman, as one of the authors of the concept of collective memory, defines the canon as a stabilizer of the collective consciousness, which at the same time presents the personal ${ }^{16}$.

It is clear that the problem of the formation of national literatures in the context of colonization is relevant to many postcolonial literary studies and requires methodological approaches that would not restrict the inclusion of authors in the canons and would not unjustifiably expand it. Marko Pavlyshyn sees the restriction of the canon of Ukrainian literature in the type of recipient, to whom representatives of a "narrow" canon (representatives of an ethno-cultural nation) are oriented. Provided that the reader is being reoriented to represent the civic nation, the canon works will not represent exclusively the ethno-national narrative discourse ${ }^{17}$. The researcher points out that with regard to Ukrainian literature of the 1st half of the 19th cent. one should always bear in mind its ethnocultural multifacetedness, which is also characteristic of subsequent periods. Expressing only the Ukrainian narrative is not only detrimental to the complete study of this peculiarity, but also specific manipulation for the sake of realizing the complex of the "little brother".

${ }^{16}$ Ассман Ян. Культурная память: Письмо, память о прошлом и политическая идентичность в высоких культурах древности / пер. с нем. М. М. Сокольской. Москва : Языки славянской культуры, 2004. С. 130-138.

${ }^{17}$ Павлишин М. Історія літератури і здоровий глузд // Історії літератури : збірник статей / упоряд. О. Галета, Є. Гулевич, 3. Рибчинська (Центр гуманітарних досліджень ЛНУ ім. Івана Франка). Київ : Смолоскип ; Львів : Літопис, 2010. С. 21. 


\section{Ukrainian literature of the 19th cent.: new research perspective for studying}

One of the most productive new research perspectives for studying Ukrainian literature of the 19th cent. I consider to be is the one projected by a contemporary Kazakh researcher Nurbolat Dzhuanishbekov. For the analysis of Kazakh literature of the era of socialist realism, he proposes a theory of integrative literature that can be applied to studying of other colonial-period literatures like the Ukrainian one. N. Dzhunyshbekov understands integrative literature as a special form of synthesis of literature and other forms of social consciousnesses, which, as a result, constitutes "frontier" synthesized literature with its distinct typological features. In such literature the scientist recommends to distinguish the following typological groups depending on the level of integration: adaptive, differential, convergentive, biliterary, and assimilative $^{18}$. I'll consider the Ukrainian literature of the late 18th to mid19th centuries, using this classification.

In the first group - the adaptive one - there are writers who, in various forms of reception (mainly adaptation and translation), represent inter-literary connections (Ivan Kotlyarevsky, Petro Gulak-Artemovsky, Leonid Glibov). The works of these writers are usually written in their own language, like the mock-heroic poem by I. Kotlyarevsky "Eneyida" ("Aeneid"), whose intertextual background is extremely rich. In among the European "Aeneids" the literary work of I. Kotlyarevsky holds the first place of honor. The writer created an alternative and foreign-language project of colonized literature within the imperial baroque literature (this tradition was later successfully destroyed by T. Shevchenko). The originality of the idea served as a catalyst for a large number of imitations, which became an interesting and peculiar literary phenomenon under the generalized name Kotlyarevschyna (P. Biletsky-Nosenko, P. Korenytsky, K. Puzyna, etc.). The main function of Kotlyarevschyna was the unmasked delimitation of the Russian literature through the choice of a specific language code ${ }^{19}$.

18 Джуанышбеков Н. Типологические группы интеграционной литературы // Літературна компаративістика. Вип. III. Ч. І. Київ : Стилос, 2008. С. 45-46.

${ }^{19}$ Грабович Гр. Семантика котляревщини // Гр. Грабович. До історії української літератури: Дослідження, есе, полеміка. Київ : Основи, 1997. С. 321. 
The second - differential - group is represented by bilingual creativity of writers representing national originality (Levko Borovikovsky, Taras Shevchenko, Grygoriy Kvitka-Osnovyanenko, Panteleymon Kulish, Markiyan Shashkevich, Mykola Ustyianovich, Oleksa Storozhenko, Marko Vovchok and others). The foreign-language part of their creative writing is often not as representative as the Ukrainian-language pieces of fiction.

T. Shevchenko's poetic works, promoting the idea of national revival, at the same time outlined fundamental ways to preserve and develop Ukrainian identity. In his anti-imperial poem "Velykyi L'okh" ("The Great Cellar") the poet called for a struggle against the Russian occupation and expressed a prophetic hope for the revival of Ukraine ${ }^{20}$. According to many literary critics, Shevchenko's Russian-language prose is less aesthetically valuable. It happened, according to Ivan Dzyuba, because of the implicit orientation of the stories to the Russian reader (the reason for the transition to Russian, according to many researchers, was the simple desire to receive a fee for publication in fiction magazines), to which the writer tries to show the true identity of Ukraine - its language, history and culture. However, even lagging behind literary fashion (sic!) and the forced "excommunication" from the then Russian canon did not destroy the original world of the poet Shevchenko in his new role as a prose writer ${ }^{21}$. It should be noted that the issue of Russian-language prose by T. Shevchenko is not limited to the conjuncture or a certain orientation to the literary taste - it is first and foremost an interesting author project that demonstrates the hidden game of an experienced writer with a reader.

The group also includes the artistic achievements of the well-known founder of Ukrainian-language prose G. Kvitka-Osnovyanenko, whose works trace the evolution from classicism and sentimentalism to preromanticism and realism. It is the Ukrainian-language and Russianlanguage prose of the writer that has become to some extent a utopian project, since it creates a mythologized history of everyday life in Sloboda

${ }^{20}$ Шкандрій М. В обіймах імперії: російська і українська літератури новітньої доби / [пер. П. Таращук]. Київ : Факт, 2004. С. 233-236.

${ }^{21}$ Дзюба I. М. Тарас Шевченко. Життя і творчість. 2-ге вид., доопрац. Київ : Києво-Могилянська академія, 2008. С. 469-472. 
Ukraine (Slobozhanshchyna, Slobidska Ukrayina) ${ }^{22}$ of the 18 th - the $1^{\text {st }}$ half of the 19th cent. In his Ukrainian-language stories the center of the province sometimes even acquires sacred features. In my opinion, it is worth quoting the description of Kharkov - a provincial city, a kind of "capital" of Slobozhanshchyna - from one of his stories:

A good city of Kharkov, big, cheerful; there are lots of the churches of God, the lords' mansions, state residences; there are many houses, the schools of every kind - both for young lords and for young ladies, - the holy father lord's dwelling, the post office, the prison castle - o my father, there are every type of houses in it! Nice and big ones and each is built from stone, and their tops are painted with green paint ... Or a bell tower in the city... If you want to see the top of it, first put your hat on, and then raise your head, fix your eyes on until you see its top with the holy cross; and be attentive, though the hat will not blow off, but you will probably stagger: such high our bell tower is. And how many streets in Kharkov, oh my father! Long and straight are they, and there are some paving ones also: so you don't have to be afraid to cart when it is very bad weather - you will not get stuck in the mud, even if you have got really bad oxen ${ }^{23}$.

In one of his historical essays written on the slope of the age, G. Kvitka-Osnovyanenko narrates a family legend about how Kharkov was founded by his ancestors - sons of a Moscow boyar. As Olexander Borzenko comments, such retelling had a twofold purpose: to justify claims for a privileged place among the nobility of Sloboda Ukraine and emphasize the longstanding connection with the Moscow noble families ${ }^{24}$. Thus, a descendant of the ancient Cossack family makes an attempt to explain their own bizarre combination of local patriotism and devotion to the Russian empire. Even his Russian-language prose and author's translating, often criticized by his contemporaries for the "style difficulty", became a representation (albeit often sentimental) of the Ukrainian

${ }^{22}$ A historical region, now located in North-Eastern Ukraine and South-Western part of the Russian Federation.

${ }^{23}$ Квітка-Основ'яненко Г.Ф. Зібр. творів у 7-ми т. / [ред. колегія : П. М. Федченко, О.І. Гончар, Б.А. Деркач, С.Д. Зубков, Д. В. Чалий]. Київ : Наук. думка, 1978-1981. Т. 3. 1980. C. 304.

${ }^{24}$ Борзенко О.I. Сентиментальна «провінція»: (Нова українська література на етапі становлення). Харків : Харків. націон. ун-т ім. В. Н. Каразіна, 2006. С. 216. 
province and its opposition to the imperial center. Thus, in the novels "Zhizn i pokhozhdenyia Petra Stepanova syna Stolbikova, pomeshchika v trekh namestnichestvakh. Rukopis XVIII veka" ("The Life and Adventures of Petro Stepanov, Son of Stolbikov, a Landowner in Three Governorates. Manuscript of the XVIII century") and "Pan Khalyavsky" images of two Russian capitals - Moscow and St. Petersburg - are ridiculous. Ukrainian nobles - the descendants of the former Cossack nobility, who are the recipients of the customs of the capital - are also parodied. However, everything becomes clear, if one takes into account the conditions in which the writer was forced to create, defending Ukrainian-language literature in its officially authorized provincial version from biased and often chauvinistic attacks of Russian literary critics.

Panteleimon Kulish resorted to writing works in Russian throughout his life, but at the same time fruitfully developed the genre system of Ukrainian literature. In his first historical novel "Mikhailo Charnyshenko ili Malorossyia vosemdesiat let nazad" ("Mykhailo Charnyshenko, or Little Russia Eighty Years Ago") P. Kulish, like Sir Walter Scott in the English literature, started to create his own national myth.

The convergentive group comprises writers who use the foreign language of the metropolis while maintaining a national mentality. M. Gogol's prose on Ukrainian subjects (the collections of short stories "Evenings on a Farm near Dikanka", "Mirgorod"), O. Somov's short stories, Russian-language works by G. Kvitka-Osnovyanenko, Ye. Grebinka (the novella "Nezhenskiy polkovnik Zolotarenko" ("The Nezhen Colonel Zolotarenko"), the novel "Tchaikovsky", the collection of short stories "Rasskazy pyriatintsa" ("The Tales of Pyriatyn's Dweller")) are saturated with national images, stereotypes, attitudes that are a reproduction of the Ukrainian character. This group should not be confused with the "Ukrainian school in the Polish literature", the representatives of which are Polish writers of the 19th cent., who appealed to Ukrainian subjects, but mainly to folklore, historical and landscape themes (Michat Czajkowski, Severyn Goszczyński, Michał Grabowski, Bronisław Zaleski, Antoni Malczewski, Tómasz Padúrra, Juliusz Słowacki, etc.). 
Undoubtedly, M. Gogol is a central figure in the convergentive group. One should also mention the theorist of Russian romanticism O. Somov, the predecessor of M. Gogol in winning St. Petersburg's literary commitment. It was O. Somov who presented to the Russian reader the history and folklore of the Ukrainian people in the form of "little Russian wrecks and fables".

Ye. Grebinka, like O. Somov, wrote pieces of fiction about the Ukrainian past, which fit into the then Russian literature. He is also a representative of the so-called "natural school" - the first stage of the Russian realistic literary direction. It should be noted that the author of Russian-language "physiological essays" - perhaps the main genre of this stage - was also G. Kvitka-Osnovyanenko. Ukrainian writers turned to this genre appropriately - in the wake of literary fashion. Literary critics are inclined to believe that in Russian literature this genre was initiated by the authors of the almanac "Our People, Written from Life by the Russians" (1840-1842) edited by Alexander Bashutsky ${ }^{25}$. The writers did not simply "monkey" French or English prototypes, but tried to develop their own concept of depicting life realities, based on the tradition laid down by ethnographic essays by Konstantin Batiushkov, Vladimir Odoevsky and others. However, works that can be attributed to the "physiological essay", appeared earlier - this is, in particular, an essay "The Fair" by G. KvitkaOsnovyanenko, published in 1840 in one of the issues of "Sovremennik" ("The Contemporary").

The biliterary group is represented by a number of names: these include the Ukrainians who launched the historical novel genre in the Russian literature ("Ivan Gosnitsky ..." by V. Narizhny, "Khmelnytsky...", "Nalivayko..." by P. Golota, "Fedyusha Motavilsky..." by I. Kulzhinsky and others). The figure of M. Gogol, whose creativity is crucial for the emergence and development of Russian literature, should also be singled out, so it should also be attributed to the biliterary group.

The creativity of V. Narizhny is important above all because the author, unrecognized for his life's work, is the founder of the classic novel

${ }^{25}$ Кулешов В.И. Натуральная школа в русской литературе XIX века. Москва : Просвещение, 1965. С. 121. 
in the Russian literature ${ }^{26}$. Prohibited by the censorship of the writer's life, the satirical novel "Rossiysky Zhilblaz, ili Pokhozhdeniya knyazya Gavrily Simonovicha Chistyakova" ("A Russian Gil Blas, or The Adventures of knyaz Gavril Simonovich Chistyakov") (1814, 1st full edition - 1938) showed a great influence of the West European picaresque novel in the Russian literature and began the transition to a life-describing realism. Most of his works are Ukrainian-themed - a Bildungsroman "Aristion, ili Perevospitaniye" ("Aristion, or Re-education") (1822), "Bursak" ("The Divinity Student") (1824), the novelettes "Dva Ivana, ili Strast k tyazhbam" ("Two Ivans, or the Passion for Litigation") (1825), "Garkusha, malorossiyskiy razboynik" (“Garkusha, the Little Russian robber”) (1825).

M. Gogol is characterized by a double literary affiliation: without him, it is impossible to construct the Russian literary canon, and at the same time its "ejection" from the Ukrainian literature is quite unjustified. This is due, first of all, to the unambiguous linguistic attitude of the author, who, however, could not silence his own national character and ethnicity. It is in the primary consideration of the cultural context, along with factors such as language, subject matter, ethnic origin or attachment to the territory, as George Grabowicz emphasizes ${ }^{27}$. The borderlines of M. Gogol's creativity are to some extent symptomatic and reflect the complexity of the nationalcultural situation of colonized Ukraine within the Russian Empire.

The assimilative group represents those writers who, despite their genetic affiliation to one ethnic group, belong to language characteristics, education, culture and creativity of another ethnic group ${ }^{28}$. These include, first of all, Antony Pogorelsky, Ivan Bogdanovych, Mykola Gnidych (Hnedych) and writers from Ukrainian families who represent the Ukrainian school in Polish Romanticism (Michał Czajkowski).

${ }^{26}$ Манн Ю. У истоков русского романа // В. Т. Нарежный. Сочинения. В 2-х т. Москва : Худож. лит., 1983. Т. 1 : Российский Жилблаз, или Похождения князя Гаврилы Симоновича Чистякова / Вступ. ст., подгот. текста и примеч. Ю. В. Манна. 1983. C. 14.

${ }^{27}$ Грабович Гр. Українсько-російські літературні взаємини в ХІХ ст.: постановка проблеми // Гр. Грабович. До історії української літератури: Дослідження, есе, полеміка. Київ : Основи, 1997. С. 210-211.

28 Джуанышбеков Н. Типологические группы интеграционной литературы // Літературна компаративістика. Вип. III. Ч. І. Київ : Стилос, 2008. С. 46. 
The grandson of the last Hetman of the Zaporozhian Host Kyrylo Rozumovsky (Kirill Razumovski), Oleksiy Perovsky wrote exclusively in Russian and entered the Russian literature of the 1st half of the 19th century under the pseudonym of Antony Pogorelsky. The writer was a participant of the Arzamas society, a bright recipient of German fantastic prosaic tradition in Russian Romanticism, as well as the author of the novel "Monastyrka" (1830), in which colonial forms of representation of Little Russia and the imperial view of Ukraine in the 1st half of the 19th cent. are visible (more precisely, at that time administrative-territorial entities of the Russian empire - Poltava and Chernihiv provinces) ${ }^{29}$. Antony Pogorelsky "constructed" the identity of the Ukrainian province, giving certain mythological meanings to artistic images. There are special "closed" topoi of the province/city/town/village in the novel. In "Monastyrka" a reader does not find the Ukrainian landscapes, which were the myth basis of "blessed" Little Russia in many works of Ukrainian and Russian writers of the 1 st half of the 19 th cent.

The narrator portrays an unattractive image of Little Russia with its horrible weather, dirty taverns and messy stations where a tired traveller can't finds horses for his cart. In Antony Pogorelsky's novel, the cultural assimilation of the main characters in the educational institutions of the capital of the Russian Empire fundamentally alters their worldviews and cultural values and bears a real threat to the identity of Ukrainians ${ }^{30}$. The disproportionate conditions in which the Ukrainian province and the Russian capital were described in the novel caused the alleged protest. In particular, in his "Essays on the History of New Russian Literature", A. Kirpichnikov mentioned the anonymous letters of Ukrainian readers to the editorial staffs of Russian magazines, which were full of indignation because of slander in relation to Little Russia and biased evaluations of the nobility in "Monastyrka" 31.

${ }^{29}$ Погорельский А. Монастырка // Антоний Погорельский. Двойник: избранные произведения. Киев : Дніпро, 1990. С. 148-323.

${ }^{30}$ Чик Д. Форми протиставлення «центру» і «периферії» у романі «Монастырка» Антонія Погорєльського // Studia methodologica. 2011. № 32. С. 223-225.

31 Кирпичников А. И. Антоний Погорельский, эпизод с истории русского романтизма // А. И. Кирпичников. Очерки по истории новой русской литературы. 2-е изд., дополн. Москва : Книжное дело, 1903. Т. 1. 1903. С. 116-117. 


\section{CONCLUSIONS}

In the article I attempted to revise the canon of Ukrainian literature of the 1st half of the 19th century in light of recent literature studies. By applying the theory of integrative literature to characterize this period, the canon is proposed to include Ukrainian writers who, for various reasons, wrote their works in the language of the metropolis. It should be emphasized that the creativity of one or another writer often does not fit into any one of the groups identified (in particular, M. Gogol). Applied to the 19th century Ukrainian literature in the context of Ukrainian-Russian discourse, the typology changes its configuration depending on the time periods and dominants of historical, cultural and literary processes.

\section{SUMMARY}

In the research the revision of the Ukrainian literature canon of the 1st half of the 19th century is proposed. The Ukrainian literature of the time period is considered as an integrative one with adaptive, differential, convergentive, biliterary, and assimilative typological groups.

It is proved that the research of the 1 st half of the XIX century literature is impossible without taking into account the complex process of the primary formation of the Ukrainian nation, which took place in the colonial circumstances.

\section{REFERENCES}

1. Александрова Г. Глобалізація і нові стратегії в компаративістиці // Українознавчий альманах. 2013. Вип.11. С. 77-79.

2. Андерсон Б. Уявлені спільноти. Міркування щодо походження й поширення націоналізму. Київ : Критика, 2001. 272 с.

3. Ассман Ян. Культурная память: Письмо, память о прошлом и политическая идентичность в высоких культурах древности / пер. с нем. М. М. Сокольской. Москва : Языки славянской культуры, 2004. 368 c.

4. Берков П. Н. История русской комедии XVIII в. Ленинград : Наука, 1977. 392 с. 
5. Беркофф Дж. Б. Чи існує канон українського літературного Бароко? // Український гуманітарний огляд. 2012. Вип. 16-17. C. 9-54.

6. Білецький О. І. Гоголь і українська література // Гоголь i українська література XIX ст. : зб. ст. Київ : Держ. в-во худ. літ., 1954. C. 3-18.

7. Блум Г. Західний канон: книги на тлі епох / пер. 3 англ. під заг. ред. Р. Семківа. Київ : Факт, 2007. 720 с.

8. Борзенко О. I. Сентиментальна “провінція": (Нова українська література на етапі становлення). Харків : Харків. націон. ун-т ім. В. Н. Каразіна, 2006. 322 с.

9. Глотов О. Російська література України: методологія питання // Теорія літератури. Компаративістика. Україністика: зб. наук. праць з нагоди 70-річчя професора Романа Гром'яка // Studia methodologica. 2007. Вип. 19. С. 28-30.

10. Грабович Гр. Семантика котляревщини // Гр. Грабович. До історії української літератури: Дослідження, есе, полеміка. Київ : Основи, 1997. С. 316-332.

11. Грабович Гр. Українсько-російські літературні взаємини в XIX ст.: постановка проблеми // Гр. Грабович. До історії української літератури: Дослідження, есе, полеміка. Київ : Основи, 1997. С. 196-237.

12. Гундорова Т. Микола Гоголь i колоніальний кітч // Гоголезнавчі студії. Ніжин, 2009. Вип. 18. С. 17-40.

13. Джуанышбеков Н. Типологические группы интеграционной литературы // Літературна компаративістика. Вип. III. Ч. І. Київ : Стилос, 2008. С. 39-49.

14. Дзюба I. М. Тарас Шевченко. Життя і творчість. 2-ге вид., доопрац. Київ : Києво-Могилянська академія, 2008. 718 с.

15. Зубков С. Д. Русская проза Г. Ф. Квитки и Е. П. Гребенки в контексте русско-украинских литературных связей. Київ : Наук. думка, 1979. 272 с.

16. Квітка-Основ'яненко Г.Ф. Зібр. творів у 7-ми т. / [ред. колегія : П.М. Федченко, О.І.Гончар, Б. А. Деркач, С. Д. Зубков, Д. В. Чалий]. Київ : Наук. думка, 1978-1981. 
17. Кирпичников А. И. Антоний Погорельский, эпизод с истории русского романтизма // А. И. Кирпичников. Очерки по истории новой русской литературы. 2-е изд., дополн. Москва : Книжное дело, 1903. т. 1. 1903. С. 76-120.

18. Когут 3. Розвиток малоросійської самосвідомості і українське національне будівництво // 3. Когут. Коріння ідентичности. Студії $з$ ранньомодерної і модерної історії України. Київ : Критика, 2004. C. 80-101.

19. Костомаров Н. Две русские народности (Письмо к редактору) // Основа. 1861. № 3. С. 33-80.

20. Кулешов В. И. Натуральная школа в русской литературе XIX века. Москва : Просвещение, 1965. 300 с.

21. Манн Ю. У истоков русского романа // В. Т. Нарежный. Сочинения. В 2-х т. Москва : Худож. лит., 1983. Т. 1 : Российский Жилблаз, или Похождения князя Гаврилы Симоновича Чистякова / Вступ. ст., подгот. текста и примеч. Ю. В. Манна. 1983. C. 5-44.

22. Павлишин М. Історія літератури і здоровий глузд // Історії літератури : збірник статей/ упоряд. О. Галета, Є. Гулевич, 3. Рибчинська (Центр гуманітарних досліджень ЛНУ ім. Івана Франка). Київ : Смолоскип ; Львів : Літопис, 2010. С. 1-31.

23. Погорельский А. Монастырка // Антоний Погорельский. Двойник: избранные произведения. Киев : Дніпро, 1990. С. 148-323.

24. Сомов О. О романтической поэзии: опыт в трех статьях. Санкт-Петербург : В Тип. Имп. Воспитательнаго Дома, 1823. 102 с.

25. Чик Д. Форми протиставлення “центру” і “периферії” у романі "Монастырка" Антонія Погорєльського // Studia methodologica. 2011. № 32. C. 222-226.

26. Шалагінов Б. “Фауст” Й. В. Гете як центр новоєвропейського літературного канону // Б. Шалагінов. Класики і романтики: Штудії 3 історії німецької літератури XVIII-XIX століть. Київ : КиєвоМогилянська академія, 2013. С. 47-57. 
27.Шкандрій М. В обіймах імперії: російська і українська літератури новітньої доби / [пер. П. Таращук]. Київ : Факт, 2004. $496 \mathrm{c.}$

28. Юрчук О. У тіні імперії: українська література у світлі постколоніальної теорії : монографія. Київ : Академія, 2013. 224 с.

\section{Information about the author:}

Chyk D. Ch.,

Doctor of Philological Sciences in Comparative Literature, Associate Professor at the Department of Foreign Languages and their Teaching Methods, Taras Shevchenko Regional Humanitarian Pedagogical Academy of Kremenets 1, Litseynyi L. str., Kremenets, Ternopil Region, 47003, Ukraine 


\section{THE LITURGICAL SONGS IN CREATIVE WORK OF BOHDAN-IGOR ANTONYCH}

\section{Dmytriv I. I.}

\section{INTRODUCTION}

The creative work of Bohdan-Igor Antonych is one of the most significant pages of our literature, it has a genuine originality in the comprehension of artistic reality and exceptional depth in reproducing the specifics of the religious worldview, and yet it is distinguished by genre versatility, a wide palette of poetic means, high level of subjectivity in the poetic interpretation of traditional plots. Given this, the poetical heritage of B.-I. Antonych remains a fertile ground for literary studies. That's why, the "The Great Harmony" collection needs some rethinking, because it is a unique poetic attempt of dipping into the mystery of human existence, the desire to find answers to difficult life questions in the relationship with the Creator.

The use of symbols, especially religious ones is characterized for the creative work of B.-I. Antonych. Among Christian symbolism, liturgical symbolism plays an important role, however the Liturgy, the basis of the Christian life, is inalienably connected with the Scripture. According to Christian teaching, there are two ways to get acquainted with God: the first is in the Eucharist, which is performed at the Liturgy; the second is to receive the Word of God. There is a close connection between the Bible and the Service of God, since the Liturgy is largely constructed on the Scripture expressions.

The artistic reception of liturgical works is closely connected with the fact that music and singing are important means for achieving the mystical state of unity between a man and God in the works of B.-I. Antonych. In his poetry musical images are symbolized, are carriedan important semantic loading (for example, a harp, bell, violin). At the genre level, the author often uses psalms, hymns, songs; biblical stylization, allusions from the Scripture and famous liturgical works are typical for him. 
It is noticeable that some works of B.-I. Antonych are laid on music, including "Mater Dolorosa", "Christmas" ("God was born on a sleigh"), "Christmas carol” ("Carpenters hews sleighs from silver”). So, to express the ecstatic outliving of God, the poet sometimes not enough words, then music comes to the help, which is able to touch the subtlest strings of the soul and tunethe person for acceptance of mercy.

\section{Reception of Divine Liturgy in collection "The Great Harmony" by Bohdan-Igor Antonych}

Much of the works that have been included in collection "The Great Harmony" by Bohdan-Igor Antonych are poetic replaying of the Divine Liturgy. For example, works "Kyrie Eleison", "Gloria in Excelsis", "Credo", "Sanctus", "Agnus Dei" have identical names with parts of Liturgy of the Latin rite, and poems"Veni Sancte Spiritus", "Deus Magificus", "Te Deum Laudamus", "Veni Creator", "Confiteror", "Mater Dolorosa", "Mater Gloriosa" and "Salve Regina" are ideologically related to the hymnographic Christian tradition. It should be noted that the Divine Liturgy of both the Eastern and the Western Rites is deeply rooted in the Scripture, howeverthe psalms are actively used in it, the fragments from the Gospels and the Epistles of the Apostles are read, not to mention the spiritual connection between what is written in the Scripture and is performed at the Liturgy.

Alexander Schmemann points out that the concepts "symbols" and "symbolism"have become practically synonyms with the Byzantine Liturgy, because almost all liturgists understand the Divine Liturgy as a symbolic representation of the life of Jesus Christ, from birth in Bethlehem to the glorious ascension into Heaven ${ }^{1}$. The quintessence of the Christian Liturgy is the Eucharist, that is, Thanksgiving. Strictly speaking, the motive of thanksgiving, blessing, worship, the glorification of God is throughout in "The Great Harmony". Iryna Betko believes that in some metaphorical sense, "The Great Harmony" can be identified as a kind of open prayer".

${ }^{1}$ Шмеман А. Символы и символизм византийской литургии: Литургические символы и их богословское истолкование. Синопсис. 2001. № 4/5. Ст. 74.

2 Бетко І. Осмислення нумінозного досвіду в поезії Богдана-Ігоря Антонича. Бетко I. Украӥнська релігійно-філософська поезія. Етапи розвитку. Katowice: Wydawnictwo Uniwersytetu Śląskiego, 2003. Ст. 200. 
Researcher V. Lepakhin, considering prayer as a verbal icon, gives it all the features of iconic image, namely: ontology, antinomy, canonicity, symbolism, synthetic and synergistic. The ontology is that the believer does not doubt about the presence of God, so prayer preserves the prototype of God. Antinomy: prayer preserves contradictions between two concepts, phenomena that mutually exclude one another. From the very beginning the sinful personappeals to the sinless Absolute, and by that appeal he brings himself nearer to God. Canonicity means that prayer is created according to a certain rule given to humanity by Jesus Christ in the doctrine of prayer in the Sermon on the Mount. The symbolism is realized in the fact that Christ, who created the doctrine that became the law of life for men, is the symbol of faith for Christians; prayer is also part of this symbol of faith. Synthetic - in prayer, the Earth is united with the Upper Powers, during prayer everything else becomes non-essential to the believer. Synergistic - the prayer word becomes an accumulator of energy state, a hidden factor of action, a symbol of synergy. Through prayer, the body's reaction andits energy increases so much that sometimes the believer feels exhausted after this action, as if purified from $\mathrm{bad}^{3}$.

Theologians distinguish in the prayers the three stages of mastering the sacrum: the first is reading, worship, "cheerfulness"; the second is where the physical and spiritual appear as equivalent; the third is the action of prayer without words, without worship, even without thinking. Prayer is a true spiritual life in processual and action. Therefore, literary prayer must also accumulate spiritual effort. Prayer is a word of not indifferent person, a word that anyone can say, its emotional and spiritual accusation is also preserved in literary texts ${ }^{4}$.

In Christianity, the following basic types of prayers are distinguished: praise, request, gratitude, repentance prayer. In the New Testament, a similar division was mentioned: "[...] I exhort, that, first of all, supplications, prayers, intercessions, and giving of thanks, be made for all men" (1 Tim. 2, 1).

\footnotetext{
3 Лєпахін В. Ікона та іконічність. Львів: Свічадо, 2001. Ст. 145.

${ }^{4}$ Бовсунівська Т. Молитва як літературний жанр. Дивослово. 2003. № 7. Ст. 3.
} 
This thematic differentiation of prayers also concerns to the literary tradition where it is actually preserved. T. Bovsunivska adds "prayer to prayer" as a kind of literary formation, a modification of the liturgical nature of prayer ${ }^{5}$. In "The Great Harmony" there is a poem "Prayer" where the author praises the prayer as follows:

A mortal's prayer is like smoke,

it circles above a village like a white swan,

it blows along the crystal sky

like a curly-haired golden stem [...].

A mortal's prayer is like an eagle,

above the clouds it flies out from the earth's threshold,

and begins to quiver like a quail:

it catches sight of the fiery face of $\operatorname{God}^{6}$.

Prayers of praise of God and request aredominated in B.-I. Antonych. But the request is not for small earthly things, but for the gift of faith, for the gifts of the Holy Spirit, for the harmony of the soul. Such poems as "Deus Magnificus", "Magnificat", "Te Deum laudamus", "Te Deum laudamus, II" are an artistic illustration of the prayers-blessing. In these works, the author praises the Lord, praises His greatness, and admires His omnipotence and omnipresence. Each line of the poem testifies to the poet's faith in the only God the Father, the Almighty, the Creator of heaven and earth, of all things visible and invisible.

"A gratitude prayer, writes Fr. Alexander Men, is the most beautiful and purest among prayers. She seeks nothing, asks nothing, but only filled with joyful awareness of the mercy of God poured out on a person. For everything: for the eyes that see the sun and the beauty of the world; for ears that hear the harmony of sounds and the Word of God; for a mind that comprehends secrets; for a heart that is able to love - a person thanks for all of this ${ }^{7}$.

${ }^{5}$ Бовсунівська Т. Молитва як літературний жанр. Дивослово. 2003. № 7. Ст. 3.

6 Антонич Б. І. Повне зібрання творів / Передмова Миколи Ільницького; Упорядкування і коментарі Данила Ільницького. Львів: Літопис, 2009. Ст. 97-98.

${ }_{7}$ Мень А. В. Таинство, Слово и Образ. Православное богослужение. Москва, 2001.Ст. 54. 
If we talk about the liturgical aspect of Antonych's poetry, it should be notedthat a noticeable feature of the poems mentioned above is their rooting in the psalms and other liturgical texts. The liturgical antiphons are the same "fragments of the psalms that have been preserved from the Jewish synagogue worship and contain, except the prayerfuland entreating, more praiseworthy and glorious element. The psalms are used not only in the Liturgy, but also as a part of all other worships"8. E. Ronkey thinks of the place of psalms in the prayer tradition: "Let's try to imagine the birth of the psalms. People prayed in a variety of situations, in joy and sorrow, after victory and on the brink of death, in the dark valleys and in the face of beauty, among the dust of the ways and incense of the temples: King (David) before the war and after sin, the shepherd, the poet, the sick, the Levite. And they all prayed so well, in such beautiful words, that God said, these words become mine, and I give them to people as my words, and they will give them to me as their words. Human words, becoming the words of God, become human words again. The Psalm is the word of man and the word of God, which are united once and for ever [...] Pray the psalms is more than religious thought"".

Iryna Betko notes that in the Ukrainian poetic tradition the Psalter's reception highlights a number of literary and artistic regularities. Thus, the correlation of proper imitative and specific author's factors in psalter's innovations determines the belonging of one or another of them to a certain receptive type. The researcher numbers five of these types: 1) the group of contexts of the first receptive type envisages the fullest possible reproduction of the features of the original by means of the recipient's language, except that super-task, the translator has no other purpose, as a rule; 2 ) the second receptive type is characterized by the preservation of all the compositional-content units of the original as the basis, which is updated by a fundamentally new artistic content, mainly through stylistic and versification decisions and implication; 3) in the third group, the interpreted original source,the reference to which is often contained in the

${ }^{8}$ Соловій М., о. Божественна Літургія: Історія - розвиток - пояснення. Львів: Свічадо, 1999. Ст. 221.

${ }^{9}$ Ронкі Е. Закоханий і здивований Бог / Пер. з італ. К. Зінченко. Львів: Свічадо, 2015. Ст. 36-37. 
epigraph, is unmistakably read, but the new creation is completely independent of its prototype in all its formal and semantic features; 4) this group is a throughoutpsalter's stylizations that, at external similarity, donot foresee compulsory internal sense connections with specific psalms; 5) it is a group of poems that, without any external references to the Psalter, is deeply linked to it through hiddenquotation, paraphrase, etc. ${ }^{10}$.

B.-I. Antonych's psalms are undoubtedly new creatures, although there are hints at the original source. However, it should be noted that the definition of "psalm" is not strictly genre, but rather indicates the sourcefirst-basis of new creation. The Psalter itself, whose sacred content is defined as an inspired conversation of the human heart with God, is an inter-genre association from a literary point of view. By genre content, the psalms are divided into hymns, cries, prayers, wisdoms, prophecies, invective, etc."11.

The poem "Te Deum laudamus", which is ideologically linked to both the Psalter and the Liturgy, has a significant place in "The Great Harmony".

The earth is a golden-stringed harp of Your glory,

day and night - a prayer of longing and hope,

the sky is the ultimate human goal,

all together - the grand harmony glorifies $\mathrm{You}^{12}$.

This poem is analogous to the hymn "Holy, holy, holy, is the Lord of armies: all the earth is full of his glory", taken from the vision of the prophet Isaiah, who saw heaven and God, to whom angels sang praise songs (Isa. 6, 1-5). In the quoted poemit is also traced the features of the 150 th Psalm: "Give praise to God in his holy place: give him praise in the heaven of his power. Give him praise for his acts of power: give him praise in the measure of his great strength. Give him praise with the sound of the horn: give him praise with corded instruments of music. [...] Let everything which has breath give praise to the Lord. Let the Lord be praised!" (Ps. 150, 1-5). Besides that, "Te Deum laudamus" has common features with the song of

10 Бетко I. Біблійні сюжети і мотиви в українській поезії XIX - початку XX століття. ZielonaGyra - Kijyw, 1999. Ст. 115-116.

11 Бетко I. Біблійні сюжети і мотиви в українській поезії XIX - початку XX століття. ZielonaGyra - Kijyw, 1999. Ст. 117.

12 Антонич Б. І. Повне зібрання творів / Передмова Миколи Ільницького; Упорядкування і коментарі Данила Ільницького. Львів: Літопис, 2009. Ст. 92. 
St. Ambrose, Bp. Mediolanskiy "We praise You, God": "We praise You, God, we recognize You, Lord. All the earth glorifiesYou, Eternal Father. All the angels to You, the heavens and all the powers to You, cherubim and seraphim sing to You with incessant voices: Holy, holy, holy Lord God of armies! $!^{13}$. Both the psalms and the song of St. Ambrose was, without doubt, known to B.-I. Antonych and became an organic part of his poetry.

Blessings is an integral and important part of worship: "Glory to You, our God, Glory to You" or "Glory to You, Lord, Glory to You", "Glory to God in the highest, and peace on earth, and pleasantness in people"."Through blessings, glorification of Love, Wisdom, Mercy of the Lord during worship, - emphasizes D. Bolharskiy, -a person joins the Divine life, thereby healing his soul damaged by sin and passions, stands on a grace way of salvation and, if he lives without breaking the commandments of God, in the spirit of Christian love, then has the opportunity to imitate eternal life" ${ }^{\text {.14 }}$.

A stylistic figure such as anaphora promotes the imagery and rhythm of the biblical text, and the closer unification of its components. In the Psalms of King David, it is quite common, in the religious poetry of B.-I. Antonych it also has an active use. The poem "Te Deum laudamus, II" will serve as an illustration of the artistic use of this figure:

For You the sea plays a radiant, spirited psalm,

for You the wind sings echoing, thunderous songs,

for You the fierce storm disturbs the bottom of the sea,

for You the grass stirs in a silken whisper ${ }^{15}$.

Sometimes the poet skillfully combines anaphora with epiphora:

When you call in the night - He is there,

when you call for help - He is there,

when you search - He is there,

you already have Him for He is within ${ }^{16}$.

${ }^{13}$ Прийдіте поклонімся: Молитовник. 5-те вид.випр. Львів: Свічадо, 2007. Ст. 887.

${ }^{14}$ Болгарський Д. До проблеми розуміння православного богослужебного співу. Наукові записки: Збірник наукових статей Національного педагогічного університету ім. М. Драгоманова. Вип. 40. Київ, 2001. Ст. 74.

15 Антонич Б. І. Повне зібрання творів / Передмова Миколи Ільницького; Упорядкування і коментарі Данила Ільницького. Львів: Літопис, 2009. Ст. 112.

16 Антонич Б. І. Повне зібрання творів / Передмова Миколи Ільницького; Упорядкування і коментарі Данила Ільницького. Львів: Літопис, 2009. Ст. 93. 
The frequent use of the anaphora by the poet emphasizes the sacred dimension of the poem: the repetition of the word witnesses about its importance, and so directs, raises the thoughts and feelings of the person upwards, to the transcendent ${ }^{17}$.

Is there anything special and artistic in the request prayers by which the lyrical hero of the collection appeals to the Lord? The answer to this can be found in the poem "Kyrie elejson" ("Lord Have Mercy!").

In the poem of the same name by B.-I. Antonych the appeal "Lord Have Mercy!" sounds refrain. "The writers also use the repetition of prayer as a principle of sacred worldview in any religion. Sometimes the fragmentary reproduction of prayer promotes "prayerfulness" as a worldview" $" 18$.

I lift up my hands in mute ecstasy,

Darkened eyes shine with it.

Give sweet utterance to my lips for You.

Lord have mercy

from the silence of night. [...]

I tear the unknown, opaque distance with my eyes,

my soul again is already peaceful and healthy,

Give creative, free, ripe language to my lips!

Lord have mercy

from the helplessness of the word ${ }^{19}$.

$\mathrm{H}$. Tokman remarks that the work is caught by one emotional state that can be called religious ecstasy. The development of ecstatic feelings in the work concerns the response of a person to the experience of the Holy, the hero changes himself during his stay in ecstasy. The poet asks God for the gift of the word, opposing it to the silence of the night, the brand of separation, the darkness of sight, the feebleness of the word... The artist wants to escape from the captivity of alienation from the essential Being,

${ }^{17}$ Papla E. Muzyczna Liturgia Bohdana Ihora Antonycza (na podstawie cyklu "Wielka Harmonia") Ukraina. Między językiem a kulturą. Studia Ruthenica Crakoviensia: 1. I Pod. red. B. Zienkiewicz-Tomanek, A. Falowskiego. Kraków: Universitas, 2003. St. 375.

${ }^{18}$ Бовсунівська Т. Молитва як літературний жанр. Дивослово. 2003. № 7. Ст. 3.

19 Антонич Б. І. Повне зібрання творів / Передмова Миколи Ільницького; Упорядкування і коментарі Данила Ільницького. Львів: Літопис, 2009. Ст. 112-113. 
to overcome this alienation by his poetic word, he prays to God - and feels how God helps him: the soul "becomes calm and healthy", he "tears"with hiseyes, and eventually "breaks off" the dark opaque distance. The poet's desire for the inspired word, that is dear to God, to the sharp, lightlywinged, creative, free, mature language, was probably heard, because the hero becomes stronger in spirit, becomes more courageous" ${ }^{\prime 20}$. We interpret this Antonych's poem after H. Tokman as a figurative expression of what P. Tillich called "an ecstatic experience of spiritual power".

In the liturgical practice, the prayer "Lord Have Mercy!" is often used because it "contains all the anguish of a person for God" ${ }^{\prime 21}$ and the person's will is entirely subordinated to God's will. By its roots the prayer"Lord Have Mercy!"goes back to the Old Testament, but its complete consummation gets in the Gospel: the lepers, aspiring clearing, called Jesus Christ, "Jesus, Teacher, have mercy on us," a blind man who wished to see and felt the presence of Christ, said, "Jesus, Son of David, have mercy on me". Later these lines formed the basis of the widespread in the Eastern Christian tradition of Jesus' prayer, "the greatness of which is discovered even by its construction, which consists of two parts: the first one, that is," Lord Jesus Christ, the Son of God, "leads the mind into the story of life of Jesus Christ, or, as the Holy Fathers speaks about, "contains the whole Gospel", and the second part, that is, "have mercy on me sinful", depicts the story of our powerlessness and sinfulness ${ }^{22}$.

Metropolitan Antony Surozkiy notices in his thoughts on prayer that the word "have mercy" is the Greek word "eleison", which comes from the same root as "eleon", which means "oil". In the Old and New Testaments, we meet this notion in a series of parables and events that allow us to fully understand the meaning of this word. This is also the book of Genesis, when, after the flood, the dove returns to Noah with an olive branch, which symbolizes about the cessation of God's anger. In the parable of the merciful Samaritan, oil is used to relieve pain and heal wounds.

${ }^{20}$ Токмань Г. Збірка Б.-І. Антонича “Велика гармонія” у діалозі з екзистенціальним богослов’ям. Слово $i$ час. 2002. № 12. Ст. 51.

${ }^{21}$ Соловій М., о. Божественна Літургія: Історія - розвиток - пояснення. Львів: Свічадо, 1999. Ст. 215.

${ }^{22}$ Щирі розповіді Прочанина своєму духовному отцеві / Пер. 3 рос. Д. Кічі. Львів: Свічадо, 2005. Ст. $124-125$. 
So, "mercy" and "have mercy" are words of the same root that express tenderness, that's why when we ask God to have mercy on us, it is not only to get rid of His anger, we ask for love $\mathrm{e}^{23}$. The similar reflections isfound in "The Honest Stories of the Pilgrim to His Spiritual Father": "It is impossible out of this word ("have mercy on me") to express the desire and request of a poor, sinful and submissive soulwiser, clearer and more essential. No other expression would be as exhaustive and complete as this one. For example, if you said, "Forgive me!", "Forgive sins!", "Forgive iniquity!", "Make up for my crimes!"- then all that would only express one request about theliberation from punishment.But the expression"have mercy on me" means not only caused by fear desire to ask for forgiveness, but it also contains a true cry of son's love, hoping for the mercy of God and submissively admitting his powerlessness. A cry for pardon, not only for the forgiveness of sins, but also for the outpouring of mercy, manifested in the gift of spiritual power from God, a spirit that strengthens us in the fight against temptation and helps to conquer the sinful inclination",24.

Usually, after a heart is broken by repentant prayer, joy and a desire to glorify God come. This regularity is observed in "The Great Harmony" by B.-I. Antonych, where the request-repentant tone of the poem "Kyrie elejson" naturally goes into praising - "Magnificat". The poet's heart aspires to sing to God "a commendable psalm", "a mighty song", "a pure song", as the psalmist once called: "The Lord of armies is with us; the God of Jacob is our high tower" (Ps. 46, 7), "Sing Him a new song" (Ps. 33, 3), "I will make a new song to you, o God" (Ps. 144, 9).

\section{Sacred musical symbols in the creative work of Bohdan-Igor Antonych}

Music has always made a significant influence on person's spiritual life. "The experience of prayerful worship embodied in songs is anevidence of the spirit of the highest Mind, in which there are the rhythm,

${ }^{23}$ Сурожский А., митр. Школа молитвы. Клин: Христианская жизнь. С. 79-80.

${ }^{24}$ Щирі розповіді Прочанина своєму духовному отцеві / Пер. $з$ рос. Д. Кічі. Львів: Свічадо, 2005. Ст. 125. 
breath, and life of the Kingdom of Heaven" ${ }^{25}$. E. Ronki generally believes that "only the music of poetry and the poetry of music can establish a connection with God and reality [...] In Scripture, it is not enough to reflect on God or speak about Him - you also need to sing. Singing is more than a simple recitative. Singing is more than a voice and a sound, because it enlists music, artistic experience of beauty, culture and history of the people [...] In prayer, the song enlists the body, the world and history. The poetry of music is added to the music of poetry [...] Christ presents himself, the Word is presented through beauty in music and poetry" 26 .

In ancient times, people expressed their aspiration for the Divine through word and music. There are several vivid examples in the Old Testament books to confirm this view. For example, when the evil spirit tormented Saul, David played on harps for the king and the spirit retreated. Also, when the prophet Elisha wanted to ask something from God, he ordered to bring the harper. "But now, get me a player of music, and it will come about that while the man is playing, the hand of the Lord will come on me and I will give you the word of the Lord: and they got a player of music, and while the man was playing, the hand of the Lord was on him" (2 Kings 3, 15). During the reign of David, over 4,000 musicians played and sang in the temple allday and night (1 Chron. 9, 33; 23, 5). But the fullest meaning of spiritual singing is represented in the psalms which convey the state of the soul when it is filled with the Lord, however only a person filled with the Spirit of God can sing for the Creator from the fullness of his heart: "and will make a song of praise to your name" (Ps. 18, 50), "I will make a song, truly I will make a song of praise to the Lord" (Ps. 27, 6), "For God is the King of all the earth; make songs of praise with knowledge" (Ps. 47, 7), "I will make songs to the Lord all my life; I will make melody to my God while I have my being” (Ps. 104, 33), and others. In the New Testament, St. Ap. Paul also calls upon Christians to say among themselves "psalms and hymns and spiritual songs"

${ }^{25}$ Болгарський Д. До проблеми розуміння православного богослужебного співу. Наукові записки: Збірник наукових статей Національного педагогічного університету ім. М. Драгоманова. Вип. 40. Київ, 2001. Ст. 74.

${ }^{26}$ Ронкі Е. Закоханий і здивований Бог / Пер. з італ. К. Зінченко. Львів: Свічадо, 2015. Ст. 33-38. 
(Eph. 5,19). Metropolitan Andrew Sheptytskiy, remembering the expression of the Holy Fathers"He who sings, he prays doubly", rightly called singing "a wonderful symbol of prayer": "Sung prayer corresponds to human nature and the natural debts of a person against the Most High [...] in singing, the person, during her life who destroys and torments byincessant disorder and disharmony, internal struggle and external blows, finds what is the ideal of life, that is, the order and harmony"27. These words of Metropolitan Andrew are the suitable key to the reading of collection "The Great Harmony" by B.-I. Antonych.

The name itself "The Great Harmony" is an original key to the interpretation of the collection, because the concept "harmony" coordination, "harmonious" - is dominant in it, is repeated in 12 poems, organizes a figurative system that allows you to consider it as a metaimage $^{28}$. The thought that the world has a musical nature was extremely close to Antonych. The Christian God is the highest harmony, the tuning fork to which poets "tune" other spheres of the musical universe. God, person and nature are united in the only one chord, in the only one musical rhythm ${ }^{29}$ :

In a heart wrapped in the scarves of quiet peace,

melodious, harmonious is every tone.

The distance echoes with just barely audible harps,

wind tunes the night with the tuning fork of God. [...]

Let us listen to the great concert in the evening as

God places his hands on the piano of the world ${ }^{30}$.

In the limit of his spiritual growth, the poet realizes that "it is necessary a little for happiness: harmony" ("Amen"), "harmony in your heart - you do not need anything more" ("Naivety"); in the poem "Litania"

${ }^{27}$ Шептицький А., митр. Про церковний спів (Декрет Собору, читаний дня 25 квітня 1941 р. ст. ст.). Письма-послання Митрополита Андрея Шептицького, ЧСВВ, з часів німеиької окупації. Йорктон, Саск. (Канада), 1969. Ч. 2. Ст. 56-57.

${ }^{28}$ Якубчак Н. Поетика ліричного циклу Б.-І. Антонича. Наукові записки. Том 48. Філологічні науки. Київ: Видавничий дім “Києво-Могилянська академія”, 2005. Ст. 28.

${ }^{29}$ Papla E. Muzyczna Liturgia Bohdana Ihora Antonycza (na podstawie cyklu "Wielka Harmonia") Ukraina. Między językiem a kultura. Studia Ruthenica Crakoviensia: 1. I Pod. red. B. Zienkiewicz-Tomanek, A. Falowskiego. Kraków: Universitas, 2003. St. 377.

30 Антонич Б. І. Повне зібрання творів / Передмова Миколи Ільницького; Упорядкування і коментарі Данила Ільницького. Львів: Літопис, 2009. Ст. 86. 
"harmony of the soul" is identified with the caress of faith. B.-I. Antonych comes to the important recognition that the highest harmony is God:

He gives melody to every thing.

He is harmony, He is a musical chord,

He is the tuning fork tuning your heart,

He is Perfect, Majestic Sound ${ }^{31}$.

In the quotations above, God is not only the source of the harmony of the human heart, but also the cosmic harmony, because"He gives melody to every thing" and that's why the collection is called not simply "harmony" but "The Great Harmony". In the lines of the poem "Deus Magnificus" the poet skillfully weaves several musical terms that are closely connected to each other in music, and in the poetic context they become expressive and imaginative instruments for signifying the Lord. The poet was not confined to the embodiment of the general interpretation of "harmony", but penetrated into the deeper, special meanings and associated them with the various states of the human soul in the process of spiritual struggle, adjusting relationships with the Creator. B.-I. Antonych also calls God a musical chord, because the Creator brought everything from non-existence to existence, gave order where chaos reigned, called every creature to life in perfection, "in wisdom you have made them all" (Ps. 103, 24). However, with the creation of the world, the role of God is not completed, because He not only gives life, but also supports it, thinks through everything in the smallest details. That's why it is entirely justified in this context that B.-I. Antonych calls God "the tuning fork tuning your heart". Why the heart? Because in the Bible the heart marks, basically, the spiritual essence of the human personality. The very heart makes the spiritual decision inattitude to God: it chooses to believe in Him or disobedience to Him. So B.-I. Antonych, according to Christian tradition, perceives the world and life in it as a perfect act of creation, in which there is no place for chaos and disharmony. They appear only when a person voluntarily and consciously breaks off his connection with the Creator,

31 Антонич Б. І. Повне зібрання творів / Передмова Миколи Ільницького; Упорядкування і коментарі Данила Ільницького. Львів: Літопис, 2009. Ст. 93. 
or when he is in a state of intensified spiritual struggle. Thus, in the poem "Veni Creator" the poet is aware of himself in enharmonic contrast to the cosmic harmony of the universe:

You are the chord of cosmic harmony all around,

I am enharmonic - forced to struggle among the waves:

and when my weak soul should fall downward,

muffle the dissonance and smite a helpless soul with thunder ${ }^{32}$.

The loss of mercy, anxiety, incoordination in the soul of the lyric hero, the intense processes of spiritual struggle are associated in B.-I. Anthonych with dissonance and enharmony. Such states can be overcome only with the belief that the Lord, as a perfect harmony, will fill up with Himself the human "enharmony" by the power of the Holy Spirit, as if by a fiery sword, He would cut through the tempter's shackles, absorb the dissonance of the soul, and fill it with the light sound. The Mother of God, to whom the poet appeals in the poem "Ave Maria", is also empowered to "to calm the enharmony":

Fly to me, Immaculate Virgin, quietly stand above a poor heart,

With your hand halt the enharmony of this trembling. [...]

Soar and bring a healing cure in a hard struggle,

calm the enharmonic gnashing of the harp of the heart ${ }^{33}$.

Besides the concepts "harmony", "chord", "enharmony", "dissonance", "melody", there are also other musical terms in "The Great Harmony": "strings", "concert", "tuning fork", "harp", "lute", "lyre", "violin","piano","bells".

The "harp", which has a rich sacred symbolism - an attribute of King David and the angels' choirs, deserves a special attention, however it is known that the psalms were accompanied by playing the harp. The author chose the epithets "gold-stringed", "million-stringed" to the harp. "May I become your harp," the lyric hero appeals to the Lord. Thus, both in the Christian tradition and in the works of Antonych, the harp has at first "praiseworthy" purpose. However, Antonych's harp sounds not only for

32 Антонич Б. I. Повне зібрання творів / Передмова Миколи Ільницького; Упорядкування і коментарі Данила Ільницького. Львів: Літопис, 2009. Ст. 101.

33 Антонич Б. І. Повне зібрання творів / Передмова Миколи Ільницького; Упорядкування і коментарі Данила Ільницького. Львів: Літопис, 2009. Ст. 101. 
the glorification of God the Father, but in "Mater Gloriosa" it accompanies a prayer-glorifying in honor of the Mother of God:

Play, harps, play, lyres, play lutes, play zitherns,

pour out joy, wash away cares, shroud grief with the mantle of spring.

Let the silver-waved, tiny-grained river beds abundantly splash,

fragrant roses and lustrous pearls of the Lord in golden rain from the heavens ${ }^{34}$.

The image-symbol of the harps also has a deep symbolic content, which we will try to discover with E. Ronki. In Psalm 49 we read: "Give attention to this, all you peoples; let your ears be open, all you who are living in the world [...] From my mouth will come words of wisdom; and in the thoughts of my heart will be knowledge. I will put my teaching into a story; I will make my dark sayings clear with music" (Ps. 49, 2-5). That's why, in order to the psalmist declare something important, he does not have enough heart feeling, it is not enough to simply explain this mysterious parable of life - he appeals for help to the music and poetry. For his revelation, he uses harps - as if they were a tool for understanding God and being. The psalmist's harps catches somewhat mysterious, but this is not due to rational concepts - a beauty, that gives birth to astonishment, emotion, capture and feeling, acts here [...] Fighting the closeness of the mystery and fighting the closeness of God for the sake of His appearance, iscarried out in various ways: Jacob fights physically near the ford of Yabbok, Elijah fights with the knife and the fire of the word, Moses with stone tablets, the psalmist with scream and harps, poetry and music. A sacrament explained by the harps ceases to be a mystery, becoming a sensuousexperience, a preface to the theological aesthetics. Thus, God is changed from amystery and a problem into an experience, becoming in the center of being as a song in which the body and spirit are united $^{35}$. So, B.-I. Antonych writes:

I want to play for Him,

to strum the dulcimer with my hand.

34 Антонич Б. І. Повне зібрання творів / Передмова Миколи Ільницького; Упорядкування і коментарі Данила Ільницького. Львів: Літопис, 2009. Ст. 110.

${ }^{35}$ Ронкі Е. Закоханий і здивований Бог / Пер. з італ. К. Зінченко. Львів: Свічадо, 2015. Ст. 32-35. 
A hundred strings, like silver grating,

with which the cedar is strung ${ }^{36}$.

In the poem "The Resurrection", the bell is the image-symbol that invokes the prayer and accompanies it. This is the resurrection and welcoming bell, it impels the whole universe to worship the Resurrected Christ:

Bells peal silkily, brilliantly, baroquely,

bells peal, the entire earth rushes to give greeting,

bells peal silkily, they awaken the Sun's Word,

bells peal, for my soul is rising ${ }^{37}$.

The bell is "a musical sermon, it informs of belief, of a life lit up by its light, awakens a sleepy conscience" ${ }^{, 3}$. However, the bell symbol is only an original "bridge" to the mega-symbol of this work - the "Sunny Word", that is, the Resurrected Christ. The lyrical hero has throughout personal, not just a ritualistic perception of the greatest Christian holiday, because "my soul is resurrected", just like in the poem"Glory in the Highest""Today the Lord was born in the stream of my heart" 39 .

In B.-I. Antonych there is also present the ancient Christian motive, where a person is an instrument in the hands of God:

Sing, my soul, an immaculate song to the Lord,

O be joyful, o rejoice!

Point Your path to ecstatic eyes,

let me become Your harp ${ }^{40}$.

The lyrical hero entreats to become a harp in the hands of God, that is, he asks the Lord's hand to touch the gentle strings of his soul, because only by doing God's will a person can fully reveal himself to the world, in the Antonych's comprehending - to "sound". Researcher Iryna Betko remarks

36 Антонич Б. І. Повне зібрання творів / Передмова Миколи Ільницького; Упорядкування і коментарі Данила Ільницького. Львів: Літопис, 2009. Ст. 97.

37 Антонич Б. І. Повне зібрання творів / Передмова Миколи Ільницького; Упорядкування і коментарі Данила Ільницького. Львів: Літопис, 2009. Ст. 95.

${ }^{38}$ Мень А. В. Таинство, Слово и Образ. Православное богослужение. Москва, 2001. Ст. 14.

39 Антонич Б. І. Повне зібрання творів / Передмова Миколи Ільницького; Упорядкування і коментарі Данила Ільницького. Львів: Літопис, 2009. Ст. 88.

40 Антонич Б. І. Повне зібрання творів / Передмова Миколи Ільницького; Упорядкування і коментарі Данила Ільницького. Львів: Літопис, 2009. Ст. 113. 
that the image-symbol of the prophets' harp is a capacious embodiment of poetic creative work ${ }^{41}$. Through the act of creation the Universe B.I. Antonych tries to understand the purpose of the artist, who, likening himself toGod,also becomes the creator of a new reality.

\section{CONCLUSIONS}

The collection of religious poetry "The Great Harmony" by BohdanIgor Antonych is distinguishes itself by the originality of artistic rethinking of biblical and liturgical texts. Most of the poems of B.-I. Antonych, which are the part of "The Great Harmony", is the stylization of separate prayers ("Ut in omnibus glorificetur Deus" ("That in all things God may be Glorified"), "Veni Sancte Spiritus!", “Come, Holy Spirit!", “Amen", "Te Deum laudamus I, II" ("We Praise Thee, O Lord I, II"),"Praise be to God",'Salve Regina!" ("Hail, Holy Queen!”), "Kyrie elejson!” ("Lord Have Mercy!"). They are related in genre to the psalms, which in B.-I. Antonych are undoubtedly new creatures. They are different in tonality, but this is mostly prayers of God's glorification, in which the lyrical hero is admired by the omnipotence of God the Father, his majestic presence in the Universe, the humility of the Son of God and the wealth of the gifts of the Holy Spirit. In the collection an important place is given to prayer, in which the author asks God for heavenly and earthly goods, but most of all, for harmony in the heart, and around this concept the author forms a whole constellation of musical terms.

The keyword "harmony" is associated with "chord", "enharmony", various forms of "song" and "singing". "Strings", "concert", "tuning fork", as well as the names of musical instruments: "harp", "lute", "lyre", "violin", "piano" and "bells", also belongsto this semantic field. The harp, which is an important sacred symbol, since the psalms were accompanied by playing the harp, deserves special attention. The author chose the epithets of polyphonic sound - "gold-stringed", "million-stringed" to the harp."May I become your harp," the lyric hero appeals to the Lordin the poem"Magnificat".

41 Бетко I. Біблійні сюжети і мотиви в українській поезії XIX - початку XX століття. ZielonaGyra - Kijyw, 1999. С. 69. 
In general, it can be affirmed that "The Great Harmony" is one great prayer "as a process of personal, intimate, secret communication of the believer with God; as a sincere and frank expression of your feelings to the highest being in the world; as a purification of thought from everything secondary and outside; as a reverent dissolutionof your "I" in the object of worship"42.

\section{SUMMARY}

Much of the works that have been included in collection "The Great Harmony" by Bohdan-Igor Antonych are poetic replaying of the Divine Liturgy.For example, works "Kyrie Eleison", "Gloria in Excelsis", "Credo", "Sanctus", "Agnus Dei" have identical names with parts of Liturgy of the Latin rite, and poems "Veni Sancte Spiritus", "Deus Magificus", "Te Deum Laudamus", "Veni Creator", "Confiteror", "Mater Dolorosa", "Mater Gloriosa" and "Salve Regina" are ideologically related to the hymnographic Christian tradition.

The collection "The Great Harmony" is named asoriginal prayer of the poet, in which the motives of glorifying God and request, but request not for small earth's things, but for the gift of faith, for the gifts of the Holy Spirit, for the harmony of the soul, are dominated. If we talk about the liturgical aspect of Antonych's poetry, it should be noted that a noticeable feature of the poems mentioned above is their rooting in the psalms and other liturgical texts. In "The Great Harmony" the poet is often uses anaphora, epiphora, refrain and so on. At the genre level, the author uses psalms, hymns, songs, in his works there are biblical stylizations, allusions from the Scripture and famous liturgical works.

Both in the Eastern and in the Western rites, the Divine Liturgy is accompanied by singing, that's why music and singing are important means for achieving the mystical state of unity between a man and God in the works of B.-I. Antonych. Besides the musical terms "harmony", "chord", "enharmony", "dissonance", "melody", the poetry of B.-I. Antonychis also abounded with such images as"strings", "concert",

${ }^{42}$ Антофійчук В. “Молитва, як сонце, вічна...” (Жанр молитви в українській літературі). “Святі чуття, закладені в молитву...”: Антологія української молитви. У 2-х кн. Чернівці: Рута, 1996. Кн. 1. Ст. 4. 
"tuning fork", "harp", "lute", "lyre", “violin", “piano", "bells", which are often symbolized and are carried an important semantic loading.

\section{REFERENCES}

1. Антонич Б. I. Повне зібрання творів / Передмова Миколи Ільницького; Упорядкування і коментарі Данила Ільницького. Львів: Літопис, 2009. 968 с.

2. Антофійчук В. “Молитва, як сонце, вічна...” (Жанр молитви в українській літературі). “Святі чуття, закладені в молитву...”: Антологія украӥнської молитви. У 2-х кн. Чернівці: Рута, 1996.Кн. 1. Ст. 3-10.

3. Бетко I. Біблійні сюжети і мотиви в українській поезії XIX початку XX століття. ZielonaGyra - Kijyw, 1999. 160 с.

4. Бетко I. Осмислення нумінозного досвіду в поезії БогданаІгоря Антонича. Бетко I. Українська релігійно-філософська поезія. Emanu розвитку. Katowice: Wydawnictwo Uniwersytetu Śląskiego, 2003. Ст. 174-209.

5. Бовсунівська Т. Молитва як літературний жанр. Дивослово. 2003. № 7. Ст. 3-8.

6. Болгарський Д. До проблеми розуміння православного богослужебного співу. Наукові записки: Збірник наукових статей Національного педагогічного університету ім. М. Драгоманова. Вип. 40. Київ, 2001. С. 74-77.

7. Калинець I. Знане i незнане про Антонича: Матеріяли до біографії Богдана Ігоря Антонича. 2-ге вид., випр. і доп. Львів: Друкарські куншти, 2011. 276 с.

8. Лєпахін В. Ікона та іконічність. Львів: Свічадо, 2001. 288 с.

9. Мень А. В. Таинство, Слово и Образ. Православное богослужение. Москва, 2001. 285 с.

10. Олійник О. Надгробок на могилі щастя. Весни розспіваноӥ князь. Слово про Антонича: Статті, есе, спогади, листи, поезії. Львів: Каменяр, 1989. Ст. 362-369.

11. Прийдіте поклонімся: Молитовник. 5-те вид.випр. Львів: Свічадо, 2007. 988 с. 
12. Ронкі Е. Закоханий і здивований Бог / Пер. з італ. К. Зінченко. Львів: Свічадо, 2015. 80 с.

13. Соловій М., о. Божественна Літургія: Історія - розвиток пояснення. Львів: Свічадо, 1999. 440 с.

14. Сурожский А., митр. Школа молитвы. Клин: Христианская жизнь. 496 с.

15. Токмань Г. Збірка Б.-І. Антонича “Велика гармонія” у діалозі з екзистенціальним богослов’ям. Слово $і$ час. 2002. № 12. Ст. 41-53.

16. Шептицький А., митр. Про церковнийспів (Декрет Собору, читаний дня 25 квітня 1941 р. ст. ст.). Письма-послання Митрополита Андрея Шептицького, ЧСВВ, з часів німеџької окупащії. Йорктон, Саск. (Канада), 1969. Ч. 2. Ст. 56-63.

17. Шмеман А. Символы и символизм византийской литургии: Литургические символы и их богословское истолкование. Синопсис. 2001. № 4/5. Ст. 74-80.

18. Щирі розповіді Прочанина своєму духовному отцеві / Пер. 3 рос. Д. Кічі. Львів: Свічадо, 2005. 232 с.

19. Якубчак Н. Поетика ліричного циклу Б.-І. Антонича. Наукові записки. Том 48. Філологічні науки. Київ: Видавничий дім “КиєвоМогилянська академія”, 2005. Ст. 24-31.

20. Papla E. Muzyczna Liturgia Bohdana Ihora Antonycza (na podstawie cyklu "Wielka Harmonia") Ukraina. Między językiem a kultura. Studia Ruthenica Crakoviensia: 1. / Pod. red. B. ZienkiewiczTomanek, A. Falowskiego. Kraków: Universitas, 2003. S. 371-378.

\section{Information about the author: Dmytriv I. I., Candidate of Philology,} Associate Professor at the Department of Ukrainian Literature and Theory of Literature,

Drohobych State Pedagogical University named after Ivan Franko 24, Taras Shevchenko str., Drohobych, Lviv region, 82100, Ukraine 


\section{THE MEANING OF THE KNIGHT RANK OF IVAN GONTA IN "HAYDAMAKS" BY TARAS SHEVCHENKO: HERMENEUTICAL-COMPARATIVE ASPECT}

\section{Ivanyshyn P. V.}

\section{INTRODUCTION}

Like all the great works of genius authors, the poem "Haydamaks" by Taras Shevchenko constantly attracts the attention of both the specialists and the average reader. Its large-scale, vivid, impressive images left no one from generations of Ukrainians indifferent. Another specificity of the reception of this unique work is variegated, up to the diametrical opposites, interpretative valuations. In general, these valuations can be taken down to three main types (of course, with numerous modifications and subtypes): 1) mostly negative, in which the poem is examined as weakly aesthetically and ideologically, as the work of "not the best", "non-European" (M. Drahomanov, P. Kulish, the young I. Franko, M. Rudnytsky, and others); 2) mostly apologetic, as an artistic value work (O. Ogonovskiy, S. Smal-Stotskiy, L. Biletskiy, D. Dontsov, E. Malanyuk, I. Bryck, Yu. Boyko, V. Smilyanska, G. Klochek, N. Zborovska, Val. Shevchuk, M. Naenko, I. Dzyuba, etc.) and 3) dualistic as a work obviously or hidden ambivalent and contradictory in the ideological and aesthetic plans (partly V. Paharenko, fully Ye. Nahlik, Yu. Barabash and others). For each of these positions there are its logic, methodology, ideology, arguments. However, they are not always checked by the intentions of the work itself, and sometimes simply imposed to the recipient as if it were Shevchenko's auto- valuations.

A typical example of the most controversial interpretation can be the image of one of the protagonists - the leader of the Haydamak's uprising Ivan Gonta. Especially, the culminating episode of the work is the scene of the murder of sons in the part "Gonta in Uman". This impressive rank rarely received deeper interpretation (as in L. Biletskiy or Val. Shevchuk), more often it was only fixed as "the most tragic" scene or "terrible act" 
without a deeper analysis (for example, in I. Bryck or I. Dzyuba) or tendentiously over-interpreted (in the terminology of U. Eko), made it the main proof of the "immorality" and "antiheroicity" of the poem in general (G. Grabovych) and "criminality", "demonicity", "ghoulsness" of the centurion (and, in the same way, all the haydamaks) specifically (L. Plyushch, O. Zabuzhko, G. Grabovych). Even some more thoughtful researchers were inclined to consider Gonta as a victim of the "demons" of "confessional intolerance" and "swarm's solidarity", and his rank - as an act of "moral fall"1.

The problem of full-fledged interpretation of the Gonta's action, which is one of the main keys to the interpretation of the poem in general, needs much more space and time (for example, an appeal to the interpretation of the Koliyivshchyna as a complex historical phenomenon, to ethnopsychological conception of "two Ruthenian nationalities" by M.Kostomarov, to a religious basis of the liberation wars, to the problem of the methodological (not) adequacy of the various interpretations of the work, etc.). Here we confine ourselves to the semantic, hermeneutic outlining of only one comparative aspect which has not yet become the subject of in-depth examination and which, in our opinion, spills some light on the essence of this drastic scene for many researchers, on the temper of the Haydamak leader, and on the deeper meanings of the whole poem.

\section{Gonta as a personification of knightly (extraordinary) type of presence in T. Shevchenko}

Since we are going to talk about parallels with the ancient authorshistorians, then it is also appropriate to point out some (obviously partial) intermediality of the carried out comparative interpretation. In the professional literature the thought, that the antique historiography (Homer, Thucydides, Caesar, Sallust, Titus Livius, Plutarch, Polybius, Tacitus, etc.) was a genre of not so much science as literature, more concretely as artistic prose, became normative. From here - the richness of historical texts with vivid and lively artistic descriptions, the dramatization of the narration, the

\footnotetext{
${ }^{1}$ Барабаш Ю. “Коли забуду тебе, Срусалиме...”. Гоголь і Шевченко. Порівняльнотипологічні студії. Харків. Акта. 2001. С. 169.
} 
containing of invented speeches and letters, the domination of artistic truth over the truth of the fact, etc. ${ }^{2}$ There is some reason to consider these genre synthetic works as close to documentary literature, that is to "artistic and journalistic, scientific and artistic works.., based on the full or partial use of documentary sources"3. Thus, in our case, it is a question of comparing T. Shevchenko's poem as a purely artistic work with the typical works of ancient historians (as syncretic semiotic systems). (Instead, the classical example of a thorough intermedial interpretation of the creative work of T. Shevchenko is the recent works of Gregory Klochek or the monograph of Lesya Generalyuk ${ }^{4}$ ).

The purpose of such a fragmentary hermeneutic-comparative reading is to find out the typical semantic aspects of Ivan Gonta's action in the poem "Haydamaks" through comparison with typologically close inocultural experience, as well as generalization of previous developments ${ }^{5}$.

First of all, if we approach the literary figure of Gonta with impartiality and taking into account that we deal with one of the through archetypal images in the poetry of T. Shevchenko ("To Gogol", "Cold Ravine", "The Great Cellar"), then it is obvious that this character has an in-depth meaning for the poet's creative work. And it is not just that Shevchenko, in the spirit of romantic, "Cossack" (according to Ivan Franko) nationalism, in his creative work models a new type of Ukrainian national man, as a person of a specific free man, a Cossack man. It is also important to realize the other. Within this free Cossack life, he distinguishes ordinary and conducting types. The orphan Yarema in "Haydamaks" is a vivid embodiment of a reborn from a hireling, a Jewish

2 Античная литература: Учеб. для студентов пед. ин-тов. А.Ф. Лосев, Г.А. Сонкина, А.А. Тахо-Годи и др. Под ред. А.А.Тахо-Годи. 4-е изд., дораб. М. Просвещение. 1986. 464 с.

3 Літературознавча енциклопедія: У двох томах. Т. 1. Авт.-уклад. Ю.І.Ковалів. К. ВЦ “Академія”. 2007. С. 294.

${ }^{4}$ Генералюк Л. Універсалізм Шевченка: взаємодія літератури і мистецтва. Київ. Наукова думка. 2008. 544 с.

${ }^{5}$ Іванишин П. Вульгарний “неоміфологізм”: від інтерпретації до фальсифікації Т.Шевченка. Дрогобич. ВФ “Відродження”. 2001. 174 с.; Іванишин П.В. Національний спосіб розуміння в поезії Т. Шевченка, Є. Маланюка, Л. Костенко: монографія. К. Академвидав. 2008. 392 с. 
person of a Cossack person, (the evidence of which is the Haydamak's nickname and his symbolic adoption by Zaliznyak), but ordinary, average type. And this is quite natural, because the essential (existential) Cossack is the one who lives as a Cossack, leading the Cossack way of being. While Gonta is an embodiment of a different type of Cossack presence, a person is definitely extraordinary. And the evidence of this is his not so real life (although there is a lot of exceptional and heroic in it, if at least to recall the knightly, stoic behavior of this leader during inhumane torture), just like the artistic living, which is depicted in the poem.

It seems that for the poet in his sad time (mid-nineteenth century) of total dominance of the type of imperial, colonized, dissolved in the Russian world person - "slaves with a cockade on the forehead", "lackeys in golden decoration" ("In Judah, in the days of them ...") - an important artistic task was to depict a real elite of the people, prototypes for which he finds in the heroic Cossack past (Ivan Pidkova) or creates in his imagination (Gamalia) in folklore and romantic tradition. That is looking for in the blessed and often deliberately idealized time - "as we were Cossacks" ("To the Poles"). It is about the image of the leader-man, the "knight", the upper level of the social hierarchical ladder, the spiritual nobleman, subsequently so thoroughly comprehended in the philosophy of Dmytro Dontsov ${ }^{6}$ and the literary work of other visnykivtsi.

By the way, the deep allegorical image of the organic leader (as the "shepherd"), which goes beyond the strictly religious sense, is observed in the New Testament. Christ, in one of his parables, takes out an antinomic pair, opposing the "good shepherd" to the pseudo-elite (heteronomous) "hireling": "I am a good shepherd. A good shepherd will put his life behind the sheep. A hireling is not a shepherd to whom the sheep belong - sees the wolf coming in and leaves the sheep and runs away. And the wolf grabs them and shakes. Because he is a hireling and does not care about the sheep" (Jn 10: 11-15) ${ }^{7}$. It is typical that such a parabolic interpretation of the spiritual type of the leader (and, accordingly, the false leader) is echoed with the existential identification of a person just as a shepherd or shepherd

\footnotetext{
6 Донцов Д. Дух нашої давнини. Дрогобич. ВФ “Відродження”. 1991. 341 с.
}

${ }^{7}$ Святе Письмо Старого і Нового Завіту. Рим. б.в. 1988. 1407 с. 
of being in the hermeneutics of Martin Heidegger. The German philosopher perceives the shepherd nature through the mode (existential) of care: "People are still what they are worried about" 8 . The national leader, from here, is when he really cares not about private, family or clan, but nationwide things and affairs.

In the poetry of $\mathrm{T}$. Shevchenko in such christological-nationalistic spirit (from here the criteria and frequent criticism of false leaders by the poet, for example, in the "Epistle") it is depicted many heroes-leaders. However, as it seems suitable to remark, the image of Ivan Honta, which was taken out in "Haydamaks", still appears as the key ideal image of the Ukrainian elite ("knightly", according to T. Shevchenko) here-being (the leader of the people). It is with the help of this throughout romantic character the author interprets to the recipient who must be a true national leader.

His final development the image of Gonta as an image of the leader (shepherd) of the people gets in the culminating part of the poem "Gonta in Uman". In contrast to the historical Gonta, who had four daughters and one son and who did not hurt them in any way ${ }^{9}$, Shevchenko's character in the spirit of artistic truth (according to the realities of the figurative world, to the content and meaning of the poem) makes an impressive action on the strength of the spirit - he executed two of his small Catholic sons during the battle in Uman, directly provoked to do this by the words of their Jesuit instructor: "Look, Gonta, look! These youngsters are your sons! They're Catholics: since you kill all, Can you leave them alone? Why are you waiting? Kill them now, Before your sons are grown, For if you don't, when they grow up They'll find you and they'll kill..."10.

Historical Gonta personally saved many familiar umantsi from Haydamak's revenge, demonstrating a typical deep humanity for the

\footnotetext{
${ }^{8}$ Хайдеггер М. Бытие и время. Пер. с нем. В.В.Бибихина. Харьков. “Фолио”. 2003. C. 362 .

9 Зінчук С. Славні хлопці гайдамаки. Запорожці: До історії козацьк. культури. Упоряди. тексту, передм. І. Кравченка. Упорядк. іл. матеріалу Ю. Іванченка. К. Мистецтво. 1993. С. 255.

${ }^{10}$ Шевченко Т.Г. Повне зібрання творів: У 12 т. Редкол. М.Г. Жулинський (голова) та ін. К. Наук. думка. 2001. Т. 1. Поезія 1837-1847. Перед. слово І.М. Дзюби, М.Г. Жулинського. С. 181.
} 
temper of an ethnic Ukrainian. His literary embodiment also shows humanity, but of a different type, and in another way. For this significant dramatic action, the murder of children, is suitable not ordinary, but only a great man, in another classical terminology, the hero (that is, in the ideas of the ancients - the demigod, the holy, divine, hero, the ideal person, etc.). And that exactly a person, and not a demonized, immoral cruel person, proves yet another psychologically tense megaimage (scene) of the part the secret funeral of the killed sons by Gonta ("... so that the Cossack small body / Dogs did not eat”), where a huge parental love pours out bloody tears, self-punishment, but not repentance: "My children! Open up your eyes, Look at Ukraine, my boys: For her, my sons, you gave your lives And I, too, am destroyed"

Only a great man, a true leader of the people, has the wisdom to subordinate the smaller, privately-owned love (parental) to a larger, allencompassing, overpersonal (sacrificial love for the Motherland). Here, love for children is like a continuation of the Fichte's love of man to "himself", which, in order the people to live, should not predominate over "love for the Motherland"12. Only a great man, a true Christian, a "good shepherd" has the nobility to realize that the "great sin" (according to Weber's "persuasion ethics") of murdering children is still less a sin than a shepherd sin (according to the ethics of responsibility) of national treason the murder of the faith of his spiritual children-charges (especially during the time of the nation-wide war for freedom, as Shevchenko rethinks in his poem the historical and, in some aspects, destructive rebellion of the coliyi in 1768). Because in this case it is, in fact, about the murder of a coexistential mode of trust between the leader and his subordinates, his new family, and the "children" is a constant appeal of atamans to simple haydamaks. Only a great man, a leader of the people, a true Cossackknight, has the courage to regulate his actions with a position of good for the community and, if necessary, can donate the family happiness for the

11 Шевченко Т.Г. Повне зібрання творів: У 12 т. Редкол. М.Г. Жулинський (голова) та ін. К. Наук. думка. 2001. Т. 1. Поезія 1837-1847. Перед. слово І.М. Дзюби, М.Г. Жулинського. С. 185-186.

12 Фіхте Й.Г. Із праці “Промови до німецької нації”. Мислителі німецького Романтизму. Упор. Леонід Рудницький та Олег Фешовець. Івано-Франківськ. Лілея-НВ. 2003. C. 235; C. 133. 
sake of everyone happiness. The presence of a leader is structured not only by parental care (which is normal for an ordinary national person of a family type in normal, peaceful time of the world "cherry garden near the house"), but nationwide care - national imperative embodied in the form of an "oath" (dominant in the boundary, according to K. Yaspers, dramatized war time of the world of "sable" or "sacred knife"):

The Cossacks stood

Assembled in the square.

"My sons are Catholics.... I vowed

No Catholic to spare.

Esteemed assembly!... That there should

Be no doubt anywhere,

No talk that I don't keep my word,

Or that I spare my own..."

"...Such woe, my sons, today is mine

As cannot be conceived!

My children, kiss me, for not I

Am killing you today -

It is my oath! ", 13 .

\section{Gonta's heroism in the comparative aspect}

Comparisons, to which the Shevchenko's scholars properly paid attention (although often episodically) and which are concerning to the action of the biblical patriarch Abraham, who was ready to sacrifice his innocent son Isaac to God (Genesis 22: 1-13), the sacrifice of the daughter Iphigenia to Artemis by the Achaean king Agamemnon in the "Iliad" by Homer, or, again, kid murder, but deserved, of the renegade son Andrew by Taras Bulba depicted in M. Gogol's work, can be a good context for a clearer understanding of Gonta's action and, from here, the greatness of his leading nature (Gonta emerges as a potential political leader of the restored Cossack state). These comparative parallels

13 Шевченко Т.Г. Повне зібрання творів: У 12 т. Редкол. М.Г. Жулинський (голова) та ін. К. Наук. думка. 2001. Т. 1. Поезія 1837-1847. Перед. слово І.М. Дзюби, М.Г. Жулинського. С. 182. 
explain the action of the Haydamak's ataman in many aspects, however, besides this, no less important are such historical examples (the primary sources of many literary stories in different European peoples), on one of which I. Franko hints (obviously developing the opinion of P. Kulish), though not perceiving the action of Haydamak's ataman, "Shevchenko makes Ukrainian Brutus from Gonta" ${ }^{14}$. So, let's appeal to the ancient historians for explanation, remembering that T. Shevchenko holds an active creative dialogue with different traditions (Christian, folklore, historical, literary, etc.), and also (as it was retraced in the writings of O. Biletskiy or Yu. Boyko) with ancient tradition (both in their paintings and in literary works).

Killing yourself or your relatives in the name of an over-personal goal, often for the sake of preserving the existence of the native people (the existence of the nation, as we would have said now), is quite common in the ancient history of various cultures, although perhaps the history of the Romans as semi-artistic story about the formation of a powerful Roman state offers us the most documented evidences. What is worthy the murder of his sister by Horace at least described by Titus Livius. This hero, triumphantly returning from a difficult battle and carrying an armor got in the fight of the twins he killed - Albanians Kurnatsiyi, noticed how his sister cries at the gates of Rome for one of them - her groom. Indignant by the fact that the girl is not crying for two dead brothers (killed by Kurnatsiyi, the fight was - three to three), the brother pierces her with a sword, saying, among other things, the following: "... you forgot about the brothers - about the dead and the living one - forgot about the motherland. Let every roman woman, who will mourn for the enemy, die like this!". Horace was judged by the people, but at the request of his father and under the impression of the previous feat the young man was pardoned ${ }^{15}$.

The action of Horace, though carried out for the sake of the people (the Romans should not mourn the enemy of their motherland), is rather,

${ }^{14}$ Франко І. Нарис історії українсько-руської літератури до 1890 р. Франко І. Зібр. творів: У 50 т. К. Наукова думка. 1984. Т. 41. С. 277-278.

15 Ливий Тит. История Рима от основания Города: В 3 т. Т. 1. Кн. І-Х. Тит Ливий. Сост. коммент. В.М. Смирин, Г.П. Чистяков, Ф.А. Михайловский. М. «Ладомир». 2002. C. 36-38. 
unreasonable, impulsive, instead, the murder of his sons by the first Roman consul, Lucius Junius Brutus (who was called "the father of freedom") was a weighted decision and more like a strict rank of Gonta. Soon after the Romans, draw out the family of the degenerated (and therefore tyrannical) kings Tarquiniyi under the leadership of Brutus, the ancient authors say, the freedom of the republic almost ruined the plot of some young and noble Romans, who entered into relations with the king Tarquiniy The Proud. The plot was revealed, and two sons of Brutus - Titus and Tiberius (the first typical parallel with the artistic model of kid murder in "Haydamaks") were between the rebels.

The following description of the events in the sources is slightly different. According to Titus Livius, the consul Brutus along with his friend by the consulate Publius Valery convicts the rebels (the betrayers not only of "liberated motherland" and "father-liberator", but "all that was in Rome of God and man") to a public execution (according to a custom, the lictors flog convicted near the post and decapitated with an ax). During the execution Brutus sits on his power seat, his face and his vision "show a

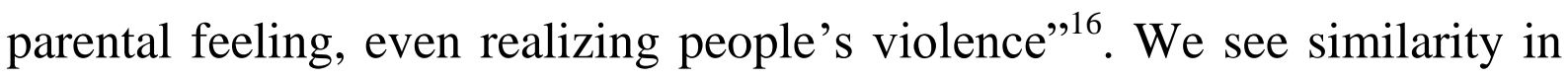
the Gonta's words during the execution of his sons, speaking in Shevchenko's words, the "breaking" of the "living heart" ("Cold Ravine"), we hear a great, although restrained in front of face of the congeners, pain of "parental feelings" (especially bright in that - "... Kiss me, children, / Because I do not kill...”), which fully manifests itself during a lonely funeral.

Plutarch's description is even stricter. Brutus immediately after questioning the sons on the forum orders them to execute. At the same time, he does not take his eyes, without sympathy, watches at the punishment of his children with a strict look. Sending the rest of the rebels to the court of his comrade on the post, Brutus goes away. Ancient Greek historian points out that the consul's action "steps out beyond the human nature" (F. Nietzsche maybe would call it as the action of a superman), but warns the reader of the conviction: "More fairly ... that our reflection about

16 Ливий Тит. История Рима от основания Города: В 3 т. Т 1. Кн. І-Х. Тит Ливий. Сост. коммент. В.М.Смирин, Г.П.Чистяков, Ф.А.Михайловский. М. «Ладомир». 2002. C. $77-80$. 
this man goes after his glory, and our own weakness should not be the cause of distrust of his valor. In any case, the Romans believe that not so much work cost Romulus to found a city, but Brutus - to found and strengthen a democratic way of government" ${ }^{\prime 17}$. T. Shevchenko models similar "high valor" in the character of Gonta and, creating the ideal model of a statesman - the leader of the people, which had a fundamental nationcreative in the crushing conditions of Russian occupation and colonization of Ukraine.

However, at least one essential detail of the rank of Brutus is still different from that one of Gonta: the sons of the consul were still guilty for the betrayal of the Romans, and the fault of the young Ukrainians is more formal - they are "Catholics" (converted by the mother, and therefore, they belong, according to the tradition of that time, to another, Polish, national identity), and only because of this fall under the sacred Haydamak's oath. True, the sons of Gonta are only potential, possible (and then in the future), but not efficient (actual) enemies of the people or people's affair, and in this case, the rank of the Haydamak's leader in the poem predominates over the grandeur of spirit, dramatism, tensity of will power, a similar action of the Roman leader. In the outlined moment, the courageous Gonta's action manifests through two more comparative parallels.

The first one concerns to Brutus's congener in the consulate Publius Valery (in Rome nicknamed Publikola - "the friend of the people"), who, according to Plutarch's evidence, destroyed one of his magnificent, luxurious houses in one night, precisely in order to "have no talk", speaking in Shevchenko's words, so that the Romans could not even see the symbol of the tyranny of exiled Tarquinia in such a building - the ruined royal palace ${ }^{18}$. However, the property is not children. Here the similarity is less profound, narrowed typological. Titus Livius gives us another parallel on the example of the Roman consul, Titus Manliy, who swore to give life to the Roman people (compare with the "oath" of Gonta) and ordered to punish his son on the throat, for the fact that during a very exhausting and dangerous war with

${ }^{17}$ Плутарх. Сравнительные жизнеописания в 3-х томах, т. III. СПб. Кристалл. 2001. C. 184-188.

${ }^{18}$ Плутарх. Сравнительные жизнеописания в 3-х томах, т. III. СПб. Кристалл. 2001. C. 191. 
Latins, broke the order and entered the battle with the enemy. And although the son won the enemy rider in the fight, the consul, not forgetting that he was a father (“... you are dear to me, as my natural son ..."), nevertheless he punishes him for a bad example ("...blew up obedience in the army, on which the Roman state still remained..."), which could cause to anarchy, otamanshchyna (such sadly famous in later Roman and Ukrainian histories), and hence to the death of the Roman people and the state. Choosing between the death of his son, which should "strengthen the sacred power of the consuls in the war" and pardon, which "will forever blow up" the faith in this power, Manliy, like Gonta, chooses the first ${ }^{19}$.

Parallels with the great leaders (first of all politicians) of the Roman people, the classical incarnations of the Roman man (presence) - Horace, Brutus, Valerius and Manliy - help us to comprehend the greatness of the artistic character of the Ukrainian leader - Ivan Gonta. In all cases, we probably have to deal (here it is worthy to generalize the opinion of the Russian historian G. Knabe) "not with barbarian cruelty, and all with the same faithfulness to freedom, before which everything retreats" 20 . True, it is very difficult to comprehend the people who are blocked by certain universalist - imperial or cosmopolitan - stereotypes and a way of thinking, with which, incidentally, T. Shevchenko's hero wittily argues in the introduction to "Haydamaks". "It is said: If we are slaves ourselves, then for us there can be no heroes. We do not recognize the hero ..."21wrote a philosopher Thomas Carlyle from a similar occasion.

T. Shevchenko, as a special aristocrat of the spirit, comprehended the heroic phenomenon very deeply. It is no by chance that in his poetry he introduces an original (because it is not about religious or mythological "adoration",22, but, obviously, the confirming of the essential artistic and existential mode of respect as a kind of care) cult of Gonta as a hero. That

19 Ливий Тит. История Рима от основания Города: В 3 т. Т 1. Кн. І-Х. Тит Ливий. Сост. коммент. В.М. Смирин, Г.П. Чистяков, Ф.А. Михайловский. М. «Ладомир». 2002. C. $453-454$.

${ }^{20}$ Кнабе Г.С. Рим Тита Ливия - образ, миф, история. Ливий Тит. История Рима от основания Города: В 3 т. Т. 3. Кн. XXXIV-XLV. Тит Ливий; Сост. коммент. В.М. Смирин, Г.П. Чистяков, Ф.А. Михайловский. М. «Ладомир». 2002. С. 763.

${ }^{21}$ Антология мировой философии. В 4-х т. М. Мысль. 1971. Т. 3. С. 657.

${ }^{22}$ Словник іншомовних слів. Уклад.: С.М. Морозов, Л.М. Шкарапута. К. Наук. думка. 2000. С. 309. 
is an example for imitation as almost inaccessible to an ordinary person, as the embodiment of "Cossack's glory", finally, as a hero (the historycreative "great man") in a philosophical and national sense ${ }^{23}$. Such Shevchenko's interpretation resembles the interpretation of the hero in the ancient Greeks as "an outstanding ancestor - the leader, the legendary founder of the tribes and peoples, the founder of cities" etc. ${ }^{24}$, and in the etymologically Christological sense as the saint ("righteous martyr"), which is being actualized in the poem too. At the same time, the lyrical hero reproaches the "grandchildren" (modern yarema-persons) who are indifferent to the Haydamak's affair, who do not even know where are the graves of Honta and Zaliznyak. That is, they do not know very important existing ones (and not only for the lyrical hero) in the nation-creative sense, do not know their spiritual ancestors, do not know the basics and sources of their national being: "Hard! Hard! Executioner rules, / And they will not be remembered ${ }^{, 25}$.

Naturally, therefore, the image of Gonta, and even more the Cossack character embodied in this form, is taken out as one of the leading ideals of the Ukrainian person (both for the ordinary and for the leading types). He is taken out as one of the models of national here-being in a number of T. Shevchenko's works until the end of his creative work. We see such an author's interpretation in the message "To Gogol" (1844): "No cannon roar now in Ukraine / With voice of Liberty; / Nor will the father slay his son, / His own dear child, with pain, / For honour, glory, brotherhood, / The freedom of Ukraine. / He'll rather rear him up to sell / To Moscow's slaughterhouse..." 26 . And in the mystery "The Great Cellar" (1845) (the image of the first John, all three crows are frightened by him): "One

\footnotetext{
${ }^{23}$ Карлейль Т. Герои, культ героев и героическое в истории. Психология толпы: социальные и политические механизмы воздействия на массы. М. Изд-во Эксмо. Спб. Terra Fantastica. 2003. C. 469-717.

${ }^{24}$ Плутарх. Сравнительные жизнеописания в 3-х томах, т. III. СПб. Кристалл. 2001. C. 620.

${ }^{25}$ Шевченко Т.Г. Повне зібрання творів: У 12 т. Редкол. М.Г. Жулинський (голова) та ін. К. Наук. думка. 2001. Т. 1. Поезія 1837-1847. Перед. слово I.М. Дзюби, М.Г. Жулинського. С. 158.

${ }^{26}$ Шевченко Т.Г. Повне зібрання творів: У 12 т. Редкол. М.Г. Жулинський (голова) та ін. К. Наук. думка. 2001. Т. 1. Поезія 1837-1847. Перед. слово І.М. Дзюби, М.Г. Жулинського. С. 284.
} 
will be like that Gonta, / Torture the executioners (...) / ... when that Gonta will grow, / All our will be lost! / Everything will destroy / And he will not leave the brother! / And will dismiss the truth and will / Throughout Ukraine!" "27. And in the images of Haydamak's and their leaders in the "Seamstress"28 (1848). And in this real man - "one Cossack / of a million swineherds, / Who declared the whole kingdom - / flooded Satrap in the muzzle",29 - from the "Holy fool" (1857). And in many other works, where this Cossack character is expressed obviously ("Blind man" (1845) or "Sometimes, in slavery I will remember ..." (1857)) or hidden, often in the image of the lyrical hero ("Neophytes", "Dream", "Caucasus", "I'm not sick, nothing...", "If you had to ...", "If you were, drunk Bogdan ...", "In Judah, in the days of them...", "Hosea, Chapter IV", "Somehow going at night ...", "Imitation to 11 psalm", etc.).

However, the most clearly Shevchenko expresses his interpretation of Gonta with the lyrical hero's lips in "Cold Ravine" (1845), answering all the past, contemporary, and future Ukrainophobes ("new executioners", "fierce Neros", "tsaryks", "liudomors", "unsatisfied robbers") and their alienated from the life-giving national tradition assistants ("fools", "sheep's natures”, “lazy lazybones”):

Forsooth yours is

Indeed a sheeplike nature!

The fool offers his neck, not knowing

What for it is wanted,

And, what is more, the idle loafer

Scorns and sneers at Gonta!

The Haydamaky were no warriors,

Thieves they were, and robbers,

A blot upon our history!

27 Шевченко Т.Г. Повне зібрання творів: У 12 т. Редкол. М.Г. Жулинський (голова) та ін. К. Наук. думка. 2001. Т. 1. Поезія 1837-1847. Перед. слово І.М. Дзюби, М.Г. Жулинського. С. 322.

${ }^{28}$ Шевченко Т.Г. Повне зібрання творів: У 12 т. Редкол. М.Г. Жулинський (голова) та ін. К. Наук. думка. 2001. Т. 2. Поезія 1847-1861. С. 133-134.

${ }^{29}$ Шевченко Т.Г. Повне зібрання творів: У 12 т. Редкол. М.Г. Жулинський (голова) та ін. К. Наук. думка. 2001. Т. 2. Поезія 1847-1861. С. 258. 
Thou liest, people-starver:

For freedom and the holy truth

A robber does not rise up,

Nor does he set free a people

Who, dark, unlightened,

Are bound into your chains, does not

Slay with his own hand

An evil son, nor break his living

Heart for his native land! ${ }^{30}$.

\section{CONCLUSIONS}

Thus, in the image of Ivan Gonta, T. Shevchenko forever prints the Ukrainian archetypal ideal of the Cossack knight's presence for the entire national culture of the New Age, a high, heroic example of herebeing a great man, the leader of the nation. Therefore, probably, those researchers, who, like D. Dontsov, are not very wrong in conclusions from the poetry of Kobzar that only the leading class, armed with spiritual knights' worth of wisdom, nobility and courage, "a race of strong spirits of giants" (Gonta or Mazepa) is capable to take Ukraine out of colonial hell "from the darkness, from stench, from slavery" 31 . In this, as it seems possible to notice, it is one of the essential, ontological and existential aspects of what Yu.Boyko defines as "the life-creative force of nationalism"32.

We are well aware that the mentioned above comparative parallels and accompanying national-existential (nationalistic) hermeneutic reflections are far from exhausting the problem. However, we hope that they can be developed in other studios in plan of complex, versatile interpretation of the whole poem "Haydamaks" as one of the key works to understand the creative work of Taras Shevchenko.

${ }^{30}$ Шевченко Т.Г. Повне зібрання творів: У 12 т. Редкол. М.Г. Жулинський (голова) та ін. К. Наук. думка. 2001. Т. 1. Поезія 1837-1847. Перед. слово І.М. Дзюби, М.Г. Жулинського. С. 356.

31 Донцов Д. Незримі скрижалі Кобзаря (Містика лицарства запорозького). Торонто. Гомін України. 1961. С. 25; С. 81.

32 Бойко Ю. Творчість Тараса Шевченка на тлі західноєвропейської літератури. Бойко Ю. Вибране. У 3 т. Мюнхен, 1971. Т. 1. С. 295. 


\section{SUMMARY}

In the article in hermeneutic and comparative plans, it is considered the rank of centurion Ivan Gonta in the poem by T. Shevchenko "Haydamaks". The researcher focuses on comparative parallels with antique (first of all ancient Roman) heroes, which allow us to comprehend the authentic, immanent meaning of the most controversial scene in the poem "Haydamaks" - the murder of his own young children by Ivan Gonta. In general, Gonta is an embodiment of another, in comparison with the usual, type of Cossack presence, a person clearly extraordinary. And there is evidence of this, not so real his life (although there are many exceptional and heroic, if at least turn to memories, stoic behavior of this leader during inhuman torture), just like that artistic residence, which is described in the poem. That's why, the author emphasizes that the poet, in the form of the Haydamak's leader, models the Ukrainian heroic ideal of the national leader. That is, in the image of Ivan Gonta T. Shevchenko forever marks for the entire national culture of the New Age the Ukrainian archetypal ideal of the Cossack knight's presence, the high, heroic example of here-being a great man - the leader of the nation. For the context the images of ancient heroes - Horace, Brutus, Valery, Manliy, depicted in the works of Titus Livius and Plutarch, are enlisted. These mentioned comparative parallels and accompanying national-existential (nationalistic) hermeneutic reflections are far from exhausting the problem. However, the researcher hopes that they can be developed in other studios in plan of complex, versatile interpretation of the whole poem "Haydamaks" as one of the key works to understand the creative work of Taras Shevchenko.

\section{REFERENCES}

1. Античная литература: Учеб. для студентов пед. ин-тов. А.Ф. Лосев, Г.А. Сонкина, А.А. Тахо-Годи и др. Под ред. А.А. ТахоГоди. 4-е изд., дораб. М. Просвещение. 1986. 464 с.

2. Антология мировой философии. В 4-х т. М. Мысль. 1971. T. $3.760 \mathrm{c.}$

3. Барабаш Ю. “Коли забуду тебе, Єрусалиме...”. Гоголь $i$ Шевченко. Порівняльно-типологічні студії. Харків. Акта. 2001. 374 с. 
4. Бойко Ю. Творчість Тараса Шевченка на тлі західноєвропейської літератури. Бойко Ю. Вибране. У $3 \mathrm{~m}$. Мюнхен, 1971. T. 1. С. 261-312.

5. Генералюк Л. Універсалізм Шевченка: взаємодія літератури і мистецтва. Київ. Наукова думка. 2008. 544 с.

6. Донцов Д. Дух нашої давнини. Дрогобич. ВФ “Відродження”. $1991.341 \mathrm{c}$.

7. Донцов Д. Незримі скрижалі Кобзаря (Містика лицарства запорозького). Торонто. Гомін України. 1961. 231 с.

8. Зінчук С. Славні хлопці гайдамаки. Запорожиі: До історії

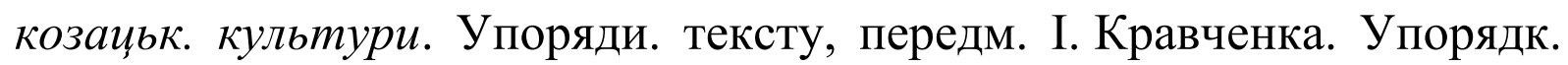
іл. матеріалу Ю.Іванченка. К. Мистецтво. 1993. С. 252-280.

9. Іванишин П. Вульгарний “неоміфологізм": від інтерпретації до фальсифікації Т. Шевченка. Дрогобич. ВФ “Відродження”. 2001. $174 \mathrm{c}$.

10. Іванишин П.В. Національний спосіб розуміння в поезії Т. Шевченка, С. Маланюка, Л. Костенко: монографія. К. Академвидав. 2008. 392 с.

11. Карлейль Т. Герои, культ героев и героическое в истории. Психология толпы: сочииальные и политические механизмы воздействия на массы. М. Изд-во Эксмо. Спб. Terra Fantastica. 2003. C. 469-717.

12. Кнабе Г.С. Рим Тита Ливия - образ, миф, история. Ливий Тит. История Рима от основания Города: В 3 m. T. 3. Кн. ХХХIV-XLV. Тит Ливий; Сост. коммент. В.М. Смирин, Г.П. Чистяков, Ф.А. Михайловский. М. “Ладомир”. 2002. С. 647-709.

13. Ливий Тит. История Рима от основания Города: В 3 т. Т 1. Кн. І-Х. Тит Ливий. Сост. коммент. В.М. Смирин, Г.П. Чистяков, Ф.А. Михайловский. М. “Ладомир”. 2002. 702 с.

14. Літературознавча енциклопедія: $\mathrm{У}$ двох томах. Т. 1. Авт.-уклад. Ю.І. Ковалів. К. ВЦ “Академія”. 2007. 608 с.

15. Плутарх. Сравнительные жизнеописания в 3-х томах, т. III. СПб. Кристалл. 2001. 772 с.

16. Святе Письмо Старого і Нового Завіту. Рим. б.в. 1988. 1407 с. 
17. Словник іншомовних слів. Уклад.: С.М. Морозов, Л.М. Шкарапута. К. Наук. думка. 2000. С. 309.

18. Фіхте Й.Г. Із праці “Промови до німецької нації”. Мислителі німеиького Романтизму. Упор. Леонід Рудницький та Олег Фешовець. Івано-Франківськ. Лілея-НВ. 2003. С. 110-134.

19. Франко I. Нарис історії українсько-руської літератури до 1890 р. Франко І. Зібр. творів: У 50 m. К. Наукова думка. 1984. Т. 41. C. $194-471$.

20. Хайдеггер М. Бытие и время. Пер. с нем. В.В. Бибихина. Харьков. “Фолио”. 2003. 503 с.

21.Шевченко Т.Г. Повне зібрання творів: У 12 т. Редкол. М.Г. Жулинський (голова) та ін. К. Наук. думка. 2001. Т. 1. Поезія 1837-1847. Перед. слово І.М. Дзюби, М.Г. Жулинського. 784 с.

22. Шевченко Т.Г. Повне зібрання творів: У 12 т. Редкол. М.Г. Жулинський (голова) та ін. К. Наук. думка. 2001. Т. 2. Поезія 1847-1861. 784 c.

\section{Information about the author:} Ivanyshyn P. V.,

Doctor of Philology, Professor, Head of the Department of Ukrainian Literature and Theory of Literature, Drohobych State Pedagogical University named after Ivan Franko 24, Shevchenko str., Drohobych, 82100, Ukraine 


\section{"PHILOSOPHY OF ACTION" IN THE PROJECTION OF "AUTHORITATIVE STYLE" OF ULAS SAMCHUK}

Maftyn N. V.

\section{INTRODUCTION}

Overcoming the "passionar breakdown" in Western Ukrainian prose at the end of the 20-30's of the twentieth century was largely stimulated by the force field of "Art militans" created by "visnykivtsi". Volitional nationalism has become a powerful factor in the formation of the dominant of ethnogenesis at a new stage, and although in the speeches and journalism of his inspirer has a lot of too categorical accents, yet "the philosophy of action" created crystallized in the writings of D. Dontsov and his colleagues (in particular Yu. Lypa and Ye. Malaniuk) marked the horizons of new hopes of the national future and formed the basis for the intentionality of art.

The presence of the "authoritative points of view" in the social, political and literary life of Galicia during the second half of 20's-30's as clearly prevailing ideological and aesthetic dominants and clear ideological assessments contributed to the realization of the idea of "grand style" in specific manifestations of authors' styles that were based on a clear writer's worldview position. The category of "authoritative style", introduced in the literary tradition for the first time by M. Bakhtin ${ }^{1}$ as "the key to the epoch" and applied to the analysis of the poetics of Dostoevsky, precisely implies the attraction to the direct expression of the author's position which is possible provided that there are "authoritative points of view" and "crystallized ideological assessments" in the force field of the epoch. The category offered is in a certain way resonance with the category of "participants' poetics" defined by V. Derzhavyn in a number of his works devoted to poetics and the style of Ukrainian diaspora literature. It is crystallization of the "authoritative style", transforming the problem

\footnotetext{
${ }^{1}$ Бахтин М. Проблемы поэтики Достоевского. М. , 1963, 363 с.
} 
of interaction between the subjective and objective principles in the process of creating stylistic forms, gave rise to new types of relations between the life material and the artistic thought of the writer, new forms of style activity.

The "authoritative style" of Western Ukrainian and emigration prose was created by the bright facets of authors' styles of artists whose individually artistic thinking was marked by the organicity of artistic vision and expression as an original artistic system, while the "expressive system" of these artists' prose is determined by the dominant moments of the writer's orientation and the target directions of the artist as a person, in the first place - by passionary impulses.

The problem of depicting a person in a literary work is one of the leading in literary criticism. After all, even the form of fiction work in many aspects is determined by the way the author feels his character who is the organizing center of the statement. And this "feeling" has, among the many others, at least at the level of pathetic tonality, the most general prospects: heroic-tragedy, lyrical-meditative, humorous, realisticpsychological. Analyzing the literature of "defeatist" direction, D. Dontsov emphasized the inequality of these perspectives as one of the main defects of literature of such a kind ${ }^{2}$.

The new level of intellectual-sensory consciousness, based on the philosophy of action and therefore took it as the starting point of the modelling of the national character in the artwork, was proved by Ulas Samchuk's prose. The images-anthoropologemes of his epic canvases and novella forms of the deep fullness of the character of the representatives of the "soil race" manifested Franko's “... a man is a prologue, not an epilogue." Created by Samchuk image-character of Volyn peasant, a "person" does not object a "hero" - character's world of "Volyn", "Mariia", "Kulak" is presented by complete figures full of vital energy of action that is aimed at the conquest of the environment and life.

Here the core of Samchuk's individual style is rooted, a style whose strength and energy is contained in the active focus on comprehension of the world and the aesthetic organization of existential "chaos." The writer,

\footnotetext{
${ }^{2}$ Донцов Д. Дві літератури нашої доби. Львів, 1991.
} 
with his mighty narrative, rooted in the deep national tradition, sought to regenerate Ukrainian space as the space of the grain-producing nation - the "soil race" - from the hell of darkness and darkness that absorbed Ukraine in the Soviet empire, so it is not surprising that the powerful energy of Samchuk's word carries in itself the nation-affirming congratulatory code. Artistic images of his novels are endowed with a special capacity and vitality - they have become a concentrated embodiment of life itself.

U. Samchuk's prose also witnessed a departure from the closed style system characteristic of classical romantics of the nineteenth century closed in relation to the expression of the author's consciousness. Samchuk appears as the creator of a narrative form that actively develops the principles of subjective multiplicity of narrative, enriches this system with the diversity of character plans - "characterizes the reality by its own "voices" inscribed, however, in the plan of the author" (H. Bielaia). Materializing in style, the direction of artistic thinking of U. Samchuk expressly testifies the "poetry of the participant" - an active conqueror of life marked by a maximum of sense of life under the sign of purpose. After all, "the style is the directly felt presence and expression of this presence in every component of the work and in the finished work as a whole." (M. Hirshman)

The fact that since 1929 the writer actively collaborated with "Literary-Scientific Bulletin" on the pages of which, the novel "Kulak" (1931) was published, evidences the direct influence on the formation of Samchuk's style of the "field of power" of the ideas of D. Dontsov.

\section{Characters of the novels by U. Samchuk "Volyn" and "Kulak" and "Mariia" are representatives of an active life position concordant with Dontsov's ideology of "action"}

The most prominent achievement of Ulas Samchuk by the researchers of his creative work considered the novel-trilogy "Volyn" rightly emphasizing that this epic canvas the artist created the anthem of Voln, peasant labor, love for the land, and the family foundations of folk life. It was by "Volyn saga" that U. Samchuk declared himself as a master of disruptive epic thinking, who has the talent to see both the fate of a 
separate human person and of the whole people; the philosopher, who is looking for answers to the questions of the historical purpose of this people, the speaker of the most important spiritual values, which determine the profound level of mentality of the nation and the foundations of humanism. In the view of the artist - the formation of national consciousness of Volyn peasant in the vortex of violent events of the World War I, revolution, declaration of UPR (Ukrainian People's Republic), Polish occupation. Therefore, the characters of his "Volyn" are representatives of an active life position, concordant with Dontsov's ideology of "action", an act.

Significantly, in the report "Ideological motives of my creativity", delivered at the University of Ottawa on February 28, 1971, the author said that passionarity of his own creativity, its direction towards national idea: "I thought that the fight is the real phenomenon of life, but not as selfpurpose, but only as a means to the goal. Therefore, it must be guided not only by the blind instinct as anarchy of the act, but also by the conscious will, as an organized function.

Approximately in the range of such an ideological teaching, I built my creative conception, their caharacter type and their philosophy. I wanted to see the Ukrainian village, its life not only as an object of external image, but also as a subject of a certain symbolic doom, from which the new Ukrainian spirituality with a new historic task must come to an end"3.

In the center of Samchuk Volyn "saga" is the national Ukrainian space, the model of which is the Dovbenko's farmstead and the history of the Ukrainian family as the main link of the Ukrainian ethnos. Therefore, the image creation on the pages of "Volyn" tends to monumentalism, because in the sacrum of this kin, in the field of its sacred living space, everything must be marked by a feature of authenticity, reliability, nonpassing. Already the beginning scene of the novel contains an anthropological projection of the spatial model of the world in this trilogy: the living space of Volodka and the whole family (as the Ukrainian patriarchal family) is closely connected to the figure of the father. Matvii

${ }^{3}$ Самчук У. Ідейні мотиви моєї творчості. Роздуми про літературу: збірник літературно-критичних статей / упоряд., примітки, післямова М. Я. Гона. Рівне. 2005. Ст. 62. 
Dovbenko is an image of a Ukrainian peasant who is firmly entangled with troubles in the earth, the soil, yet his spiritual life is directed to heaven. Matvii reminds both Biblical patriarch and descendant of Kyiv Kozhumiaka, victorious victor of a serpent; therefore, in the system of image creation of this character hyperbolization is involved: "The height of Matvii is great. His figure is powerful, firmly built "which today no longer exist." Work burns in his hands. The earth bends when he goes. Strikes with his fist and you do not need to have the beaters. Man as the oak." Samchuk's character does not tolerate falseness, therefore, he himself is a real, reliable, like earth, and inspired by the work on this earth.

Diligent, rigorous and wise, honest, endowed with a sharp mind - this is how Matvii Dovbenko appears on the pages of "Volyn". His language, meaningful, deprived of vain words, reveals the depth of character, the perseverance of his spiritual foundations. He is not conceivable without his native Lebedshchyna, Tyliavka, Volyn - his small homeland which appears as a "promised land" and can give Ukrainian person the power to confirm him/her-self in the world" (R. Movchan). Therefore, the opinion of the researchers about the image of the native land as a key metaphor that permeates all levels of the text is correct: "From this key metaphor - the retreat to wider, symbolic deployments and to its specificity in the image of Volyn" of all the components of the artistic world that Samchuk managed to create a surprisingly integral image of a Ukrainian peasant who combined in himself a "man" and a "hero". It is noteworthy that the whole image structure of Volyn is subordinated to this goal. As it is well known, an important characteristic of the inner world of an artistic product, apart from the "social and material environment", "the laws of psychology and the movement of ideas," is the "degree and features of visualization, the eideticity of the artistic world which we understand as the durability and brightness of the internal visual vision of what is depicted in the work" The visual component of Samchuk's prose is surprisingly expressive and

\footnotetext{
${ }^{4}$ Мовчан Р. Привид реалізму, або проза Уласа Самчука на перетині начіональної традииії та модернізму. Українська мова й література в середніх школах. 2005. № 3. Ст. 112.

${ }^{5}$ Клочек Г. «Художній світ» як категорійне поняття. Кіровоград, 2007. Ст. 85. 
vivid covering all the diversity of the world - landscapes, interiors, portraits of characters. Due to such expressiveness, a stereo-spatial picture of being is created in which the "energetics of the artist" and the "energetics of the text created by him" pulses. That's why the nature on the pages of the novel also appears as a self-sufficient and beautiful image necessary to emphasize the myth, basic for Samchuk's prose, about Ukraine as "Terra mater" - fertile black soil, mother-breadwinner, peculiar "imago mundi." S. Barabash fairly stressed the "unusual" landscape of Samchuk which in artistic reality of his works occupies separate place for "expresses the deepest nature of Ukrainian thinking cosmism, organic integrity of individual human fate - in whole complex of tragic and beauty - into the laws of universal life"; "every landscape painting breathes with the desire of realistic painting, full sound of human life broadcasting the energy of the harmonious, reliable life existence" ${ }^{\prime}$. Nature appears on the pages of the work most often as a temple for prayer, as a source of non-coming by beauty that feeds the grain-producing soul: "What a morning! The sun, everywhere the sun, on all the peaks, on willows, on alders, on pines, on oak trees. The world is a temple, and all candles are illuminated in it"

The land of ancestors - the only thing by which the authenticity of human existence is measured - becomes in the novel (and, finally, in the writer's work as well as in his fate) the "key space-archetypal concept", the catalyst for the main problem - an existential choice.

The novel "Volyn" announced the arrival of a prose writer in Ukrainian literature with a powerful epic thinking, an artist who created a "novel structure of the new level of artistic synthesis" (S. Boroditsa) and an original author's style, over whose belonging to the discourse of either modernism or realism literary critics still discuss today. Samchuk entered the treasury of national literature by the fact that he modeled a narrative that sounds like "the natural word of an archetypal narrator" (M. Tkachuk), that is, he became the creator of a powerful metanarrative about national life.

${ }^{6}$ Барабаш С. Пейзаж Уласа Самчука як модель украӥнського пантеїстичного cвimy. Улас Самчук: художне осмислення української долі в XX столітті. Зб. наук. праць за матеріалами Всеукр. наук. конф. (11-13 травня 2005, Рівне - Дермань Тилявка - Кременець). Рівне, 2005. Ст. 175. 
In Samchuk's style, despite a significant proportion of journalism, come the features of renewed realism characteristic of, for example, the Polish literature of the 1920s, in which the center of gravity shifted from the object to the subject which clearly led to the deepening of psychologism. The tendency to combine realism with the elements of modernism in the author's stylistic modification is emphasized by V. Shevchuk, R. Movchan, Yu. Polishchuk, Yu. Marynenko, S. Boroditsa. However, M. Moklytsia's argument about the creative method of Samchuk also seems to be quite apt: "...it would be strange if the writer, being in the epicenter of the development of modernism, wrote his prose based on examples of old-world Ukrainian realism. No realist of the twentieth century escaped the influences of modernism. But the dominant determines the adherence to the method: Samchuk has never been so subjective in order to subjugate himself an object",

Genre and composition structure of the novel is largely motivated by the narrative strategy of the work: the comprehension of the events of the epoch takes place through the prism of the world perception of individual characters which at the narrative level is influenced by the model of the narrator-protagonist who evaluates and interprets the events. In "Volyn", this narrator is as close as possible to the author himself; this is how the level of autobiography is determined. It should be emphasized that Samchuk applies stylistic constructions in which the character is given the freedom of expression. In addition, the work is clearly polyphonic - "the polyphony of the novel is developed so skillfully that it really resembles the symphony with dozens, hundreds of voices each of which leads its part, integrates its small story into the general picture of life" ${ }^{\text {. }}$.

The next novel of the writer - "Kulak (Fist)" - confirmed the affiliation of Ulas Samchuk's prose with the Dontsov's paradigm of Western Ukrainian and emigrant literature and testified to the further author's searches on genre and style terrain. If "Volyn" has clear signs of

\footnotetext{
${ }^{7}$ Моклиця М. Метод і жанр роману У. Самчука «Волинь». Улас Самчук: художнє осмислення української долі в XX столітті. Зб. наук. праць за матеріалами Всеукр. наук. конф. (11-13 травня 2005, Рівне - Дермань - Тилявка - Кременець). Рівне, 2005. Ст. 154.

${ }^{8}$ Моклиця М. Метод і жанр роману У. Самчука «Волинь». Там само. 
an epic novel, then in this work, whose name appears to be an ideologeme which clearly, even provocatively and frankly revealing the ideological and worldview positions of the author, Samchuk departs from the chosen by him the wideness of epic thinking of his previous novel and experiments with genre form. Researchers rightly say about the "exit out of the boundaries of the novel invariant which was due to the main structural factor of the novel by U. Samchuk - "openness", the synthetic nature of the genre. The structure of the novel "Kulak" by its aesthetic and semantic field encompasses the socio-psychological novel with the elements of a novelist, adventurous and ideological genre variety. This is a structurecomplex and original in form of formation which confidently confirms the creative and innovative possibilities of a realistic novel of the twentieth century"'.

In fact, the first part of the novel consists of novel sketches resembling a sketches made with coal, - black and white, without plastic roundings, portrait-sketches of those colorful figures who the central protagonist of the work, Lev Boichuk, met in the prison cell. There is a chronotop of the road through the novel (it is a peculiar compositional axis of the work) which begins at the intersection outside the village, from where Lev started his life journey - first orienting himself eastward to the border of the great and unknown, but the dreamed state in which the peasant son would have the right to study, the right to win his place in life as a particle of a great nation. From the hard labor in that dreamed state, which in fact was a great prison for the peoples (as Lev learned from the fugitives from the USSR in Polish prison), Boichuk (as ultimately once Samchuk himself) was rescued by the arrest on the Polish border. The path to the east was not the broad road that the character had dreamed of - instead of the "beaten path" - the roundabout ways. Moreover, in the system of artistic images of the novel, such a transformation is clearly and distinctly emphasized: "They went outside the village: beaten way. Not beaten it is now. Overgrown with

${ }^{9}$ Бородіца С. Кониептуальний погляд на романістику У. Самчука в контексті прози його доби. Бородіца С. Концептуальний погляд на романістику У. Самчука в контексті прози його доби. Улас Самчук: художнє осмислення української долі в XX столітті. 3б. наук. праць за матеріалами Всеукр. наук. конф. (11-13 травня 2005, Рівне - Дермань - Тилявка - Кременець). Рівне, 2005. Ст. 129. 
knotweed, weeds, it leads to a closed border serving yet unenviable service of the field road. There had passed his past... Events trampled him with a sharp sword like a thread". Lev had to go his life-way through the walls of cell No. 12 after understanding of many problems that had previously been perceived by him from the empty chants of the Bolshevik agitators. The unusual people from prison, each of whom passed his Calvary, helped Lev to liberate himself from stranger's ideology. The determining influence on Boichuk was made not so much the stories of Yordanov about the "terrible GPU", but his palms beating by the drunken sailors in the walls of the same GPU.

Ultimately, old Shabelian helped Lev to fully understand the deep nature of his bread-making nature, in the nature of which it was strange doing nothing and the attraction to "strikes" and "demonstrations". While listening to the story in almost inferior in his remoteness from the cruel and dirty prison reality of Shabelian about his deep and painful love for the earth, which requires a person to give himself all to the labor, Boichuk begins to realize that powerful spiritual core that is the axis of his own breadmaking soul.

Ulas Samchuk, by no means accidentally and not as a tribute to the fashion, took an epigraph to his novel lines from Nietzsche. After all, the whole novel is about the formation and quenching of the will and the action of the central protagonist.

The second part of the novel is the path of Lev Boichuk to success marked by the desire to bring his own life's achievements to the benefit of the nation even if he has to sacrifice his personal life for this purpose. Work becomes overwhelming passion of Lev. He feels himself the master on this land, feels responsible for it, that's why he is determined not to allow it and his own people to be robbed "by the millions of outcasts who came from all over the world to make profit from the helplessness and misfortune of the local people". It is no coincidence that the novel ends with the image of the forest road where goes old Shabelian. It is those ones like he, the proprietors, "the salt of the earth", who will become the foundations of that grandiose nation-building business which Boichuk had planned. The road leads this time not to the roundabout way of someone 
else's "Fata morgana", not to the gray striped border posts, but to the magnificent, dreamt by Shabelian's imagination, field - to their own happy destiny.

The novel "Kulak" by Ulas Samchuk sought to answer the painful issues of time about the historical fate of Ukraine and its purpose, to show the birth of new Ukrainian person - the active conqueror of life, who does not limit the activity with the framework of the little homeland, but is ready to actions in the name of his/her nation, Ukraine.

Ulas Samchuk also told about the people's fate on the example of the fate of individual in "Mariia", a novel that is close to the genre of novella. The welcoming space of the novel is marked by the first smile of little Mariia and ends with the last beat of her heart, tormented by hunger and grief. The iconographic "drawing" of a mother with a baby near her chest, with which the novel begins, is not accidental: thanks to it, the ideological vector of the work from the first pages is steadily directed to the transcendence - the author, narrating "labor and days" of Mariia, her suffering death, tells the world about "God's Mother, killed by artificial famine in Ukraine in the thirties" (Yurii Bezkhutryi).

The problem range of the novel is extremely rich: here we have the eternal problem of human happiness, in Samchuk's version of which disclosure is echoed by Skovoroda's guides and the "philosophy of the heart", the problem of life choice - the active control of his/her fate or quietism, the problem of love and betrayal, national consciousness and mankrutstvo (loss of historical memory), the problem of invasion of the terrible bacilli of ideology which is alien to Ukrainian mentality, antihuman desolating soul and the earth, and confrontation with it by the power of spirit. In the image of Mariia, the author embodied the best features of the earth mother, Ukrainian woman. Far from idealization, it appears in the full-fledged artistic image of a person who seeks happiness and fights for it - she struggles with love and labor. The life of Mariia before the coming of the terrible, dark force that destroyed everything created by her labor and love, the Russian horde, was not easy: the girl was orphaned early and had to work. However, in this life there was God's blessing, there was the icon of the Mother of God, - the only inheritance 
from the deceased mother. This image becomes her "permanent spiritual support", she believes that the patronage of the Holy Mother will save her family, give her strength and faith. Ulas Samchuk shows the forgiving and all-conquering power of love that can create miracles. It was Mariia's love that changed the careless heart of Kornii, his stubbornness and the bad habits he had earned in his seven years of service in the Russian navy (neglect of the native language, laziness, cruelty). This powerful force turned Kornii back to his deep essence of the farmer and the owner, forced to throw off the shell of brutal Moscow cynicism, to feel again the joy of work and being on earth. The inner world and the behavioral model of Samchuk's characters defines vitality as an ethnopsychological constant of perception of life; it is manifested at the level of micro- and macro- images of the work, is echoed in intonations of strict and dry voice of the narrator; in the end, it becomes a philosophy of the work. The triumph of life is asserted in the novel in the descriptions of the echoes of the fields, branches of trees burdened with fruit, sun rays, caressing the earth and people, the smell of fertile black soil. Samchuk "paints" with a word, his landscapes are saturated with the vital force, the pulsation of life, the presence of the Creator.

Myth-making is involved in the author's inner structure of the novel not only in the modeling of Ukrainian cultivating space with an emphasis on the cult of family, labor, and maternity. In our view, it is the strength of the spiritual confrontation with the all-consuming darkness of the antihuman nature of the modern empire, the force found by the main characters of the work - Mariia and Kornii, their love for peace and life, the vitalistic determinism of characters, becomes the core of the renewed Ukrainian myth, paralleled by the Dontsov ideology of active act.

Ulas Samchuk with strict documentation of the "chronicler of difficult times" shows the tragedy of the Ukrainian village, the tragedy of the destruction of Ukrainian space, the tragedy of Holodomor. Maksym returns home "in the Bolshevik skin," who did not love neither land nor labor since childhood. Terrible bacillus of the new faith was easily absorbed in his empty soul: Maksym was a lumpen, and the revolution gave him the opportunity to draw the fate of others. The first thing that the "prodigal 
son" congratulated his native house and mother was "Took the gun, shot once and Kyiv icon was scattered into pieces." This terrible episode in its deep essence is not merely a demonstration of the atheism of the eldest son of Kornii. At the level of the symbolism of the work, it testifies to the fracture, the deep "tectonic shift" of a monolith of a nation, a monolith, which always held on the strength of spirituality - the world of the Ukrainian peasant was the world of Christian values. Alien "gods" - Marx and Lenin - replaced Christ's teaching by the bacchanalia of the bloody idol. Shooting into the image of the Mother of God, Maksym shoots into his family, his roots, into his future denying it. He brings a sacrifice to the bloody god's revolution (let's recall the character of Kosynka's novella, who in the drunken times shoots into the icons), eventually reborning from the human likeness (albeit insignificant) into the newest Hohol's devil. No wonder the mother thought that she was shot by Maksym. The symbolic dream of Hnat, as evidenced by the strictly restrained intonations of the narrative about the tragedy, reveals the Satanic essence of the invading soul of the lycantrope - the true "oprichnik" of Bolshevism, Maksym will abjure his parents, give his brother out, exterminate the village with famine.

Having described the tragedy of an artificial famine in Ukrainian villages, showing the terrible, martyrdom of grain farmers robbed from the last grain, Ulas Samchuk also testified to the strength of their spiritual confrontation with the satanic authorities. At the heart of this power is love as the supreme imperative of Christ's commandments. Mariia tries to save the most valued people for her; and her heart is still beating with the thought about her daughter and little granddaughter. Hnat's love for Mariia, the perception of her suffering and the suffering of many Ukrainian mothers as the suffering of the Mother of God makes Hnat forget about the value of his own life. In the lifetime achievement of Kornii, the love to everything native and loved becomes a decisive factor in the act of justice, which he carries on at his son-apostate. The image of Mariia - the Ukrainian mother-sufferer - is raised by the author to the symbol of Ukraine and the symbol of the Virgin also due to the skillfully discovered genre form. "Mariia" is a work of powerful tragic sound, it is also a hymn 
to life, love, and requiem for millions of Ukrainian mothers, parents and children, destroyed by a terrible totalitarian system. This is a blaming on the Satanic policy of the Kremlin in the face of history and evidence of the terrible death by hunger of children of the earth, farmers the last crumble of bread of whose hands was pulled out of. And at the same time it is a highly artistic novel in which the problems, composition and image system are caused by a high ideological inspiration, woven by the living nerves of a powerful spiritual energy, and create a single flesh of the perfect artistic work. It is not by chance that Samchuk chose to "chronically" form of the composition for the purpose of realizing his thought, thanks to it, the work resembles the genre of the "live" literature.

\section{Novelistics of the writer as a source of comprehension of the specificity of his artistic thinking}

An important page in the creative work of Samchuk in terms of understanding the specifics of his artistic thinking is the resort to the genre of the story. Collection of his little prose "Paradise found" appeared in 1936 in Lviv. Novellas and stories, written in a foreign country, created the illusion of the "found paradise". The collection includes nine works, impressionistic "blurriness", the mood of which are combined with ethnic and psychological paradigm as plot creation factor which manifests itself both at the level of macro and micro images (in particular, the tropics) and at the ideological level. "Paradise found" by U. Samchuk creates a symphony of moods, impressions, among which the dominant one is nostalgia. The works included in the collection are uneven in artistic and ideological levels. Although here the impressionistic style of writing prevails, in the narratives there are also features characteristic of the romance of vitaism ("In a fair way") and sometimes - naturalism. The stylistic features of expressionism, naturalism and impressionism are combined in the novel "In the Courtyard", the impressionistic ornamentation is intended to reveal the fear of death; because the death of the character of this work is horrible, with its senselessness, especially considering the background of the sacrificial death of the protagonist of the novella "In a fair way", who fell because of "some stranger's bullet, on 
their own grain fields." In the "Broken Goddess", the image of Lida, as well as the image of a multicolored autumn, is "osontsenyi" (brightened by sun) by Tychyna's "clarinettism". The acutely ironic work "Avs-Finn" is devoted to the theme of emigration. In the center there is the image of a limited emigrant-coward who continues the gallery, initiated by V.Samiilenko's "patriot". The same ironic notes sound in the short story "Paradise found". If for the character of "My Autumn" this paradise is lost, because on the map, where he looks every night, he sees "a blue bird with a broken wing", he sees his harried homeland, and then a successful lawyer found his paradise after emigration - near the full trough. The main motive of the collection is the motive of grief over the homeland. At the same time, it is an intertextual leitmotif of all prose by U. Samchuk and even the life of the artist. "The life of his soul" becomes expressive and emotional basis of creativity defining the subject and figurative structure.

Organic connection with the historical fate of the people, the desire to "include" the chronotop of the homeland into the emigration routines, filling them with the meaning, also explains such a compositional feature of the novellas of the writer as "double spacing" (i.e. the presence of "event" plot part which deals with an emigrant life and a "visionary" part which is a memory of Ukraine and carries a basic ideological focus). Indeed, it is there, in the visions, in the memories of the "motherland" sprout the magic grains of the "found paradise". Such feature of the composition motivates the specifics of the time-spatial continuum of novels by U. Samchuk: the contrasting wedge into the chronotop of the time coordinate of the past, important and meaningful sense even in details. The novellas of the master are characterized by the presence of internal monologues, lyrical shifts, visual images, artistic details.

In 1943, the writer traveled to Halychyna (Galicia) (town of Horodok near Lviv). Here he completely devoted himself to creativity. The collapse of hopes for Ukraine to acquire statehood and the foreboding of the fate of the exile prompted him to turn to the origins of his own youth and the times of his studies at the Kremenets Gymnasium. The 1944 novel "Adolescence of Vasyl Sheremeta", which was honored in 1944 contest by the Ukrainian Publishing House in Lviv, was published in Germany three 
years later. The range of problems raised here is outlined in the third volume of "Volyn". U. Samchuk speaking about the gymnasium year of the peasant son Vasyl Sheremeta, who largely resembles Volodka Dovbenko and the author himself, sought to show the formation of a new generation of Ukrainian intelligentsia. The work attracts readers with its bright and lively images of gymnasium students, lyric indents, colorful descriptions of Kremenets and its surroundings. However, the literary critics are rightly observing certain creative and ideological crisis that has affected the artistry of the novel: "...taken to the emigration "Volyn luggage" ceased to be a source of inspiration for the writer, he needed a new vital facts, new impressions" $"$.

\section{The novel "Ost" as a practical embodiment of the concept of "great literature"}

While being in Germany, the writer was an active participant in Ukrainian social life in the circles of emigration. His name is associated with the creation and operation of the MUR (UAM, i.e. Ukrainian Art Movement). U. Samchuk also embodied the concept of "great literature" in his own writer's practice: he began to write a monumental novel in three books ("Ost") whose work lasted about four decades. The first book, "Farm of Morozy," was published in 1948 in Regensburg, the second part, "Darkness," appeared in Canada in 1957, the third one, "Escape from oneself," as long as in 1982.

Trilogy "Ost" is the Ukrainian chronicle of the terrible days with the cruelty, full of struggle of different ideologies, good and evil. Through these tests pass not only his characters, but passes all Ukraine, its cultivating soul. In the first book of the novel, the historical background of which was the time of the national liberation struggle in Kaniv region, it tells about the farm as a paradise of earth, as a fortress of Ukrainian existence. The author not only showed the village life as the most organic for the "soil race" echoing this with "farm philosophy" of P. Kulish.

${ }^{10}$ Мариненко Ю. До проблеми концепції людини в романі У. Самчука «Темнота» Улас Самчук: художнє осмислення української долі в XX столітті. Зб. наук. праць за матеріалами Всеукр. наук. конф. (11-13 травня 2005, Рівне -Дермань - Тилявка Кременець). Рівне, 2005. Ст. 133. 
He, with the right remark by R. Movchan, artistically embodies the "archetypal myth" of the Ukrainian farm, "as a kind of ethno-cultural civilization generated by the mentality of the nation," an archetype that "has always been the epicenter of his worldview and artistic universe"11.

Epicity prompted U. Samchuk to comprehend a person in new historical space and time. One can say that for the novel "Ost" the "Ukraine-centric" chronotope is however associated not with Kyiv, but with Kaniv: such "reaccenting", based on the epistolary and memoirs of the writer himself, is explained by the "energy field of Chernecha Mountain" (Y. Lavrinenko). It was in the "Chernecha Mountain energy field" that author located the family farm of Morozy which makes the microcosm of the Ukrainian family organically part of the sphere of the spiritual field of the nation creating a vertical of the tradition. In the family nest of Morozy ecerything is important, the smallest detail here is full of deep meaning, irradiated with the warmth of memories, it carries the lifegiving energy of generations. U. Samchuk reconstructs "cultivated by the literary tradition myth of Ukraine as a luxurious fertile land, calling it farm of Moroz"12 while at the same time embodying his "amazingly consistent attempt" "to write the arch-work about Ukraine" the main characters of which would have been to be represented by "central Ukrainians".

In the "Farm of Moroz", the turbulent turnout of events almost does not affect the family that lives in a patriarchal life. At one time, it gave grounds for O. Hrytsaiev and L. Lutsiv to name the first volume of the novel as a work about "holidays in Ukraine and a bit about the revolution", and D. Dontsov to see in it "the whole anthem in honor of gluttony and chewing jaws." However, in the holistic perception of "Ost," rich in descriptions of the feast, "Farm of Moroz" is perceived much deeper. After all, excessive, at first glance, the immersion of characters in the bodily, material in reality is firmly connected with the spiritual. The harmonious man of work, who can fully enjoy life, radiate creative, life-giving energy,

11 Мовчан Р. Проза Уласа Самчука на перетині національної традииії та модернізму Улас Самчук: художнє осмислення української долі в ХХ столітті. Зб. наук. праць за матеріалами Всеукр. наук. конф. (11-13 травня 2005, Рівне - Дермань Тилявка - Кременець). Рівне, 2005. Ст. 56.

${ }^{12}$ Мариненко Ю. Там само. Ст. 133. 
the author contrasted the world of fanatics who hate the "material" as "private property", hostile to the new world, create a utopian "paradise" under the projects of hell and seek to feed millions with the idea. Yet, the "inclination to corporeality", the passivity and the standpoint of waiting is a fatal mistake of Moroz family (after all, of Ukraine as a whole) in the whirlpool of the events of the national revolution. After publishing the novel "Farm of Moroz", I. Koshelivets, giving the product a high degree of appreciation, expressed the rejection of certain aspects of the historiosophical concept of the author - the remarks concerned, first of all, the falsity of the historiosophical concept of the revolution as "some absurd rebellion". However, the author himself did not agree with such an interpretation. In the "Farm of Moroz", one can really feel the author's somewhat ironic attitude to revolutionary events, including the national revolution - since the psychology of the owner, the worker, is cautious and mistrustful of any social unrest that leads to ruin and famine. Still, there are active participants of the liberation events - Vodianyi, a friend of Moroz family, and sister Tania - belong to the part of Ukrainians who with arms in their hands opposed Bolshevism.

In the next part of "Ost", U. Samchuk did not accidentally put in the mouth of the leader of "all working people" a clever replica that reveals the true essence of the policy of "proletarian unity" of Russia and Ukraine as well as perpetuates certain aspects of the writer's historiosophy: "Petersburg was built by Peter on their bones, he says, and I will build the socialism of the whole world on my bones. Not one, he says, tribe is as useful for dung as khakhly... Everything grows very well on their corpses... Empire, Petersburg, Leningrad... Revolution. If, he says, they supported Petliura as Pilsudski was supported by the Poles - there would not be the USSR today. But they did not do that. And now we have enough dung for collectivization"13. The novel "Darkness" testifies to the evolution of the writer's world outlook, reveals his historiosophical conception of the Ukrainian revolution.

Leading their characters through the roads of severe trials, the writer has raised a number of important historiosophical problems, including the

${ }^{13}$ Самчук У. OST. Трилогія. T. 2. Темнота. Тернопіль, 2006. Ст. 380-381. 
problem of totalitarianism. The author derived the formula of the savagery and destructive energy of the Bolshevik ideology from the mentality of the "Moscow people" crippled in the time of Ivan Groznyi. In the novel, "Darkness", the complex challenges were depicted, which fell on the fate of all the members of Moroz family during the time of total rule of evil. However, parts of the trilogy in the artistic plan are uneven: departing from voice of the nation-wide narrator, the characteristic for "Volyn" and "Mariia", replacing him with the all-knowing narrator, U. Samchuk is more clearly drawn to journalism. In addition, the integral image of Ivan Moroz, who in the first part of the novel represents the best features of the Ukrainian character, is the embodiment of the harmony of the bodily and spiritual, the bearer of a powerful creative energy, undergoes a certain transformation. The eldest of the brothers is a true master who hurts to see how human labor is destroyed, how the land, made with the hands of former owners, is getting wild. For him, labor is an organic need and a natural state. Good economic and leadership abilities of Ivan are the reason for his new arrest. Moroz is in Lukianivka and later - in special purpose camps in Ust-Pechorsk. And here the fate of Moroz really undergoes an unlikely metamorphosis: the highest party leadership appoints political prisoner Moroz as "chief head of all Ukht-Pechorstroi". The writer has his own, in his opinion, rather convincing and plausible motivation for such a paradox: no matter how the true Marxist-Leninist ideology converts would have sought to destroy Ivan, yet the system cannot do it without him yesterday's pig farms and proletarians were only trained to destroy. "Constructivism", "unlikelihood" of Samchuk's character, squeezed into the framework of the author's concept, caused in its time sharp reaction of Yu. Lavrinenko who accused the artist not only of moving away from the truth, but also of anti-humanism. There is a certain part of the truth in this observation - U. Samchuk is so admired with the economic skills of Moroz, his "life-positivism", that he shifted the emphasis from the Solovky hell to transforming into a "civilized business land of the wild jungle of the north" (Yu. Lavrinenko). Yet the accusation of the writer in anti-humanism is unfair: depicting the Siberian "epic" of his character, the author panoramically captured the terrible empire of the camps, which was raised 
by the Soviet authorities. "Hell on earth" - this is how this empire of evil rule was called by Yurko Yurchenko, a contemporary of U. Samchuk. And although the writer himself was fortunate enough not to be abused by the Soviet concentration system, he was able to reveal the principle on which it was held and the dominant "strategy" of the "great architects" of the empire since the times of Ivan Groznyi and Peter I, during which the swamps were mounded with the prisoners, and on their bones the "structures of age" were built; a strategy that put the sign of equality between the world-renowned academic and recidivist, the Ukrainian farmer and yesterday's executioner - chief investigator of the GPU.

From the GULAG camps to "Buchenwald" - such is a range of comprehension in the novel of the cause of evil that is carried by a totalitarian system - no matter who "sterns" it: Stalin or Hitler. The third book of "Ost" describes the occupation policy of fascists in Ukraine, the policy of the conquerors, which differs little from the policy of the Bolsheviks, the hard fate of many Ukrainians exported to Germany, the tragedy of their forced repatriation in the USSR. U. Samchuk's scale of epic thinking enabled the creation of a panoramic picture of the period of the Second World War and those changes on the map of Europe, which took place as a result of the Yalta Conference. However, the magnitude of the novel lies in its "all-planetary" issues: political, philosophical, and ethical (Yu. Bezkhutryi).

Samchuk, for the first time in Ukrainian literature, told the bitter truth about the triumphant campaign of winners in Europe. The mistreatment of the repatriates, shootings, arrests, insults and humiliation is what awaits yesterday's "Ostarbeiters" in the territory occupied by Soviet troops. Therefore, the only correct thing in this revenge of evil and violence is escape from hell, although it is at the same time escaping from oneself. Ivan Moroz, who at first decided to return home naively hoping that things will change now, is the one who sees the possibility of emigration precisely as the fleeing from oneself.

The third book of "Ost" is also a work on the "crystallization of the spiritual image of Ukraine" (I. Rusnak), a homeland that has been preserved in the hearts by the "non-returners" and a part of which has been 
taken by them overseas. And with god reason the novel ends with the episode of the meeting of the Moroz family - Ivan, his wife, daughter Vira, son-in-law, and grandchildren - on a Canadian farm - a farmstead built by Ivan on a new land. It is precisely in the episode that "the broad idea of the prose writer-epic is objectified and textualized" and the pathos-idea of the work that "disperses from the spiritual world" of the artist himself (R. Hromiak) is revealed. The author himself had the fate of the emigrant: his wife and he, sailing on September 23, 1948, on board of the "General Stewart" ship from the Bremen port to the far coast of Canada, took with them the most expensive - the spiritual image of their homeland.

\section{CONCLUSIONS}

In Canada, the artist joined the writer's forces in emigration. He is one of the founders of Ukrainian Writers Association "Slovo" ("Word") created in New York on June 26, 1954 (the charter was adopted on January 1, 1957). U. Samchuk also did not abandon literary work: the memories of war years gave an impetus to the novel "What fire cannot heal" (1959). The main character, Jakiv Balaba, finds his life mission as the commander of the partisan detachment "Ohon (Fire)". Conscious of the doom of the national liberation struggle, he refuses to flee to America, and cannot agree on cooperation with the Germans. And although the day "systematically destroys the myth of the heroes" (Y. Polishchuk), yet one day, just when Jakiv and his friends "fell out of the carriage" of the train, which sent "ostarbeiter" to Germany, a new hero is born - the partisan leader, Troian. The dominant in his character is the dominant of will that gives grounds to talk about "a peculiar correction of the author's biographical experience" (Y. Polischuk).

Constantly being in a whirlwind of social and cultural work, U. Samchuk continued to work fruitfully as a writer. The separation from the homeland, nostalgia and anxiety for the future of Ukraine, as well as a firm belief in its future, encourage the artist to turn to the experienced, to comprehend his own life experience in the background of the epoch. The spiritual image of Ukraine as a powerful life-giving force that inspires the work and creativity of its children along the ocean, fills them with faith and 
optimism, is present in the novel "On Solid ground" which was published in 1967. The novel captures with the heady scent of freedom of selfawareness and self-expression, creative inspiration with which yesterday's fugitives from a totalitarian empire build their lives. In the center of the novel is the problem of comprehending the "non-returners" - Pavlo Danyliv and Lena Hliders - their new homeland as a solid, reliable soil, sprouting and crystallization in it of the spiritual image of Ukraine. In the past Kharkiv, hungry and terrorized by the repressions, parents repressed as "enemies of the people" or foreign intelligence spies, the gloomy shadow of the hungry 1930s. The future is on a solid ground and everyone is free to build themselves on his or her own: Lena realizes herself as a talented artist, Pavlo dreams of writing creative work and at the same time is fond of building his own home. U. Samchuk with pleasure describes buildings, parks, gardens, alleys, because all this are the signs of residence, reliability. These are signs of a good farming system, of creativity as one of the main features of the Ukrainians.

The creative work of U. Samchuk, the epic nature of his artistic thinking, the significance and general human relevance of the problems raised in the works put the Ukrainian writer in line with the most prominent European artists of the twentieth century. U. Samchuk believed in the future of Ukraine as a state, in the fact that "darkness" dissipates, and at least his word will return to his homeland, nebula will fall from the eyes of millions - and it will tell them the truth. All creative work of the artist is the artistic embodiment of this faith, his historiosophical ideas, for which no force is able to deny Ukraine and Ukrainians, because "we are in the pulse and the rhythm of the earth, in its cosmic cycle, and no one has the power to drive us out there yet" (U. Samchuk). "Colossal spiritual gravity" always kept him "in the orbit of national duty" (M. Zhulynskyi). In the orbit of national duty, forever his work remained - the love for Ukraine embodied in the word. Nation-affirming, nation-consolidative idea pervades the national metanarration created by the artist, establishes the most important spiritual values that determine the depth of the mentality of the nation and the foundations of humanism. U. Samchuk developed the best traditions of realistic Ukrainian literature in an updated philosophical 
realism, but in the "force field of modernism" emphasizing the philosophical problems of human existence in the dimensions of history and eternity.

Writing work by U. Samchuk and public activity forever belong to the paradigm of the Ukrainian reconciliation - the "welcoming model", which aimed primarily at the spiritual affirmation of Ukraine "by creating a credible forespace - the magic of texts" (N. Zborovska). This idea is subordinated to Samchuk's emigration concept of the "grand literature", which echoes the Dontsov's idea of passionarity, the heroism of action: "The word, once sown, goes into the action". The patriot-writer considered the main task of Ukrainian artists in emigration to be the creation of "the literature of such a measure and a style that could raise us in the eyes of ourselves and the eyes of the rest of humanity"14. The whole stratum of creativity by Ulas Samchuk is an artistic embodiment of his faith in the future of Ukraine, his historiosophical ideas.

Creative work by U. Samchuk as well as his contemporaries Yu. Lypa, L. Mosendz, H. Zhurba, N. Koroleva - during the interwar period, corrected by the moral and ethnogenetical imperative, has become the embodiment of truth of the era, witnesses and parties to which they were, and the truths of the previous ages and generations of the Ukrainian nation. It is in the individual author's styles of the named prose writers marked by the dominant of individual artistic thinking and dominant of time, aimed at both understanding the "dialectics of the soul" of man and the "dialectics of the spirit of the era," of the idea of "great style," which after the Second World emigration took shape in the concept of "great literature", found its embodiment.

The motivational foundations of works by U. Samchuk, that eliminate the level of dominant and ideal, reveals direct correlation of the direction of artistic thinking and orientation of writer's personality in coordinates of ontologically-existential dimensions as an active conqueror of life a passionarian. And the direction of artistic thinking of the creators of "authoritative style" directly correlates with the orientation of their

${ }^{14}$ Самчук У. Ідейні мотиви моєї творчості. Роздуми про літературу: збірник літературно-критичних статей / упоряд., примітки, післямова М. Я. Гона. Рівне. 2005. Ст. 20. 
personality - first of all - as passionarians whose main creative goal is to create a "state of word", the struggle for the establishment of a national identity, and is also characterized by panoramic comprehension of events and moods of the epoch.

\section{SUMMARY}

The paper analyzes the work of Ulas Samchuk, one of the iconic Ukrainian writers of the twentieth century, at the angle of the projection in his prose of the "philosophy of action" whose ideological dominantes crystallized in the journalism of Dmytro Dontsov and found a daunting embodiment in the practice of Ukrainian prose writers of the interwar twenty years in Halychyna (Galicia) and in the diaspora. This philosophy actively opposed the spiritual occupation of Ukraine by the Stalinist regime. The definition of the category of "authoritative style" wasi also ntroduced in the literary tradition for the first time by M. Bakhtin as "the key to the epoch" and applied to the analysis of the poetics of Dostoievskyi is also given. The category offered is in some way resonant with the category of "participant poetics" defined by V. Derzhavin in a number of his works devoted to the poetics and style of Ukrainian diaspora literature.

The crystallization of the "authoritative style", transforming the problem of the interaction of subjective and objective principles in the process of creating stylistic forms, gave birth to new types of relations between the material of life and the writer's artistic thought, new forms of style activity.

The "authoritative style" of Western Ukrainian and emigration prose was created by the bright facets of author's styles of artists, whose individually artistic thinking is marked by the organicity of artistic vision and expression as an original artistic system, and the "expressive system" of these artists' prose is determined by the dominant moments of the writer's orientation and the target directions of the artist as a person, in the first place - by the passionary impulses, activity under the sign of a high purpose. The purpose for these artists was to preserve the spiritual Ukraine from assimilation with the Soviet regime. Ulas Samchuk's prose, by a powerful narrative, rooted in a deep national tradition, regenerates 
Ukrainian space as a space of grain production nation from the chaos of the modern (Soviet) empire. Samchuk appears as the creator of a narrative form, actively developing the principles of subjective multiplicity of narrative enriching this system with a variety of character plans. In the center of Samchuk's Volyn "saga" is the national Ukrainian space, whose model is the Dovbenko's farm and the history of the Ukrainian family as the main link of the Ukrainian ethnos.

And Ulas Samchuk's novel "Kulak" and a collection of his small prose "Discovered Paradise", the imagery of which, as proved in the paper, is also based on the archetypal basis of Ukrainian mentality, and the trilogy "Ost" is his concept "great literature" embodied in the work of the writer, which raises a voice in defense of the enslaved and torn people, restores spiritual values that have been swept away by totalitarianism, establishes faith in the revival of Ukrainian statehood.

The motivational basis of the work by U. Samchuk, which eliminates the level of dominant and ideal, expresses a direct correlation between the orientation of artistic thinking and the direction of the personality of the writer in the coordinates of ontological and existential measurements as an active conqueror of life - a passionarian. And the direction of artistic thinking of the creators of "authoritative style" directly correlates with the orientation of their personality - first of all - as passionarians, whose main creative goal is to create a "state of word", the struggle for the establishment of a national identity, and is also characterized by the panoramic comprehension of events and mood of the epoch.

\section{REFERENCES}

1. Барабаш С. Пейзаж Уласа Самчука як модель українського пантеїстичного світу. Улас Самчук: художне осмислення української долі в XX столітті. Зб. наук. праць за матеріалами Всеукр. наук. конф. (11-13 травня 2005, Рівне - Дермань - Тилявка Кременець). Рівне, 2005. Ст. 172-178.

2. Бахтин М. Проблемы поэтики Достоевского. М., 1963. 363 с. 
3. Державин В. Стиль і стилізачія ("Украйнська еміграџійна література (1945-1947”) Нариси з поетики: Теоретико-методологічні та історико-літературні виміри. Івано-Франківськ, 2008. Ст. 142-175.

4. Бородіца С. Концептуальний погляд на романістику У. Самчука в контексті прози його доби. Улас Самчук: художнє осмислення української долі в XX столітті. Зб. наук. праць за матеріалами Всеукр. наук. конф. (11-13 травня 2005, Рівне Дермань - Тилявка - Кременець). Рівне, 2005. Ст. 129.

5. Державин В. Література $і$ літературознавство: вибрані теоретичні та літературно-критичні праці. Івано-Франківськ, $2005.492 \mathrm{c}$.

6. Донцов Д. Дві літератури нашої доби. Львів, 1991. 295 с.

7. Клочек Г. “Художній світ” як категорійне поняття. Кіровоград, 2007. - С. 73-102.

8. Лущій С. "I цุе добре, щзо ми обмінялися поглядами на речі": про один епізод з історії творчих взаємин Юрія Лавріненка та Уласа Самчука. Улас Самчук: художнє осмислення української долі в $\mathrm{XX}$ столітті. Зб. наук. праць за матеріалами Всеукр. наук. конф. (11-13 травня 2005, Рівне - Дермань -Тилявка - Кременець). Рівне, 2005. Ст. 81-82.

9. Мариненко Ю. До проблеми концепції людини в романі У. Самчука “Темнота" Улас Самчук: художнє осмислення української долі в XX столітті. Зб. наук. праць за матеріалами Всеукр. наук. конф. (11-13 травня 2005, Рівне -Дермань - Тилявка Кременець). Рівне, 2005. Ст. 131-139.

10. Мафтин Н. Етнопсихологічна парадигма як основа новелістичного мислення Уласа Самчука. Улас Самчук: художнє осмислення української долі в XX солітті. Зб. наук. праць за матеріалами Всеукр. наук. конф. (11-13 травня 2005, Рівне Дермань - Тилявка - Кременець). Рівне, 2005. Ст. 157-166.

11. Мовчан Р. Проза Уласа Самчука на перетині начіональної традииї та модернізму Улас Самчук: художнє осмислення української долі в XX столітті. 3б. наук. праць за матеріалами Всеукр. 
наук. конф. (11-13 травня 2005, Рівне - Дермань - ТилявкаКременець). Рівне, 2005. Ст. 50-58.

12. Мовчан Р. Привид реалізму, або проза Уласа Самчука на перетині національної традииї та модернізму. Українська мова й література в середніх школах. 2005. № 3. Ст. 108-115.

13. Моклиця М. Метод і жанр роману У. Самчука “Волинь”. Улас Самчук: художнє осмислення української долі в XX столітті. 3б. наук. праць за матеріалами Всеукр. наук. конф. (11-13 травня 2005, Рівне - Дермань - Тилявка - Кременець). Рівне, 2005. Ст. 145-157.

14. Самчук У. Ідейні мотиви моєї творчості. Роздуми про літературу: збірник літературно-критичних статей / упоряд., примітки, післямова М. Я. Гона. Рівне. 2005. Ст. 49-67.

15. Самчук У. Велика література. Доповідь У.Самчука на I з'їді Мистеиького українського руху (МУР), грудень 1945 р. Роздуми про літературу: зб. літ.-крит. статей. Рівне, 2005. Ст. 8-28.

16. Самчук У. Волинь. Київ, 2005. 632 ст.

17. Самчук Улас. Кулак. Чернівці, 1937. 216 с.

18. Самчук У. OST. Трилогія. Т. 2. Темнота. Тернопіль, 2006. $460 \mathrm{c}$.

\section{Information about the author: Maftyn N. V., Doctor of Philology,} Professor at the Department of Ukrainian Literature, Vasyl Stefanyk Precarpathian National University 57, Shevchenko str., Ivano-Frankivsk, 76018, Ukraine 


\title{
CREATIVITY BY IVAN FRANKO: PSYCHOANALITICAL HORIZONS OF UKRAINIAN-AUSTRIAN LITERARY INTERACTIONS
}

\author{
Pecharskyi A. Ya., Zymomrya I. M.
}

\section{INTRODUCTION}

The creative biographies of I. Franko, S. Zweig and S. Freud constitute rather a biography of an entire era, the division into periods of which goes far beyond the chronological limits of the Austro-Hungarian Empire than the biography of individual writers and psychoanalysts.

In the mirror of biographers, S. Zweig for the most part appears an "apolitical" non-Austrian Austrian with a mysterious death ${ }^{1}$, I. Franko appears to be a "revolutionary" Ukrainian patriot with a mysterious, mystical mental illness ${ }^{2}$, and S. Freud is the founder of classical psychoanalysis on the basis of which gestalt-therapy, psychodrama, cognitive therapy, all group methods of psychotherapy, and finally any

${ }^{1}$ See: Лихтенштейн И. Жизнь и смерть Стефана Цвейга глазами врача. Новости медищины и фармаџии в мире: проф. спец. изд. для врачей. 2012. № 19, 20-22.

See: Haenel Th. Psychologe aus Leidenschaft. Stefan Zweig - Leben und Werk aus der Sicht eines Psychiaters. Droste, Düsseldorf 1995.

See: Lunzer H. Renner G. Stefan Zweig 1881-1981. Aufsätze und Dokumente. Zirkular. Sondernummer 2 (Oktober 1981). Herausgegeben von der Dokumentationsstelle für neuere österreichische Literatur in Zusammenarbeit mit dem Salzburger Literaturarchiv, Wien 1981.

See: Matuschek O. Drei Leben. Stefan Zweig - Eine Biographie. - S. Fischer, Frankfurt, 2006.

See: Weinzierl Ul. Stefan Zweig, Triumph und Tragik. Aufsätze, Tagebuchnotizen, Briefe S. Fischer, Frankfurt 1992.

${ }^{2}$ See: Єфремов C. Іван Франко: Критично-біографічний нарис. 2-ге вид. 3 дод. Київ: Слово, 1926. 256 с. $525 \mathrm{c}$.

Seе: Маланюк С. Книга спостережень: В 2 т. Торонто: Гомін України, 1962. Т. 1.

See: Мельник Я. І остатня часть дороги... Іван Франко: 1908-1916. Дрогобич: Коло, 2006. 439 с.

See: Мочульський М. Одно видіння Івана Франка. Іван Франко: Студії та спогади. Львів: “Ізмарагд", 1938. С. 175-190.

See: Тихолоз Б. Психодрама Івана Франка в дзеркалі рефлексійної поезії: Студії. Львів: ЛНУ ім. І. Франка, 2005. - 180 с. 
modern kind of psychotherapy dealing with the psychic unconscious of the person are built.

I. Franko and S. Zweig conquered the epoch with their creative works, because they managed to highlight the painful problems of their time by artistic word, to make the path of "truth" but not "likelihood", to show how the fate of the "little man" becomes a world-scale tragedy. They were primarily oppressed by the contrasts of misery and wealth in society. Hence comes the strained sense of social injustice which started a conflict between the personal and the public.

Franko's "Jay's Wing" and Zweig's "Letter from an Unknown Woman" sometimes appear to be artistic illustrations of deep psychology. It is not surprising if we take into account that the phenomenological signs of the "unconscious psychic" in Franko's interpretation of the psychology of creativity ("From the Secrets of Poetic Creativity") are reasonably sensitive to innovative concepts of Freud's "Interpretation of Dreams" and to the fact that S. Zweig was a good friend of the founder of classical psychoanalysis, about whom he wrote a biographical essay ${ }^{3}$ and generally shared his views, applying them in his own writings.

The attempts to briefly characterize the common features and greatness of these three thinkers - I. Franko, S. Zweig, S. Freud - led us to the hardly hyperbolic definition as "psychoanalitical horizons of Ukrainian-Austrian literary interactions".

\section{Ivan Franko - Stefan Zweig: Analogies and Interpretations}

The great spiritualized anthems of love in the world literature were the masterpieces of Ukrainian and Austrian writers - "Jay's Wing" and "Letter from an Unknown Woman". From the point of view of psychoanalysis, these literary pieces have a different "specific gravity", but in measurements of the fundamental motive, they complement each other. In the artistic and aesthetic mirror of his character's love story, Ivan Franko is the genius of rational worldview who pus to the ground the romantic flight of emotions by the prudence of thought, and S. Zweig is the genius of the

${ }^{3}$ See: Цвейг C. Казанова; Фридрих Ницше; Зигмунд Фрейд. Москва: Интерпракс, 1990. $256 \mathrm{c}$. 
feelings of a defenseless heart in love that touches the intimate strings of elegic musical mood of the individual. On the life cross-paths of emotional and mental tensions, the Ukrainian writer showed how easy it was for a person to lose love, when one did not make any effort for that love, and the Austrian writer showed how one could not see love at all and remained spiritually blind when one inflamed the smouldering fire of passion too much. In the first case, this led the protagonist to a three-year solitary confinement; in the second one, to the spiritual devastation.

Yet, in the writings by Ukrainian and Austrian authors, the main "recipe" of spiritual healing of a human is the victory of love over hatred. In this struggle of mental elements, E. Fromm believed that any neurotic form of love is the result of alienation in which there dominates one of the basic human passions (pride, vanity, fornication, avarice, and so on) which becomes the master of the individual. This passion, - the American psychoanalyst writes, - is his idol, which he obeys, even if he is able to explain rationally and give it the most varied and consonant names ${ }^{4}$.

Indeed, either those are Franko's images-symbols of "jay's wing”, "light red dress with white spots" or Zweig's "letter from an unknown woman", "white roses in a blue vase", still their main characters (Masinno and Mariya, well-known fiction writer R., and the daughter of a poor widow) are ruled by the isolated desire to "love and to be loved" onto which they transfer all their lost hopes. Thus, a person becomes a slave of his/her own neurotic passion.

The story "Jay's wing" is more like the "Letter from an Unknown Woman" in the aspect of the genre and style composition of the leitmotif rather than in the content. After all, both the Ukrainian and Austrian authors dramatize the image of love through the prism of correspondence. Revealing both plots starts with a man's reading a letter addressed to him by an "unknown" woman. However, despite the writers' interest in the anthropology of love, there is a fundamental difference between their views: Franko depicts it as visible and passionate that achieves reciprocity; Zweig, as an invisible and sacrificial one that seeks perfection.

${ }^{4}$ Фромм Э. Душа человека. Москва.: Республика, 1992. С. 320. 
The importance of reasoning is evidenced at least by the words from the letter of a woman to her beloved; they are different in content, but they are constantly repeated throughout the text, both in "Jay's Wing" and in "Letter from an Unknown Woman". Franko's protagonist, the coddled child of freedom, asks every time: "Do you understand... me?"5, and by this, she manifests her conformist, existential-psychological setting "-to have-". She prefers to refresh their past intimate relations in Massino's memory and to "receive" something in return from them by sending the jay's wing in a letter as a symbol of only one half of her soul - love. "If there is still a spark of love for me in your heart, at least a dropping of desire to see me, this will be the force that will draw the second wing, the second half of my soul to you",

Despite the romantic pathos, Mariya does not give her lover herself entirely, but only partly - in the anticipation of reciprocity. That is why her personality is set on the mutually beneficial exchange of spiritual and material values. According to K. Horny and E. Fromm, it is the so-called commercial setting of love in the modern market capitalist society ${ }^{7}$, where it is expedient to exchange and receive, trade and consume. As we can see, only after the "vitrohoninnia" (i.e. adventures with scammer Henrys, thieves' leader Zigmund, card player Volodia, wealthy goldminer Svietlov, thug Sashko, captain Serebriakov) - Mariya learns who Massino was for her.

Instead, Zweig's protagonist does not tempt fate, does not prefer to experience love in terms of freedom and new violent emotions, does not reproach her lover, does not make him any conditions and questions, but only pours unspeakable pain and grief: "My (our) child died yesterday..."8. These lines are compositionally - like the words "Do you come/understand... me?" in "Jay's Wing" - are repeated throughout the entire work. They have a deep implication as a "unifying symbol" of the painful emotional moves of female and maternal love: "I did not want to divide myself between you and my son, and I did not give myself to you, spoilt with happiness, whose life was passing by me, and the child which

\footnotetext{
${ }^{5}$ Франко І. Сойчине крило. Твори: У 50 т. Київ: Наук. думка, 1979. Т. 22. С. 60-77.

${ }^{6}$ Франко І. Сойчине крило. Твори: У 50 т. Київ: Наук. думка, 1979. Т. 22. С. 68.

${ }^{7}$ See: Фромм Э. Душа человека. Москва: Республика, 1992. 430 с.

${ }^{8}$ See: Цвейг С. Письмо незнакомки. Новеллы. Минск: Выш. шк., 1987. С. 126-158.
} 
needed me... I seemed to have freed myself from the power of the doom forcing me to be passionate about you, since the second "you" came into existence and truly belonged to me".

Here, "maternal love" becomes mature, part of the normal "erotic love" which is far from the neurotic attachment to the object. The appearance of the child to some extent contributed to the progress of the Oedipus complex of the protagonist who, being deprived of parental warmth in childhood, fostered maternal consciousness from her own inner desire to love. In other words, a magnificent rose of love grew on the sandy rocky soil of hatred, and only sharp spikes on the trunk reminded of its difficult growth.

So, in "Jay's Wing" and "Letter from an Unknown Woman", we can see different vital reference points of love: Franko manages a commercially accumulative setting "-to have-"; Zweig chooses the existential-semantic "-to be-" (Fromm) ${ }^{10}$.

This evokes a great motivation for the "actions" of the heroines: one is like a wild jay that cannot go to the proper home shelter; the second one is a stranger who cherishes sacrificial love for a person whose "passion does not know the difference between a beloved woman and a bought woman"11.

It is interesting that at the beginning of "Jay's Wing" and "Letter from an Unknown Woman" the course of events and the concept of their compositional image are the same: both intelligent men, Massino and R., read letters from women in love on the day of their birth. Even the age of the protagonists is almost identical: Franko's protagonist is 40 and Zweig's one is 41 . This incredible coincidence is made on purpose. Perhaps the authors, choosing the mature age of the characters, tried to symbolically reveal the diverse "fullness of love". Moreover, peculiar confessional logotherapy, which is played out between the addressee and the sender, is an unmistakable instance of our lost paradise of the soul, and the metalanguage of the writers' works is the artistic image of human desire to free themselves from their own passions (original sin), in particular,

\footnotetext{
${ }^{9}$ Цвейг С. Письмо незнакомки. Новеллы. Минск: Выш. шк., 1987. С. 149-150.

${ }^{10}$ See: Фромм Э. Иметь или быть? Москва: Прогресс, 1986. 240 с.

${ }^{11}$ Цвейг С. Письмо незнакомки. Новеллы. Минск: Выш. шк., 1987. С. 155.
} 
Franko's Mariya from unmotivated excessive freedom of love, and Zweig's R. from the dependence of bodily temptations.

In contrast to the Ukrainian author, the Austrian writer makes the letter carry a sacred mystical meaning, because "the story is being told" by the already dead woman who secretly loved with her hopeless love. "But you will know my secret only at the time", she writes, "when I die, - so that you do not have to reply to me..."12.

Why does a stranger not want to hear the answer?! Because it does not exist. Just like there is no love in the corrupted heart of a person whom she hopelessly loves - even while dying. S. Zweig makes it clear that true spiritualized Love cannot materialize into earthly existence, it must die to disappear. To die so that to live in eternity! After all, Love "has overcome death by death". Is this sacrificial love of the protagonist not a symbolic moment of modification of the biblical story of the infinite love of Prophet Hosea to his wife, a prostitute, whom he loved all his life, in spite of nothing? Thus, God, in the image of Hosea, wanted to show his attitude to the people; and in the image of the prostitute, the attitude of people to Him.

On this occasion, O. Men wrote: "God, rejected and betrayed by people, suffers. Here is the immense mystery opened to the prophet Hosea. This suffering is the pain of unanswered love; it indicates a sacred duty which unites the Created and the Creator. We need Him! Is that not a miracle? Can we grasp this idea? "The deity is not suffering, suffering is a sign of imperfection, philosophers say in the confusion. No, the prophet answers them, there is Divine suffering. God suffers because of our imperfection"13.

In the aspect of specifying Zweig's story, the request of the dying stranger is penetrated with extraordinary unearthly love. The woman prefers her sweetheart to buy white roses for his birthday, which she secretly gave him each year, and put them into a blue vase.

After reading the story, R. with trembling hand puts the letter aside and for a long time sits wondering. The former evening sparkles and memories of the stranger erupted as if from the fog. It seemed to him

12 Цвейг С. Письмо незнакомки. Новеллы. Минск: Выш. шк., 1987. С. 127.

13 Мень А. История религии: В 7 т. Москва: Изд-во Советско-Британского совместного предприятия Слово, 1992. Т. 5. С. 67. 
that he had seen all this in his dream. Suddenly, the glance slips on a blue vase, and only now R. notices that for the first time in many years it was empty on the day of his birth. "He felt the breath of death and the breath of immortal love; something was revealed in his soul, and he thought about the passing of life as about a barren vision - distant passionate music" $" 14$.

This is a pessimistic note which ends the "Letter from an Unknown Woman" by S. Zweig, the work which reveals the terrible internal tragedy of a person not in the death of a child or a woman, but in the immorality of the fleeting life of the famous fiction writer R. who did not even suspect that he was a loved husband and father. So, the author makes it possible to understand for each of us: look out at the spirit of faith - perhaps love passes by you invisibly.

These words also relate to Franko's protagonists, Mariya and Massino ("Jay's Wing"), the conflict of whom, according to I. Denysiuk, "is based on the inappropriateness of their characters, psychological temperaments" ${ }^{15}$. If the image of Massino embodies a passive, cold philosophical understanding of love as a majestic natural harmony and order; for Mariya, love is, first of all, a free and effective penetration into another being. Her unhappy story with Henrys, Sigmund, Volodia, Svietlov, Sashko, Serebriakov is evidence not of a moral decline in the circumstances of life, but a passionate desire to know her love in terms of freedom, incredible feelings and adrenalin.

Mariya perceived Massino's inertia of feelings and passivity as "betrayal". She liked to call herself a jay that nested on a fir tree near a wooden hut where her beloved was resting in summer. The girl loved the bird with all her heart and for the sake of it she protected the jay's whole family. But when they were hugging in front of the hut, the jay looked at them with some kind of wise look, and at this moment the girl thought that the bird had some magical effect on her beloved and at that moment he seemed to kiss her more passionately. In the heat of jealousy, Mariya shot the jay and then lifted it up, blooded, and began to kiss while weeping.

${ }^{14}$ Цвейг С. Письмо незнакомки. Новеллы. Минск: Выш. шк., 1987. С. 160.

15 Денисюк I. Ровиток української малої прози XIX - поч. XX ст. Львів: Наукововидавниче товариство “Академічний Експрес”, 1999. С. 209. 
Massino calmed her beloved and they ate the bird for lunch, laughing. In the artistic and symbolic sense, this act is a kind of cannibalism of intimate feelings, biologization of love. Maniusia hid the bird's wings in a prayer book and never left them.

As the founder of logotherapy, V. Frankl, mentioned, "the expression of unanswered love is a manifestation not only of compassion for oneself, but also of the ugly enjoyment of one's misfortune"16. Because human "immerses in his/her tragic world of the past in order to avoid possible happiness in the future" 17 .

The last lines of the story tell that some stranger is waiting for Massino in the hallway:

"- Lady? Old? Young?

- I do not know. She has a veil. I asked her in - she did not want to go. Threw the fur. It is cold there and she sits in such a light dress, red with white spots...

- Ask her in!"18

What does a light red dress with white spots symbolize?! The splashes of emotions of free love or healing with real love? It is hard to say. Just like it is difficult to assume whether Massino and Mariya's fate would have been happy later in life. But one thing is clear: it is a "bridge" between the painful memories of the past and happy future expectations.

Finally, in the labyrinth of human emotions and mind, love paves different ways, so the image of the beloved is estimated in different ways. Here arises the question: why could Zweig's protagonist in the "Letter from an Unknown Woman" not confess R. even in the most daring dreams, taking this mystery with her to the grave?! She herself explains: "Once, when I was still a child, I saw through the gap how you gave money to the beggar who knocked at your door. You gave him the money before he had time to ask, and you gave him a lot, but you did it somehow with a fear and in haste, with a clear desire for him to leave as soon as possible; and it seemed that you were afraid to look into his eyes. I have forever

${ }_{16}^{16}$ Франкл В. Человек в поисках смысла: Сборник. Москва: Прогресс, 1990. С. 261.

${ }^{17}$ Ibid. P. 262.

${ }^{18}$ Франко І. Сойчине крило. Твори: У 50 т. Київ: Наук. думка, 1979. Т. 22. С. 93. 
remembered how fast and awkwardly, evading gratitude, you helped this beggar. That is why I have never addressed you" 19 .

It is easy to "catch" the reasoning of the heroine on the contradictions of her Oedipus complex, situation and conflict, but it is impossible to deny the interesting unexpected symbolic associations and projections - the socalled intellectualization which is a barrier to sensory perception of reality. A. Freud, in her work "Ego and the Mechanisms of Defence", drew attention to the specifics of intellectual activity of humans in their early age. Logically, one would have to weaken intellectual hyperactivity in order to satisfy the passionate desire. However, in adolescence there is a reverse picture, since previous interests in specific real things are unexpectedly replaced by the tendency to abstract judgment which usually does not coincide with behaviour and actions. According to A. Freud, the propensity for such profound thinking in the period of puberty is explained by the "specific reaction of teenagers for the need to choose between sexual attraction and its rejection, and the process of intellectualization is one of the ways to solve this problem" ${ }^{20}$.

As we see, in Zweig's "Letter from an Unknown Woman" "giving money to the beggar by the beloved" was captured in the memory of a young girl as a symbolic act reflecting, first of all, her dependence on the game of her own hidden mysterious forces of the Oedipus complex. In other words, she unknowingly identified herself with a similar situation of the poor beggar who, in the imagination of the child, wished that he would be given not penny-worth compassion, but a spiritual wealth of heart warmth.

What do white roses, the blue vase, the death of an unknown son, the beggar, who are in a hurry to give alms, symbolise? All these are the treasures of the sacrificial unanswered love which passes invisibly past the whole life of the heroine.

These aesthetically sophisticated writings - "The Letter from an Unknown Woman" by S. Zweig and "Jay's wing” by I. Franko - reach the most intimate archetypal depths of the human soul, perhaps even veiled by

${ }^{19}$ Цвейг С. Письмо незнакомки. Новеллы. Минск: Выш. шк., 1987. С. 147-148.

${ }^{20}$ See: Фрейд А. Психология «я» и защитные механизмы. Москва: Педагогика, 1993. $144 \mathrm{c}$. 
the alter ego of the authors themselves. Their narrative high-artistic strategy in "two letters" from "two strangers" outlines the invisible, trouble-free duel of true love with stale indifference, violent emotions with cold intelligence. Indeed, both Franko and Zweig give an opportunity to understand that love is not only a mutual relationship with a particular person or a means of overcoming alienation, but a source of revelation, newly gained conscience, ultimately spiritual health, a mature setting, an orientation of a person's character which determines his/her attitude towards the world as a whole.

\section{Ivan Franko and Sigmund Freud: Texts and Contexts}

Franko's "From the secrets of poetic creativity" as a creative code of Ukrainian literary and psychoanalytic thought is largely consonant with one history of Freud's academic life. In 1906, on the occasion of the fiftieth anniversary, the students presented their teacher S. Freud with a medallion, on one side of which there was depicted a profile of the jubilant, and on the other side, there was Oedipus who was solving Sphinx's riddle. The depicted scene was provided with the carved lines from the tragedy of Sophocles, "Oedipus the King", with deep meaning: "Both the solver of mysteries and the mighty king". Eyewitnesses retorted: when the jubilant read these words, he was very excited. As it turned out, since his student days, Freud dreamt of seeing his pedestal with the inscription of those lines by Sophocle in the gallery of monuments of famous scientists at the University of Vienna. The presented medallion had a subtext that symbolically embodied the great achievement of the founder of classical psychoanalysis who, just like Oedipus, managed to guess the riddle of the Sphinx.

Outside the mythological expression of ancient Greek stories, it concerns the justification of the unconscious processes outlined in the monograph "The Interpretation of Dreams" by S. Freud. According to the founder of classical psychoanalysis, dreams are formed as the result of two basic mental processes: the first one localizes unconscious instinctive desires, dreams, fantasies, and the other one performs the function of censorship which does not allow the unconscious desires to penetrate the 
sphere of consciousness in view of the moral aspect. However, during sleeping, the censorship weakens and even displaced unconscious desires can show themselves on the surface of consciousness in the form of metamorphosis, images-symbols, metaphors, etc. Thus, according to S. Freud, the analyst has an opportunity to decode true hidden meaning of dreams and, using the "therapeutic way", to bring it to the patient who must have an insight that ultimately leads to the disappearance of neurotic symptoms.

Actually, the theory of the Austrian psychotherapist in modern psychoanalysis has become the main axis of rotation regarding the new understanding of a human's psychological problems of. It is difficult to say whether Ivan Franko wanted to see his monument near the University of Lviv, as well as S. Freud wanted to see his near the University of Vienna, but in 1895, he made an attempt to take up a post at the Department of Ukrainian Literature. However, his candidacy was not approved. A similar fate also occurred with Franko's reception of the scientific (innovative in the psychoanalytic aspect) treatise "From the secrets of poetic creativity" (1898), published two years earlier than the work of S. Freud "The Interpretation of Dreams" (1900), forestalling his theory. The interesting fact is that the parents of the founder of classical psychoanalysis, Jacob and Amalia (Natanson) Freud, who had a significant influence on the intellectual and psychological development of his son, came from Halychyna in Ukraine (Tysmynytsia and Brody).

The then criticism of "Literaturno-naukovyi vistnyk", "Kievskaia starina", "Urguelle. Eine Monatsschrift für Volkskunde", "Kurjer Lwowski" and other periodicals did not interpret properly the new ideas of Franko. In this regard, the ironic words of one classic-aphorist sound topical: "He was fluent in keeping silent in four foreign languages!" What is the reason for this "silence"? Why did Ukrainian literary and psychoanalytic thought turn out to be in the "alien in ours" state? This unbalanced scientific range can only be explained by a narcissistic-oriented setting. As H. Klochek rightly pointed out, "literary studies, especially in 
its methodological part",21, often "because of an egotistic need, builds itself only from its own material" ${ }^{22}$. This leads to anxiety and intolerance to the ideas of a new trend. Unlike the Freudian topical model of the mental apparatus (the system of the unconscious, the subconscious, and the conscious) containing three basic dimensions of the human psyche, I. Franko was conceptually guided by the Dessoire-like dualistic understanding of the concept of the "double ego" of the person, that is, "lower" and "upper" consciousness. In the end, S. Freud introduced the term "subconscious" only for the better understanding of dynamics between the unconscious and conscious internal processes of the person. In this regard V. Leibin rightly remarked: "The founder of psychoanalysis believed that reasoning about the subconscious, or misty obscure consciousness, is more obvious absurdity than the recognition of the hypothesis of the existence of the unconscious mental" ${ }^{, 2}$. Reflecting on the role of the unconscious in poetic creativity, in his scientific treatise, Franko gives many views from the literatures of ancient peoples (including the ancient Indian books of "Rigveda", ancient Persian "Zend Avesta", ancient Greek mythology, writings by Homer, Aeschylus, Plato, Democritus, Aristotle, etc.) in relation to the corresponding phenomenon. Thus, he called for the testimony of A. Mickiewicz that he created the poem "Pan Tadeusz" (1834) not by his own intelligence or imagination, but "received from God on the wings of inspiration" 24 . Some considerations correspond to the interesting fact of the last tragic years of I. Franko's life. R. Horak writes: "It is surely known that on December 13, 1913, sick Franko came to the Metropolitan's chambers (of Andrei Sheptytskyi - A. P.), he walked from his native house in Sofiyivka, in snowstorm, in order to congratulate Metropolitan with his birthday and gave him the first copy of the book "Wielka utrata" which, as he believed, was written by A. Mickiewicz. In this book, struggling with pain, he wrote the dedication to the

${ }^{21}$ Клочек Г. Трактат Івана Франка “Із секретів поетичної творчості” як предтеча української рецептивної поетики. Слово $і$ Час. 2007. № 4. С. 41.

${ }^{22}$ Ibid.

23 Лейбин В. Словарь-справочник по психоанализу. Санкт-Петербург: Питер, 2001. C. 412.

${ }^{24}$ Франко І. Із секретів поетичної творчості. Зібрання творів: У 50 т. [ред. колег.: М. Бернштейн та ін.]. Київ: Наукова думка, 1981. Т. 31. С. 58. 
Metropolitan with his own left hand. It was a miracle: after this incident, I. Franko could write with his left hand..." According to the author of the treatise "From the secrets of poetic creativity", T. Shevchenko's "Kobzar" proves that artistic creativity is different from the ordinary human ego. After all, the poet "often turns to his "thoughts" as to some creatures, separate from him, gifted by their own will" 26 , and also exalts the Muse "as his mother and teacher" 27 in the eponymous poem. Later, in the psychology of creativity, I. Franko demonstrated the universal law of poetic gradation based on Shevchenko's works, the essence of that law is to comprehend the extraordinary aesthetic and semantic effect by the means of natural selection of metaphors, ideas and images of our imagination (from one part to the whole and vice versa). Based on the generally accepted laws of associations in the contemporary psychology of W. Wundt and G. Steintal, I. Franko raised the problem of "a special poetic association of ideas". The scientific basis for this problem has become the future analyticalpsychological concept of artistic cognition of the psychology of creativity, mediated by K.-G. Jung, E. Neumann, D. Uznadze, L. Vygotsky and others. I. Franko's "From the secrets of poetic creativity" coincides with Freud's theory of the topical (the unconscious, the subconscious, and the conscious), structural (Id, Ego, Super-Ego), dynamic models of the mental apparatus $^{28}$. If the topical and dynamic models of the human psyche in the interpretation by I. Franko are expressed by the terminology of M. Dessoire, the structural one is most connected with the anthropological and emotional observation of the writer. Thus, the psychological authority "Ego" (according to S. Freud) has Franko's correspondence to "memory" and "will" which direct "our physical or spiritual forces into one direction"29; "Super-Ego" is considered to be the special consciousness,

${ }^{25}$ Горак Р. Львів - місто Івана Франка. Львів: Центр Європи, 2010. С. 13.

${ }^{26}$ Франко І. Із секретів поетичної творчості. Зібрання творів: У 50 т. [ред. колег.: М. Бернштейн та ін.]. Київ: Наукова думка, 1981. Т. 31. С. 58.

${ }^{27}$ Ibid.

28 Seе: Холдер А. Фрейдовская теория психического аппарата. Энциклопедия глубинной психологии: В 4 m. Т. 1. Москва : ЗАО МГ Менеджмент, 1998. С. 226-265.

${ }^{29}$ Франко І. Із секретів поетичної творчості. Зібрання творів: У 50 т. [ред. колег.: М. Бернштейн та ін.]. Київ: Наукова думка, 1981. Т. 31. С. 78. 
"something separate from our inner "self" 30 ; "It" is a sensation that manifests the instinctive needs of the individual. Unlike S. Freud, I. Franko did not identify the writer's poetic activity as the sublimation of satisfying sexual desires or escaping from the neurotic perception of reality.

However, S. Freud (see: "Interpretation of dreams") and I. Franko (see: "From the secrets of poetic creativity") believed that in every human behaviour as a stimulating factor there is a need for mental adaptation through constant disturbance of mental equilibrium. For this reason, they focus not on adapting the individual to the outside world, but on his inner "equilibrium" of all mental institutions. After all, the processes of mental adaptation lead to changes in certain established emotional structures that are connected with conflict and protection.

In "From the secrets of poetic creativity", I. Franko paid a lot of attention to unconscious processes in the consideration and interpretation of normal and anomalous phenomena, as well as the driving forces of instincts, desires, ideas about emotional conflict for which the mental apparatus must find solutions to overcome heterogeneous fears and to establish an acceptable level of internal equilibrium.

In Franko's "From the secrets of poetic creativity" and in Freud's "The Interpretation of Dreams", we can trace a common view that, according to the picture of human mental problems, superseded traumatic experiences can be masked, the awareness of which (through the method of free associations) leads to insight. In early childhood, the mental device is not structured enough and becomes multi-faceted only in the course of its development. This generates the actualized approach to the differentiation of mental structures, one of which, according to both scientists, performs protective functions. With the advent of the conscious "Ego", the ability of mental processes develops to "split off" the affectively charged memories, fantasies, representations which enter into contradiction with it and are displaced into the sphere of the unconscious.

I. Franko, unlike S. Freud, was close to the analytical psychology of K.-G. Jung who considered the phenomenon of human creativity as a collective unconscious. "The greatest part of all those suggestions which

${ }^{30}$ Ibid. 
we call upbringing and in which the man absorbs the achievements of many-thousand-year cultural work of the whole human race, passing through a clear layer of upper consciousness, gradually darkens, disappears from the surface, that is, it has a burial place in the deep well of the soul just like gold in underground veins" 31 , - this is the way how the writer interpreted the psychic phenomena of the individual, which, in analytical psychology, is called the "Self", in his scientific treatise. So like K.-G. Jung, I. Franko insists that unconscious mental covers not only infantile anxiety, negative forces during the artist's mental illness, but also has positive meaning for him because the thoughts arising because of the illness, independently from the author, can become truly valuable. Franko considered separating the poetic feature of man as a "separate psychic type" of the individual to be necessary in psychology. Since "what is important for science is the cognition of the main mark: the eruptiveness of his lower consciousness, i.e. his/her ability from time to time to lift the whole complexes of long-buried impressions and memories, combined, usually unconsciously, with one another in the daylight of the upper consciousness", claimed the writer ${ }^{32}$. The treatise "From the secrets of poetic creativity" traces two types of creative activity of a person: one is characterized by "cold, mental, conscious assembly" and the other one is "the resorptive force of the lower consciousness". Consequently, I. Franko, considering the poetic fantasy of a dream to be a special kind of hallucinations and affections, remarks that every person in ecstasy or in dreaming is an artist to some extent. In the terms of K.-G. Jung, it is a psychological and visionary type of artistic creativity and an extrovert and introvert author's position.

Franko's analytical and psychological interpretation of the "dream" and "poetic" fantasies as a "unifying symbol" of the spiritual treasures of ancestors in the creative process of the individual reveals the archetypal understanding of the "collective unconscious". This discovery led to significant achievements in modern psychology. Having considered the synthetic nature of methodological systems in Ukrainian literary criticism,

${ }^{31}$ Франко І. Із секретів поетичної творчості. Зібрання творів: У 50 т. [ред. колег.: М. Бернштейн та ін.]. Київ: Наукова думка, 1981. Т. 31. С. 62.

${ }^{32}$ Ibid. P. 64. 
in particular psychoanalytic one, H. Klochek came to the conclusion that "From the secrets of poetic creativity" by I. Franko is "the classics of receptive poetics"33. He pointed out that developments by I. Franko were almost not studied in Ukrainian literary criticism that is explained by the entropy of literature and the anarchism of the very literary criticism, including the methodology because it did not account for other developments in this area, so the same concept was differently named in different methodological directions. Receptively interpreting the text, the author raised the psychological problem of anarchism, egocentrism and narcissism in the methodology of literary criticism. This allows to understand the atheistic reasoning of post-modernist theories in general, literary works of which, according to N.Zborovska, play the meaning, replace real communication by simulation.

This approach deconstructs any logocentric methodology; instead it proposes "over-interpretation" which implies "infinite plurality of meaning separation" in theories of U. Eco, C. Brooke-Rose, R. Rorty, J. Culler, and others. In "From the secrets of poetic creativity", I. Franko draws attention to the fact that most aesthetic categories in art are related to the senses of sight, hearing, sensation, etc. He outlines the psycho-linguistic problems and perspectives of analytical interpretation of texts in Ukrainian literature, notes that visual images are above the auditory and touching ones, and the least ones are taste and olfactory. Consequently, the methodological approach to the study of the artist's work is the coexistence of the elements of literature studies and psychoanalysis. I. Franko points out the problem of syncretism, because he believed that literary criticism should be aesthetic, should integrate into modern psychology, to use its methodological apparatus. Unfortunately, psychoanalytic literary interpretation within the limits of the spiritual Christian outlook that was initiated in Ukrainian and Western European literary studies by I. Franko, was not continued.

Thus, the psychoanalytic discourse of the first decades of the twentieth century was marked by the works of M. Wulff "Critical Review

${ }^{33}$ Клочек Г. Трактат Івана Франка “Із секретів поетичної творчості” як предтеча української рецептивної поетики. Слово $і$ Час. 2007. № 4. С. 40. 
of the 1909 German Psychotherapeutic Literature", "Psychology of Children's Whims" (1929), O. Heimanovych, Director of the Ukrainian Research Institute, "On the psychoanalytic method of treatment of neuroses (by Freud)" (1910), V. Likhnytskyi "Psychotherapy and Psychoanalysis" (1912), I. Birshtein "The Dream of Harshyn" (1913), E. Bergler "Psychoanalysis. The essence and significance of the professor's teachings of S. Freud" (1923), Ya. Kohan "Identification and its role in artistic creativity" (1926), "On some parallels of libido development in phylogeny and ontogenesis" (1927), I. Apner "Sexual neuroses and their therapy" (1926), V. Pidmohylnyi "Ivan LevytskyiNechui (Attempt of psychoanalysis of creativity)" (1927), V. Hakkebush "The History of Psychoanalysis in Ukraine", Ye. Perlin "Again, about Freudism and Art" (1927) and others. Most of them used in their writings a psychobiographic method as an analysis of the Oedipus complex, the situation and the analysant's conflict.

N. Zborovska rightly noted that "psychoanalytic theory, which was formed in accordance with the spirit of time, was not only a component of modernist culture, but also a tool for its interpretation",34. This is because Western European literary studies initiated intellectual atheistic discourse, mediated by feminist, poststructuralist, postmodernist tendencies of J. Derrida, R. Barthes, J. Kristeva, H. Cixous, L. Irigaray, C. Clément and others. Adhering to the tendency of synthesis of various sciences, they subordinated psychoanalytic consciousness to deconstructivist practice. The Ukrainian opponent of postmodernism, S. Kvit correctly warned about the negative influence of assimilation into "someone else's rhetoric", since then, along with positive qualities, one will have to absorb the negative ones. This also applies to Nietzsche's "philosophy of life" which influenced the European thought of the twentieth century by joining the general cultural discourse of modernism. I. Franko also noticed that these influences were mostly not ideological, but instead they had an aesthetic shade of "cheap fashion". Naming F. Nietzsche as "a poet-swindler" with absurd dithyrambs about the "superman", he concluded that "Nietzsche

34 Зборовська Н. Психоаналіз і літературознавство: навч. посіб. Київ: Академвидав, 2003. С. 103. 
and Nietzscheans... consider each other superior to all laws, beyond all social development, crave everything for themselves from the society and give nothing instead" 35 .

In his treatise "From the secrets of poetic creativity", I. Franko interpreted the laws of association of ideas, the concept of the unconscious mental, poetic and dream fantasies of the person as his/her spiritual factors, and not as psychic reflections as S. Freud did in his "Interpretation of Dreams". For the writer, the meaning of art as one of the forms of social consciousness and a kind of activity is to bring benefits for the true nature of the individual. Here appears the thesis: the reception of the reader is subjected to the "law of double expression of feelings" (M. Mamardashvili) which is conditioned by objective reality and illusory and artistic fiction. However, the experiences of the reader, real and emotional, are "spiritual reality" which is reflected in the textual images of his/her imagination. This analysis of the aesthetic response for I. Franko is similar to Th. Lipps "theory of feelings" (the recipient introduces his/her emotions into the object of literature) and B. Christiansen's "theory of reflection of life reality" (literature affects the recipient's emotions). In his treatise, I. Franko rightly states that in the metaphysical world of fiction, there are processes of manipulation. Since the reader empathizes with the narrator, he/she is concerned with the narrator's spiritual system of values. Consequently, any image is associated with empirical images in the mind of the recipient which constitute the reflected paradigm of what has been seen.

According to I. Franko, the analytical task of the artist is to reintegrate the subject of his own history, which is "past" to the extent that the past has been historicalized in the present. An individual is constantly experiencing a state characterized by a contradiction in body and spirit. This interpretation of the unconscious mental of the person in the treatise "From the secrets of poetic creativity" gives a lot of explanations to the psychoanalytic problems faced by Freud's theory of free associations in the paradigm of the topical and structural models of the mental apparatus. This

35 Франко І. Юрій Брандес. Іван Франко Зібрання творів: У 50 т. [ред. колег.: М. Бернштейн та ін.]. Київ: Наукова думка, 1981. Т. 31. С. 382. 
drives to the pessimistic unjustified conclusions of the founder of the classical psychoanalysis: "Dynamically moving in all directions, a complex of human nature can be extremely rarely subject to a simple alternative, as our morality would like it to be" ${ }^{36}$. Unfortunately, the innovative psychoanalytic concept of I. Franko's "From the secrets of poetic creativity" (1898) was not properly appreciated by the then criticism, and it remains to be a kind of palimpsest of the monograph "The Interpretation of Dreams" (1900) by S. Freud.

\section{CONCLUSIONS}

Analyzing the psychoanalytic horizons of Ukrainian-Austrian literary interactions in writings by I. Franko, S. Zweig and S. Freud, we focused on the dynamics of its two main dimensions: artistic and scientific.

The comparative analysis of the stories "Jay's Wing” by I. Franko and "The Letter from an Unknown Woman" by S. Zweig became a kind of "physiology" of the leitmotif of love which, as an artistic text, was transposed into the psychoanalytic sphere of perception. Besides, $\mathrm{S}$. Freud confirms that fiction is the carrier of psychological knowledge about a person.

The shifting of the ideas and concepts of the psychoanalytic paradigm to the metaphysics of artistic text happans due to the fact that, in the structured system of poetics, there is a diagnostic and therapeutic selfdetermination of the narrator, protagonist, prototype, author, etc. In this way, the artistic model of thinking is ahead of the psychoanalytic one. This proves the psychologism of Ukrainian and Austrian classical literature, in particular the stories "Jay's Wing" by I. Franko and "The Letter from an Unknown Woman" by S. Zweig, in which the typology of love concepts by S. Freud, E. Fromm and K. Horni is traced.

The affinity of psychoanalysis and fiction lies in revealing and exploring the deep, inner world of a person. However, the purpose of psychoanalysis contains interpretative and therapeutic effects; and literature, aesthetic one. Paradigmatic relations between these spheres of

${ }^{36}$ Фрейд 3. Толкование сновидений [под. ред. Б. Г. Херсонского]. Київ: Здоров’я, 1991. C. 323. 
activity are in the process of establishing. The bright confirmation of certain considerations is I. Franko's "From the Secrets of Poetic Creativity" and S. Freud's "Interpretation of Dreams" in which the phenomena of dreams and poetic imagination were seen as the "royal road" to an unconscious mentality of an individual. I. Franko's treatise "From the Secrets of Poetic Creativity" is the forerunner of psychoanalytic literary criticism in general. Franko's work coincides with Freud's theory of topical (the unconscious, the subconscious, the conscious), structural (It, Ego, Super-Ego), dynamic models of the mental apparatus of a person. If the topical and dynamic models of the human psyche, in the interpretation of the Ukrainian thinker, are expressed in terms of the terminology of M. Dessoire, the structural one is more connected with the anthropological and emotional observations of the writer.

S. Freud appreciated the collaboration of analysts and artists; he believed that creative personalities collect artistic material from the inner spiritual sources of a person which remain a mystery to science. This prompted him to the in-depth study of masterpieces of world culture and the creation of vivid illustrations of the clinical findings obtained in the process of therapeutic practice. Thus, the psychoanalytic code of I. Franko's creativity in the context of Austrian literary interactions makes it possible to comprehend the internal problems of the innermost moves of the human soul.

\section{SUMMARY}

The paper is devoted to the works of Ivan Franko in the context of Ukrainian-Austrian literary interactions that are considered from the point of view of psychoanalysis. The stories "Jay's Wing” by Ivan Franko and "Letter from an Unknown Woman" by Stefan Zweig are analyzed through the prism of the anthropology of love. Existential problems of a human in the aspect of humanistic psychology (neofreudism) by Erich Fromm are raised by using the factual material. Symbolic parallels in fiction make it possible to understand that the Ukrainian writer portrays the love of vision and passion which seeks for reciprocity, while the Austrian writer portrays invisible and sacrificial love which seeks for perfection. This supports the 
use of Fromm's concept of love with two different worldview attitudes to life: "-to have-" and "-to be-". "From the secrets of poetic creativity" by Ivan Franko and "The interpretation of dreams" by Sigmund Freud are also researched through the prism of psychological analytical measurements. Analogies, differences, interpretations of research by Ukrainian and Austrian scholars open up a systematic approach to understanding the phenomenon of the unconscious, in particular, in the psychology of creativity.

\section{REFERENCES}

1. Горак Р. Львів - місто Івана Франка. Львів: Центр Європи, 2010. 288 c.

2. Денисюк I. Ровиток української малої прози XIX - поч. XX ст. Львів: Науково-видавниче товариство “Академічний Експрес”, 1999. $280 \mathrm{c}$.

3. Сфремов С. Іван Франко: Критично-біографічний нарис. 2-ге вид. 3 дод. Київ: Слово, 1926. 256 с.

4. Зборовська Н. Психоаналіз і літературознавство: навч. посіб. Київ: Академвидав, 2003. 392 с. (Серія: “Альма-матер”).

5. Клочек Г. Трактат Івана Франка “Із секретів поетичної творчості” як предтеча української рецептивної поетики. Слово $і$ Час. 2007. № 4. С. 39-45.

6. Лейбин В. Словарь-справочник по психоанализу. Санкт-Петербург: Питер, 2001. 688 с. (Серия: “Золотой фонд психотерапии").

7. Лихтенштейн И. Жизнь и смерть Стефана Цвейга глазами врача. Новости медицинь и фармачии в мире: проф. спец. изд. для врачей. 2012. № 19, 20-22.

8. Маланюк С. Книга спостережень: В 2 т. Торонто: Гомін України, 1962. Т. 1. 525 с.

9. Мельник Я. І остатня часть дороги... Іван Франко: 1908-1916. Дрогобич: Коло, 2006. 439 с.

10. Мень А. История религии: В 7 т. Москва: Изд-во СоветскоБританского совместного предприятия Слово, 1991-1992. 
11. Мочульський М. Одно видіння Івана Франка. Студії та спогади. Львів: “Ізмарагд”, 1938. С. 175-190.

12. Печарський A. Психоаналітичний аспект української белетристики першої третини XX сторіччя: монографія. Львів: ЛНУ імені Івана Франка, 2011. 466 с.

13. Тихолоз Б. Психодрама Івана Франка в дзеркалі рефлексійної поезії: Студії. Львів: ЛНУ ім. І. Франка, 2005. 180 с. (“Франкознавча серія"; Вип. 7).

14. Франкл В. Человек в поисках смысла: Сборник. Москва: Прогресс, 1990. 386 с. (Серия: “Б-ка зарубежной психологии”).

15. Франко I. Із секретів поетичної творчості. Зібрання творів: У 50 т. [ред. колег.: М. Бернштейн та ін.]. Київ: Наукова думка, 1981. T. 31. C. $45-119$.

16. Франко I. Сойчине крило. Твори: У 50 т. Київ: Наук. думка, 1979. Т. 22. С. 53-93.

17. Франко І. Юрій Брандес. Зібрання творів: У 50 т. [ред. колег.: М. Бернштейн та ін.]. Київ: Наукова думка, 1981. Т. 31. С. 378-384.

18. Фрейд А. Психология “я” и защитные механизмы. Москва: Педагогика, 1993. 144 с.

19. Фрейд 3. Толкование сновидений [под. ред. Б. Г. Херсонского]. Київ: Здоров'я, 1991. 384 с.

20. Фромм Э. Душа человека. Москва: Республика, 1992. 430 с. (Серия: “Мыслители ХХ века").

21. Фромм Э. Иметь или быть? Москва: Прогресс, 1986. 240 с.

22. Холдер А. Фрейдовская теория психического аппарата. Энщиклопедия глубинной психологии: B 4 m. [под общ. ред. А. М. Боковикова]. Т. 1. Москва: ЗАО МГ Менеджмент, 1998. C. 226-265.

23. Цвейг С. Казанова; Фридрих Ницше; Зигмунд Фрейд. Москва: Интерпракс, 1990. 256 с.

24. Цвейг С. Письмо незнакомки. Новеллы. Минск: Выш. шк., 1987. 336 с. (Серия: “Б-ка отеч. и зарубеж. классики”).

25. Haenel Th. Psychologe aus Leidenschaft. Stefan Zweig - Leben und Werk aus der Sicht eines Psychiaters. Droste, Düsseldorf 1995. 
26. Lunzer H. Renner G. Stefan Zweig 1881-1981. Aufsätze und Dokumente. Zirkular. Sondernummer 2 (Oktober 1981). Herausgegeben von der Dokumentationsstelle für neuere österreichische Literatur in Zusammenarbeit mit dem Salzburger Literaturarchiv, Wien 1981.

27. Matuschek $O$. Drei Leben. Stefan Zweig - Eine Biographie. S. Fischer, Frankfurt, 2006.

28. Weinzierl Ul. Stefan Zweig, Triumph und Tragik. Aufsätze, Tagebuchnotizen, Briefe S. Fischer, Frankfurt 1992.

\section{Information about the author:} Pecharskyi A. Ya.,

Doctor of Philology (Habil.), Professor, Mykhailo Vozniak Ukrainian Literature Department, Ivan Franko National University in Lviv 1, Universytetska str., Lviv, 79000, Ukraine

\section{Zymomrya I. M.,}

Doctor of Philology, Associate Professor, Head of the Department of Translation Theory and Practice, Uzhgorod National University 14, Universytets'ka str, Uzhhorod, 88000, Ukraine 


\section{COGNITIVE AND PSYCHOLINGUISTIC NATURE OF METAPHOR AS A BASIS OF AUTHOR'S CONCEPTUAL SYSTEM IN POETRY}

\section{Chendey N. V.}

\section{INTRODUCTION}

In modern linguistics the conceptual methodology and procedures of poetic language study are elaborated by a separate branch of poetics cognitive, whose scientific vector is aimed at the analysis of artistic semantics with a special emphasis on linguistic and cognitive strategies of forming and processing information, which is actualized in poetic texts ${ }^{1}$. The principle of embodied understanding proves to be fundamental and it bases the analogy mapping as a mechanism of conceptual metaphor and metonymy formation ${ }^{2}$. Thus, in the theory of cognitive poetics a special focus is put on a problem of language metaphorization that involves not only the stylistic tropes, but embraces the whole process of nomination and sense organization in poetry, defining the peculiarities of the conceptual system of its author.

The study of conceptual metaphors in literary texts enables to reveal not only the specificity of verbal poetic images formation, but the explication of a conceptual content of a literary text and on this basis further define the principles of author's cognitive style ${ }^{3}$. The analysis of recent research on poetry confirms that cognitive poetics studies different stages of an artistic text functioning cycle: the author (an individual

1 Воробйова О. П. Когнітивна поетика : здобутки i перспективи / О. П. Воробйова // Вісник ХНУ ім. В.Н.ККаразіна. Ювілейний збірник "200-річчя Харківської мовознавчої школи”. Харків : Константа, 2004. № 635. С. 18-22.

${ }^{2}$ Freeman M. Poetry and the Scope of Metaphor : Toward a Cognitive Theory of Literature / M. Freeman // Metaphor and Metonymy at the Crossroad: A Cognitive Perspective / Ed. Barcelona A. Berlin ; N.Y. : Mouton de Gruyter, 2000. P. 253.

${ }^{3}$ Freeman M. The Body in the World: A Cognitive Approach to the Shape of a Poetic Text / M. Freeman // Cognitive Stylistics : Language and Cognition in Text Analysis / Ed. by E. Semino, J.V. Culpeper. Amsterdam ; Philadelphia : John Benjamin's Publishing House, 2002. P. 24. 
concept sphere) - the artistic reality (a conceptual text structure) - the reader (cognitive mechanisms of perception) as well as the interconnection between all of them. In particular, R. Tsur, one of the proponents of cognitive poetics, considers its primary tasks to be the study of cognitive mechanisms of perception and systematization of psychological affects, provoked by poetry and tightly connected with the specificity of text organization ${ }^{4}$. The issue of individual conceptual sphere as a mental basis of the author's poetic style remains open due to the complexity of its structure and compulsory components typology. In this research the attempt has been made to model an individual conceptual system of the author by studying poetic metaphors, their cognitive and psychological nature in order to define the features of the poet's individual style.

\section{Cognitive and psycholinguistic aspects of metaphor}

Metaphorization is one of the distinguishing features of the artistic perception of reality. These are metaphors in a poetic text that make it possible to transform animate and inanimate phenomena into abstract allegories. Being personified in metaphors they turn into spiritual creatures, making poetry alive. Moreover, a metaphor can be easily interwoven in dense canvas of a poetic text, designing the structure of complex verbal poetic images that successfully combine abstract and subject-concrete, preserving their inner symbolic content. And it is romantic poetry that proves to be the source of concentration "the secrets of soul", , and its language is a code, deciphering which a reader penetrates into an emotional world of a poetic hero, touching upon his/her mysterious passions and multiple associations.

Cognitive linguistics gives metaphor a key position in structuring and understanding reality, reflecting cultural traditions of selecting modes of abstract concepts verbalization, conditioned by various extralinguistic factors (background knowledge about the world) typical of a given

\footnotetext{
${ }^{4}$ Tsur R. Toward a Theory of Cognitive Poetics / R. Tsur. Amsterdam: Elsevier Science Publishers, 1992. P. 14.

5 Павличко С.Д. Байрон. Нарис життя i творчості / Соломія Дмитрівна Павличко // Зарубіжна література : Дослідження та критичні статті. К. : Вид-во Соломії Павличко “Основи”, 2001. С. 153.
} 
language community ${ }^{6}$. One of the theoretical postulates of cognitive studies is an assumption that metaphor is a principle of thinking that provokes a semantic process of "subjecting" non-subject entities (psychological, mental, emotional) and their conceptualization by analogy with the subject world ${ }^{7}$. Correspondingly, the key function of metaphor seems to be its capacity to give an access to understanding abstract spheres of human experience. In G. Lakoff's opinion, a language system itself enables the conceptualization of invisible worlds, which become similar to visible ones for their verbalization and comprehension. A metaphor provides an understanding of experience and allows the perception of its distant fragments that lack their own pre-conceptual structure. G. Lakoff calls the ability to think metaphorically "a real triumph of human mind". The scholar considers metaphor to be a main tool of thinking, as far as any attempt to describe it should contain mechanisms of imagination and the latter is inseparable from metaphorical thinking. Metaphor is inbuilt in a human notional system and guides the human activities in the process of perceiving the reality since metaphor contains knowledge about the world.

A blended psychological and linguistic study of metaphor displays two planes of this complex phenomenon: 1) a content plane which reveals the psychological processes of reality elaboration; and 2) an expression plane that demonstrates a linguistic relation between the components serving in language as the evidence of these psychological processes.

Apprehension and perception have always been tightly linked in classic theories of metaphor. In P. Ricoeur's opinion, both of them are natural components of the process described in the metaphor theory as "an interaction" and represented in a semantic plane of metaphor". Being accompanied and extended by apprehension, perception is called a

${ }^{6}$ Арутюнова Н. Д. Метафора и дискурс / Н. Д. Арутюнова ; [пер. с анг., фр., нем., исп., польск. яз., общ. ред. Н. Д. Арутюновой и М. А. Журинской] // Теория метафоры : сборник. М. : Прогресс, 1990. С. 5.

${ }^{7}$ Lacoff G., Johnson M. Metaphors We Live By / G. Lacoff, M. Johnson. Chicago : The University of Chicago Press, 1980. P. 75.

${ }^{8}$ Lacoff G., Johnson M. Metaphors We Live By / G. Lacoff, M. Johnson. Chicago : The University of Chicago Press, 1980. P. 82.

${ }^{9}$ Рикёр П. Метафорический процесс как познание, воображение и ощущение / П. Рикер ; [пер. с анг., фр., нем., исп., польск. яз., общ. ред. Н. Д. Арутюновой и М. А. Журинской] // Теория метафоры : сборник. М. : Прогресс, 1990. С. 429. 
"mood". Thus, any poem structures a mood which emerges in the result of chaining a range of words. A mood is a means by which a poem has an impact on us, being an iconic sign. In the line with this, the philosopher states that "the unity of poetic language is the unity of mood" and metaphoric images express or interpret this mood, which is "a poetic language and nothing beyond it", "mood is iconic as it is felt",

Being an inseparable component of apprehension, a metaphoric sense is revealed in a verbal structure of poetic language. The psycholinguistic approach to a metaphor study puts to the fore its sensual aspect that is brilliantly displayed in poetry. It creates a breeding ground for an amalgamation of sense and perception, a sensual world vision that distinguishes a poetic language from non-poetic, in which sense is totally purified from a sensual component.

A combination of sense and perception, concentration and selfsufficiency of poetic language, its capacity to design an imaginative world comprise the essence of iconic image. Thus, a key problem that appears in connection with the inclusion of the notion of image in the metaphor theory refers to the status of a sensual component, i.e. a non-verbal factor in a semantic theory.

The best explanation of iconic in the semantic theory of metaphor was given by M. Hester on the basis of the notion "to see as" that is realized in the process of reading and refers to a "mode of apprehension realization". In his opinion, "to see as" provides a real connection between a vehicle (a shell, an image) and a tenor (content, sense). Correspondingly, to interpret a metaphor means to set a range of meanings in which an image is taken as sense. "To see as" is an intuitive relation that combines an image and sense. A metaphor, which is based on the notion "to see as" defines a figurative function of poetic language, called by Hester "a picture of thinking"11.

In his turn a link between apprehension and perception Gaston Bachelard designated as "retentissement". In poetry a verbal meaning

${ }^{10}$ Рикёр П. Метафорический процесс как познание, воображение и ощущение / П. Рикер ; [пер. с анг., фр., нем., исп., польск. яз., общ. ред. Н. Д. Арутюновой и М. А. Журинской] // Теория метафоры : сборник. М. : Прогресс, 1990. С. 432.

${ }^{11}$ Hester M. B. An Analysis of the Meaning of Poetical Metaphor / M. B. Hester. L., 1964. P. 68. 
produces images that seem to be instaurated imprints of sensual experience. And if poetry is a fire, then images are brashwood that should be constantly supplied for imagination flight. Thus, "the unity of images melted by fire is stronger than the unity of ideas"12.

Early research of literary texts from the perspectives of cognitive linguistics proved the necessity of studying conceptual metaphoric systems as inseparable elements of author's individual style in poetry. The main focus is shifted to the idea that language of poetry relates to the spheres of conceptual metaphors functioning, as far as basic metaphoric concepts are integral parts of both common (universal) and individual (personal) conceptual domains.

The analysis of poetic texts enabled G. Lakoff and M. Turner to establish a set of basic metaphors, called specific-level metaphors, which function in poetry of different cultures and epochs. These metaphors structure the conceptual domains of such concepts as LIFE, DEATH and TIME. According to G. Lakoff and M. Turner, the specificity of poetic composition lies in the fact that basic metaphors undergo the process of the author's interpretation, resulting in the formation of novel metaphors. They distinguish three mechanisms of their creation: 1) various combinations on the basis of specific-level metaphors; 2) a metaphoric concept slots extension; 3) a different metaphoric concept slots filling ${ }^{13}$. O. P. Vorobyova considers these mechanisms to be extension, elaboration, combination and questioning. To illustrate them the scholar analyses V. Woolf's short story "The Mark on the Wall"14.

V. H. Nikonova designates novel metaphors as occasional metaphors and assumes them to be a conceptual basis of verbal poetic images, created by the author to model a conceptual space of a poem and produce an impact on a reader ${ }^{15}$. In her opinion, an image is one of the most important

${ }^{12}$ Башляр Г. Фрагменти Поетики Вогню / Густав Башляр ; [пер. 3 фр.]. Харків : Фоліо, 2004. С. 81.

${ }^{13}$ Lacoff G., Turner M. More than cool reason: a field guide to poetic metaphor / G. Lacoff, M. Turner. Chicago : University of Chicago Press, 1989. P. 52.

${ }^{14}$ Воробйова О. П. Когнітивна поетика : здобутки і перспективи / О. П. Воробйова // Вісник ХНУ ім. В. Н. Каразіна. Ювілейний збірник "200-річчя Харківської мовознавчої школи”. Харків : Константа, 2004. № 635.С. 18-22.

${ }^{15}$ Ніконова В. Г. Трагедійна картина світу в поетиці Шекспіра : монографія / Віра Григорівна Ніконова. Дніпропетровськ : Вид-во ДУЕП, 2007. С. 303. 
structures in the author's conceptual system that reveals how h/she perceives, categorizes and interprets the reality.

\section{Metaphor and the principles of modeling a conceptual system}

As a unique cognitive mechanism metaphor imposes its peculiarities on structuring (or modeling) the conceptual system of the author.

Metaphor offers a personal perspective on the object, predetermining the way and the method of thinking about it. Images that implement a certain concept reflect a sustainable model that determines the direction of the concept development and its place in the structure of the interaction with other concepts. This conceptual model forms a channel through which a thought flows. The construction of a conceptual system is possible through the identification and description of this model or models. Thus, a metaphor and a conceptual system form an indissoluble unity. On the one hand, the analysis of metaphor mechanisms inevitably requires consideration of its functioning in the conceptual system of the author. On the other hand, it is possible to study the organization of the system through the metaphorical expressions. This raises the question of the reader's understanding of metaphors, used by the author in the text. Obviously, a poetic metaphor always contains some inaccessible meaning, correlating with the personal experiences of an author. Besides, a reader can put his/her individual meanings that are inseparable from their feelings and associations. This parallel outcome of the meanings predetermines the mystery of metaphor, its partial or complete unpredictability. An act of metaphor perception presupposes such a complex and multidimensional response from the conceptual system of the reader that would fully cover it. Creating and understanding metaphor is equally designed for involvement of both participants of the dialogue - the writer and the reader. When the reader is confronted with already mastered concepts, his/her goal is to actualize them in mind. This is the case of the so-called trite or linguistic metaphor.

The process of forming a concept in the reader's mind becomes more complicated when it comes to a poetic metaphor. This complication does 
not depend on the specifics of the mechanisms of perception of such metaphors, but on the peculiarities of the author's world vision.

Teresa Dobzhinskaya, while describing metaphor as a poetic means of conceptualization, argues that "the study of a linguistic world vision, i.e. modeling function embodied in the language of metaphors, should create the basis for the analysis of individual worldviews, created in the literary texts" $"$. Thus, it becomes obvious that the peculiarity of metaphor as an object of study consists in the reflection of the dynamics of interaction between conceptual and linguistic spheres. The author's individual world vision (view, image) determines the choice of expressive means. It follows that metaphor is bilateral essence that synthesizes two areas - linguistic and mental - in a single generating mechanism. This is how a new concept is born in the reader's mind. The novelty lies not in questioning or replacement of an already existing concept, but in its clarification or interpretation through another one.

The theory of conceptual metaphor proves that metaphor plays an important role in the formation of a linguistic world vision. When trying to interpret the language world vision, images of a particular concept, contained in metaphor, "pass" through the language material, creating separate metaphorical fields and forming the background for a new mode of thinking, which is based on cognitive processes of conceptualization. The choice of a certain image in metaphor is associated with the subjective intention, which expresses human knowledge and experience. This intention gives a particular understanding of the world and the system of images, connected with the creator's conceptual world vision.

An interesting metaphorical understanding of the linguistic picture of the world is given by Danka Siroka: "The linguistic picture of the world, seen as mental awareness of words from a linguistic, cultural, social and psychological point of view, could be metaphorically described as a broad avenue with a number of small trees, and each of them is beneficial to the

16 Добжинская Т. Мой интимный маленький мир и поэтические способы концептуализации: Метафора / Т. Добжинская // Слово в тексте и в словаре. Сб. ст. к семидесятилетию акад. Ю.Д. Анресяна. Москва : Языки русской культуры, 2000. C. 536 . 
avenue, because it represents a new incentive for making the atmosphere of the avenue complete" 17 .

Most researchers conclude that the linguistic world vision is a part of conceptual and contains information that supplements the content of the latter. Thus, a linguistic world vision as an integral part of a conceptual world vision performs its two main functions - designates the basic elements of the conceptual world vision and explicates it with the help of language means. The conceptual world vision is broader than linguistic one, since its formation involves all of the psychiatric activities ranging from feelings, perceptions and ideas to thinking and self-awareness: a human feels the world, contemplates, learns and reflects it, using different types of reasoning.

The linguistic world vision represents, in fact, the same construct as scientific, philosophical and others, necessary for investigating the processes associated with the formation of the world visions in consciousness. It acts as an integral universal model capable of serving as a template for experience structuring. The conceptual world vision is constantly "redrawn", while in language the perception of the world imprints for a long time. Thus, the conceptual and linguistic world visions are closely connected. Language, on the one hand, objectifies the elements of the conceptual world vision, and on the other, directs the process of its formation.

The emotional sphere proves to be an important integral part of a conceptual system. The entire aspects of human psychological activity take part in its formation. The image of world emerges in various acts of experiencing the world as a whole. The human consciousness is not only the awareness of the object in the process of perception, but it is experienced as something emotionally coloured. In emotions an epistemological opposition between objective and subjective fades away, thus the subject and the object are experienced as a unity ${ }^{18}$.

${ }^{17}$ Siroka D. A Linguistic Picture of the World and Expression of Emotions through the Prism of Expressive Lexis / D. Siroka // Journal of Education Culture and Society. 2013. № 2. P. 304.

18 Постовалова В. И. Картина мира в жизнедеятельности человека / В. И. Постовалова. М. : Наука, 1988. С. 20. 
In psycholinguistics knowledge and emotions are interpreted as interconnected components of a human affective and cognitive orientation. The primitive level of consciousness is represented by feelings, which are structured and organized by emotion. A human reaction on a stimulus is based on sensory information. On the level of sensitive perception the image is understood as feeling. This is the first stage of a concept creation, a stimulus to its further development and fixation in a conceptual system through the word. And this is a starting point for other cognitive functions. Thus, emotion experienced as a feeling motivates thinking. Besides, emotion also appears as a response on a definite mental image. It follows that a cognitive process can initially provoke emotions. Here we deal with two dimensional connections in which an image plays a crucial role. An image activates emotion, which, in its turn, stimulates a cognitive process ${ }^{19}$.

On the stage of its formation a metaphor is an image. Metaphor appears as an image that appeals to emotions. Therefore an image has a special intermediate status between verbal and nonverbal aspects of metaphorical expressions.

M. V. Nikitin defines an image as "a mode by which consciousness solves the problems of conceptualization ${ }^{20}$. An image defines the human capacity to relatively unanimous means of differentiating classes of objects. An image ties the notion with a sensitively perceived object and along with this it transforms concrete feelings into general abstract thinking forms. Thus, an image is a nucleus component of a concept structure, without which a concept cannot function as a discrete unit of thought and interact with other concepts. Metaphor also represents an instance of a conceptual interaction. It is frequently used to designate a new concept or enrich an old one by drawing an analogy between new entities. An image can serve as an activator of consciousness information state when one concept can provoke or implicate another concept. This seems to be a metaphor's modeling potential.

${ }^{19}$ Фрумкина Р. М. Психолингвистика / Р. М. Фрумкина. Москва : Академия. 2001. C. 45

${ }^{20}$ Никитин М. В. Основы когнитивной семантики / М. В. Никитин. СПб. : Изд-во РГПУ им. А. И. Герцена, 2003. С. 76. 
A writer has different figurative images while touching upon language. They are tightly linked by his/her world vision. An analogy in metaphor is not a mere search for similarities in objects, events or phenomena, but it directly refers to the author's cognitive, creative aspiration and worldview.

The specificity of a metaphoric interaction in an author's conceptual system proves to be the so-called "magnet poles", i.e. a certain orientation marks that define a choice of a certain image in a metaphor. Their totality comprises a number of common schemas, shaping a cycle of associative links between different concepts. These concepts are believed to be core elements of the author's mental lexicon, which actualizes in a text and forms verbal networks, defined by the author's individual picture of the world.

A verbal poetic image is defined as a linguistic and cognitive construct that incorporates pre-conceptual, conceptual and verbal angles, being the crossing point of different types of knowledge ${ }^{21}$. In their turn, verbal poetic images based on comparison are interpreted as text constructs that contain conceptual and verbal poetic text levels.

\section{LIFE and DEATH metaphors as a core of the author's conceptual system in romantic poetry}

As it has been already mentioned, the analysis of poetic texts enabled G. Lakoff and M. Turner to establish a set of basic metaphors that structure the conceptual domains of such concepts as LIFE, DEATH and TIME, which can be found in poetry of different cultures and epochs ${ }^{22}$.

Let us illustrate G. Byron's metaphors of LIFE and DEATH in romantic poetry. A basic metaphor LIFE IS A ROAD has a negative emotive connotation in Byron's poetry, actualizing the meaning of life hardships and obstacles. For instance, in the poem "On My Thirty-Three Birthday" a basic metaphor is elaborated through the mechanism of

21 Бєлєхова Л. І. Словесний поетичний образ в історико-типологічній перспективі : Лінгвокогнітивний аспект (на матеріалі американської поезії) / Л. І. Бєлєхова. К. : Вид. центр КНЛУ, 2002. С.146.

${ }^{22}$ Lacoff G., Turner M. More than cool reason: a field guide to poetic metaphor / G. Lacoff, M. Turner. Chicago : University of Chicago Press, 1989. P. 4. 
degradation: "Though Life's dull road, so dim and dirty, I have dragged to three-and-thirty. What have these years left to me? Nothing - except thirtythree." Thus, a metaphor is realized in a nominative metaphoric expression and represents a case of attributive mapping, illustrating one of the most frequent landscape concepts in English metaphoric picture of the world. A metaphoric attributive construction "'Life's dull road, so dim and dirty" is adequately connected with a metaphoric predicate "I have dragged". In this way the poet implicitly expresses a specific meaning of the road that he has gone, vividly presenting it as rough and difficult. The use of such attributes as "dull", "dim" and "dirty" extends the basic metaphor, causing the reconstruction of poetic metaphors LIFE IS A DULL ROAD, LIFE IS A DIM ROAD, LIFE IS A DIRTY ROAD.

In the poem "Darkness" Byron metaphorizes WATER and its properties for creating a depressing picture of darkness and hollowness. On the background of water a feeling of disaster is depicted with a powerful poetic mood: "The rivers, lakes and oceans all stood still, And nothing stirred within their silent depths; Ships sailorless lay rotting on the sea, And their masts fell down piecemeal: as they dropped They slept on the abyss without a surge - The waves were dead;"

A basic concept LIFE IS WATER is implicitly understood through the meaning of "still" water that is deprived of dynamics and movement, which in turn is interpreted as death. Thus, the image of still water is a symbol of DEATH that is realized in a poem through a mechanism of extension the associatively connected images: "the rivers, lakes and oceans all stood still", "the waves were dead", and "nothing stirred within their silent depths", "Ships sailorless lay rotting on the sea", "they slept ...without a surge". Correspondingly, an emotive background of water that does not move has a vivid negative connotation which is revealed due to various meanings of lexemes still, silent, sailorless, rotting, without a surge. It becomes obvious that a poetically elaborated image of still water aims at realizing a binary metaphor of DEATH by degradation of conceptual content of a source concept.

A poetic metaphor LIFE IS AN OCEAN is reconstructed in the poem "The Dream": "<..> she was his life, The ocean to the river of his 
thoughts, Which terminated all: upon a tone, A touch of hers, his blood would ebb and flow, And his cheek change tempestuously - his heart Unknowing of its cause of agony". Here again, a metaphor is realized implicitly through indirect meanings that are aimed at depicting romantic relationships of lyric heroes. The source concept LIFE serves the basis for creating a metaphoric picture by combining satellitative metaphoric meanings. The connotative meaning of the ocean as the biggest water container underlies a metaphoric mapping. In this way the poet presents the role of a loved woman in life with a strong emotional impact. An analogy between LIFE and OCEAN on the one hand, and THOUGHTS and RIVER on the other, is clearly drawn and similar to how rivers fill the ocean, the thoughts about a woman make sense in life of a romantic hero. This meaning is concentrated in the predicate "terminated" and is extended by a chain of associative images: her tone and touch made his blood ebb and flow. The lexeme "ebb" is used in the marine terminology to describe a water outflow, and indirectly it designates the meaning of dying away, when speaking about life. Thus, WATER and its properties are widely used by Byron to metaphorically represent LIFE.

In the poem "Stanzas To Augusta" binary metaphors LIFE IS LIGHT and DEATH IS DARKNESS are modified into a range of poetic metaphors through the mechanisms of restriction, degradation and combination. "Oh! blest be thine unbroken light! That watched me as a Seraph's eye, And stood between me and the night, For ever shining sweetly nigh. And when the cloud upon us came, Which strove to blacken o'er thy ray-Then purer spread it gentle flame, And dashed the darkness all away." The author regards LIGHT as life stamina capable of conquering DARKNESS and thus fighting DEATH. The poetic image is built on the usage of lexemes with opposing meanings, producing an effect of contrast and adding much to a destructing power of DARKNESS and life-affirming nature of LIGHT that forever shines "sweetly nigh" and stands "between me and the night". A constant struggle between two powers is metaphorically represented in an image of clouds, which "strove to blacken o'er thy ray". However, a poet believed that "gentle flame" "dashed the darkness all away". The actualization of LIGHT 
positive characteristics is done by using attributive lexemes sweetly, purer, gentle that contrast with the lexemes verbalizing DARKNESS: cloud, blacken, night. Metaphorically, death's coldness is night's coldness, since death is night ${ }^{23}$.

The opposition of LIFE and DEATH metaphors is the best realized in "Sun of the Sleepless", in which the images of powerless rays and a cold sun depict a picture of doomsday. Byron combines the depth of thought with an immense feeling of disaster. "Sun of the sleepless! melancholy star! Whose tearful beam glows tremulously far, That show'st the darkness thou canst not dispel, How like art thou to Joy remembered well! So gleams the past, the light of other days, Which shines, but warms not with its powerless rays: A night-beam Sorrow watcheth to behold, Distinct, but distant - clear but, oh how cold!' A basic metaphor LIFE IS THE SUN is realized implicitly through conceptual mechanisms of combination, extension and degradation of the content of a source concept, being expressed by lexemes that verbalize light and its attributes. "Sun of the sleepless!" is a genitive metaphoric construction that contains a complex compressed poetic image, being actualized by extension and combination of a range of metaphoric meanings. Lexemes that designate light properties of the sun occur through the whole poem space. However, their frequent occurrence seeks for creating an opposite effect by degradation the conceptual content of the source concept. The poet calls the sun a "melancholy star! Whose tearful beam glows tremulously far" for it is incapable to dispel the darkness with its "powerless rays". "It is the light of other days" implies the meaning of inevitable darkness that is going to rein. A personified Sorrow becomes the lord of universe and everything is shrouded by night and cold. The analysis done enables us to conclude that the SUN in Byron's conceptual system is tightly connected with the meanings of LIFE. However, the process of metaphors modification involves more the properties of light, warmth and energy. An image of disaster is built on the metaphor of SUN that shines, but does not warm, simultaneously realizing a binary metaphor of DEATH.

${ }^{23}$ Lacoff G., Turner M. More than cool reason: a field guide to poetic metaphor / G. Lacoff, M. Turner. Chicago : University of Chicago Press, 1989. P. 6. 
DEATH is one of the key concepts in E. Dickinson's poetry. However, its metaphors represent different images, which are never repeated. The most frequent proves to be a metaphor DEATH IS A DEPARTURE that undergoes various modifications, demonstrating the poetess's world vision. "Because I could not stop for Death - He kindly stopped for me - The Carriage held but just Ourselves - And Immortality". A poetic metaphor DEATH IS A COACHMAN is made through a conceptual mechanism of restriction and death personification (the usage of a pronoun $\mathrm{He}$ ). The image of "The Carriage held just Ourselves - and Immortality" implies the meaning of a departure with no return. And it is a natural way we perceive of death. As G. Lakoff and M. Turner fairly state that when we read "Because I could not stop for Death - " and understand that what the speaker could not stop are her purposeful activities, we can understand those purposes as destinations and her life as a journey to reach those destinations. The occurrence of the word "Death" in the line suggests the reading that what she declines to stop is her life's journey. The second line, "He kindly stopped for me", and the occurrence of "Carriage" in the third line make it clear that what is being talked about is a journey. Thus, LIFE IS A JOURNEY with a stopping point, and that stopping point is DEATH'S departure point. Consequently, DEATH IS A JOURNEY with a destination $^{24}$.

Like Byron in his poem "Darkness", Dickinson also metaphorically presents DEATH as STILLNESS in the poem "I heard a Fly buzz": "I heard a Fly buzz - when I died - The Stillness in the Room Was like the Stillness in the Air - Between the Heaves of Storm - ". A poetic image of DEATH is built on the meaning of absence of movement, dynamics, on the one hand, and sound - on the other. "A Fly that buzzes", i.e. makes noise, produces a contrast to almost the universal silence that makes everything still, motionless both "in the Room" and "in the Air".

This poem is often seen as a demonstration of Emily Dickinson's style and worldview. It is one of the most famous pieces of synesthesia in Emily Dickinson's poems. The metaphoric image of DEATH represents the

${ }^{24}$ Lacoff G., Turner M. More than cool reason: a field guide to poetic metaphor / G. Lacoff, M. Turner. Chicago : University of Chicago Press, 1989. P. 4 
fusion of color, sound and movement, weakly felt by dying person's senses. The uncertainty of the fly's darting motions parallels her state of mind. Flying between the light and her, it seems to both signal the moment of death and represent the world that she is leaving. The last two lines show the speaker's confusion of her eyes and the windows of the room - a psychologically acute observation because the windows' failure is the failure of her own eyes that she does not want to admit. She is both distancing fear and revealing her detachment from life ${ }^{25}$.

Although the previous poem was written about a carriage ride of eternal death, Emily Dickinson's poem, "I heard a Fly buzz - when I died", is told by a woman who is still speaking and still hearing things upon her death. Because the dead woman can still speak, Dickinson feels that dying is continuous and incessant.

In E. Dickinson's poetry LIFE is conceived of in terms of bodily BONDAGE. The soul of a person leading the life is metaphorically a bound prisoner. Thus, LIFE can be said to imprison the soul in the body. The event of DEATH is metaphorically the event of being released from imprisonment. "Afraid? Of whom am I afraid? Not Death, for who is He? The porter of my father's lodge As much abasheth me..." . This example illustrates the image of DEATH that is metaphorically presented as an escape and a comfortable shutter for a soul. "My father's lodge" is home and the soul's final resting place and "the porter" who ushers you into that home is DEATH personified.

In the poem "I measure every Grief I meet" LIFE is understood in terms of a PAINFUL STATE: "I wonder if it hurts to live - And if They have to try - And whether - could They choose between - It would not be to die - ". A metaphorical predicate "it hurts to live" actualizes the meaning of physical state and a poetic metaphor is created through a conceptual mechanism of degradation as LIFE turns to be painful and full of sufferings.

In the poem "My life had stood - a Loaded Gun" depicts the poetess's metaphorical vision of afterlife. "My life had stood - a Loaded Gun - In

${ }^{25}$ Lundin R. Emily Dickinson and the Art of Belief / R. Lundin. Eerdmans Publishing Co., 2004. P. 56. 
Corners - till a Day The Owner passed - identified - and carried Me away". Again a meaning of departure is central in DEATH image. "And when at Night - Our good Day done - I guard My Master's Head". A LIFETIME IS A DAY metaphor intensifies the meaning of a life's short spin. On the contrary, DEATH IS A NIGHT metaphor implies the idea of birth-death circle, which is impossible to escape.

All of these varied metaphors of DEATH, however, do not truly contradict each other. Death is the ultimate unknowable, and so Dickinson circles around it, painting portraits of each of its many facets, as a way to come as close to knowing it as she can.

It has been assumed that there exist basic conceptual metaphors for understanding LIFE and DEATH that are part of our culture. The Dickinson's poem were chosen "to introduce the range of common, unconscious, automatic basic metaphors which are part of our cultural knowledge and which allow us to communicate with each other, whether in ordinary conversation or in poetry" 26 .

The analysis of conceptual metaphors and modes of their elaboration in romantic poetry makes it clear that LIFE and DEATH metaphors comprise the core of the writers' conceptual system. The most frequent conceptual mechanisms of poetic metaphors modification prove to be degradation, extension and combination. The poetic image is reconstructed in the process of interpretation and analysis of the conceptual content of the source concept, which is, however, predominately actualized in an inner structure of a text, i.e. implicitly.

The conceptual structure of LIFE and DEATH metaphors in G. Byron's and E. Dickinson's poetry is shown in Table 1 below.

The specificity of metaphoric interaction in the author's conceptual system is defined by the so-called "orientators" which determine a choice of a certain image in metaphor. The totality of them composes a number of common schemes that shape a circle of associative and sense-forming links between key concepts. These concepts are considered to be core elements of the author's mental lexicon. And being actualized in a text, they

${ }^{26}$ Lacoff G., Turner M. More than cool reason: a field guide to poetic metaphor / G. Lacoff, M. Turner. Chicago : University of Chicago Press, 1989. P. 15. 
constrain verbal networks, the system of which is conditioned by the author's individual picture of the world.

Table 1

\section{The conceptual structure of LIFE and DEATH metaphors in romantic poetry}

\begin{tabular}{|c|c|c|c|c|}
\hline \multirow{2}{*}{ 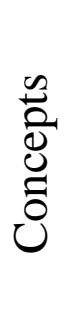 } & \multicolumn{2}{|c|}{$\begin{array}{l}\text { Conceptual metaphors } \\
\text { in Byron's poetry }\end{array}$} & \multicolumn{2}{|c|}{$\begin{array}{l}\text { Conceptual metaphors } \\
\text { in Dickinson's poetry }\end{array}$} \\
\hline & $\begin{array}{c}\text { Basic } \\
\text { conceptual } \\
\text { metaphors }\end{array}$ & $\begin{array}{c}\text { Poetic } \\
\text { conceptual } \\
\text { metaphors }\end{array}$ & $\begin{array}{c}\text { Basic } \\
\text { conceptual } \\
\text { metaphors }\end{array}$ & $\begin{array}{c}\text { Poetic } \\
\text { conceptual } \\
\text { metaphors }\end{array}$ \\
\hline 岌 & $\begin{array}{l}\text { LIFE IS A } \\
\text { ROAD } \\
\text { LIFE IS } \\
\text { WATER } \\
\text { LIFE IS } \\
\text { MOVEMENT } \\
\text { LIFE IS LIGHT } \\
\text { LIFE IS THE } \\
\text { SUN }\end{array}$ & $\begin{array}{l}\text { LIFE IS A } \\
\text { DULL ROAD, } \\
\text { LIFE IS A DIM } \\
\text { ROAD, LIFE IS } \\
\text { A DIRTY } \\
\text { ROAD } \\
\text { LIFE IS AN } \\
\text { OCEAN } \\
\text { LIFE IS } \\
\text { WARMTH }\end{array}$ & $\begin{array}{l}\text { LIFE IS A } \\
\text { JOURNEY } \\
\text { LIFE IS A } \\
\text { BURDEN } \\
\text { LIFETIME IS A } \\
\text { DAY }\end{array}$ & $\begin{array}{l}\text { LIFE IS A } \\
\text { PAINFUL } \\
\text { STATE } \\
\text { LIFE IS A } \\
\text { BODILY } \\
\text { BONDAGE }\end{array}$ \\
\hline 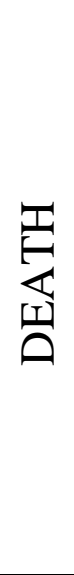 & $\begin{array}{l}\text { DEATH IS A } \\
\text { STOP } \\
\text { DEATH IS } \\
\text { NIGHT }\end{array}$ & $\begin{array}{l}\text { DEATH IS } \\
\text { STILL WATER } \\
\text { DEATH IS } \\
\text { DARKNESS } \\
\text { DEATH IS } \\
\text { COLD LIGHT } \\
\text { DEATH IS THE } \\
\text { RAYLESS SUN }\end{array}$ & $\begin{array}{l}\text { DEATH IS A } \\
\text { DEPARTURE } \\
\text { DEATH IS A } \\
\text { FINAL } \\
\text { DESTINATION } \\
\text { DEATH IS A } \\
\text { STOP } \\
\text { DEATH IS A } \\
\text { NIGHT }\end{array}$ & $\begin{array}{l}\text { DEATH IS A } \\
\text { COACHMAN } \\
\text { DEATH IS } \\
\text { HOME } \\
\text { DEATH IS AN } \\
\text { ESCAPE } \\
\text { FROM } \\
\text { SUFFERINGS } \\
\text { DEATH IS } \\
\text { STILLNESS }\end{array}$ \\
\hline
\end{tabular}

Being a model of concepts interaction, a metaphor forms an inseparable unity with the author's conceptual system. On the one hand, to study the mechanisms of metaphor creation and function it is necessary to consider the author's conceptual system. On the other hand, the research of metaphoric nomination can serve the basis for the study of this system organization and principles of its modeling. 


\section{CONCLUSIONS}

The research deals with the study of cognitive and psychological nature of metaphor and modes of its elaboration in romantic poetry. It is important to distinguish the way we conceive metaphorically from the way writers express such thoughts in their language. General conceptual metaphors are not the unique creation of individual poets, but are rather part of the way members of a culture have of conceptualizing their experience. Poets, as members of their cultures, naturally make use of these basic conceptual metaphors to communicate with their audience ${ }^{27}$. In addition to elaborating conventional metaphor, a poet goes beyond the normal use of conventional metaphor to point out and call into question the boundaries of our everyday metaphorical understandings of important concepts.

The attempt has been made to prove that any literary text reflects author's individual conceptual system, created by his/her artistic imagination and embodied with purposefully selected language means. Being a preferable language means in a dense poetic text, metaphor brings to the fore the importance of studying modes of its elaboration that reveal author's individual choice of image presentation. As far as a poetic metaphor is created and transmitted by an image, it undoubtedly appeals to emotions and text perception. Therefore, the image has a special status, "intermediate" between the verbal and nonverbal aspects of metaphorical expression. Metaphor is regarded as an illustration of rethinking of the linguistic forms. The choice of a certain image in metaphor is associated with the author's world vision and the system of stereotypical images. It has also been emphasized that poetry represents some artistic space in which metaphors undergo modifications and turn into complex poetic images.

In their turn, poetic metaphors have been viewed as an evidence of the individual mode of perception, organization and processing the artistic reality. Reflecting the dynamics of the interaction between conceptual and linguistic spheres, poetic metaphor is a unique tool for modeling the

${ }^{27}$ Lacoff G., Turner M. More than cool reason: a field guide to poetic metaphor / G. Lacoff, M. Turner. Chicago : University of Chicago Press, 1989. P. 9. 
individual world vision of the author. By means of a literary text, which is the result of the linguistic and cognitive activities, the author verbalizes his/her linguistic picture of the world. Thus, metaphor is fairly considered to be a core element in the author's individual conceptual system and cognitive style.

\section{SUMMARY}

The cognitive and psychological aspects of metaphor and its role in the author's conceptual system in poetry have been in the limelight of this research. The DEATH and LIFE metaphors have been studied from the perspectives of cognitive mechanisms of their creation and modification in romantic poetry. Besides metaphors have been regarded as a conceptual basis of verbal poetic images, created by the author to model a conceptual space of a poem and produce an impact on a reader.

\section{REFERENCES}

1. Арутюнова Н. Д. Метафора и дискурс / Н. Д. Арутюнова ; [пер. с анг., фр., нем., исп., польск. яз., общ. ред. Н. Д. Арутюновой и М. А. Журинской] // Теория метафоры : сборник. М. : Прогресс, 1990. C. 5-32.

2. Башляр Г. Фрагменти Поетики Вогню / Густав Башляр ; [пер. 3 фр.]. Харків : Фоліо, 2004. 143 с.

3. Бєлєхова Л. І. Словесний поетичний образ в історикотипологічній перспективі : Лінгвокогнітивний аспект (на матеріалі американської поезії) / Лариса Іванівна Бєлєхова. К. : Вид. центр КНЛУ, 2002. 368 с.

4. Воробйова О. П. Когнітивна поетика : здобутки і перспективи / О. П. Воробйова // Вісник ХНУ ім. В. Н. Каразіна. Ювілейний збірник “200-річчя Харківської мовознавчої школи”. Харків : Константа, 2004. № 635. С. 18-22.

5. Добжинская Т. Мой интимный маленький мир и поэтические способы концептуализации: Метафора / Т. Добжинская // Слово в тексте и в словаре. Сб. ст. к семидесятилетию акад. Ю. Д. Апресяна. Москва : Языки русской культуры, 2000. С. 529-537. 
6. Ніконова В. Г. Трагедійна картина світу в поетиці Шекспіра : монографія / В. Г. Ніконова. Дніпропетровськ : Вид-во ДУЕП, 2007. $364 \mathrm{c}$.

7. Никитин М. В. Основания когнитивной семантики / М. В. Никитин. СПб. : Изд-во РГПУ им. А. И. Герцена, 2003. 277 с.

8. Павличко С. Д. Байрон. Нарис життя і творчості / Соломія Дмитрівна Павличко // Зарубіжна література : Дослідження та критичні статті. К. : Вид-во Соломії Павличко “Основи”, 2001. C. $153-270$.

9. Постовалова В. И. Картина мира в жизнедеятельности человека / В. И. Постовалова. М. : Наука, 1988. С. 8-69.

10. Рикёр П. Метафорический процесс как познание, воображение и ощущение / П. Рикер ; [пер. с анг., фр., нем., исп., польск. яз., общ. ред. Н. Д. Арутюновой и М. А. Журинской] // Теория метафоры : сборник. М. : Прогресс, 1990. С. 416-434.

11. Фрумкина Р. М. Психолингвистика / Р. М. Фрумкина. Москва : Академия. 2001. 320 с.

12. Byron G. Selections From Byron. Lyrical Verse / G. Byron. Moscow: Progress Publishers, 1979. 520 p.

13. Dickinson E. The Selected Poems by Emily Dickinson / E. Dickinson. Hertfordshire : Wordsworth Editions Ltd, 1994. 214 p.

14. Freeman M. Poetry and the Scope of Metaphor : Toward a Cognitive Theory of Literature / M. Freeman // Metaphor and Metonymy at the Crossroad: A Cognitive Perspective / Ed. Barcelona A. Berlin ; N.Y. : Mouton de Gruyter, 2000. P. 253-283.

15. Freeman M. The Body in the World: A Cognitive Approach to the Shape of a Poetic Text / M. Freeman // Cognitive Stylistics : Language and Cognition in Text Analysis / Ed. by E.Semino, J.V. Culpeper. Amsterdam ; Philadelphia : John Benjamin's Publishing House, 2002. P. 23-48.

16. Gibbs R. W. The Poetics of Mind : Figurative Thought, Language and Understanding / R. W. Gibbs. Cambridge: Cambridge University Press, 1999. 527 p.

17. Hester M. B. An Analysis of the Meaning of Poetical Metaphor / M. B. Hester. L., 1964. 316 p. 
18. Lacoff G., Johnson M. Metaphors We Live By / G. Lacoff, M. Johnson. Chicago : The University of Chicago Press, 1980. 240 p.

19. Lacoff G., Turner M. More than cool reason: a field guide to poetic metaphor / G. Lacoff, M. Turner. Chicago : University of Chicago Press, $1989.230 \mathrm{p}$.

20. Lundin R. Emily Dickinson and the Art of Belief / R. Lundin. Eerdmans Publishing Co., 2004. 348 p.

21. Siroka D. A Linguistic Picture of the World and Expression of Emotions through the Prism of Expressive Lexis / D. Siroka // Journal of Education Culture and Society. 2013. № 2. P. 297-308.

22. Stockwell P. Cognitive Poetics: An Introduction / P. Stockwell. L.; N.Y. : Routledge Taylor \& Francis Group, 2002. 189 p.

23. Tsur R. Toward a Theory of Cognitive Poetics / R. Tsur. Amsterdam: Elsevier Science Publishers, 1992. 214 p.

\section{Information about the author:} Chendey N. V.,

Candidate of Philological Sciences in Comparative Linguistics, Associate Professor at the Department of English Philology Uzhhorod National University 14, office 539, Universytetska str., 88000, Uzhhorod, Zakarpattia region 


\section{SPEECH ACCENT IN BILINGUALS' SPEECH}

\section{Devitska A. I.}

\section{INTRODUCTION}

Pronunciation accent is a complex phenomenon of speech and it is created through a combination of phonetic characteristics of speech. Deviations from the pronunciation standard in the speaker's non-native speech, on the one hand, have certain peculiarities, reflecting linguistic, national, social as well as territorial identity of the person speaking with an accent.

However, speech accent is at the same time marked by common characteristics typical of any person who speaks a non-native language and does not speak it perfectly due to the lack of speaking skills, due to a certain psychological barrier when switching to a non-native language in communication, as well as for a number of other reasons, which are not identified yet. Another significant aspect in pronunciation accent is that both general and specific signs of pronunciation norm violation in bilingual's speech in an acquired language make up a general picture of accented speech (speech colored with an accent) in native speaker's perception and linguistic consciousness.

Naturally, the deviations in pronunciation are observed both at the segment (sound) and suprasegmental (prosodic) levels of speech. The least studied area of accented speech, and therefore the most vulnerable in practical terms, is considered to be the intonational pattern of foreign speech. In our opinion, the study of a foreign accent in bilinguals' speech at the prosodic level is of high importance, since the accented speech is especially "betraying" a speaker in a foreign language in larger units, especially in longer utterances. At the same time, errors in word, phrase stress distribution, as well as in defining the intonation center in the phrase are vivid markers of bilinguals' accented speech. 


\section{Specificity of bilinguals' speech}

Current process of international globalization and integration make the research of ethnic and cultural specifics as first-rate. The studies of intercultural communication today are represented in the scientific works of many linguists.

It has commonly been assumed that, intercultural contacts depend on the ability of the participants to understand each other and reach an agreement. Those factors are defined mostly by ethnic culture of each part that interacts as well as nations' psychological and cultural values they possess. Therefore, intercultural communication can be observed as native speakers' contact, which results phonetic interference on different levels. Thus, phonetic interference causes the difficulty of perception and production of bilinguals' speech.

In terms of intercultural communication there appears an interaction between language maps of the world as well as their part which is national specific one. We consider intercultural communication as the interaction of different cultures, that is conceptualized by different language systems. Finally, intercultural communication is as interaction of national specific part of language maps of the world, in which the citizens share mutual sociocultural space.

Transformational processes in European Union's countries, namely Slovakia, have contributed to the demand for information on the culture, the strengthening of the communicative positions of the Slovak language, and with the country's accession to the European Union - the joint functioning of the Slovak and English languages as the main communicative partners in a single socio-linguistic space.

These processes also contributed to the formation of young Slovaks in the world, increased their interest in mastering the Slovak language, attracting historical, cultural, ethnographic material, as well as thorough study of the worldview of Slovaks and more. As a result, those changes affect the role of communication participants, especially those immigrants to the United Kingdom.

We should note that a characteristic feature of Slovakia is the collective bilingualism and multilingualism of indigenous peoples. Thus, 
the Slovaks living in Bratislava Region are considered to be SlovakEnglish-Hungarian-Czech-German bilinguals, while the residents of Kosice region - Slovak-Ukrainian-Russian, Banska-Bystrica region Slovak-English-Czech-Hungarian-Russian bilinguals. Mainly, after the country's accession to the European community, the influence of English on the Slovak language has increased. As a result, young people have begun to actively use English instead of existing Slovak counterparts in everyday communication, to study English at language courses at universities, to travel to the United Kingdom, gradually improving their English skills, as well as immigrate to UK.

Thus, the intercultural communication of the Slovaks is a form of communication among the population in this region, in which the ways of realization of different situations by different cultures appear to be not identical, that is, there are differences in their implementation and interpretation. The multi-ethnicity, multilingualism, multiculturalism and multimentality of the Slovak population formed a new educational space multicultural. Besides, awareness of the importance of cultural and historical factors in the processes of communication, knowledge and adequate behavior of the representatives of different ethnic groups contributes to the success in intercultural communication, because the process of communication requires mutual understanding and mutual adaptation of the interlocutors.

Particular attention should be paid to empathy - the ability to understand other people, their thoughts as well as feelings. Personality as a subject of communication becomes real and effective only when the community has a developed reflection - the ability to perceive yourself as a self-enhancing personality. The most important component of a communicative culture of intercultural communication is language mastering.

The term "accent" (lat. accentus - accent) was previously associated with the selection of individual elements in the speech flow (vowels, syllables, words, parts of phrases) by the means of voice. However, in modern linguistics, this term denotes not only the emphasis in a word or phrase, but is also used to describe the particular character of the 
pronunciation of a speaker who does not have a common spoken language standard. Actually, nowadays the term "foreign accent" is commonly associated with the pronunciation of a speaker in a non-native language.

During the first stage of our experimental research, which included auditory analysis, the experimental material selected was listened by English-speaking informants, naive users, and phoneticians with experience of audio-language texts auditing in order to obtain data and establish the peculiarities of the suprasegmental characteristics of English spoken by the Slovaks, who immigrated to the United Kingdom.

With the help of a special questionnaire, created by the author, the auditors, naive English speakers, were offered mainly to establish the natural sounding of experimental material corpus and its compliance with Received Pronunciation (RP). Noticebly, Received Pronunciation is a way of pronouncing British English that is used as a standard in the teaching of English as a foreign language ${ }^{1}$.

Secondly, native speakers were not only to identify standard and interfered statements, but also to find out the speaker's accent, the clarity of his / her pronunciation, the clarity of the perceived text, to determine the nationality of the speaker or his / her origin (native English speaker, the Slovak, other origin), as well as to establish the presence / absence of education (secondary, higher), to find out the social status of the speaker (student, volunteer, member of public organization, member of parliament, social worker, scientist, etc.), identify his / her affiliation with a specific professional group (foreign language specialist / non-specialist).

According to auditory analysis data, naive users of English qualified $80.04 \%$ of the texts narrated by the Slovak speakers as acceptable, including $32.06 \%$ of the fragments that had a natural sounding and conformed to the English standard pronunciation. At the same time, $47.98 \%$ of the texts narrated were perceived by the auditors as natural with minor deviations and violations of the reference language, and $19.96 \%$ were considered as unnatural with significant deviations from the English standard.

\footnotetext{
${ }^{1}$ https://www.collinsdictionary.com/dictionary/english/received-pronunciation
} 
In this regard, it turns out that $12.52 \%$ of the statements realized by native English speakers were defined as standard ones, $87.48 \%$ of the total amount of experimental material corpus were interfered statements, narrated by the Slovak speakers of English. This very data enabled us to establish a combination of suprasegmental means which are invariant for the Slovaks, irrespective their residence duration in the United Kingdom, their degree in education, professional background, etc., and also those suprasegmentals depend on the level of interference in English spoken by the Slovaks.

The auditors rated the English speech of the Slovaks as low level of mastering it that makes $12 \%$ of the total amount of the utterances. Expressions which were characterized by a high level of foreign language competence accounted for 25\%. The largest number of utterances pronounced by the Slovaks had intermediate level of proficiency in English (63\%).

According to auditory analysis findings, the deviations from the English pronunciation standard established during listening to fragments were perceived as the markers of phonetic interference in English spoken by the Slovaks.

While determining the nationality of the speaker, half of the total number of auditors, naïve speakers, classified 30\% of the speakers as people of Czech nationality and, accordingly, stated Czech variant of English language (Czenglish); $25 \%$ of auditors qualified $30 \%$ of speakers as Ukrainians and Poles, that is the speakers of Ukrainian and Polish accents (Ukrainglish, Poglish). The other $25 \%$ of auditors perceived $40 \%$ of speakers as persons of Slovak origin, speakers of Slovak accent in English (Slovglish). Therefore, we may suggest that the Slovak language influences significantly the pronunciation of English spoken by the Slovaks as well as helps to determine the degree of interference in their speech.

The following part of this paper moves on to describe in greater detail the information on the availability / lack of speakers' education (secondary or higher) which seemed interesting. The majority of informants $(82 \%)$ attributed $62 \%$ of the speakers to those with higher 
education, and $38 \%$ to persons with secondary education. At the same time, $18 \%$ of naive users qualified the speech of $42 \%$ of speakers as those having a scientific degree and, accordingly, $58 \%$ of speakers with secondary education.

The analysis conducted has highlighted the differences in indicators mentioned in questionnaires data of the Slovaks and the auditors, naive English users. Thus, according to the analysis of the questionnaires of the Slovak speakers, $41 \%$ of them have higher education, $29.5 \%$ indicated postgraduate education and the remaining $29.5 \%$ of Slovaks noted secondary education.

In addition, naïve users of English were asked to find out the social status of the Slovak speakers. Thus, $32.64 \%$ of naive users stated that $35 \%$ of the Slovak speakers are entrepreneurs or workers for non-governmental organizations, and the majority $(65 \%)$ is made by the students. The results of the second part of the naïve users of English (67.36\%) are somewhat different: they qualified the English speech of the Slovaks as those of civil servants $(51.15 \%)$, scientists $(22.45 \%)$, volunteers $(13.20 \%)$ and the unemployed (13.20\%).

In terms of establishing the data as a specialist / non-specialist in foreign language reports indicated that $80.04 \%$ of the speakers were perceived by native speakers as foreign language specialists (in English), whereas $19.96 \%$ were recognized as non-specialists. Unlike the results of the naïve speakers, the Slovaks indicated their degree of English speaking as follows: $50 \%$ - upper intermediate, $25 \%$ - intermediate, $25 \%$ - preintermediate.

The above mentioned data indicates that the number of texts examined, which were fully understood by the auditors, makes $32.06 \%$, whereas misunderstood texts, narrated with some errors, including pronouncements that interfere with and influence the perception of the content, account for $47.98 \%$. The remaining $19.19 \%$ of the total number of texts heard were those that were qualified as misunderstood and narrated with significant errors in utterance pronunciation and intonation. Such texts have been removed from further analysis. 


\section{Bilinguals' English speech analysis}

According to the methodology of experimental phonetic research, the phoneticians analyzed the corpus of experimental material selected in the first stage and aimed to establish the adequacy of the intonational organization of the narrated text according to the orthoepic norm of British English, to highlight the clarity of the English pronunciation when narrating literary texts, to state the degree of phonetic interference in English speech of the Slovaks.

Similarly, the phoneticians were to find out the quality of conveying the text context by means of intonation, to check availability and degree of emotional component conveying in the voiced text (high, medium, low), to establish the correctness of pragmatic purpose in the narrated text. During the auditive analysis, three stages of phonetic interference (low, medium, high) were identified by the phoneticians.

According to the information provided by the informant auditors, $28.09 \%$ of the narrated text fragments were characterized by a high degree of phonetic interference. In $42.24 \%$ of the texts perceived by the informants, phonetic interference was qualified as medium, whereas low degree of phonetic interference was attributed to $29.67 \%$ of the total texts analyzed.

At the same time, native speakers have noted that the English speech of the Slovaks with low and medium level of language competence sounds not very natural and a significant influence of the native language is felt, whereas those speakers with a high level of English proficiency have little influence of their native language in their English speech. Thus, we may suggests that the degree of phonetic interference manifestation in English spoken by the Slovaks can be qualified as high, medium, and low, which is inversely proportional to the low, medium, and high levels of English language competence of the speakers.

A more detailed account of prosody in accented English speech of the Slovaks is given in the following section. Auditive analysis of the prosodic characteristics of English spoken by the Slovaks also revealed that all Slovak speakers, regardless of their residence duration in both Slovakia and the United Kingdom, of their level of education, professional 
background, etc., made mistakes in the pronunciation of individual sounds, words, and the intonational organization of their utterances did not always correspond to the reference sample, narrated by native English speakers.

Therefore, the most typical violations on suprasegmental level in English utterances pronounced by the Slovaks included the following:

1) the intonational pattern of main and secondary information was not always adequate;

2) no variation in tone levels, tempo and volume in expressing semantic contrast in expression;

3) excessive use of stress on each word in the intonation group, monotonous manner of sounding, desire to highlight each word in the phrase;

4) usage of a considerable number of pauses of different duration, etc.

Particular attention of philologists, the auditors, was attracted by the incorrect formation of the melodic contour, namely the use of a high beginning in the intonation group instead of a low or medium one in the realizations actualized by the Slovak speakers of English.

Remarkably, the native speakers of the English language noted that such violations impeded the perception of the literary work, in some cases made it impossible to understand the meaning of the expression and influenced the conveying of the pragmatic purpose in literary text. Mainly, the decoding of the statements' content perceived by the auditors was largely influenced by the incorrectness of the statements' division into semantic groups, as well as by the lack of correlation of the content with the degree of emotional aspect of the expression.

According to the analysis of the degree of prosodic interference manifestation, only $29.67 \%$ of the interfering expressions of the narrated literary texts coincide by the number of intonation groups with similar reference samples, $42.24 \%$ of the statements are marked by slight deviations of the separation of the analyzed statements on semantic groups, while $28.09 \%$ of utterances have complete inconsistency on this trait in comparison with reference samples.

During the auditive analysis, the informants with philological training identified some violations of the rhythmic organization of the statements, 
deviations in tempo and volume of speech, the distribution of phrase stress, which together led to errors in actual phrase stress and affected the convey of meaning and the degree of expression of pragmatic sense. In addition, native speakers noted in the comments to the protocols that such incorrect rhythmic organization of the narrated text sounded unnatural and monotonous and it was difficult to perceive it.

Moreover, the decoding of the content of the interfered fragments perceived by the auditors informants was greatly influenced by the incorrectness of the utterances division on the sense groups, as well as by the lack of correlation of the content with the degree of expression of the meaning of the literary text.

Another example of the fragments narrated by native English speakers and the speakers of Slovak language regarding the correctness of the convey of their meaning by means of intonation, allowed to establish the degree of expression of emotional and pragmatic potential by the speakers in standard and interfered utterances as well as the conformity of the intonation design of the interfered statements to their pragmatic purpose and emotional saturation.

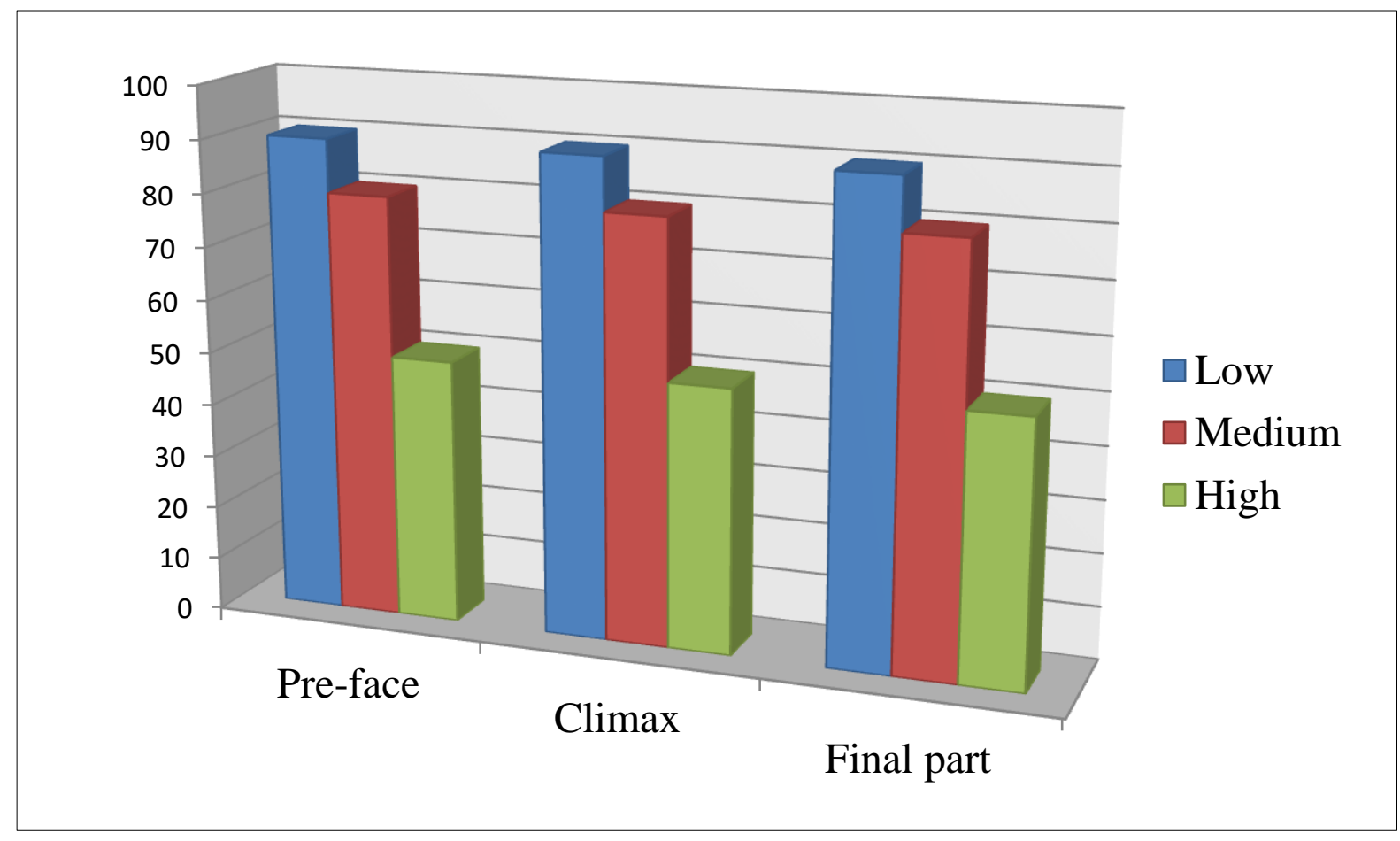

Pic. 1. The level of utterance meaning convey by means of intonation (according to bilinguals' data) 
The results showed that the expression of the degree of emotional and pragmatic potential of the literary texts' fragments narrated by the speakers of Slovak is inversely proportional to the degree of utterances' interference: the lower the degree of phonetic interference manifestation, the higher the degree of emotionally pragmatic expression of the text and vice versa.

Thus, fragments of the text, narrated by the Slovak speakers with a low degree of phonetic interference, have been qualified as those having an intonational design that corresponds to their pragmatic purpose and emotional saturation and has a high level of meaning convey.

In contrast, we present the results of auditive analysis by phonetic auditors, professional phoneticians, who have evaluated the degree of meaning and emotionally pragmatic expression transmission by means of intonation as follows:

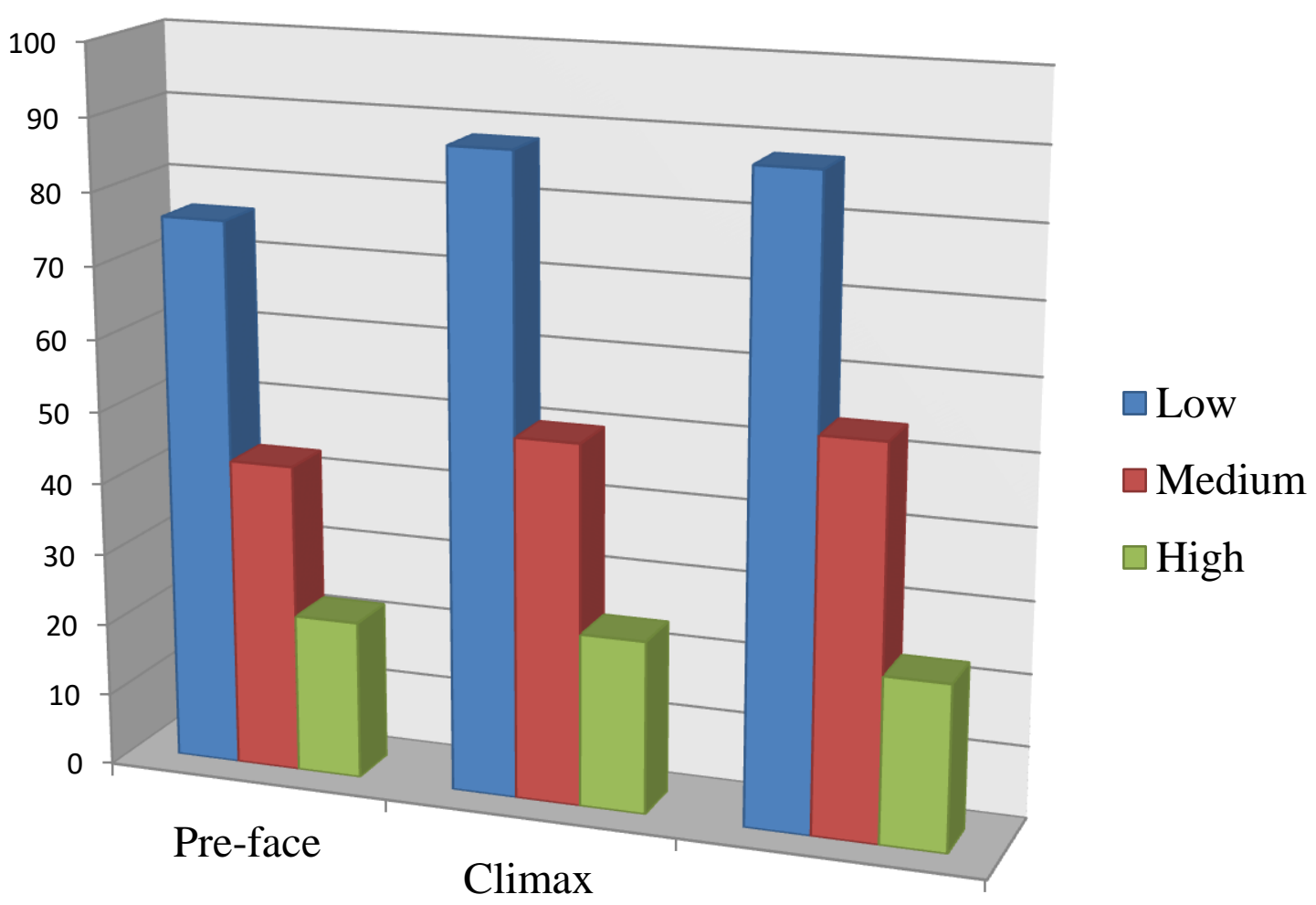

Final part

Pic. 2. The level of meaning and emotionally pragmatic expression convey (according to phonetic auditors, professional phoneticians' data) 
Particular deviations from the English language standard did not prevent the English-speaking auditors from determining the pragmatic content of the fragments of narrated literary texts. Minor deviations of intonational expression of pragmatic sense convey and the emotional saturation of the literary texts is inherent in bilingual Slovak speakers with a medium degree of phonetic interference, whereas the level of meaning covey is qualified as medium.

This is due, on the one hand, to a lack of understanding of the meaning of the entire text or a single sentence, on the other, there is a lack of skills in reading in English and the ability to narrate literary texts.

A high degree of phonetic interference was recorded in the group of the Slovaks whose intonation contour, as well as the expression of its pragmatic purpose and emotional saturation of a sense of expression did not respond the situation.

In this case, the degree of conveying the pragmatic context of the narrated fragment was acknowledged as low. Moreover, the deviations from the literary standard in the pronunciation of the Slovaks on segment level created additional difficulties in the perception of the texts narrated by them.

Thus, we can conclude that the results, performed in terms of auditive analysis of the experimental material by the auditors with the philological preparation allow us to establish the degrees of phonetic interference in the English pronunciation of the Slovak speakers and to divide them into the appropriate groups (high, medium, low) for the next stage of experimentalphonetic study, namely the analysis of the selected case of experimental material by phoneticians, the auditors.

Therefore, observing and analyzing specially designed questionnaires for the Slovaks, the participants of the experiment, allowed to trace the extinguishing characteristics typical of immigrants. It was found out that the Slovaks who immigrated and lived in the UK, they study a second language in the immediate sociocultural context of communicating with its speakers and have a natural bilingualism, which in its turn makes it possible to form bilingualism. Thus, in the process of foreign language communication of Slovaks a low degree of phonetic interference is observed. 
At the same time, we have established the type of bilingualism in Slovak-speakers according to the scope of use of two languages (Slovak and English) and determining their value orientation. Thus, $85.63 \%$ of Slovaks argued that they use English daily at work, in public transport, on vacation, sometimes at home, during business meetings and on business trips, whereas, they communicate in Slovak language mostly with family, at home, with friends, on vacation, etc. This leads to the conclusion, that $85.63 \%$ of the speakers belong to a vertical type of bilingualism, which prefers to use the literary language and the dialect of one language. At the same time, one language is preferred over the native values scale.

In contrast, $14.37 \%$ of the Slovak speakers of English mentioned that they use English only in public transport, in everyday communication situations, etc., whereas at work, at home, with their family they speak only Slovak. In addition, the above-mentioned speakers added comments on the value orientation of the language in their comments to the questionnaires and determined which speakers they consider themselves to be.

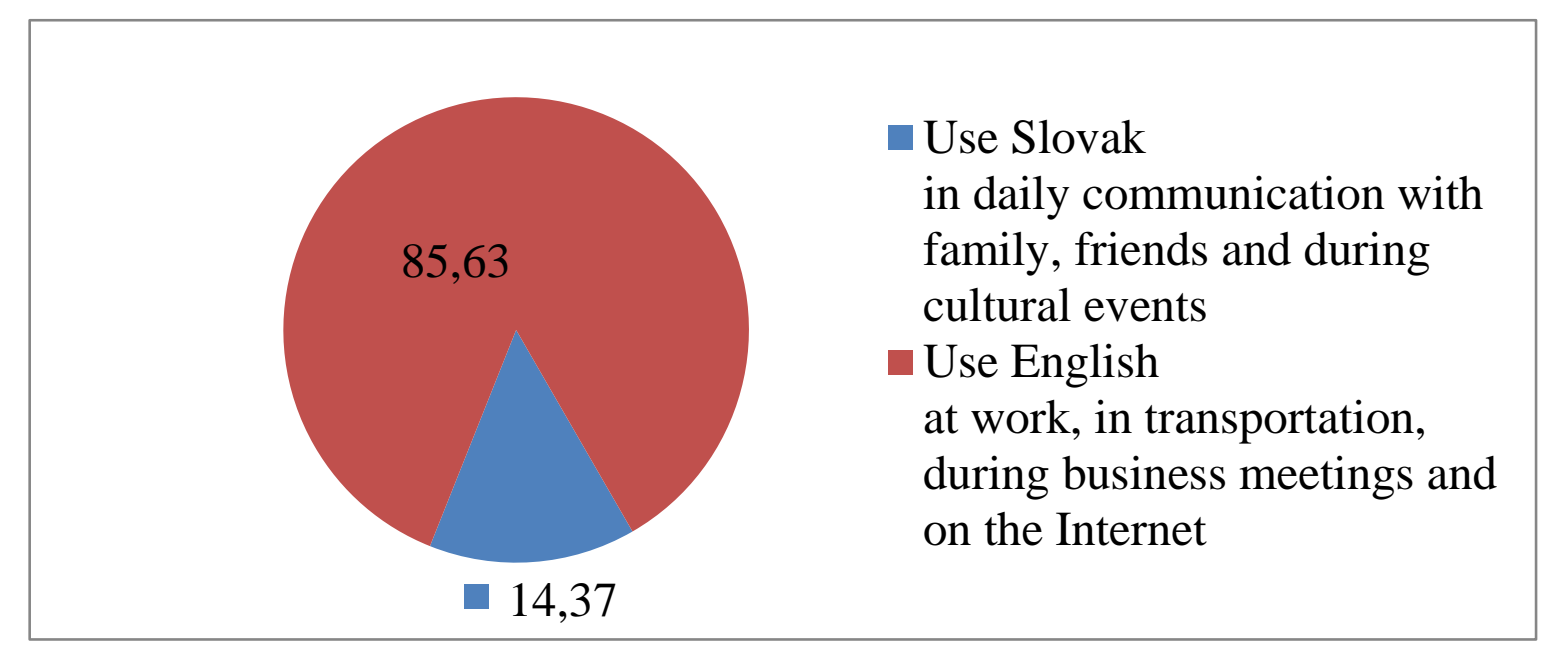

\section{Pic. 3. English and Slovak Language usage in United Kingdom (among the Slovaks, immigrants to United Kingdom).}

Thus, $85,63 \%$ of those who were interviewed, indicated that they use English at work, in transportation, during business meetings and on the Internet. Approximately $14,37 \%$ of those who responded that they use Slovak language in daily communication with family, friends and during cultural events. 
This interpretation contrasts from that of informants, as bilingual speakers indicated their English language proficiency as follows: 50\% upper intermediate, $25 \%$ - intermediate and $25 \%$ - pre-intermediate respectively. Therefore, the total number of bilingual Slovaks, the speakers of English, with a certificate of language competence makes $34 \%$ of the respondents.

Since the duration of learning and using English language by bilinguals is of high importance in our study, it is appropriate to summarize the results of these data. Most of the respondents (50\% of total amount of the speakers) argued that they had been learning English since childhood, $25 \%$ of the speakers mentioned over 15 years and the rest $25 \%$ of the speakers stated that they had been learning English during past 10 years.

With regard to the duration of English usage by the respondents, the data obtained were as follows: $60 \%$ of the speakers use English more than 15 years, $23 \%$ of the speakers have been using English during past five years, another $25 \%$ of the speakers have been using English more than 10 years. At the same time, the speakers were asked to indicate the level of language competence in their native language, the Slovak. It is worth noting, that all bilinguals have qualified their level of Slovak language as the highest, including even those respondents who have lived in the UK for over 20 years, which is indicative of linguistic patriotism, that respectively results in a value orientation in language priority for immigrant bilinguals.

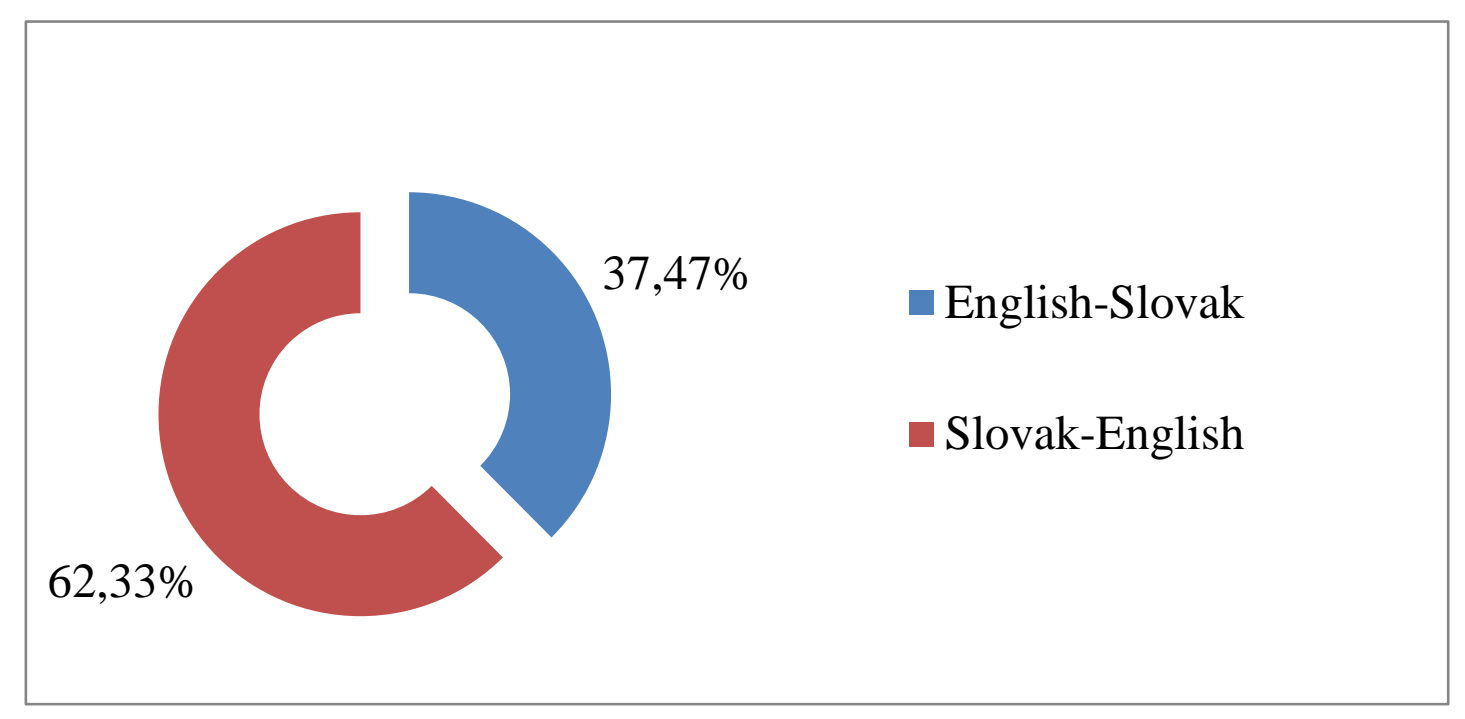

Pic. 4. Value orientation in language choices 
The majority of the speakers consider themselves to be EnglishSlovak bilinguals $(62,33 \%)$ despite the fact that they speak English daily in all possible areas, whereas the second group of the speakers $(37.67 \%)$ uses Slovak on every occasion, $14 \%$ of the speakers said that when producing English, they think in Slovak, and that interpreting from English into Slovak and vice versa is of great complexity for them.

As an example, we may look through the bilingual speakers' responses to the situations in which they switch to Slovak. Therefore, for example, 35, $78 \%$ of respondents proved that they alternate Slovak and English when they are in a state of stress, depression, sorrow, disappointment, disgust and frustration. While the speakers who switch to Slovak after English in a state of excitement, excessive astonishment, happiness, encouragement, harmony and joy make up 42, $95 \%$.

Another group of bilingual speakers that make $18.03 \%$ commented that they use Slovak in any unexpected, unknown and strange situations. These findings have significant implications for the understanding of how such a situational switching from one language to another may be related, first of all, to the level of foreign culture perception or non-acceptance by bilinguals.
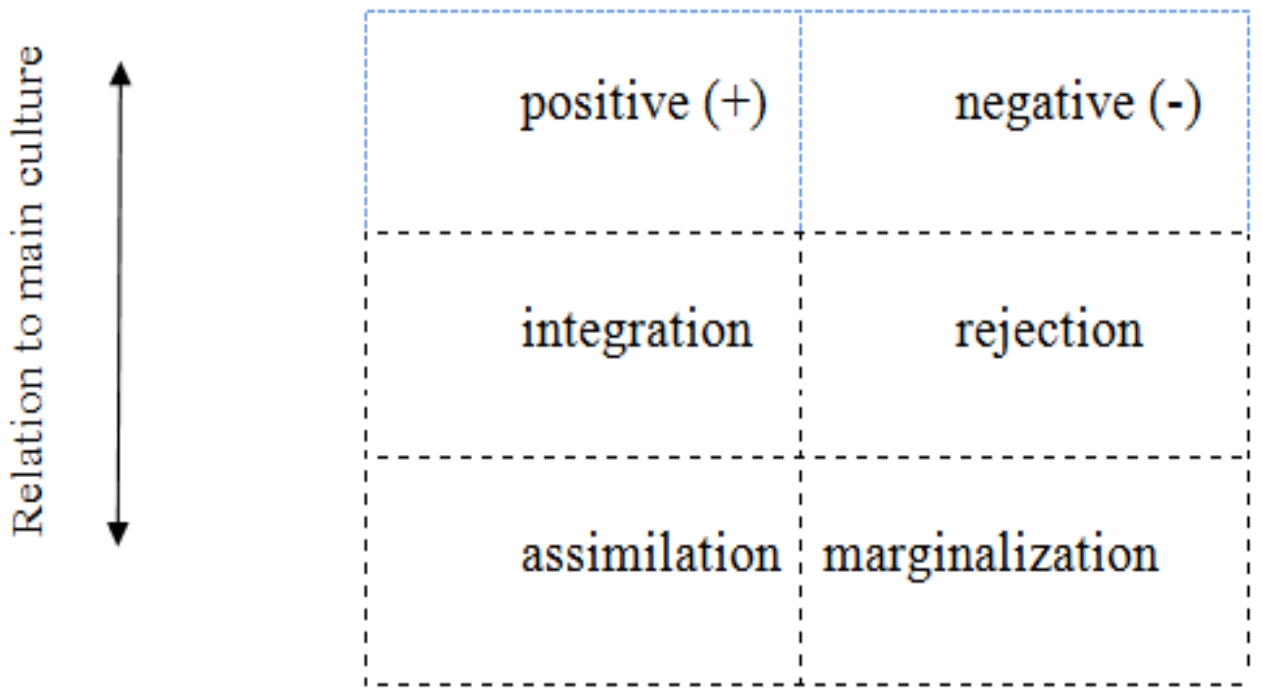

Pic. 5. Perception / non-perception of foreign culture by bilinguals 
From the entire volume of the material, we selected the most common fragments of literary texts with a duration of 4-5.5 minutes each to achieve the goals of the experiment. The narration was delivered by bilingual speakers of English, the Slovaks, who have experience in narrating texts. Speakers were consulted prior to recording texts due to the purpose of the experiment. The bilinguals had time to prepare before reading the texts. Each speaker agreed to use the recording of his speech in the experiment.

The speakers were selected using a specially designed questionnaire according to the following criteria: age, nationality, place of birth, place of their parents' birth, current place of residence, place of the longest residence, education, conditions and duration of learning English, conditions and duration of learning Slovak language, profession, social status, status of English as a native or foreign language, etc.

Level of English proficiency among Slovak-English bilinguals

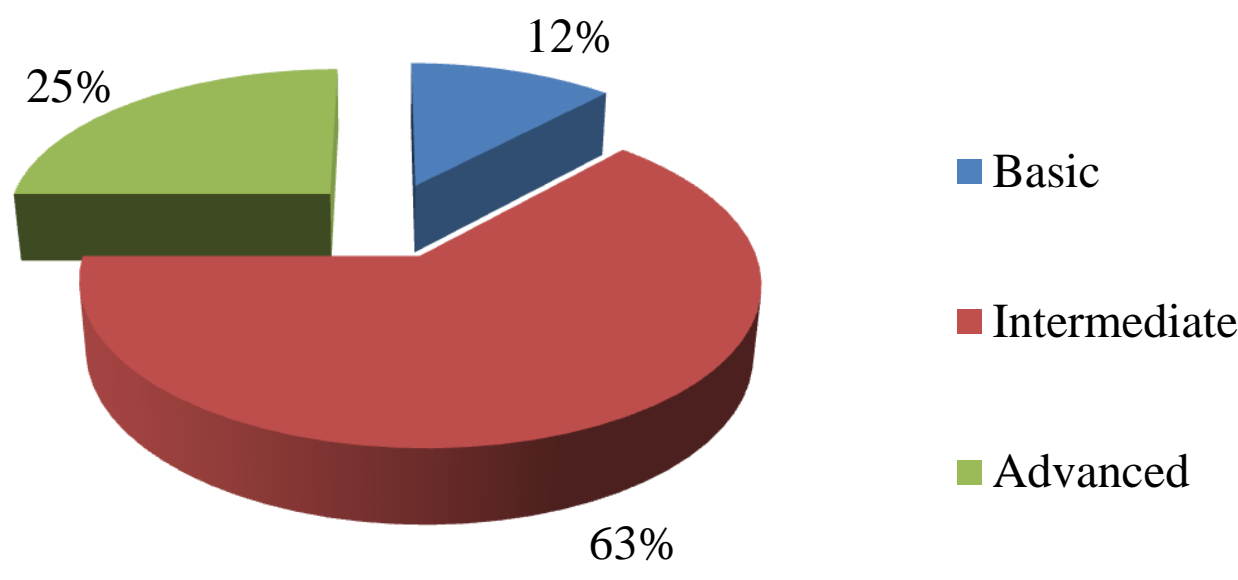

\section{Pic. 6. Level of English language proficiency among Slovak-English bilinguals}

Thereore, 19 people were selected as the narrators for the experiment: 8 men and 11 women. It should be noted that in this experiment, the analysis of gender features of English language was not intended. Also, the experimental material was narrated by native speakers of English who have a standard British pronunciation (Received Pronunciation) and the Slovaks who live both in Slovakia and those, who immigrated to the United Kingdom. 
The basis of the analyzed material made audio recordings of excerpts read by indigenous British speakers with standard British English pronunciation. Two texts were narrated by British actor and storyteller Robert Glenister, who has experience in auditing contemporary and classical British literature more than 15 years. The other part of the literary works included audio texts recorded by short stories author, David Constantine, a British writer, poet and translator, English teacher at Oxford University, laureate of many literary awards, including the BBC's National Prize for the best stories, mainly for his short story "Tea in the Midland".

The choice for standard British pronunciation (Received Pronunciation) is due to the fact that this option is considered a kind of marker of high level intelligence and still prevails in the speech of the Royal family, members of parliament and the executive power of the country. Moreover, the British themselves associate Received Pronunciation with the prestigious professions and the well-known origin of the speaker.

The first group of the speakers consisted of five people with higher education and a scientific degree, representing the following professional groups: a lawyer, a diplomat, a doctor, an entrepreneur, a linguist, all of them having a high degree of English language proficiency. The second group included the speakers consisting of seven persons with incomplete higher education or higher education and intermediate level of English (an actress, a journalist, a freelancer, a translator, a student, a worker, a social services worker, a politician).

Mainly, the representatives of the third group, consisting of five people, have secondary education and low level of English (a nanny, a cosmetologist, a worker, a student, an athlete).

Such criteria were used based on the theory of social stratification by V. Labov, who emphasizes that gender, age, and social status of the speakers are considered to be the most important factors in the differentiation of pronunciation ${ }^{2}$. According to the analysis of the questionnaire data, all speakers were divided into three complex groups:

2 Лабов У. О механизме языковых изменений. Новое в лингвистике.: Прогресс, 1975. Вип. 7. С. 199-228. 
1) native English speakers, professional speakers who were born and reside in the United Kingdom, have standard English pronunciation (10\% of total speakers);

2) non-native English speakers, the speakers of Slovak origin, who were born and live in Slovakia (37\% of total speakers);

3) non-native English speakers, the speakers of Slovak origin, who were born in Slovakia, but emigrated to the United Kingdom and have lived there for a long period of time (from five to twenty-five years), whether working at companies or studying at universities, they speak and understand Slovak (53\% from the total number of speakers).

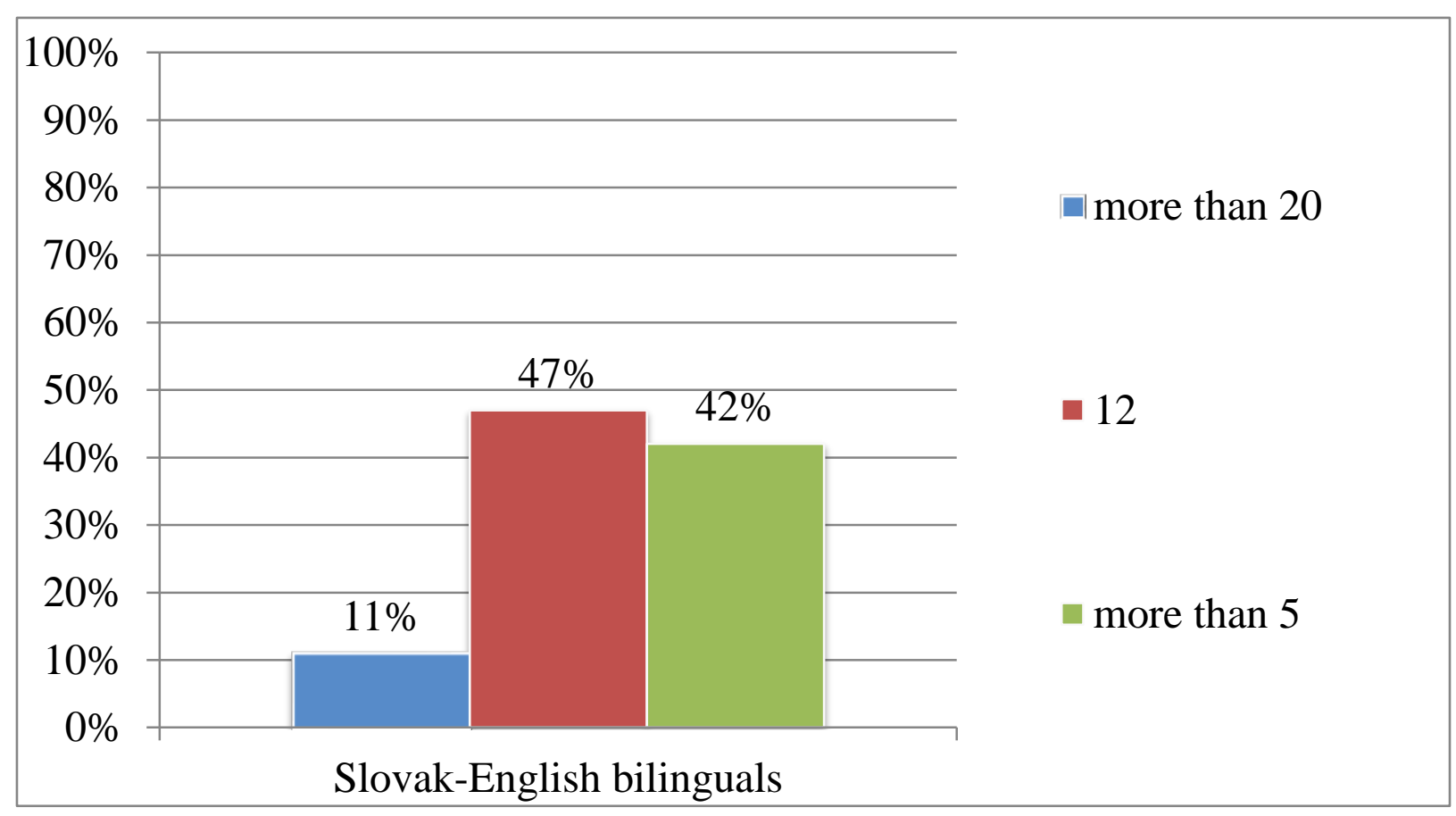

\section{Pic. 7. Residence duration of Slovak-English bilinguals in United Kingdom.}

A multiaged category of the Slovaks, including those living in the United Kingdom, was selected to achieve the goals and objectives of the experimental-phonetic study. Thus, the age of the Slovaks varies from 27 to 57 years, but the maximum number $(47 \%)$ is not more than 40 years.

The experimental material was recorded in two stages: the recording of literary texts narrated by native speakers of English, professional narrators and permanent residents of the United Kingdom, who have 
standard English pronunciation (first group of speakers); the recording of the main part of the experimental material with non-English speakers, the Slovaks by origin, who emigrated to the United Kingdom and lived there from five to twenty-five years (second, third and fourth groups).

Phonetic analysis of the suprasegmental level was performed according to the research methodology due to the following plan:

1) auditive analysis of narrated texts by auditors-informants, native speakers of the orthoepic norm of English, naive English users;

2) auditive analysis by English-speaking auditors, philological informants with experience in auditing narrated texts;

3 ) auditive analysis of perceptive characteristics of experimental texts by professional phoneticians;

4) acoustic analysis of the tonal, temporal and dynamic prosodic characteristics of the standard and interfered utterances.

The outcomes of the analysis, conducted by naïve user of English and professional phoneticians showed that a certain tonal, dynamic and temporal design ensures the actualization of standard and interfered statements with different degrees of phonetic interference, that is low, medium and high.

\section{CONCLUSIONS}

Auditive analysis conducted by both auditors without philological training, and with philological training, whose purpose was to establish the specificity of the English pronunciation of the Slovaks at a prosodic level allows to assert that a number of factors influence the actualization of English interfered utterances and makes possible the analysis interpretation of the data obtained.

Auditive analysis conducted by native speakers of English without philological training, allowed to establish the natural sound of the experimental material corpus and its compliance with the pronunciation standard of British English; standard and interfered statements; the accent of the speaker, the clarity of his pronunciation, the readability of the perceived text; the nationality of the speaker or his / her descent (native English speaker, of Slovak origin, other origin, etc.); the availability / lack 
of education (secondary, higher); social status of the speaker (student, volunteer, member of public organization, member of parliament, social worker, scientist, etc.); his / her affiliation with a particular professional group (foreign language specialist / non-specialist).

The results of the analysis showed that the clarity of the English pronunciation of the Slovaks and the comprehensibility of the text differed from their standard equivalent. The informant auditors found that the speakers with low level of phonetic interference were able to convey the emotional saturation and pragmatic purpose in all four narrated texts.

The English speech of the Slovaks with medium interference was qualified by the informants as not entirely clear, with some misspellings that sometimes affected the convey of emotional saturation and purpose. Besides, incorrect convey of the pragmatic potential of utterances was actualized by the speakers with high level of phonetic interference.

According to the data obtained during the analysis of informant auditors with philological training, there is reason to believe that a certain tonal, dynamic and temporal design ensures the actualization of standard and interfered statements with different degrees of interference.

\section{SUMMARY}

The study deals with the comprehensive study of prosodic characteristics of English Speech of the Slovaks and the identification of deviations from the pronunciation standard in the speaker's non-native speech.

On the basis of existing theoretical and experimental works on the study of English speech of the Slovaks, we have qualified it as an interfered English speech formed as a result of the interaction of phonetic systems of the English and Slovak languages. Moreover, the intercultural communication of Slovaks is a form of communication of the population of this region, in which the ways of realization of different situations by different cultures are not identical, that is, there are differences in their implementation and interpretation. The multi-ethnicity, multilingualism, multiculturalism and multimentality of the Slovak people, namely immigrants to United Kingdom is observed in the study. 
The experimental research outcomes have shown that a certain tonal, dynamic and temporal design ensures the actualization of standard and interfered statements with different degrees of interference.

\section{REFERENCES}

1. Лабов У.О механизме языковых изменений. Новое в лингвистике. Москва : Прогресс, 1975. Вип. 7. С. 199-228.

2. https://www.collinsdictionary.com/dictionary/english/receivedpronunciation

\section{Information about the author:}

Devitska A. I.,

Candidate of Philological Sciences, Associate Professor at the Department of Theory and Practice of Translation

Uzhhorod National University 45, office 503, Universytetska str., 88000, Uzhhorod, Zakarpattia region, Ukraine 


\section{VERBALIZATION OF POLITENESS IN MODERN ENGLISH}

\section{Fabian M. P.}

\section{INTRODUCTION}

The ability of human beings to talk - to use language in order to communicate with each other - is so universal and seems so natural that most of us do not think much about it. We take it for granted that it is normal for human beings to talk, the same as to eat, sleep or walk. Though it is true that every normal human being is able to use language, it is misleading to compare this with his/her ability to eat, sleep, or walk. All of these abilities are passed on to us by genetic transmission: we inherit them from our parents, but in the case of language it is only the ability to talk and understand that is inherited genetically. The language or languages we speak are passed on to us by cultural transmission, i.e. a language is something that we learn and are taught, not something that we know by instinct. By the statement that language is culturally transmitted we mean that it is part of the whole complex and shared behaviour which is called culture. The latter includes a shared background (for example, national, ethnic, religious) resulting from a common language and communication style, customs, beliefs, attitudes, and values ${ }^{1}$.

Culture, unlike language, is not composed of fixed rules that apply to all members of one culture. In its broad sense, culture has two major aspects: the history of civilization and a sociological component by which we mean the attitudes, customs, traditions, daily activities of people, their ways of thinking, their values, etc. Moreover, cultural patterns, customs and ways of life are generally reflected in the language because language and culture are mutually interdependent and mutually influential. Furthermore, without a strong power - base, whether political, military or economic, no language can make progress as an international medium of communication. Language has no independent existence, living in some

\footnotetext{
${ }^{1}$ Levine D.R., Adelman M.B. Beyond Language. Cross-Cultural Communication. New Jersey: Prentice Hall, 1993. P. 2. 
sort of mystical space apart from the people who speak it. Language exists only in the brains and mouths and ears and hands and eyes of its users. When they succeed, on the international stage, their language succeeds. When they fail, their language fails ${ }^{2}$.

Human language is a universal and recognizable part of human behaviour and of the human faculties, perhaps one of the most essential to human life, and one of the most far - reaching of human capabilities in relation to the whole span of mankind's achievements. Language in all its forms and manifestations constitutes the field of the linguist. He seeks a scientific understanding of the place of language in human life, and of the ways in which it is organized to fulfil the needs it serves and the functions it performs ${ }^{3}$.

Etiquette lexis functions and develops in close relationship with the society. Norms of etiquette reveal the state of the society's cultural development, and following them contributes to its progress. This is a dialectical unity and connection between etiquette and society.

\section{Language and culture relationship}

Meaning in language involves a set of multiple and various relations holding between the utterance and its parts and the relevant features and components of the environment, both cultural and physical, and forming part of the more extensive system of interpersonal relations involved in the existence of human societies. The term culture is widely used in a number of different ways. It is taken from the technical vocabulary of anthropology, wherein it encompasses the entire way of life of community members in so far as it is conditioned by that membership. Culture refers to the patterns of human activity and the symbols that give significance to these activities. It manifests itself in terms of the art, literature, costumes, customs, language, religion and religious rituals. The people and their patterns of life make up the culture of a region. Cultures vary in the

${ }^{2}$ Crystal D. English as a global language. Cambridge: Cambridge University Press, 1997. P. 5.

${ }^{3}$ Robins R.H. General Linguistics. An Introductory Survey. London: Longmans, 1967. P. 2-3. 
different parts of the world. They differ across boundaries and the diversity of cultures results in the diversity of people around the world.

Culture is the centre of a society, and without it no society can exist. It is a heritage transmitted from one generation to another; it includes all the ways and behaviours of social life; no culture belongs to an individual, and it does not exist in isolation because it is a product of society, and develops through social interaction. Modern times have witnessed an intermix of cultures. The latter are blended together giving rise to shared cultures. By culture we mean: 1) the arts and other manifestations of human intellectual achievement regarded collectively; 2) the ideas, customs, and social behaviour of a particular people or society. Wikipedia defines culture as an umbrella term which encompasses the social behaviour and norms found in human societies, as well as the knowledge, beliefs, arts, laws, customs, capabilities and habits of the individuals in these groups. It has the following characteristics:

- culture is learned and acquired;

- culture is shared and transmitted;

- culture is social;

- culture is ideational;

- culture gratifies human needs;

- culture is adaptive;

- culture tends toward integration;

- culture is cumulative.

The word "culture" means language, communication, courtesies, rituals, roles, customs, relationships, practices, expected behaviours, values, thoughts and manners of interacting. Furthermore, culture includes medical care, religion, food, folk art, celebrations, jokes, manners, clothes and dressing, working schedules, child-rearing methods. The relationship between language and culture is deeply rooted. Language is used to maintain and convey culture and cultural ties. Learning about culture is just as important as learning the languages. To fully appreciate a language, we need to understand the culture of the people who speak it. Language is the method of human communication, either in written or a spoken form whereas, culture is the idea, values and beliefs we have in our society. 
Communication or language is a mechanism for channeling culture and cultural bonds that reflects and reproduces culture. Different ideas are born form different languages within the same culture. Culture is something influenced and impacted by the language whereas, language is formed by the culture of a society. Similarly, language is not only an expression or a means of communication, but a component of a culture that makes it unique and specific. The implications of the link between language and culture is very important to understand the values, ideologies and history. We must be able to understand the cultural background of language to truly learn the language.

Language and culture are intimately related. They change together. We pass on our culture through our language, and we are guided by our language to determine our culture. Our culture and our language to some extent determine possible changes in both. Language and culture are systems that reinforce each other and exclude something of which they cannot conceive because their language does not allow them to think of those things or of which their culture does not contain.

The exact nature of the relationship between language and culture has fascinated, and continues to fascinate, people from a wide variety of backgrounds. One long-standing claim concerning the problem in question is that the structure of a language determines the way in which speakers of that language view the world. A somewhat weaker version is that the structure does not determine the worldview but is still extremely influential in predisposing speakers of a language toward adopting a particular worldview. The opposite claim would be that the culture of people finds its reflection in the language they employ, i.e. they value certain things and do them in a certain way, so they use their language to reflect what they value and what they do. In this view, cultural requirements do not determine the structure of a language, but they influence the ways a language is used. Finally, there also exists a viewpoint based on the assumption that there is little or no relationship between language and culture. Acknowledging close relationship between language and culture, we consider that any overestimation/underestimation either of a language or a culture can cause misunderstandings and lead to inadequate conclusions. 
Language learning should be tied up with culture learning, but it does not mean that one cannot exist without the other. With language learning, we do not just learn about the language: we learn to speak it. With culture learning, we do not just learn about a culture: we learn how to cope with cultural differences, and we learn how to effectively communicate with people in another culture. Learning to communicate comfortably with people is as important as learning the rules of a language. Moreover, language learning and culture learning go together and may take a long time. Much of human experience - both individual and corporate - is mediated through communication, linguistic as well as non-linguistic. A good way to become aware of interaction in another culture is to think about how we interact with people in our own language and culture. This helps recognize both differences and similarities between our and another cultures. Language itself is the most remarkable tool that man has invented, and is the one that makes all the others possible. Language, in fact, is the great machine tool which makes human culture possible ${ }^{4}$.

In the language development the social nature of lexical units is revealed in a variety of forms. Moreover, the ongoing processes of change affect all aspects of English structure. As always, the most noticeable sign of change is in vocabulary, which reflects the multiple social, scientific, technological, and economic developments. During the later decades of the XVII century the proliferation of tea terminology began to enter English vocabulary. As Crystal David puts it, the first recorded reference to the word is 1655. In 1661, tea-taking was introduced into the Restoration Court by Queen Catherine, the Portuguese wife of Charles II, and it immediately became the fashion. At high social levels, it became a formal ritual accompanied by an elegant apparatus of silver spoons, pots, stands, tongs, and caddies, and an occasion for polite conversation. But the innovation was taken up by other levels of society, too. As its price fell, everyone adopted the habit, upstairs and downstairs alike, taking tea usually twice a day ${ }^{5}$. In an era where much emphasis is laid on social hierarchy, degrees in society become very important. It is the time when a

\footnotetext{
${ }^{4}$ Barber C.L. The Story of Language. London: Pan Books Ltd., 1972. P. 1.

${ }^{5}$ Crystal D. The Stories of English. Woodstock \& New York: The Overlook Press, 2004. P. 370.
} 
special attention is paid to codes of appearance, hair-style, all aspects of behaviour, and especially language. The words like polish, refinement, manners, politeness, elegant, respect, courtesy, tact, compliment, attention, civility and many others characterize both everyday lives of people and various ways as well as forms of performing their everyday communications.

It is possible to treat politeness as a fixed concept, as in the idea of "polite social behavior", or etiquette, within a culture. It is also possible to specify a number of different general principles for being polite in social interaction within a particular culture. Some of these might include being tactful, generous, modest, and sympathetic toward others ${ }^{6}$.

Good manners, polite behaviour and reverential attitude, respect towards people irrespective of their age, sex, cultural and educational background are highly evaluated in the society. In other words, all the abovementioned qualities and characteristics refer to etiquette which denotes: 1. a. The prescribed ceremonial of a court; the formalities required by usage in diplomatic intercourse. $b$. The order of procedure established by custom in the army or navy (esp. with reference to promotion), in parliament, etc. c. The conventional rules of personal behaviour observed in the intercourse of polite society; the ceremonial observances prescribed by such rules. $d$. The unwritten code of honour by which members of certain professions (esp. the medical and legal) are prohibited from doing certain things deemed likely to injure the interests of their brethren, or to lower the dignity of the profession. 2. A rule of etiquette; an observance prescribed by etiquette. 3. In the primary Fr. sense: a label ${ }^{7}$. Etiquette in Webster's New Encyclopedic Dictionary is explained as: the body of rules governing the way in which people behave socially, ceremonially, or in public life [French étiquette, literally, "ticket"]. Origin. The primary meaning of French etiquette is "ticket, label attached to something for description or identification". It was once the practice in royal palaces of France to post notices that set down the proper forms to be observed at court. Such notices were called étiquettes. The word came to be used for

\footnotetext{
${ }^{6}$ Yule G. Pragmatics. Oxford: Oxford University Press, 1996. P. 60.

${ }^{7}$ The Compact Edition of the Oxford English Dictionary in 2 volumes. Complete Text Reproduced Micrographically. Oxford: Oxford University Press, 1971.
} 
the court ceremonial itself as well as the document that described it. It was this sense of French étiquette that English borrowed ${ }^{8}$. Etiquette is also defined as the set of rules or customs which control accepted behavior in particular social groups or social situations ${ }^{9}$. Longman Dictionary of English Language and Culture explains the meaning of the word in question the following way: the formal rules of proper (social) behaviour: medical/professional etiquette. Cultural Note. In Britain, the rules of social behaviour are not as severe as they were in the past, but there are still many rules about formal behaviour in upper-class society. People who move up in society sometimes look at etiquette books to learn how they are expected to behave $\mathrm{e}^{10}$. Despite minor differences, the abovementioned dictionaries as well as other theoretical sources highlight the essence of etiquette as a set of rules for behaving correctly in social situations, and also rules about behaviour for people in a particular profession.

\section{Lexical semantic analysis of the nouns denoting politeness in modern English}

Majority of words denoting politeness in modern English are polysemantic. They make up a system of elements which reveals various language means of expressing the notion of politeness. All the meanings of the nouns in question are interconnected and interrelated. To collect and analyze them, the methodology of formalized analysis of lexical semantics is used ${ }^{11}$. To choose the material of our research and study the system and structural peculiarities of its lexical semantics, a formal, pure linguistic criterion is introduced - belonging of the words to a definite part of speech. In our study it is the noun. It means that the lexical units refer to a definite class in English whatever semantic functions other members of that class may fulfil, and the label noun is applied to all the words assigned to this

\footnotetext{
${ }^{8}$ Webster's New Encyclopedic Dictionary. Cologne, Germany:Könemann, 1993. P. 344.

${ }^{9}$ Cambridge International Dictionary of English. Cambridge:Cambridge University Press, 1995. P. 470.

${ }^{10}$ Longman Dictionary of English Language and Culture. England: Longman Group UK Limited, 1992. P. 436.

${ }^{11}$ Фабіан М.П. Семантика мовного етикету: новий підхід до ії вивчення // Сучасні дослідження з іноземної філології, випуск 12. Ужгород : ПП “Аутдор -Шарк”, 2014. C. 7-13.
} 
class. This means that some words in many languages, especially words in frequent use, have to be classified under more than one head ${ }^{12}$. Our word class is open in membership, i.e. its membership is unlimited, varying from time to time and between one speaker or another. The language material under analysis is selected from the explanatory dictionary of English ${ }^{13}$ owing to the way the lexical units are presented in it. In this case we mean that each word in the explanatory dictionary appears as a linguistic fact possessing a certain form and content. Its form is treated as a manifold phenomenon, owing to which the lexical meaning can be revealed in its entirety. The correlation between form and content in modern linguistics is best revealed in the dictionaries: the completest the dictionary, the most detailed this correlation description seems to be. The explanatory dictionary helps make the analysis of the words by linguistic means. Furthermore, explanatory dictionaries provide an exhaustive information concerning language units. Each definition of the word in the dictionary entry presents one of the meanings of this word.

Lexicographical representation of any separate meaning has a complex inner structure. For this reason, in every definition of the nouns denoting politeness we look for the properties and other characteristics which correspond to elementary notions. In the process of our linguistic analysis, the binomial feature of the noun's semantic definition should be taken into consideration: the left part is a word or phrase which needs to be defined, and the right part contains a word, phrases, often lines of phrases to define the meaning of a headword. Moreover, these components reflect one and the same class of subjects, but along with the relations of equality in the semantic definition, there also exit the relations of inequality ${ }^{14}$.

The lexis under study in modern English is characterized by two interconnected facets: the system of nouns as signs to describe their meanings and the system of semantic shades of meaning attached to the nouns. In this respect, each semantic definition to this or that extent fixes

\footnotetext{
${ }^{12}$ Robins R.H. General Linguistics. An Introductory Survey. London:Longmans, 1964. P. 229.

${ }^{13}$ The Oxford English Dictionary: In 12 volumes. London: Oxford University Press, 1961.

${ }^{14}$ Арбатский Д.И. Семантические определения (основные проблемы толкования значений слов): дис. ... докт. филол. наук: 10.02.01. Ижевск, 1981. С. 31.
} 
these two facets. While analyzing dictionary definitions to describe the meanings of the nouns denoting politeness, we stick to the point that the dictionary definition is a metalanguage category which is realized in one and two component forms. By the first the definition consisting only of the nucleus is meant, whereas the second means that the definition is composed of the nucleus and its synonymic equivalents, owing to which the broadening of semantic range of the lexical unit takes place, because they help the latter to enter different lexical microsystems. For the allround study of the words' semantics, of great importance is the way the meanings of words are interpreted by means of other words' meanings in the same dictionary. Not always the dictionary definition suggests an exact equivalent of the necessary word. If the word is used in its figurative meaning, it is to be studied the same way as a main vocabulary one. For the most adequate description of lexical units, the words are used which exactly correspond to the notion under study. We name such words as dominants of the synonymic lines. Not all the elements of the lines become dominants: semantics of the nouns is not limited by the variation of one narrow notion; they also contain other content characteristics. To analyze our English language material, the dominants' meanings are decomposed into components.

It explains the fact why in the process of studying the relationships between the nouns denoting politeness as well as their places and roles, the explanatory dictionary of English serves as the main source of our language material. As a result, we obtained a group of nouns, semantics of which describes various ways of expressing politeness which is closely connected with etiquette, and, to be more exact, makes a part of the latter.

On the whole, Crystal D. compares words with children: we need to know how to look after them and when to let them look after themselves; when to be proud of them, and when to be worried about them. To do all that, we need to find out as much as we can about them. We need to know how words change their meanings and uses, and why. We need to understand the communicative properties of words, so that we can exploit them to our advantage. Above all, we need to be able to describe, 
comprehensively and objectively, the universe of words, and the way people live in it. In short, we need to become lexicologists ${ }^{15}$.

Before making lexical semantic analysis of the nouns in modern English, we have in short to introduce the notion of politeness, and then disclose its relations with other words in the system of the language.

The central notion of etiquette is politeness which presupposes polished manners, courtesy, mental or intellectual culture: polish, refinement, elegance, good taste, deference, tact, and the like. A social historian, Vickery A., writes about the significance of politeness: "Politeness in the eighteenth century meant much more than mere etiquette, and minding your ps and qs. It was an all-embracing philosophy of life, and a model for a harmonious society. It promoted openness and accessibility in social behavior, but at the same time set strict standards of decorum for merchants and manufacturers to live up to. Politeness demanded that people should make themselves agreeable to others, to give pleasure as well as take it. Indeed the social lubrication which politeness offered was one of its great attractions, because it offered a way for very different sorts of people to get along without violence, and helped heal the wounds of civil war. Politeness was an intellectual response to the uncompromising religious fanaticism of the civil war years, and the political hatreds which lingered afterwards"

Politeness stands in line with manners and morals. The latter are never neutral. Their usefulness to men and women lies in this fact for implicit in manners and morals are attitudinal appraisals. Attitudes have their origins in what is termed general or encyclopaedic knowledge of the world and how this knowledge is viewed in terms of the cultural values of a community ${ }^{17}$. Verbalization of politeness in its various aspects in modern English is represented by the nouns manners, respect, courtesy, culture, elegance, grace, attention, ceremony, tact, compliment, civility and civilities.

\footnotetext{
${ }^{15}$ Crystal D. Words. Words. Words. New York: Oxford University Press, 2006. P. 6.

${ }^{16}$ Vickery A. In Pursuit of Pleasure. Milton Keynes: Open University Press, 2001. P. 156.

${ }^{17}$ Chitra F. Idioms and Idiomaticity. New York: Oxford University Press, 1996. P. 139.
} 
The Oxford English Dictionary defines the lexical unit respect as: I. In phrases (usually) without article. II. An aspect of a thing, a relative property or quality, a relationship of one person or thing to another; reference to some thing or person, regard, consideration. III. Appearance, aspect; discrimination, partiality, or favour in regard of persons or things. Heed, care, attention. IV. Deferential regard or esteem felt or shown towards a person or thing. The condition or state of being esteemed or honoured. Rank, standing, station in life. pl. Deferential or courteous attentions; actions expressive of respect for a person; politenesses, courtesies. Deferential salutations. In complimentary formula, usually conveying a message expressive of regard or esteem. To pay one's respects, to show polite attention to a person by presenting oneself or by making a call.

The lexical unit culture denotes: 1. Worship; reverential homage. 2. The action or practice of cultivating the soil; tillage, husbandry. b. Cultivated condition. c. A piece of tilled land; a cultivated field. 3 . The cultivating or rearing of a plant or crop. b. The rearing or raising of certain animals, such as fish, oysters, bees, etc., or of natural products such as silk. c. The artificial development of microscopic organisms, esp. bacteria, in specially prepared media; the product of such culture; a growth or crop of artificially developed bacteria, etc. d. The training of the human body. 4. The cultivating or development (of the mind, faculties, manners, etc.), improvement or refinement by education and training. 5. The training, development, and refinement of mind, tastes, and manners; the condition of being thus trained and refined; the intellectual side of civilization. b. (with a and pl.) A particular form or type of intellectual development. 6. The prosecution with special attention or study of any subject or pursuit.

The noun manners, in its turn, means: a) polite ways of behaving in social situations, and b) the customs of a particular group of people. Attention also belongs to the group of words under study. It is characterized by broad semantics, because its meanings show various ways of their implications: 1. The action, fact, or state of attending or giving heed; earnest direction of the mind, consideration, or regard; esp. in phr. to give or pay attention. The mental power or faculty of attending; esp. with 
attract, call, draw, arrest, fix, etc. 2. Practical consideration, observant care, notice. 3. The action of attending to the comfort and pleasure of others; ceremonious politeness, courtesy. 4. A matter of attention, a consideration. 5. A cautionary word used as a preparative to any particular exercise or manoeuvre. Close to the word in question stands the noun tact which describes the ability to be polite and careful about what you say or do so that you do not upset or embarrass other people.

In the process of our language material analysis, it becomes evident that the lexical units as the components of the system and structure of English are described in the dictionary with the help of diversiform repetitions of one and the same properties to a lesser or greater extent. This repetition forms a variety of lexical semantics' structural organization continuity. The latter is represented by definitions which, if compared, show that the lexical meanings of the nouns denoting politeness in English come open according to the principle of explaining one word through the second, the second through the third, and so on. As a result, in defining the semantics of the word in its direct connection with the other or other lexical units, we establish, by comparing their semantic structures, not only the presence (absence) of common semantic components, but also the degree of their manifestation. This chain correlation constitutes the semantic regularity of politeness lexis formation.

The quantitative growth of the lexical units under study in the dictionary of modern English occurs against the background of qualitative shifts throughout the vocabulary. It is displayed in the rise of the words' abilities to more exactly express thoughts and emotions of people living in the definite society. Moreover, the research of politeness lexis is directly dependent on the study of the person's inner world which includes imagination, memory, dreams, emotions, evaluation, etc. The process of human cognition always contains the element of evaluation because a man in perceiving the surrounding reality does not remain a passive observer, but expresses his interest in it. The latter inevitably leads to the evaluative classification of the environment and oneself. Evaluation is necessarily present when there is a contact between the subject and the objective world $^{18}$.

${ }^{18}$ Приходько Г.І. Оцінка і комунікація. Вінниця: Нова Книга, 2013. С. 22. 
Evaluative aspect plays an important role in the interaction of a man with the world. In the process of human cognition, upbringing, education, everyday life of a person, his/her character, tastes, outlook produce a certain value system in the individual, based on which he/she gives assessment of the whole world. Evaluation belongs to the number of human categories. It is set by physical and psychic nature of man, his/her being and feeling, it sets thinking and activity, his/her perception of arts ${ }^{19}$. The group of nouns denoting politeness describes various ways and means of expressing evaluation. For example, the lexical unit compliment possesses the following characteristics of showing formal respects: 1. A ceremonial act or expression as a tribute of courtesy, "usually understood to mean less than it declares", now, esp. a neatly - turned remark addressed to any one, implying or involving praise; but, also applied to a polite expression of praise or recommendation in speaking of a person, or to any act taken as equivalent thereto. b. (without a or pl.) Complimentary language; polite expression of praise or flattery. 2. Usually in pl. Formal respects, remembrances, greetings; esp. in phrases. 3. A complimentary gift, a present, gratuity.

The lexical unit grace expresses: 1. A smooth controlled way of moving that is attractive to look at, esp. because it seems natural and relaxed. 2. a) polite and pleasant behaviour; b) graces - the skills needed to behave in a way that is considered polite and socially acceptable: social graces. 3. More time that is added to the period you are allowed for finishing a piece of work, paying a debt, etc. 4. God's kindness shown to people because he loves them. 5. A prayer thanking God, said before a meal. 6. The state of someone's soul when it has been freed from evil, according to Christian belief. Politeness is concerned not only with refined manners, but also courteous behaviour and formal acts expressive of deference or respect. Such meanings explain semantics of the nouns courtesy, ceremony and elegance. The words under analysis in the dictionary of English possess the following characteristics: courtesy 1. Courteous behaviour; courtly elegance and politeness of manners;

${ }^{19}$ Приходько Г.І. Категорія оцінки в контексті зміни лінгвістичних парадигм. Запоріжжя:ЗНУ, 2015. С. 34. 
graceful politeness or considerateness in intercourse with others. 2. As a quality: courteous disposition, courteousness; also nobleness, generosity, benevolence, goodness. 3. Courteous title: a title of no legal validity given by social custom or courtesy; esp. applied to the territorial titles given to the eldest sons of earls and peers of higher rank, the prefix Lord or Lady to the names of the younger sons and the daughters of dukes and marquises, and of Honourable to the children of Viscounts and Barons. 4. Law. A tenure by which a husband, after his wife's death, holds certain kinds of property which she has inherited, the conditions varying with the nature of the property. 5. (pl.) A courteous act or expression. 6. The courteous or ceremonious expression of apology or deprecation. 7. The customary expression of respect by action or gesture, esp. to a superior; the action of inclining, bowing, or lowering the body, usually, in phr. to make or do courtesy. 8. An obeisance. 9. A "mannerly" or moderate quantity. 10. Used like worship, etc. as an ascriptive title.

The next word under analysis is ceremony which means: 1. An outward rite or observance, religious or held sacred; the performance of some solemn act according to prescribed form; a solemnity. b. A rite or observance regarded as merely formal or external; an empty form. Sometimes regarded as symbolic or typical. c. Applied to a thing done in a formal or ceremonious way; a stately formality. 2. A formal act or observance, expressive of deference or respect to superiors in rank, or established by custom in social intercourse; a usage of courtesy, politeness, or civility. 3. (without a or pl.) Formal observances or usages collectively, or as an order of things: a. in reference to matters of religion or state: Performance of rites, ceremonial observance. b. Precise observance of conventional forms of deference or respect; formality, ceremoniousness. c. Ceremonious respect or regard. d. Ceremonial display, pomp, state. 4. An external accessory or symbolical "attribute" of worship, state, or pomp. 5. A portent, omen (drawn from the performance of some rite). 6. Master of the ceremonies: the person who superintends the ceremonies observed in a place of state or on some public occasion. By elegance we mean: 1. Refined grace of form and movement, tastefulness of adornment, refined luxury. 2. Of spoken or written compositions, literary style: Tasteful correctness, harmonious simplicity, 
correctness, harmonious simplicity, in the choice and arrangement of words. 3. A. Of scientific processes, demonstrations, inventions: Neatness, ingenious simplicity, convenience, and affectiveness; so of a prescription, etc. b. Roman Law. 4. a. Correctness of taste. b. Of manners: Refined propriety. 5. Something which is elegant, a particular instance or kind of elegance. Polite behaviour which most people consider normal is called civility. Formal word civilities is something that you say or do in order to be polite. Semantic structures of the nouns expressing politeness are represented as the complexes of interconnected separate meanings within the polysemantic words. Forms, like meanings, are culturally determined. They are also distributed in patterned ways. Forms are relevant when they possess meanings; meanings presuppose forms in order to be of relevance to us, and meaningful forms always occur in patterned distribution ${ }^{20}$.

The use of dictionaries helps define the word's semantic structure as an element of the language's lexical system. Lexical semantic analysis of the words in question shows that within the politeness lexis the word is characterized by the clear - cut hierarchical structure, and the degree of the word's independence in it as well as the sphere of its everyday usage depend upon the character of the relations between the words and the notions they denote, role and place the semantic elements of the words occupy in the system of lexis.

In modern linguistics there exist three viewpoints concerning structural organization of a polysemantic word content:

1) in the structural organization of a polysemantic word's semantics, there is a hierarchy; separate meanings of such words are unequal;

2) the meanings of a polysemantic word are equal, and there is no division into main - secondary, direct - figurative and so on;

3 ) in some cases, the meanings of a polysemantic word are equal, and in others - unequal $^{21}$.

${ }^{20}$ Fabian M. Etiquette Behaviour in the Context of Language and Culture Learning мові// Сучасні дослідження з іноземної філології, випуск 7. Ужгород :ТОВ “ПапірусФ", 2009. С. 6.

${ }^{21}$ Левицкий В.В. Экспериментальные данные к проблеме смысловой структуры слова//Семантическая структура слова. Психолингвистические исследования. Москва: Наука, 1971. С. 153. 
The nouns denoting politeness in modern English form the set which consists of elements. The latter, though united by common properties, still possess certain autonomous peculiarities. In the definitions of polysemantic words one can observe relations which are characteristic of separate lexical units as the elements of the semantic system of English. One of the most important features of system relations in lexical semantics of English is their polyfunctionalism, i.e. between two elements of the language's semantic system, system relations perform the functions of microsystem or macrosystem character. Within the whole lexical system, qualitative different features of the word serve, on the one hand, as the means of lexical meaning formation, and, on the other, as peculiar clips, on the basis of which this lexical meaning of politeness joins the semantic system of English as its element. The presence of such polyfunctional relations characterizes another semantic regularity of politeness lexis formation. Furthermore, the changes in the relations between the words as well as the relations between the meanings within the word, are connected with the changes in the semantic structure of English in general ${ }^{22}$. A detailed and all - round study of each word's specificity helps reveal the peculiarities of its semantics and generalize politeness lexis theory in modern English.

To conclude, within the group of nouns denoting politeness in modern English, the words by means of their meanings are closely interconnected, and thus form the chains of direct as well as indirect ties. Moreover, each element of this group possesses its peculiar individual meanings, owing to which politeness semantics intersects with the concrete semantics of the nouns under study.

\section{CONCLUSIONS}

Contemporary linguistics regards language as a social activity rather than as a means of individual self-expression. Language we speak not only brings human beings into relationship with each other, but it also brings them into relationship with the external world. Language mediates between man and his environment. It is one of the most powerful emblems of social

22 Фабіан М.П. Семантична структура багатозначних лексичних одиниць на позначення етикету в сучасній англійській мові// Сучасні дослідження 3 іноземної філології, випуск 8. Ужгород : ПП “Аутдор -Шарк”, 2010. С. 7. 
behaviour. In the normal transfer of information through language, we use it to send vital social messages about who we are, where we come from, and who we associate with. Consequently, language use symbolically represents fundamental dimensions of both social behaviour and human interaction. There is a correlation between the form and content of a language, and the beliefs, values and needs embedded in the culture of its speakers. Furthermore, the vocabulary of English supplies us with a catalogue of those things which might be important and necessary for the society, an index to the way speakers categorize experience, a record of contacts and cultural borrowings, etc. Moreover, English is much more than external expression and communication of internal thoughts formulated independently of their verbalization. It is a part of culture which refers to all aspects of human life insofar as they are determined or conditioned by membership in a society. Culture covers a very wide area of human life and behaviour, and language is manifestly a part, probably the most important part, of it.

Politeness in modern English is represented by the lexical units, semantics of which contains the indications of polite behaviour, manners, courtesy, polite attention, etc. To such words in our research belong the nouns manners, respect, courtesy, culture, elegance, grace, attention, ceremony, compliment, tact, civility and civilities. Each of them, besides indicating the notion in question, is characterized by its specific meanings which, for instance, denote an aspect of a thing, a relative property or quality, a relationship of one person or thing to another; reference to some thing or person, regard, consideration. Appearance, aspect; discrimination, partiality, or favour in regard of persons or things. Heed, care, attention. Deferential regard or esteem felt or shown towards a person or thing. The condition or state of being esteemed or honoured. Rank, standing, station in life (respect), God's kindness shown to people because he loves them. A prayer thanking God, said before a meal. The state of someone's soul when it has been freed from evil, according to Christian belief (grace), the action, fact, or state of attending or giving heed; earnest direction of the mind, consideration, or regard; esp. in phr. to give or pay attention. The mental power or faculty of attending; esp. with attract, call, draw, arrest, 
fix, etc. Practical consideration, observant care, notice (attention) and many others. All the nouns denoting politeness as well as their meanings form a definite set which possesses a structure. The latter is composed of elements united by common properties, but possessing their individual peculiarities. Both the nouns under study and their meanings, within politeness lexis, establish close relationships with other groups of the lexical system of modern English.

\section{SUMMARY}

The present research deals with the verbalization of politeness in modern English. The author discusses the topical issues of contemporary linguistics concerning the relationship between language and culture, their distinctive features, functions, role and place in both society and people's everyday activities. Much attention is paid to the lexical semantic analysis of the nouns denoting politeness in the vocabulary of English, peculiarities of their system and structural organization, different types of connections between the lexical units which are interrelated though characterized by their specific semantics. Politeness in the present research is represented as the central notion of etiquette which presupposes polished manners, courtesy, mental or intellectual culture: polish, refinement, elegance, good taste, deference, tact, and the like. The quantitative growth of the lexical units under study in the dictionary of modern English occurs against the background of qualitative shifts throughout the vocabulary. It is displayed in the rise of the words' abilities to more exactly express thoughts and emotions of people living in the definite society. Moreover, the research of politeness lexis is directly dependent on the study of the person's inner world which includes imagination, memory, dreams, emotions, evaluation, etc. The paper focuses on the use of dictionaries which help define the word's semantic structure as an element of the language's lexical system. Lexical semantic analysis of the words in our language material shows that within the politeness lexis the word is characterized by the clear - cut hierarchical structure, and the degree of the word's independence in it as well as the sphere of its everyday usage depends upon the character of the relations between the words and the notions they denote, role and place the semantic elements of the words occupy in the system of English lexis. The 
complex study of politeness verbalization in modern English helps recognize both differences and similarities between our and another cultures, enrich our life experience and improve all possible cross-language and cross-cultural communications.

\section{REFERENCES}

1. Barber C.L. The Story of Language. London: Pan Books Ltd., 1972. $294 \mathrm{p}$.

2. Chitra F. Idioms and Idiomaticity. New York: Oxford University Press, 1996. 265 p.

3.Crystal D. English as a global language. Cambridge: Cambridge University Press, 1997. $150 \mathrm{p}$.

4. Crystal D. The Stories of English. Woodstock \& New York: The Overlook Press, 2004. 584 p.

5. Crystal D. Words. Words. Words. New York: Oxford University Press, 2006. 216 p.

6. Fabian M. Etiquette Behaviour in the Context of Language and Culture Learning // Сучасні дослідження 3 іноземної філології, випуск 7. Ужгород :ТОВ “Папірус-Ф”, 2009. С. 5-9.

7.Levine D.R., Adelman M.B. Beyond Language. Cross-Cultural Communication. New Jersey: Prentice Hall, 1993. 286 p.

8. Robins R.H. General Linguistics. An Introductory Survey. London:Longmans, 1964. 391 p.

9.Robins R.H. General Linguistics. An Introductory Survey. London: Longmans, 1967. 398 p.

10. Vickery A. In Pursuit of Pleasure. Milton Keynes: Open University Press, 2001. 269 p.

11. Yule G. Pragmatics. Oxford: Oxford University Press, 1996. 138 p.

12. Арбатский Д.И. Семантические определения (основные проблемы толкования значений слов): дис. ... докт. филол. наук: 10.02.01. Ижевск, 1981. 305 с.

13. Левицкий В.В. Экспериментальные данные к проблеме смысловой структуры слова // Семантическая структура слова. Психолингвистические исследования. Москва: Наука, 1971. С. 151-168. 
14. Приходько Г.І. Оцінка і комунікація. Вінниця: Нова Книга, 2013. $168 \mathrm{c}$.

15. Приходько Г.І. Категорія оцінки в контексті зміни лінгвістичних парадигм. Запоріжжя: ЗНУ, 2015. 172с.

16. Фабіан М.П. Семантична структура багатозначних лексичних одиниць на позначення етикету в сучасній англійській мові // Сучасні дослідження 3 іноземної філології, випуск 8. Ужгород : ПП “Аутдор-Шарк”, 2010. С. 5-11.

17. Фабіан М.П. Семантика мовного етикету: новий підхід до іiі вивчення//Сучасні дослідження 3 іноземної філології, випуск 12. Ужгород : ПП “Аутдор -Шарк”, 2014. С. 7-13.

\section{IEXICOGRAPHICAL SOURCES}

18. Cambridge International Dictionary of English. Cambridge: Cambridge University Press, 1995.

19.The Compact Edition of the Oxford English Dictionary in 2 volumes. Complete Text Reproduced Micrographically. Oxford: Oxford University Press, 1971.

20. Longman Dictionary of English Language and Culture. England: Longman Group UK Limited, 1992.

21. The Oxford English Dictionary: In 12 volumes. London: Oxford University Press, 1961.

22.Webster's New Encyclopedic Dictionary. Cologne, Germany: Könemann, 1993.

\section{Information about the author: Fabian M. P.,}

Doctor of Philological Sciences in General Linguistics, Professor, Professor at English Philology Department Uzhhorod National University 14, office 521, Universytetska str., 88000, Uzhhorod, Zakarpattia region, Ukraine 


\section{SEMANTIC BASIS OF ENGLISH AND UKRAINIAN ASTRONOMY TERMS}

\section{Rohach L.V.}

\section{INTRODUCTION}

In modern linguistics the study of languages in contrastive aspect provides understanding the laws of development of human language, "being the most important means of formation and existence of human knowledge of objective reality" ${ }^{\text {. Contrastive investigation of languages }}$ proved to be extremely captivating as far as "different languages are not different designations of the same subject, but different visions of it" .

Considering rapid development of science and technology in contemporary world, it becomes quite obvious that the problems of contrastive studies of terminological systems of different languages are becoming increasingly relevant both in theoretical and applied aspects. The investigation of structural-semantic peculiarities of terminologies of different language systems appears especially valuable in this respect. The research of the mechanism of transformation of a common language meaning into terminological is a scientific task, the essence of which lies in the analysis of deep processes, that are going on in the semantic structure of a word. From the point of view of relationship between the level of development of terminological systems and scientific and technical progress, linguists quite naturally concentrate their attention on the linguistic background of already existing terminological systems.

In the present paper the main semantic features of English and Ukrainian terms of astronomy as both elements of common language system and words in special function denoting scientific notions are investigated. The scientific relevance of the research is predetermined by

\footnotetext{
${ }^{1}$ Фабіан М.П. Етикетна лексика в українській, англійській та угорській мовах. Ужгород: Інформаційно-видавниче агентство “ІВА”, 1998. - С. 7-8.

${ }^{2}$ Гумбольдт Вильгельм фон. Избранные труды по языкознанию. Пер. с нем. - М.: Прогрес, 1984. - С. 9. 
application of methodology of formalized analysis of lexical units' semantics $^{3}$ aimed at studying semantic peculiarities of astronomy terms in English and Ukrainian. This methodology enabled us to construct matrices of semantic space of the English and Ukrainian terms of astronomy. In the present research matrix description of terminological systems gives the possibility of 1) defining the place of English and Ukrainian terms of astronomy in common language; 2) presenting the structure of their semantics; 3) identifying the connection of astronomical terms of both languages with other terminological units; 4) comparing the semantic space of terminology under study in English and Ukrainian.

In our research we analyze 197 English and Ukrainian terms of astronomy selected from terminological lexicographical sources. The common language meanings of the lexical units are analyzed on the basis of explanatory dictionaries. Applying method of componential analysis, we selected components of meanings from special and common language meanings of lexical units and constructed two matrices designating semantic space of English and Ukrainian terminology of astronomy.

The advantage of the constructed matrices is that besides the reflection of the already realized connections, marked by a certain sign, the empty squares enable the researcher to forecast the location of new lexical units and their ties with the existing terms. It is also of great help in the investigation of the most or the least concentration of terminological elements in the language. In comparative researches the data observed in each language separately are compared and conclusions are made on different levels.

\section{Semantic basis of English terms of astronomy \\ 1.1. Semantic typology in linguistics and terminology}

The current stage of development of linguistics is characterized by the emphasis on typological studies of languages, comparing them with other related and unrelated language systems. Semantic typology deals with expression of meaning in language and languages. Like all branches of

3 Пещак М.М. Структурування лексичного значення // Формалізовані основи семантичної класификації лексики. - Київ: Наукова думка. - 1982. - С. 56-98. 
linguistic typology, it is concerned with exploring the deep regularities which underlie the incredible diversity in how particular languages work $^{4}$. O.O. Potebnya pointed out that the very idea of comparison of all languages is the same major discovery for linguistics as an idea of mankind history ${ }^{5}$.

Semantic typology lies directly on the lines between psychology, neuroscience, anthropology, the natural sciences, and general linguistics ${ }^{6}$. It primarily studies the linguistic structures themselves and the meanings they express.

The term "typology" has many different uses. In our research typology is understood as "the study of linguistic patterns that are found cross-linguistically, in particular, patterns that can be discovered solely by cross-linguistic comparison". The terms "semantic typology" and "lexical typology" are rarely explicitly defined. Semantic typology is understood as "the systematic cross-linguistic study of how languages express meaning by way of signs" $"$. According to A.J. Lehrer lexical typology is concerned with the "characteristic ways in which language packages semantic material into words" 9 . Lexical typology can be considered a branch of semantic typology concerned with the lexicon.

Nowadays the English and Ukrainian languages not only coexist, but also interact, interpenetrate each other, constantly revealing new combinatorial possibilities, creating qualitatively and quantitatively new systematic groups of terminology ${ }^{10}$. The basic principle of comparative terminology is the principle of consistency. The main methods of systematic comparison of terminology in different languages are as follows:

\footnotetext{
${ }^{4}$ Jakobson Waugh L. On language. -Harvard: Harvard University Press, 1995. P. 5.

5 Потебня А.А. Психология поэтического и прозаического мышления/ Потебня А.А. Слово и миф. - М., 1989. С. 205.

${ }^{6}$ Talmy L. Towards a Cognitive Semantics, 2 vols. Cambridge, MA.: MIT Press. 2000. P. 5.

${ }^{7}$ Croft W. Typology and Universals / Croft W. - Cambridge : Cambridge University Press, 1993. P. 1.

8 Banczerowski J. Some contrastive considerations about semantics in the communication process // Theoretical Issues in Contrastive Linguistics. 1980. Vol. 12. P. 127.

${ }^{9}$ Lehrer A. A theory of vocabulary structure: Retrospectives and prospectives. In Thirty years of Linguistic Evolution. - Amsterdam: John Benjamins. 1992. P. 249.

${ }^{10}$ Фабіан М.П. Етикетна лексика в українській, англійській та угорській мовах. Ужгород: Інформаційно-видавниче агентство “ІВА”, 1998. С. 184 с. 
- establishment of multifaceted, complex relations between the systems of the compared languages (at the lexical, grammatical and semantic levels);

- identification of the characteristics of terminology in these languages in general and the classification of these features;

- comparison of these terminologies detecting preferential use of certain features of a particular language as well as classification of these features;

- contextual and functional analysis, which includes linguistic and quantitative analysis.

Comparative study of multilingual terminology is valuable in that it helps to make a deeper insight into the specific terminology of each language system. Comparative study of terminology is becoming more important nowadays due to the needs of information retrieval, creation of multilingual terminological data banks and scientifically based methods of teaching foreign language experts. The importance of comparative study of the terminology is clear: the creation of dictionaries and translation models based on comparative study contribute to the expansion of relations between scientists from different countries, providing exchange of scientific and technical information.

Traditionally, all languages of the world consist of common language words and words of special domains, which are grouped according to the field and target of usage. In other words, the status of every word depends on the communicative setting in which it is placed and purpose for which it is designed.

The typological study of semantics of astronomical terms assumes the following successive stages: 1) determination of lexical items which describe terms of astronomy as integrated systems that have a certain structural organization, patterns of functioning, the nature of relations between the elements of particular lexico-semantic groups; 2) description of comparable attributes and parameters in accordance with a specific methodology of formalized analysis of lexical units' semantics; 3) semantic componential analysis of astronomy terms; 4) formation of 
lexico-semantic field of terms as a fragment of lexical systems that constitutes a certain semantic space.

Typological study of language semantics can be carried out in several ways, depending on the scale and the place of the language system and on the functioning status of comparable categories. In this respect in modern linguistics there are two most common areas: 1) contrastive study of semantics on the interlingual level and 2) contrastive study of semantic phenomena at the level of one language ${ }^{11}$. The first is realized mainly in typological plane, and preferably at the level of general categories of semantic structure, the comparison of which is aimed at establishing common and different characteristics of basic forms of logical thinking. The comparison process includes units of linguistic semantics of different structural levels of one linguistic system which are based on their hierarchical nature. It is important to conduct the typological study of lexical semantics of lexicological units to penetrate into the semantics of each language in particular, as it can detect semantic nuances invisible during intra-linguistic analysis.

Investigation into the vocabulary of the English and Ukrainian language systems is one of the urgent and widespread problem of modern linguistics. It is closely connected with the construction of the typological model of the interrelation between lexical systems of two different languages. Typological study involves two connected stages: 1) highlighting the most significant features which distinguish semantics in different lexical systems; 2) combining attributes for the selected features.

The typological analysis in the current development of linguistics is made from form to content, and vice versa from content to form. The analysis of the words from meaning to content enables to identify the specific manifestations of the same meanings in different language systems namely to establish the types of interlingual equivalents and to reveal features of semantic connections in the studied languages which are characterized by dynamism. It is generally accepted that semantic change begins in polysemy. Hence a first step in understanding semantic change

${ }^{11}$ Баранник Д.Х. Аспекти зіставного дослідження мовної семантики // Матеріали Респуб. конф. “Проблеми зіставної семантики”. - Київ-Черкаси: ЧДПІ. 1992. - С. 3. 
and the processes that underlie it can be obtained by examining the semantic relations among senses of a polysemous word ${ }^{12}$.

\subsection{Lexico-semantic analysis of English terms of astronomy}

English terms of astronomy were selected from the dictionary "Oxford Dictionary of Astronomy" and their common language meanings were analysed in the explanatory one "Longman Dictionary of Contemporary English". In the present research we treat terms as both elements of common language system and words in special function denoting scientific notions. Thus, studying polysemy in our language material we take into account both common language and terminological meanings.

According to the number of common language meanings in the semantic structure of lexical units we divided our language material into three main groups: terms with the highest degree of polysemy, terms characterized by the average degree of polysemy and monosemantic terms. The group of words with the highest degree of polysemy consists of 13 terms containing more than four meanings in their semantic structure: wave, weight, balance, pressure, mantle, Sun, mass, matter, atmosphere, explosion, opposition.

The term wave is fixed in Oxford Dictionary of Astronomy in the meaning of a disturbance propagating through a continuous medium (Oxford Dictionary of Astronomy). In the explanatory dictionary this term is represented as the one denoting: 1) a line of raised water that moves across the surface of the sea; 2) a sudden increase in a particular type of behaviour, activity, or feeling; 3) a sudden increase in the number of people or things arriving at the same time; 4) the form in which some types of energy such as light and sound travel; 5) a movement in which you raise your arm and move your hand from side to side; 6) a loose curl in your hair; 7) an occasion when many people who are watching an event stand up, move their arms up and down, and sit down again (Longman Dictionary of Contemporary English). As it is obvious from the formulas of explanation, the common language meanings do not define this word as

12 Koptjevskaja-Tam M., Vanhove M., Koch P. Typological approaches to lexical semantics. Linguistic Typology 11(1): 2007. P. 166. 
a term of astronomy. In our opinion, the lexicographical entry in the explanatory dictionary can be enriched by one more meaning defining this word as an astronomical term: astr. a disturbance propagating through a continuous medium. We consider this term to be formed by means of semantic way of term formation (or terminologization) on the basis of the implicit semantic components being a part of special and common language meanings: continuous movement and increase.

In common language the word pressure is characterized by the meanings: 1) an attempt to persuade someone by using influence, arguments, or threats; 2) a way of working or living that causes you a lot of anxiety, especially because you feel you have too many things to do; 3) the force or weight that is being put on to something pressure of; 4) the force produced by the quantity of gas or liquid in a place or container; 5) a condition of the air in the Earth's atmosphere, which affects the weather (Longman Dictionary of Contemporary English). In the terminology of astronomy the term pressure denotes the broadening of spectral lines from a star due to the high pressure of gas increasing the number of collisions between atoms in a star's atmosphere (Oxford Dictionary of Astronomy). As far as common language and terminological semantics of this lexical unit display dissimilarity, we would recommend to enrich the lexicographical entry in the explanatory dictionary by one more meaning defining this lexical unit as a term of astronomy: astr. the broadening of spectral lines from a star due to the high pressure of gas increasing the number of collisions between atoms in a star's atmosphere. This term in our research can also be treated as a terminologized one on the basis of implicit common semes force and affecting.

Semantic analysis of the first group of English terms of astronomy as terminological and common language lexical units revealed general tendency of their semantics: vast variety of common language meanings fixed in the explanatory dictionary without the meaning in the sphere of astronomy being mentioned at all. In this case, we consider it necessary to add terminological meaning to the explanatory dictionary entry marking it by the lexicographical note astr. The majority of astronomy terms of this 
group were coined from the common language words by means of terminologization on the basis of their likeness.

In the group of words with the average degree of polysemy common language meanings are still represented rather widely. This group consists of 36 terms of astronomy: galaxy, nebula, zenith, accretion, phase, prominence, absorption, wavelength, eclipse, volatile, objective, radiation, constellation, limb, nucleus, light year, radiant, reflector, mare, satellite, spectrum, vibration, transit, aperture etc.

The term galaxy in terminological dictionary is explained as: $a$ collection of a million to a trillion stars, along with gas and dust all held together by gravity (Oxford Dictionary of Astronomy). In the explanatory dictionary this word is represented as denoting several meanings: astr. 1) one of the large groups of stars that make up the universe; 2) a large number of things that are similar; astr. 3) the large group of stars which our sun and its planets belong to; 4) a meeting of rich and famous people (Longman Dictionary of Contemporary English). As we see from the definitions, the first and the third meanings fixed in the explanatory dictionary define this word as a term of astronomy. These meanings are marked by the lexicographical note astr.

The term beam in Oxford Dictionary of Astronomy is defined as a stream of radiation or particles confined to a narrow range of directions. In the explanatory dictionary this term is represented as denoting: 1) astr. $a$ line of light that shines from a bright object; 2) phys. a line of radiation or particles flowing in one direction; 3) long heavy piece of wood or metal used in building houses, bridges etc; 4) a wide happy smile (Longman Dictionary of Contemporary English). The analysis of semantics of the term beam allows us to state that this term acquired meanings simultaneously in astronomy and physics. Thus, in this case we observe interdisciplinary polysemy.

The term mass in Oxford Dictionary of Astronomy denotes: $a$ measure of the amount of matter in a body. In Longman Dictionary it is fixed as: astr. 1) a large amount of a substance which does not have a definite or regular shape; 2) a large crow; 3) the amount of material in something; 4) the main ceremony in some Christian churches, especially 
the Roman Catholic Church, which celebrates the last meal that Jesus Christ ate. It is obvious that both explanatory and terminological dictionaries define this lexical unit as a term of astronomy. Besides, according to the information given by Longman Dictionary lexical unit mass can be also treated as a religious term. These relations we tend to define as homonymic, not observing explicit connections between terminological meanings in astronomy and religion.

The term wavelength in the dictionary of astronomy indicates the distance between successive peaks or troughs of a wave (Oxford Dictionary of Astronomy). In Longman Dictionary this lexical unit is explained as: 1) the size of a radio wave used to broadcast a radio signal; astr. 2) the distance between two points on energy waves such as sound or light (Longman Dictionary of Contemporary English). The semantics of this lexical unit reveals its strong scientific character, being not only a term of astronomy, but the one of physics. In the semantic space of terminology of astronomy these lexical meanings are connected by common semes distance and size.

The English words of our language material constituting the second group are in their majority terms of different sciences. In some cases, we treat this phenomenon as intersystem polysemy, tracing the same components of meaning in their semantic structure; in other cases, they can be viewed as the examples of homonymy. Most common language meanings characterizing this group are closely connected with terminological ones being in some cases primary, but in other secondary.

Monosemy is a term - concept assignment, in which one concept only is assigned to a term. Considering the alleged characteristics of terms (precision, emotional neutrality and stability), every term should be monosemantic, but this only happens with the new terms (not altered by other meanings or connotations) if they were not formed using pre-existing words, specialized or not. The monosemy of terms can be proved by the fact that it is one of the basic requirements to be met by terms. A great number of monosemantic words can be found among terms of astronomy, the very nature of which requires precision.

The third group of our material is composed of the terms the formulas of explanation of which fixed in both types of dictionaries coincide. All 
monosemantic words of our research material are only terms of astronomy. The third group includes 148 monosemantic lexical units. As far as this group is the largest one in our language material, it can be divided into several thematic subgroups.

- Names of astronomical objects: asteroid, bolide, comet.

The term bolide is a fireball accompanied by one or more audible explosions, often associated with meteorite falls (Oxford Dictionary of Astronomy). Longman Dictionary provides the same meaning: a fireball that produces a sonic boom (Longman Dictionary of Contemporary English).

- Names that indicate the trajectory of objects movement: ecliptic, axis, zodiac.

In terminological dictionary the term ecliptic is fixed as the apparent path of the Sun against the star background over the course of a year (Oxford Dictionary of Astronomy). In Longman Dictionary this term is defined similarly: the path along which the sun seems to move.

- Names of natural phenomena: eruption, explosion.

As a term of astronomy lexical unit eruption is explained as a process during which molten rock (magma) and/or volcanic ash flows to the Earth's surface (Oxford Dictionary of Astronomy). In the explanatory dictionary the meaning of the term eruption is similar to that indicated in the special dictionary: eruption the release of gas, ash, molten materials, or hot water into the atmosphere or onto the Earth's surface from a volcano... (Longman Dictionary of Contemporary English).

As we see, the definitions of monosemantic words of our language material, given by the special and explanatory dictionaries are similar and in some cases even identical. We have come to the conclusion that these lexemes have almost no connections with other words in the semantic space of the English terminology of astronomy.

\subsection{Seme analysis of English astronomy terminology}

The structure of the majority of lexical items consists of a large number of signs by which words, on the one hand, belong to different conceptual fields, on the other intercross and complement each other 
within a single lexico-semantic field. The semantic basis of astronomical words allows to single out their major and minor meanings. The definition of the astronomical terms is presented in the form of their interpretation, the semantic enrollment.

The analysis of seme composition of the English terms of astronomy is performed by means of selection of semes from words' dictionary definitions. Seme analysis of lexical unit's semantics should give deep, thesaurus definition, in which more semantic features will be highlighted ${ }^{13}$. The seme composition of the English astronomy terms, as well as the lexical one, is represented in the matrix, what enables us to treat semes as the elements of systemic and structural groups. Quantitative and qualitative characteristics of semes determine the word's semantic importance and its connections with other lexical units ${ }^{14}$.

In our research we conducted the formalized analysis of the semantics of 197 English astronomical terms. The application of componential analysis of semantics of English astronomical terms enabled us to select 111 semes from common language and terminological meanings. In the constructed matrix of the semantic space of the English terms of astronomy the list of semes is located horizontally in descending order.

According to quantitative parameter we distinguish polyfunctional semes; semes of average degree of occurrence and monofunctional semes. The polyfunctional semes in the matrix occupy the first place and unite semantics of the majority of lexical units of our material (from 39 to 11). The semes of average degree of occurrence unite the semes that were singled out from the meanings of average quantity of words (from 10 to 2). Monofunctional semes were selected from the meanings of only one lexical unit.

Most multifunctional semes reflect common language and terminological semantics. In this group the common language semantics is presented by a great number of seme realizations that form different

13 Васильев Л.М. Достоинства и недостатки компонентного анализа в семантических исследованиях // Исследования по семантике. Межвуз. сб. - Уфа: Изд-во Башкирского университета, 1984. С. 5.

${ }^{14}$ Фабіан М.П. Етикетна лексика в українській, англійській та угорській мовах. Ужгород: Інформаційно-видавниче агентство “ІВА”, 1998. С. 115. 
connections. Some examples of multifunctional semes: object, star, light, body, particle, surface, energy, mass, system, space, dust, matter, line, temperature, field etc. For instance, the polyfunctional terminological seme object is represented in terminological semantics of the following terms: nebula, parallax, gravitational lenz, scintillation, radial velocity, weight, radar, red shift, accretion disk, meteorite, azimuth, transit, asteroid etc. The same seme was detected in the common language semantics of such lexical units: pressure, mantle, phase, nadir, orbit, altitude etc. In the semantics of the term asteroid this seme was singled out from the following meaning: any of the many small rocky or metallic objects in the Solar System... (Oxford Dictionary of Astronomy).

The seme star was selected from the meanings of the terms: galaxy, white dwarf, lenticular galaxy, absolute magnitude, photosphere, luminosity, open cluster, supernova, eclipsing binary, protostar, quasar etc. The seme light is an element of the semantic structure of the terms: photon, red shift, albedo, objective, meteor, aurora, black hole, light year, light cone, reflector. The special semantics of the term spectrograph is a device for dispersing light into a spectrum... (Oxford Dictionary of Astronomy).

The semes of the average degree of occurrence are line, gravity, brightness, effect, measure, position, element, velocity, plane, hole, material, disk, wavelength, direction, sphere, explosion, core, pressure, centre, emission, diameter, movement, appearance, shadow, cluster, particle, space, portion, interval etc. For example, the polyfunctional terminological seme line represents special semantics of the following terms: pressure, radial velocity, luminosity, eclipsing binary, terminator, axis, scarp and in the common language semantics of the terms zenith and axis. The seme gravity is an element of the semantic structure of the terms galaxy, substorm, weight, atmosphere. The seme core we single out from the semantics of the term nucleus (the central core of an atom that contains most of its mass) (Oxford Dictionary of Astronomy).

The monofunctional semes of our language material are: displacement, transfer, accumulation, circle, association, practice, interaction, spin, neutral, universe, evolution, eruption, condition, circular, 
declination, flexure, depth, vector etc. The specificity of the research prompted the necessity of division of the monofunctional semes into the common language ones and those of terminological character.

According to qualitative parameter the semes of our language material are divided into: descriptive (manner, form, measure, degree, feature, qualities, condition etc.); relative (function, effect, relation, repetition, conversion, function, movement etc.); objective (element, object, particle, portion, sphere, interval, line etc.)

\section{Semantic basis of Ukrainian terms of astronomy}

\subsection{Lexico-semantic analysis of Ukrainian terms of astronomy}

The role of a dictionary, especially that of an explanatory one, which forms the empirical basis of modern semantics, is well known and generally accepted. Lexicographic practice constantly and consistently directs researchers to study lexical meaning of an individual word not as an isolated one but naturally dependent element of language system as a whole ${ }^{15}$. Explanatory dictionaries represent a concrete word in its numerous connections with other components of a word-combination and reflect lexical composition of language as a system with inherent semantic, lexicalgrammatical, stylistic connections in different correlations and oppositions.

The semantic structure of any system of words in a dictionary is a network of semantic relations observed between the words of a particular system ${ }^{16}$. The study of dictionary explanations of lexical units in our research is important as "broad analytical definitions, that we treat as the samples of more or less adequate division of meanings of one words into the meanings of other lexical units, are extremely valuable for componential analysis" $"$.

In modern lexicography the problem of terminological lexis reflection in the explanatory dictionary is relevant, though not fully investigated. The

15 Пещак М.М. Нариси 3 комп'ютерної лінгвістики: Монографія. Ужгород: Закарпаття, 1999. С. 58.

${ }^{16}$ Сорока Т.В. Особливості полісемантичної структури аксіономенів сучасної англійської мови // Сучасні дослідження з іноземної філології. Збірник наукових праць. Ужгород. Вип. 13. 2015. С. 198.

${ }^{17}$ Фабіан М.П. Етикетна лексика в українській, англійській та угорській мовах. Ужгород: Інформаційно-видавниче агентство “ІВА”, 1998. С. 43. 
complexity of this issue research is that the terminological vocabulary that enters the codified literary language from the scientific and technical sphere forms a very significant part of the vocabulary register of each common language dictionary. The specificity of the semantic characteristic of a term in the explanatory dictionary is expressed in the need to take into account scientific knowledge when characterizing the conceptual component of meaning, rigid fixation of its semantics and the possibility of choosing of the most spread understanding of the term.

The problems connected with the incorporation of terminological vocabulary into the literary language dictionary are as follows: 1) selection of terminological lexis for the dictionary; 2) correlation of extralinguistic content and semantic structure of a term with its linguistic description in the dictionary; 3) functioning of a term in a particular sphere of human activity; 4) dictionary presentation of the semantic structure of a term; 5) term combinability; 6) stylistic characteristic of a term.

Terminology dictionaries compilers are struggling with a whole range of issues that they share with lexicology. Among these issues, difficulties in the identification of terms, polysemy and synonymy, a great quantity of abbreviations, and rapid expansion of the terminological system ${ }^{18}$.

In terms of application of methodology of formalized analysis of semantics lexical units of Ukrainian terminology of astronomy were divided into three groups on the basis of their degree of polysemy: terms with the highest degree of polysemy, terms characterized by average degree of polysemy and monosemantic terms. The group of words with the highest degree of polysemy consists of 13 lexical units containing more than four meanings in their semantic structure: сонце, висота, маса, земля, оболонка, матерія, опір, сфера, тінь, вага, градус, сила, фаза.

The term соние in the Ukrainian special dictionary of astronomy indicates the closest star to us, the central body of the solar system (найближча до нас зоря, центральне тіло Сонячнӧ̈ системи) (Астрономічний енциклопедичний словник) and in the Ukrainian explanatory dictionary the meanings are the following: 1) астр. central orb

${ }^{18}$ Gordienko O. Some issues of English medical terminography in the context of English globalization // Сучасні дослідження з іноземної філології: Збірник наукових праць. Вип.17. Ужгород: ДВНЗ “УжНУ”, 2019. С. 28. 
of solar system that takes the form of hot giant ball that emits light and heat (центральне небесне світило сонячної системи, щьо має форму гігантської розжареної кулі); 2) reflection of something in something of this heavenly body (відбиття, відображення чим-небудь або у чомусь изього небесного світила); 3) light and heat emitted by this star (світло й тепло, що випромінюються иим світилом); 4) something that illuminates the way, the one who leads the way (in life, fighting, etc) (те, що освітлюе илях, той, хто веде за собою (у житті, боротьбі i m. ін.); 5) астр. central planet of other planetary systems (иентральна планета інших планетних систем) (Великий тлумачний словник сучасної української мови). As it can be seen from the definitions, the first and the fifth meanings fixed in the explanatory dictionary define this word as a term of astronomy. They are marked by the lexicographical note acmp.

The term фаза in terminological dictionary denotes: a different form of the solar system (planets, planetary satellites, asteroids, comets) which the observer sees from the Earth (Астрономічний енциклопедичний словник). The Ukrainian explanatory dictionary gives five formulas of explanation of this lexical unit: 1) period, the stage of development of a phenomenon, process, etc. (період, стадія в розвиткові якого-небудь явища, прочесу тощо); 2) the specific point in changing the shape or condition of something (положення, певний момент у зміні форми або стану чогось); 3) хім. homogeneous part of any heterogeneous physical and chemical systems (однорідна частина якої-небудь неоднорідної фізико-хімічної системи); 4) геол. the smallest period, which corresponds to a certain character species (найменший період, якому відповідає певний характер порід); 5) біол. some stage in individual development of a body (певний етап в індивідуальному розвиткові якогось організму) (Великий тлумачний словник сучасної української мови). The analysis of astronomical term allows us to state that the term фаза developed simultaneously in different fields of science, i.e.in chemistry, geology and biology. We would suggest to enrich the semantics described in the explanatory dictionary by a special meaning in astronomy. The terminological meanings in astronomy and chemistry testify to the fact 
that these meanings developed separately from the rest of special ones. Other scientific meanings are united by such common semes - nepiod, етап, момент.

The analysis of the first group of our language material showed that the terms of this group are characterized by interdisciplinary polysemy. We can state that the similarity of semantic processes in different spheres of human activity underlies this phenomenon. The similar features are observed in these terminological systems with different degrees of intensity and concern various objects.

In the group of words with the average degree of polysemy common language meanings are still represented rather widely (from 4 to 2 meanings). To this group belong 43 terms of astronomy: хвиля, тиск, орбіта, зсув, мантія, супутник, аберація, атмосфера, зірниця, конвекиія, вибух, коливання, освітленість, апогей, баланс, лавина, резонанс, спектр, термінатор, масштаб, виверження, промінь, ореол, скупчення, рефлектор, ескарп, видимість еtс.

The composition of this group of terms of astronomy allows division into several thematic subgroups.

- Names of devices, mechanisms: спектограф, рефлектор.

Cnектограф in the dictionary of astronomy is described as spectral instrument in which registers the maximum possible electromagnetic spectrum deployed in the focal plane of the optical system (Астрономічний енциклопедичний словник). Explanatory dictionary suggests two meanings of this word: 1) the optical device designed for photographing of spectra (оптичний прилад, призначений для фотографування спектрів); 2) apparatus for analyzing the composition oscillation frequency of the mechanical and electromagnetic origin (прилад для аналізу частотного складу коливань механічного та електромагнітного походження) (Великий тлумачний словник сучасної української мови). Both dictionaries suggest terminological meanings of the lexical unit, the explanatory dictionary in this case being more precise.

- Names of the orbit's point: апогей, афелій, перигелій. 
In terminological dictionary the term апогей is explained as the point of the orbit of the moon or an artificial satellite of the Earth, most distant from Earth (точка орбіти Місяця або штучного супутника Землі, найвіддаленіша від цеентра Землі) (Астрономічний енциклопедичний словник). In the Ukrainian explanatory dictionary this meaning is rendered as: астр. 1) the farthest point of the Earth's orbit of the moon or an artificial satellite (найвіддаленіма від центра Землі точка орбіти Місяия або штучного супутника Землі); 2) the highest degree of something; peak, flowering (найвищий ступінь чого-небудь; вершина, розквіт). The analysis shows that terminological and common language meanings are characterized by a common seme - вериина.

- Names that indicate the displacement of objects: паралакс, екліптика.

The term паралакс in the dictionary of astronomy is explained by one meaning: the phenomenon of apparent displacement of the body (object) (явище видимого зміщення тіла (предмета)). In the explanatory dictionary this term is represented as denoting: 1) apparent displacement of the proposed facility as a result of displacement of the observation point; 2) астр. angle measuring apparent bias lights when moving observer from one point in space to another. The first meaning in the explanatory dictionary coincides with the one fixed in the terminological dictionary. So, in our opinion, this term is polysemantic in astronomy, denoting two scientific concepts, which is demonstrated by the explanatory dictionary.

- Names connected with apparent visibility in space: промінь, освітленість, видимість.

In the Ukrainian sublanguage of astronomy according to the terminological dictionary the term промінь is polysemantic having two meanings 1) tangent which coincides with the direction of light propagation; 2) light stripe, coming from any light source or object that reflects light (Астрономічний енциклопедичний словник). The Ukrainian explanatory dictionary gives three formulas of explanation of this lexical unit: 1) acтр. fast, unexpected manifestation of something (швидкий, несподіваний прояв чого-небудь); 2) фiз. direction of propagation of energy waves (напрям поширення енергї хвиль); 3) зоол. 
bones of aquatic animals (кісточки плавиів водяних тварин) (Великий тлумачний словник сучасної української мови). It is obvious that in these interpretations of the term промінь we observe interdisciplinary polysemy- the phenomenon when terms are used in several fields of science, their terminological meanings being connected implicitly on the basis of metaphoric likeness.

Most common language meanings characterizing this group are closely connected with terminological ones being in some cases primary, but in other secondary. Ukrainian lexical units of average degree of polysemy are also characterized by the interdisciplinary polysemy of lexical units. Division of the terms into different thematic groups provided for better understanding of certain semantic features of this particular group of terms.

The investigation of the Ukrainian monosemantic terms of astronomy showed that the meanings fixed in the explanatory dictionary in most cases coincide with those suggested in terminological ones. Our research material consists of 141 monosemantic lexical units. All monosemantic terms of our Ukrainian language material are only terms of astronomy: нова зоря, відносність, анігіляція, парсек, великий вибух, електромагнітний спектр, астероїд, космічна швидкість, галактичне гало, метеор, міжзоряне середовище, метеорит, іоносфера, Кельвін, лінзоподібні галактики, світловий конус, лімб, малі планети, нововідкрита зірка еtс.

The term of astronomy парсек in the Ukraininan terminological dictionary is represented as the exogenous unit of distance in astronomy (позасистемна одиниця відстані в астрономіi) (Астрономічний енциклопедичний словник). In the explanatory dictionary it denotes: the unit of measuring the distance equal to the distance for which the annual parallax is one second (одиниця виміру відстаней, рівна відстані, для якої річний паралакс дорівнює одній секунді) (Великий тлумачний словник сучасної української мови). These two lexical meanings are rather identical being united by the semes відстань and одиниия.

The term метеop in special dictionary is explained as the phenomenon in the upper atmosphere that arise when hard particles fly 
into it (Астрономічний енциклопедичний словник). Explanatory dictionary gives the similar interpretation: a solid body of space origin, which falls with great speed in the Earth's atmosphere, a shooting star (Великий тлумачний словник сучасної української мови). The term галактика in astronomy is explained as: the giant stellar system. In the explanatory dictionary this meaning is the same: space system that consists of stars, star clusters, dust and gaseous nebulae, of diffused gas and dust. As it is obvious from the definitions, both types of dictionaries define the analyzed lexical units as the terms of astronomy. In this case we recommend marking these meanings in the explanatory dictionary by the note acmp.

Lexico-semantic analysis of the Ukrainian terms of astronomy with application of formalized approach proved that the largest group of lexical units consists of monosemantic terms. Lexical meanings provided by terminological dictionary and explanatory one are in their majority similar. Often special meaning is implicitly indicated in the explanation suggested by the explanatory dictionary. These are the cases when we recommend marking this meaning by the lexicographical note acmp.

\subsection{Seme analysis of Ukrainian astronomical terms}

Semes are the smallest elements of cognitive-semantic continuum, which are the basic building material of lexical semantics of modern language that connect not only universal cognitive-semantic scope and specific human language, but also the languages itself, regardless of their degree of kinship, descent, specificity, etc.

The study of the semantic structure of Ukrainian terms of astronomy enabled us to select 107 semes from their common language and terminological meanings. According to the amount of semantic components within the limits of lexico-semantic structure of the terms, the semes of our Ukrainian material can be described as belonging to one of the three groups: polyfunctional semes (being the elements of semantic structure of lexical units ranging from 34 to 11); semes of average degree of occurrence (selected from the words' meanings ranging from 10 to 2); 
monofunctional semes (were singled out from the meanings of only one lexical unit).

The seme composition of the Ukrainian astronomical terms is presented in the matrix and it gives a possibility to examine semes as elements of systematic - structural groups. The majority of multifunctional semes reflect common language and terminological semantics. In this group common language semantics is presented by a great number of seme realizations forming different connections. For example, the polyfunctional terminological seme тіло is represented in the special semantics of such terms as: паралакс, астероїд, фаза, афелій, метеор, метеорит, маятник, зоря, планета, затемнення, біла діра, космічна швидкість, соние еtc. In the semantics of the term соние it was singled out from the following meaning: найближча до нас зоря, центральне тіло Сонячной системи (Астрономічний енциклопедичний словник). The same seme is represented in the common language semantics of such terms: полодія, маса, протопланета, висота, опір, альбедо, акреція, супутник, суспензія. The seme елементарна частинка is the structural element of the semantics of the following terms: магнітне поле, віртуальна частинка, радіоактивність, ліброн, метеор, орбіта, квант, зодіакальне світло, мезон, атомне ядро, позитрон, спектр, кварк, протон. For example, протон - стабільна елементарна частинка, ядро протію (Астрономічний енциклопедичний словник). The seme система is a terminological seme representing special meanings of the following terms: маса, астероїд, галактика, подвійна зоря, фаза, сонще, коливання, пояс Койпера, радар, Чумаџький Шлях, Кельвін, об'єктив, рефлектор, висота. The same seme was selected from common language semantics of the terms: матерія, екліптика, радіотелескоп, ширина рівнів, акреиій ний диск, суспензія, комета, схилення, комета, Земля.

The semes of average degree of occurrence are сфера, орбіта, рух, поверхня, площина, обертання, коливання, диск, простір, речовина, середовище, температура, реакиія, одиниця, скупчення, властивість, підвищення, розмір, горизонт, траєкторія, площина, вершина, компонент, напруження, стадія, вісь, лінія еtc. For example, the 
polyfunctional terminological seme nростір is singled out in the special semantics of the terms: хвиля, сфера, магнітосфера, орбіта, космічні промені, довжина хвилі and in the common language semantics of the terms: струни, півтінь. The seme середовище is a part of semantic structure of the terms галактика, тиск, магнітосфера, локалізація, мерехтіння, суспензія, зодіакальне світло, акреція. In the semantics of the term акреція the seme середовище was selected from the meaning падіння речовини на гравітуюче космічне тіло із навколишнього середовища (Астрономічний енциклопедичний словник). The seme одиниия is a unit of the semantic structure of the terms фаза, баланс, світловий рік, маса Сония, протон, градус. The seme лінія is singled out in the lexical meanings of the terms of astronomy надгігант and нова зоря. Semantic unit блиск is a component of the semantic structure of the terms нововідкрита зірка and змінні зорі (зорі, у яких спостерігають зміни блиску хоча б в одному діапазоні) (Астрономічний енциклопедичний словник).

The monofunctional semes of the Ukrainian are: відхилення, відлік, показник, змімення, форма, координата, заряд, знак, отвір, розмивання, оболонка, тиск, смуга, заглибленняполюс, відбивати, деформація, оболонка, властивість, потік, плазма, спалах, утвори, кора, інструмент, сила, розширення, стиснення, фокусування еtс. Most monofunctional semes representing the semantics of Ukrainian terms of astronomy are of terminological character. For example, the semantic structure of the term вucoma contains the terminological seme координата in the meaning - одна з координат у горизонтальній системі небесних координат (Астрономічний енциклопедичний словник). The semantics of the term паралакс comprises the terminological seme змімення in the meaning - явище видимого змімення тіла (предмета) на тлі віддаленіших тіл у випадку змімення спостерігача. The meaning of the term сонячний вітер comprises the terminological seme потік in the meaning - безперервний потік плазми сонячної атмосфери що поширюється від Сонця у приблизно радіальних напрямках (Астрономічний енциклопедичний словник). 
The regularity of location of common language and terminological semes in the matrix represents the correlation of common language and terminological semantics of astronomy. In the semantic space of the Ukrainian language of astronomy the semes representing the semantic structure of the terms астерої (тіло, система, орбіта, відстань, розмір), фаза (тіло, система, величина, одиниця, стан, форма), Сонце (тіло, система, випромінювання), метеор (тіло, елементарна частинка, явище) display strong connections being located in the immediate vicinity in the matrix.

\section{CONCLUSIONS}

Semantic analysis of the terms of astronomy in English and Ukrainian in our research is performed with application of componential analysis and methodology of formalized analysis of lexical units' semantics, being aimed at investigation of semantic peculiarities of terms of astronomy. Matrices of semantic space of the English and Ukrainian terminological systems of astronomy were constructed. The main principle of matrix construction is rank arrangement of lexical units from the most polysemantic to monosemantic and semes from the most polyfunctional to monofunctional ones.

The analysis of the semantic space of the English and Ukrainian terms enabled us to examine such semantic phenomena as polysemy, monosemy and different connections of the investigated terms with the terminological units of other fields of study. Semantic analysis of lexical units with the highest degree of polysemy as special and common language lexemes in both languages revealed two tendencies of their semantics. In some cases, special meaning is implicitly indicated in common language explanation, thus it is recommended to mark this meaning by the lexicographical note astr. (acmp.) The opposite tendency is when the meaning in astronomy is not mentioned in the explanatory dictionary, correspondingly we suggest adding it to the rest of the meanings. In both languages in the third group of our language material common language meanings in their majority coincide with the special ones. 
Terminological monosemy in Ukrainian and English terminology of astronomy is a spread phenomenon being more characteristic of Ukrainian material than of the English one. In the semantic space, which is represented by the matrix, monosemantic lexical units occupy rather isolated place having no connections with other layers of the language system. In the Ukrainian language interdisciplinary polysemy is more spread than in English, what in the semantic space is represented by close ties between scientific meanings.

The seme composition of terms represented in the matrices allows us to examine the semes as the elements of system-structural group. A great number of multifunctional semes appeared to be the elements of terminological semantics. According to the quantitative parameter we distinguish multifunctional and monofunctional semes. The multifunctional semes occupy the first place in the matrices, uniting semantics of the majority of lexical units.

In English and Ukrainian, the parts of the matrices, reflecting the most polyfunctional semes and lexical units with wide semantics, are characterized by dense localization of semes. This testifies to their significant semantic value in the semantic space of languages. Here the astronomical semantics of English and Ukrainian terms very often coincides with that of common language vocabulary, thus the concretization is needed for their identification. In comparison with English lexical units the Ukrainian ones are not characterized by high degree of polysemy, which is reflected by smaller number of seme realizations. The number of seme realizations decreases in the direction of reduction of lexical units' polysemy and semes' frequency of occurrence. In the parts of the matrices containing monofunctional semes we can observe relatively small number of seme realizations. The semes of terminological character are arranged in isolation from each other.

Investigation of semantic basis of English and Ukrainian terms of astronomy revealed common and different features of their systemic and structural organization and identified the place and role of terms of astronomy in the language systems. 


\section{SUMMARY}

The paper deals with investigation of semantics of astronomical terminological systems in English and Ukrainian. The research is conducted with application of methodology of formalized analysis of words' semantics as terms and common language lexical units. Terminological lexis in studied on the background of semantic space of common language system with identification of its place in the lexical and semantic systems of distantly related languages, its inner structure and correlation with other terminological systems. The terms of astronomy were selected from English and Ukrainian terminological and explanatory dictionaries. The essence of methodology of the research lies in the identification of seme composition of words' lexical meanings by means of componential analysis. The synthesis of the distinguished semantic features is carried out by statistical methods, on the basis of which matrices are constructed, in the vertical order of which terms of astronomy are arranged, and in the horizontal order - the composition of semes representing meanings of the terms. The final stage of the study presupposes the comparison of the matrices' data to identify common and distinguishing features of the astronomical terminology of the two languages.

\section{REFERENCES}

1. Banczerowski J. Some contrastive considerations about semantics in the communication process // Theoretical Issues in Contrastive Linguistics. - 1980. - Vol. 12. - P. 325-345.

2. Croft W. Typology and Universals / Croft W. - Cambridge: Cambridge University Press, 1993. - 311 p.

3. Gordienko O. Some issues of English medical terminography in the context of English globalization // Сучасні дослідження з іноземної філології: Збірник наукових праць. Вип.17. - Ужгород: ДВНЗ "УжНУ”, 2019. С. 25-33.

4. Jakobson Waugh L. On language. - Harvard: Harvard University Press, 1995. $-672 \mathrm{p}$. 
5. Koptjevskaja-Tam M., Vanhove M., Koch P. Typological approaches to lexical semantics. Linguistic Typology 11(1): 2007. P. 159-186.

6. Lehrer A. A theory of vocabulary structure: Retrospectives and prospectives. In Thirty years of Linguistic Evolution. Studies in honour of Rene Dirven on the occasion of his Sixtieth Birthday. - Amsterdam: John Benjamins. - 1992. - P. 243-256.

7. Talmy L. Towards a Cognitive Semantics, 2 vols. Cambridge, MA.: MIT Press. - 2000. -503 p.

8. Баранник Д.Х. Аспекти зіставного дослідження мовної семантики // Матеріали респуб. конфер. "Проблеми зіставної семантики". - Київ - Черкаси: ЧДПІ. - 1992. - С. 3-4.

9. Васильев Л.М. Достоинства и недостатки компонентного анализа в семантических исследованиях // Исследования по семантике. Межвуз. сб. - Уфа: Изд-во Башкирского университета, 1984. - C. 3-7.

10.Гумбольдт Вильгельм фон. Избранные труды по языкознанию. Пер. с нем. - М.: Прогресс, 1984. - 397 с.

11. Пещак М.М. Нариси 3 комп'ютерної лінгвістики: Монографія. - Ужгород: Закарпаття, 1999. - 200 с.

12. Потебня А.А. Психология поэтического и прозаического мышления / Потебня А.А. Слово и миф. - М., 1989. - С. 201-235.

13. Сорока Т.В. Особливості полісемантичної структури аксіономенів сучасної англійської мови // Сучасні дослідження з іноземної філології. Збірник наукових праць. - Ужгород. Вип 13. 2015. C. 197-208.

14. Фабіан М.П. Етикетна лексика в українській, англійській та угорській мовах. - Ужгород: Інформаційно-видавниче агентство "IBA", 1998. - 256 c.

\section{SOURCES}

15. Longman dictionary of contemporary English. - London: Longman group LTD, 2000. - 1966 p. 
16. Oxford dictionary of astronomy. Ridpath Ian. Oxford: Oxford University Press, 2003.-1059 p.

17. Астрономічний енциклопедичний словник / [за загальною редакцією І. А. Климишина, А. О. Корсунь]. - Львів : Видавництво ЛНУ, 2004. - 548 с.

18. Великий тлумачний словник сучасної української мови /

[уклад. і голов. ред. В. Т. Бусел]. - К. ; Ірпінь : ВТФ “Перун”, 2001. $1440 \mathrm{c.}$

Information about the author: Rohach L. V.,

Candidate of Philological Sciences, Associate Professor at the Department of English Philology Uzhhorod National University 14, Universytetska str., 88000, Uzhhorod, Zakarpattia region, Ukraine 


\section{METHODS OF TERMINOLOGICAL COMPOSITION EXTENSION IN LANGUAGES FOR SPECIAL PURPOSES \\ IN THE GERMAN CHRISITIAN THEOLOGICAL TERMINOLOGY}

Veresh M. T.

\section{INTRODUCTION}

Linguistics has different methods and ways of expanding vocabulary in a language, including morphological, syntactic and semantic approaches, as well as borrowing. The same methods are applied to languages for special purposes and related terminology.

With regard to borrowing, the peculiarity of the linguistic situation of the Germans during the period of active borrowing of foreignlanguage lexical units is largely due to the establishment and spread of Christianity in Europe, a religion that, in its linguistic tradition, relied primarily on Latin and Greek. "Religious interferences are related to the influence of religion on language. The writing and the main layer of borrowed vocabulary in each language were subordinate to the respective religion and associated sacred language, that is, the Holy Scripture and worship services, for some historical period. Sometimes the adoption of one or another religion was of great progressive importance, because along with religion, one or another nation borrowed writing that was conducive to the development of education and, indeed,

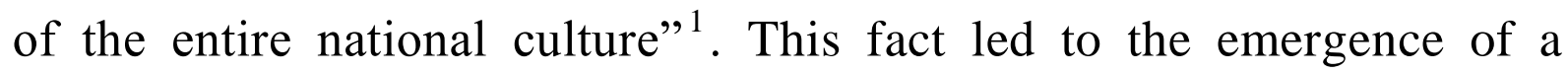
special culture of bilingualism, which consisted in the fact that, on the one hand, there was a language of religion and literary writing (in the German-speaking Latin environment), and on the other, a vernacular that was used in everyday life and partly in writing.

${ }^{1}$ Д'яков А. С. Основи термінотворення: Семантичні та соціолінгвістичні аспекти / Д’яков А. С. , Кияк Т. Р., Куделько З. Б. - К. : вид. дім “КМ Academia”, 2000 - С. 36. 


\section{Borrowing in the German Christian Theological Terminology}

Along with morphological, syntactic and semantic ways of word formation, terminology expands through borrowing.

V.N. Yartseva defines borrowing as an element of a foreign language (word, morpheme, syntactic construction, etc.), transferred from one language to another due to language contacts, as well as the actual process of transition of elements of one language into another" ${ }^{2}$ In the "Ukrainian language" encyclopaedia, the definition of the linguistic term "borrowing" is "a sound, morpheme, a word or its separate meaning, phraseology, syntactic construction, transferred from one language to another, as well as the process of subsequent transfer." ${ }^{3}$ Both definitions emphasize the importance of moving elements from one language into another. It is more often we borrow lexical units, rather than sounds and phraseologisms. A.A. Reformatskyj believes that borrowed terms are those that "do not mix with ordinary words: they are separate, unambiguous, and stand outside the expression $<\ldots>$. The choice of the source language of these terms is predetermined by real historical practice so that you can show the connection of peoples and nations and the nature of their cultural interaction". . Borrowings are moved into the language with the concept or subject they designate, depicting a cultural change, scientific and technical development ${ }^{5}$.

H.-R. Fluck extends and clarifies the definition of the term "borrowing", indicating that borrowing denotes a term taken from a foreign language and translated into the language of the recipient with its adaptation to the morphological and phonological system ${ }^{6}$.

There are many reasons, why one should know the reasons and chances for being borrowed. According to M. Haspelmath and U. Tadmor

2 Языкознание. Большой энциклопедический словар / [под ред. В. Н. Ярцевой]. [2-е изд.]. - М. : Большая Российская энциклопедия, 1998. - С. 158.

${ }^{3}$ Українська мова : енциклопедія / [Русанівський В. М, Тараненко О. О., М. П. Зяблюк та ін.]. - [2-ге вид., випр. і доп.]. - К. : Українська енциклопедія ім. М. П. Бажана, 2004. C. 194-195.

4 Реформатский А. А. Термин как член лексической системы языка / А. А. Реформатский // Проблемы структурной лингвистики. - М., 1968. - С. 120.

${ }^{5}$ Stedje A. Deutsche Sprache gestern und heute / A. Stedje. - München, 1989. - S. 25.

${ }^{6}$ Fluck, H.-R. Fachsprachen: Enführung und Bibliographie / Hans-Rüdiger Fluck. [5. überarb. und erw. Aufl.]. - Tübingen : Basel : Francke, 1996. - S. 54. 
they are: "In assessing genealogical relatedness between languages, it is important to separate inherited material from borrowed material. Loanwords point to historical contact between two languages (the presence of people with at least some knowledge of both languages at some stage), but not to genealogical relatedness (i.e. descent from, a common ancestral language). $\langle\ldots>$. The likelihood of lexical borrowing depends on the type of contact situation. $\langle\ldots>$. Borrowing patterns may be influenced by nonsocial, strictly linguistic factors",

In particular, the reasons for linguistic borrowing can be as follows:

- the need for naming (a new thing, a new concept);

- the need for clarification, the implementation of an appropriate concept,

- the need to differentiate meaningfully close, but still different concepts,

- the need for specialization of concepts in various fields and various motives;

- euphemistic substitutions;

- the tendency to replace word combinations and descriptive references with one-word naming;

- consolidation in the language of borrowing, which can be combined into a lexical series based on their general meaning and the repetition of any general structural element;

- the presence of established systems of terms in the borrowed language that serve a particular thematic area, professional environment ${ }^{8}$.

Borrowings are distinguished by several criteria, for instance, whether the way of borrowing is direct or indirect. Direct borrowing is peculiar to the language at the primary stage of formation of terminological systems when there are several borrowings from different languages at the same

${ }^{7}$ Haspelmath M. Loanwords in the Word's Languages : A Comparative Handbook / M. Haspelmath, U. Tadmor. - Walter de Gruyter, 2009. - P. 1.

8 Крысин Л. П. Языковое заимствование как проблема диахронической социолингвистики / Л. П. Крысин // Диахроническая социолингвистика. - М., 1993. C. 146. 
time to indicate the same concept ${ }^{9}$. This type of borrowing comes directly from the so called "donor language". "The language from which a loanword has been borrowed is called the donor language, and the language into which it has been borrowed is the recipient language" ${ }^{\text {. }}$. As examples would be following terms: die Kathedrale < lat. cathedralis (cathedral), der Episkopat < lat. episcopatus (bishop), das Kyrieeleison < gr. kyrios eleein (God, have mercy). Indirect borrowing occurs through a third language ${ }^{11}$. For example, der Synod <ru. sinod < gr. synodos (synod), das Schisma < lat. schisma < gr. schisma, die Theologie < lat. theologia < gr. Theologia (theology).

Noteworthy is the borrowing of "die Kirche" from the Greek word "kyriake" - "the house of the Lord" - one of the few that has been taken over by the Goths into the German vocabulary. However, the internal meaning of the term is determine by the Greek borrowing "ekklesia" (Latin ecclésia). "Ekklesia" denoted the assembly of citizens and people in classical Greek. In the Greek translation of the Old Testament (Septuagint), the word "ekklesia" is used to translate the Hebrew word "qahál" (assembly of the people of God, community). With this meaning, the word enters to the New Testament and already names all the faithful Christians, those newly chosen by God of the Jews and Gentiles, gathered in anticipation of the coming in glory of the crucified and risen Jesus Christ ${ }^{12}$.

In addition, by the nature of the borrowed material, we distinguish direct borrowing in the sense of "originals" and loan translations (or calques). "They are an important type of structural borrowing. A calque (or loan translation) is a complex lexical unit (either a single word or a fixed phrasal expression) that was created by an item-by-item translation of

9 Даниленко В. П. Русская терминология: Опыт лингвистического описания / В. П. Даниленко. - М. : Наука, - 1977. - С. 74.

${ }^{10}$ Haspelmath M. Lexical borrowing: Concepts and issues : [Електронний ресурс]. Режим доступу : https://www.academia.edu/3453003/Lexical_borrowing_Concepts_and_ issues_2009_-

$\overline{11}$ Д'яков А. С. Основи термінотворення: Семантичні та соціолінгвістичні аспекти / Д’яков А. С. , Кияк Т. Р., Куделько З. Б. - К. : вид. дім “КМ Academia”, 2000 $218 \mathrm{c}$.

${ }^{12}$ Lindquist A. Studien über Wortbildung und Wortwahl im Althochdeutschen mit besonderer Rüchsicht auf die nomina actionis / A. Lindquist // Beiträge zur Geschichte und Sprache der deutschen Literatur. - 1936. - S. 2. 
the source unit"13. D.S. Lotte applies the term "original borrowing" instead of "direct"14, since the term "direct borrowing" may refer to a borrowing path - "direct" meaning without an intermediary language. Therefore, in our work, we use the term "original borrowing".

Original borrowing is a word transferred into the recipient language in the same form it exists in the donor language ${ }^{15}$. The word borrowed with this method remains unchanged and is not affected by the morphological and phonetic system of the recipient language. For instance, die Sukzession < lat. successio, (succession) der Salvator < lat. salvator, (Saviour), das Sakrarium < lat. sacrarium (the Sacrarium).

Along with this, D.S. Lotte identifies "transformative borrowing" by which he means a word or phrase transformed at the time of translation by omitting or adding an element, or replacing a compound word with phrases $^{16}$. For example, neue Theologie < fr. Nouvelle Theologie (new theology), Fest der Kreuzerhöhung < lat. Exaltatio crucis (The Exaltation of the Holy Cross)

Calquing (loan translation) is the literal translation of word elements from the donor language into the recipient language ${ }^{17}$. This method is implemented at the beginning of language science formulation when the language has both its native word and borrowing at the same time ${ }^{18}$. For example, die Kardinaltugend < lat. virtutes cardinales (cardinal virtues), heiliges Officium < lat. Sanctum Officium (Congregation for the Doctrine of the Faith).

The materials for the study of the genetic composition of the borrowings include 2230 terminological units of the "Theologisches

${ }^{13}$ Haspelmath M. Lexical borrowing: Concepts and issues : [Електронний pecypc]. Режим доступу : https://www.academia.edu/3453003/Lexical_borrowing_Concepts_and_ issues_2009_

${ }_{14}$ Лотте Д. С. Вопросы заимствования и упорядочения иноязычных терминов и терминоэлементов / Д. С. Лотте. - М. : Наука, 1982. - С. 10.

15 Лотте Д. С. Вопросы заимствования и упорядочения иноязычных терминов и терминоэлементов / Д. С. Лотте. - М. : Наука, 1982. - С. 10-14.

16 Лотте Д. С. Вопросы заимствования и упорядочения иноязычных терминов и терминоэлементов / Д. С. Лотте. - М. : Наука, 1982. - С. 10-14.

17 Д'яков А. С. Основи термінотворення: Семантичні та соціолінгвістичні аспекти / Д’яков А. С., Кияк Т. Р., Куделько З. Б. - К. : вид. дім “КМ Academia”, 2000 C. 110 .

18 Даниленко В. П. О терминологическом словообразовании / В. П. Даниленко // Вопросы языкознания. - М. , 1973. - № 4. - С. 76. 
Fach- und Fremdwörterbuch" Dictionary by F. Hauck and G. Schwinge ${ }^{19}$. During the research process, the following have been identified: in the vocabulary of German theological terminological units of Latin origin 1508 terms - comprise the largest number of borrowings, which is $67.62 \%$ of the total number of the processed borrowings.

First of all, these are borrowings related to:

- systematic theology (die Konfession - religious denomination, die Inkarnation - Incarnation, die Dogmatik - Dogmatic theology, die Immaculata - Immaculate Mary, die Deifikation - deification;

- system and structure of the church (die Kurie - Curia, Habemus papam - We have a pope, die Konklave - papal conclave, die Kongregation - congregation, der Generalvikar - vicar general);

- Church Canon Law (die Jurisdiktion - jurisdiction, jus canonicum - canon law, die Infallibilität - Papal infallibility, ex cathedra cathedra, bishop's throne, die Exkommunikation - Excommunication, die Rota Romana - Roman Rota, the highest appellate tribunal);

- Liturgical and ceremonial areas (der Kantor - cantor, die Kapelle - chapel, die Adoration - adoration).

Such a high frequency of Latinisms in the studied terminological system is due not only to the fact that Latin has long remained dominant in the field of theology, but also because it maintains the status of a theological language today.

The second largest group contains loanwords from the Greek language, 585 terms, which is $26.24 \%$ of the total number of loans processed. Among the Greek borrowings are the following thematic groups:

- terms of church and ceremonial dress that are primarily used in the Eastern tradition (die Mitra - mitre, Panagia - Panaghia, sakkos - sakkos, omophorion - omophorion, phelonion - phelonion);

- terms of worship (Kondakion - kontakion, Troparion - troparion);

- systematic theology (philokalia - philokalia, die Theologie theology, die Theophanie - Theophany, die Eucharistie - Eucharist,

${ }^{19}$ Hauck F. Theologisches Fach- und Fremdwörterbuch / F. Hauck, G. Schwinge [10., Aufl.]. - Göttingen : Vandenhoeck \& Ruprecht, 2005. - 240 S. 
theotokos - Mother of Jesus), Holy Scripture (die Exegese - exegesis, der Exodus - Exodus, das Deuteronomium - Deuteronomy);

- terms related to church government (der Exarch - exarch).

Moreover, the dictionary includes terminological units borrowed from the ancient/biblical Hebrew language - 92 units (4.13\% of the total number of the processed loanwords). As a rule, these are concepts connected with Judaism and the Holy Scripture (der Pharisäer - Pharisees, der Sadduzäer - Sadducees, der Rabbi - Rabbi, der Sabbat - Shabbat, das Passah -Pesach, Halleluja - Hallelujah, Praise ye, Yah, der Cherubim cherub, das Hosianna - hosanna, Immanuel - God (El) with us).

Furthermore, there are loanwords from modern European languages: Italian -14 units, which is $0.63 \%$ of the total number of the processed borrowings (Bambino Jesu - Baby Jesus, die Madonna - Madonna, Santo Uffizio - Congregation for the Doctrine of the Faith, Scala santa - Scala Santa, Holy Stairs); French - 13 units, which forms $0,58 \%$ of the total amount of the analysed loan terminology (der Abbé - Abbé, das Skapulier - scapular, die Soutane - cassock or soutane). A small number of loanwords are Aramaic lexical units - ten - which is $0.45 \%$ of the total number of the examined borrowings (Golgotha - Golgotha, der Mammon - Mammon). Records of borrowing with the designation russ. is present in 5 cases - 0,23\% of the processed loanwords (archijerej archiereus, Starez - starets, Strannik - wanderer). One borrowing (0.04\% of the total number of the processed loanwords) was recorded from Old Slavic (Glagoliza - Glagolitic script), Persian (Paradies - Paradise) and Syriac (Peschitta - simple, the translation of the Bible in the Syriac of the IV th century). Quantitative indicators of borrowing terms of the Christian theological German language term system are presented in Table 1.

$67.62 \%$ of Latin borrowings in German Christian theological terminology are because the theological terminology of the German language developed under the intense influence of the classical languages, especially Latin. For a long time Latin remained the only language in the church and liturgical usage of the European peoples, including by the time of the Second Vatican Council (1962-1965). 
The borrowing of theological terms from different languages

\begin{tabular}{|l|c|c|}
\hline Languages & $\begin{array}{c}\text { The absolute } \\
\text { number of units } \\
\text { (units) }\end{array}$ & $\begin{array}{c}\text { The relative } \\
\text { amount of units } \\
(\%)\end{array}$ \\
\hline Latin & 1508 & $67,62 \%$ \\
\hline Greek & 585 & $26,24 \%$ \\
\hline ancient/biblical Hebrew & 92 & $4,13 \%$ \\
\hline Italian & 14 & $0,63 \%$ \\
\hline French & 13 & $0,58 \%$ \\
\hline Arameic & 10 & $0,45 \%$ \\
\hline Russian & 5 & $0,23 \%$ \\
\hline Old Slavic & 1 & $0,04 \%$ \\
\hline Persian & 1 & $0,04 \%$ \\
\hline Syriac & 1 & $0,04 \%$ \\
\hline Total & 2230 & $100 \%$ \\
\hline
\end{tabular}

In the German language of theology, there are cases where "specific terms that have replaced the terminological units of Greek and Latin origin remain as doublets" ${ }^{20}$ : das Glaubensbekenntnis - Credo (profession of faith), der Lobgesang - das Benediktus (hymn of praise), die Anbetung die Adoration (adoration), der Vaterunser - Paternoster (Lord's Prayer), die Erscheinung Gottes - Theophanie (The Transfiguration of Jesus).

Considering our topic, it is necessary to distinguish between internationalism and borrowing. Internationalism differs from simple borrowing: any element can only be addressed as "international" if it exists in at least three unrelated languages. If this condition is missing, then there is no reason to call a before-mentioned borrowing "internationalism", for it is only an ordinary borrowing at the national level $^{21}$. T. Sekunda believes that "international terms can be regarded as such, if they are being used with the same meaning in most European

${ }^{20}$ Arntz R. Einführung in die Terminologiearbeit / R. Arntz, H. Picht, F. Mayer. [5., verb. Aufl.]. - Hildesheim, Zürich, New York : Olms, 2004. - S.120.

${ }^{21}$ Кияк Т. Р. Запозичення та інтернаціоналізми у фахових мовах : [Електронний pecypc] / Т. Р. Кияк // Вісник Житомирського державного університету імені Івана Франка. - 2006. - № 27. - С. 32-34. - Режим доступу : http://eprints.zu.edu.ua/ 1068/1/06ktpifm.pdf. 
languages, especially highly cultural languages" 22 . Under international vocabulary, O. Kokojlo assumes words or terms that are used in the same form and with the same meanings in many languages and by peoples of Europe, Asia and other continents ${ }^{23}$. However, an important criterion for determining international and national is the presence of the word in at least three unrelated languages ${ }^{24,25}$. Internationalism is a borrowed lexical unit that exists in at least three languages with the same meaning, while retaining the overall material form and taking into account the geographical, grammatical and phonetic features of the recipient language. Frequently, the etymological basis of internationalism is the classical languages, that are Greek and Latin ${ }^{26}$.

International words are part of the vocabulary of different languages; however, etymologically they derive from the common token, both the sound structure and the semantics of which are close to each other or identical. Generally, internationalism is a lexical unit that constitutes phono-morphological variants of words or morphemes, which extend to unrelated languages and have identical or similar semantics and graphics in these languages ${ }^{27,28,29}$. Thereby, the term der Kardinal < lat. cardinalis (cardinal) has an international character, as in Ukrainian cardinal sounds (кардинал - cardinal), in Hungarian kardinális, in French cardinal. More examples are presented in Table 2.

22 Секунда Т. Принципи складання української технічної термінології / Т. Секунда // Вісник Ін-ту укр. наук. мови. - 1930. - Вип. 2. - С. 15.

${ }^{23}$ Кокойло О. В. Інтернаціональна лексика в російській та іспанській мовах / О. В. Кокойло, Н. М. Корбозерова // Мовознавство. - 1987. - № 2. - С. 27.

24 Володина М. Н. Национальное и интернациональное в процессе терминологической номинации / М. Н. Володина. - М. : Изд-во Моск. ун-та. - 1993. C. 33 .

25 Бельчиков Ю. А. Интернациональная терминология в русском языке / Ю. А. Бельчиков. - М. : Учпедгиз, 1959. - С. 3.

26 Жербило Т. В. Термины и понятия лингвистики : Общее языкознание. Социолингвистика : Словарь-справочник / Т. В. Жербило. - Назрань : Пилигрим, 2011. - С. 90.

27 Акуленко В. В. Вопросы интернационализации словарного состава языка / В. В. Акуленко. - Харьков: изд-во Харьк. ун-та, 1972. - 244 с.

${ }^{28}$ Белецкий А. А. Об интернационализмах / А. А. Белецкий // Науч. зап. Киев. ун-та. 1955. - Т. 14. - Вип. 2. - С. 59-80.

29 Бельчиков Ю. А. Интернациональная терминология в русском языке / Ю. А. Бельчиков. - М. : Учпедгиз, 1959. - 78 с. 
Table 2

Internationalisms

\begin{tabular}{|l|c|c|c|c|}
\hline $\begin{array}{l}\text { Latin/ Greek/ } \\
\text { Hebrew }\end{array}$ & German & French & Hungarian & Ukrainian \\
\hline altaria & der Altar & autel & oltár & олтар \\
\hline $\begin{array}{l}\text { amen/ amēn/ } \\
\text { àmēn }\end{array}$ & amen & amen & ámen & амінь \\
\hline $\begin{array}{l}\text { catechismus/ } \\
\text { katēchēin }\end{array}$ & $\begin{array}{c}\text { der } \\
\text { Katechismus }\end{array}$ & catechisme & katechizmus & катехизм \\
\hline cathedralis & die Kathedrale & cathedrale & katedrális & коад'ютор \\
\hline coadiutor & der Koadjutor & coadjuteur & koadjutor & колия \\
\hline $\begin{array}{l}\text { pentateuchus/ } \\
\text { pentateuchos }\end{array}$ & der Pentateuch & Pentateuque & Pentateuchus & П'ятикнижжя \\
\hline
\end{tabular}

In the Christian theological terminology of the German language internationalisms is a phenomenon, given the fact that most of the borrowed terms underlying internationalisms of this terminological system are of Latin, Greek, and Hebrew origin. Latin, for instance, has served as the primary language in theological usage for centuries and gave force to the creation of terms in specific national languages.

\section{Phraseoterms in the German theological terminology}

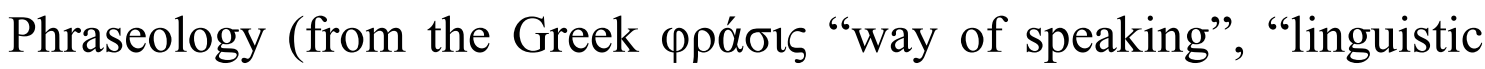
appeal" and $\lambda$ ó $\gamma o \varsigma$ science) was previously defined as an 'oratorical expression'. Ch. Palm describes phraseology as "the science or doctrine of the permanent word combinations of the language, which can take over the functions and meanings of individual words (tokens) in the system and in the sentence. That is why phraseology is the means of expanding (enriching) the vocabulary composition, for nomination" 30 .

Currently, phraseology is regarded as a unit of linguistics, which deals with phraseologisms. W. Fleischer considers phraseologisms to be syntactic phrases that are different from free phrases and contain at least one autosemantic element ${ }^{31}$.

${ }^{30}$ Palm Ch. Phraseologie. Eine Einführung / Ch. Palm. - Tübingen, 1995. - S. 1.

${ }^{31}$ Fleischer W. Phraseologie der deutschen Gegenwartssprache / W. Fleischer. Tübingen: Max Niemeyer Verlag, 1997. - S. 29-37, 62-65. 
Ch. Bally defines phraseology a complex expression which encompasses "a group of words where every graphic unit of this group loses some of its meaning or even retains no meaning at all; the combination of these elements acts as an integral content unit" ${ }^{\prime 32}$.

As to their form, phraseological units do not differ from free phrases. The difference is in the general semantics, since idioms present a peculiar two-level meaning; namely, they are carriers of proper verbal meaning and phraseological meaning. To put it differently, the verbal meaning is associative, has hidden meaning, while the phraseological is the actual meaning. In some instances, based on the meaning of the individual elements of the expression, we can determine the meaning of the whole phraseology. "The fact that phraseologies have an integral meaning that does not coincide with the meaning of the individual elements does not mean that there is no link between the total verbal meaning on the one hand and the phraseological meaning on the other. On the contrary, if we compare both meanings, it is often possible to establish a relation between them",33.

Considering the semantic features of phraseologies in the language, we should note that the phraseological units reveal certain features in the course of the phraseological meaning formation; the phraseological unit is subject to double semantic influence. On the one hand, "it is the bearer of certain interpreted pre-verbal meanings, based on which the meaning of the phraseological unit was formed, i.e. the systematic content. On the other hand, the use of in the discourse of linguistic units with actualized elements of systemic meaning generates new content which is verbalized by secondary nomination signs" ${ }^{\text {34 }}$. K. D. Pilz believes that phraseologies consist of at least two words, forming a verbal group/syntagms, which, although written separately, but are elements of one semantic unit. This group of words is fixed by its elements and acts as an equal unit in the

${ }^{32}$ Bally Ch. Traite de stylistique francaise / Ch. Bally. - [2. Aufl.]. - 2. Bd. Heidelberg, 1921. - S. 65-66.

${ }^{33}$ Burger H. Handbuch der Phraseologie / H. Burger, A. Buhofer, A. Sialm. - Berlin, 1982. - S. 3.

34 Альфиренко Н.Ф. Фразеология в свете современных лингвистических парадигм : Монография / Н. Ф. Альфиренко. - М. : Элипс, 2008. - С. 27. 
vocabulary composition; it is a token, which belongs to the language and is not recreated in the spoken language but used from its vocabulary ${ }^{35}$. Semantically, the peculiarity of the usage of phraseology also depends on "how an idiom differs from its non-phraseological equivalent; this implies the way this phraseologism modifies the possible and typical expressions into which it is embedded"36.

Phraseoterms are usually terminological expressions, the meaning of which is primarily defined only within the professional linguistic system. Phraseoterms can perform various pragmatic functions in the text; it depends on certain factors, including communication. In our case, theology is the language for special purposes. Phraseologisms in languages for special purposes are quite extensive and require a particularly careful approach to their study. Therefore, H. Burger, I. M. Vignans'ka, M. Dume, R. Eckert, O.A. Zhilenko, O. I. Molotkov, K. D. Pilz, N.V. Podols'ka, O. V. Superans'ka V. Fleischer and others investigate this topic.

With regard to phraseological terms, we should highlight that distinguishing common phraseological units and professional ones is considered a difficult task. The phraseological terms of Christian theological terminology form a particular group of expressions that function "as a separate word-term" $"$. Precisely, their semantics are clearly outlined, that is, normalized, and that it happens within the professional language. The integrity of professional phraseological units, depending on the professional context, is expressed differently. R. Eckert believes that multi-component terms and established professional expressions belong to phraseology and are regarded as phraseological units ${ }^{38}$. Another group of linguists do not perceive multi-component expressions as elements of phraseology. Thus, A. Molotkov denies the transfer of the scheme of phraseology formation through the reinterpretation of basic phrases into

\footnotetext{
${ }^{35}$ Pilz K. D. Phraseologie: Redensartenforschung / K. D. Pilz. - Stuttgart, 1981. - S. 20.

36 Kühn P. Pragmatische und lexikographische Beschreibung phraseologischer Einheiten: Phraseologismen und Routineformeln // Studien zur neuhochdeutschen Lexikographie IV. - [hrgb. Wiegand, H.E.]. - Hildesheim, Zürich, New York, 1984. - S. 195.

${ }^{37}$ Burger. H. Phraseologie. Eine Einführung am Beispiele des Deutschen / H. Burger. Berlin : Erich Schmidt Verlag, 2003. - S. 50.

${ }^{38}$ Eckert R. Die Phraseologie der russischen Sprache / R. Eckert, K. Günther. - Leipzig, Berlin, 1992. - S. 58.
} 
the formation of terminological phrases" ${ }^{39}$. V. Thalia shares the same opinion, regarding as phraseoterms only those terminological phrases that, unlike ordinary phrases, indeed, contain terminological character as a special character and have undergone a process of semantic reinterpretation ${ }^{40}$. Fleischer concludes that the main difference between terminological expressions, on the one hand, and non-terminological phraseologisms, on the other, is the same as between term and non-term ${ }^{41}$. Each term has its conceptual field, so it is independent of context and is professionally oriented.

Unlike V. Fleischer, another German researcher, H. Burger, assumes that terms should be included in phraseology. He substantiates his argument by the fact that many professional statements are present in everyday usage. Burger considers as phraseological units not only those terminological phrases that in everyday language reveal "secondary metaphorization, in addition to it, as terminological phrases that are part of everyday use $\mathrm{e}^{42}$. In this case, we are talking about the so-called "semiprofessiona"" texts, in which professional knowledge is passed on to non-specialists. In relation to Christian theological texts, they include the Catechism of the Catholic Church, which, in fact, was written for laymen, non-specialists, as well as a number of works that serve to teach them, including the "Grundkurs Christentum" (the elementary course of Christianity) by Fr. Peter Karl Wallner, monk of the Order of the Cistercians, rector of the Pontifical High School of Heiligenkreuz in Austria. For instance, set expressions from the edition Die Eucharistie: in die Kirche gehen (to go to (the) church; both literally and figuratively) ${ }^{43}$, Gott bei uns, Gott mit uns (hebr. "Immanuel”) (God (El)

\footnotetext{
${ }^{39}$ Молотков А. И. Основы фразеологии русского языка / А. И. Молотков. - Л. : Наука, 1977. - С. 61.

${ }^{40}$ Талия В. Н. Исследования по фразеологии / В. Н. Талия // Теоретические проблемы советского языкознания. - М. : Наука, 1968. - С. 272.

${ }^{41}$ Fleischer W. Phraseologie der deutschen Gegenwartssprache / W. Fleischer. Tübingen: Max Niemeyer Verlag, 1997. - S. 72.

${ }_{42}$ Burger. H. Phraseologie. Eine Einführung am Beispiele des Deutschen / H. Burger. Berlin : Erich Schmidt Verlag, 2003. - S. 51.

${ }^{43}$ Wallner K. Die Eucharistie / Pater K. Wallner. - Leipzig : St. Benno-Verlag, 2010. S. 7.
} 
with us) $)^{44}$, der Kuss der Liebe (holy kiss, the kiss of peace) ${ }^{45}$. Phraseological units of this type are either non-idiomatic or insignificantly idiomatic; they are rather semi-idioms/semi-fixed expressions.

M. Dume puts forward several criteria for phraseology in languages for special purposes; in particular, he argues that under certain conditions, the terms of a particular language for special purposes can be regarded as phraseological units. In the language for specific purposes the criteria that define or classify phraseological units (among others, idiomaticity, persistence, conventional usage, lexicalization, reproduction), are essential determinants for phraseological terms, which are now used not for the common language, but the language for special purposes. Phraseological terms are the link between phraseological units and terms. Phraseological terms, according to the definition of phraseology, should always form a group of words, while terms can exist independently as separate words. Phraseological terms can be both idiomatic and non-idiomatic. V. Fleischer's theory changes partially because of the above-mentioned criteria. He rejects the inclusion of phraseological terms into the group. Provided that the above criteria are accepted in the framework of languages for specific purposes studies, we can assume when terms may be defined as phraseological unit in turn, leading us to a transparent extension of the meaning of the phraseology in the study of languages for special purposes $^{46}$.

Furthermore, the conducted analysis based on E. Agricola's dictionary using I. Chernysheva's classification ${ }^{47}$, made it possible to identify the following features in the Christian theological terminology of the German language:

- 28 phraseological unities were recorded:

${ }^{44}$ Wallner K. Wer glaubt wird selig / Pater K. Wallner. - Regensburg : Lübbe, 2009. S. 9.

${ }^{45}$ Wallner K. Die sieben Sakramente / Pater K. Wallner. - Leipzig : St. Benno-Verlag, 2010. - S. 17.

46 Duhme M. Phraseologie der deutschen Wirtschaftssprache: eine empirische Untersuchung zur Verwendung von Phraseologismen in journalistischen Fachtexten / M. Duhme. - Essen : Die Blaue Eule, 1991. - S. 64.

47 Чернышева И. И. Фразеология современного немецкого языка / И. И. Чернышева. - М. : Высшая школа, 1970. - С. 39-46. 
seinen Tag von Damaskus erleben (to convert), das Gelobte Land (the Promised Land), vom Saulus zu Paulus werden (change belief, Conversion of Paul the Apostle), Licht der Welt (the Light of the World), bei Sankt Petrus anklopfen (dying), der barmherzige Samariter (Lk 10, 25-37) (the Good Samaritan);

- 67 phraseological expressions: die Geheimnisse des Rosenkranzes (Mysteries of the Rosary), Heilige Stiege (Scala Santa, Holy Stairs), das babylonische Exil der Päpste (The Avignon Papacy/ the papal exile in Avignon), geschlossene Zeit (closed time/ forbidden time), den Himmel auf Erden haben (to live as in Heaven on Earth), des Menschen Wille ist sein Himmelreich (Man's will is his Heaven), Römisches Messbuch (Roman Missal) and

- 158 phraseological combinations:

der bittere Kelch des Leidens (hard fate).

\section{CONCLUSIONS}

Thus, we can conclude that borrowings in the German theological terminology are very common. The fact, that Latin and Greek were considered for the long period as the languages of the Church it had also influence on the theological terminology as such.

Terminological phraseological unit is a linguistic unit consisting of two or more words, with relatively fixed structure, holistic by meaning, and meets the specifications of both term and phraseology; is existent and quite common in the Christian theological terminology of the German language.

\section{SUMMARY}

Overall, during the etymological analysis of 2230 German Christian theological borrowing terms we have revealed that by origin, Latin and Greek terms form the largest group (67.62\% and $26.24 \%$ respectively) of the total number of borrowed terms. Borrowings from the Hebrew language represent $4.13 \%$ of the analyzed terminological units. The reason for such a large number of borrowings from Latin and Greek is due to the early translations of the Bible into these classic languages, which for a long 
time remained the main means of communication. In addition, the theological writings of the church fathers and much of the theologians' were written in Latin, and fewer in Greek. All of these factors have contributed to the borrowing of such a significant number of Christian theological terms.

Regarding the way borrowings become part of a language, the largest group is direct borrowing, $87 \%$ of all the analyzed terminological units. The remaining $13 \%$ are indirect. The analyzed borrowing terms convey specific concepts of theology and are characterized by high accuracy in designation and denomination.

In the studied terminological system phraseologisms are quite widespread. The phraseological terms of the German Christian theological terminology form a special group of expressions, the semantics of which are normalized within the professional language of theology. Phraseoterms form their own conceptual field, they are professionally oriented. We have recorded 28 phraseological unities, 67 phraseological expressions and 158 phraseological combinations.

\section{REFERENCES}

1. Акуленко В.В. Вопросы интернационализации словарного состава языка / В. В. Акуленко. - Харьков: изд-во Харьк. ун-та, 1972. - $244 \mathrm{c}$.

2. Альфиренко Н. Ф. Фразеология в свете современных лингвистических парадигм : Монография / Н. Ф. Альфиренко. - М. : Элипс, 2008. - 271 с.

3. Белецкий А. А. Об интернационализмах / А. А. Белецкий // Науч. зап. Киев. ун-та. 1955. - Т. 14. - Вип. 2. - С. 59-80.

4. Бельчиков Ю. А. Интернациональная терминология в русском языке / Ю. А. Бельчиков. - М. : Учпедгиз, 1959. - 78 с.

5. Бельчиков Ю. А. Интернациональная терминология в русском языке / Ю. А. Бельчиков. - М. : Учпедгиз, 1959. - 78 с.

6. Володина М. Н. Национальное и интернациональное в процессе терминологической номинации / М. Н. Володина. - М. : Изд-во Моск. ун-та. - 1993. - 112 с. 
7. Д'яков А.С. Основи термінотворення: Семантичні та соціолінгвістичні аспекти / Д'яков А. С., Кияк Т. Р., Куделько 3. Б. К. : вид. дім "КМ Academia", 2000 - 218 с.

8. Даниленко В. П. О терминологическом словообразовании / В. П. Даниленко // Вопросы языкознания. - М. , 1973. - № 4. C. 76-85.

9. Даниленко В. П. Русская терминология: Опыт лингвистического описания / В. П. Даниленко. - М. : Наука, - 1977. - 246 с.

10. Жербило Т. В. Термины и понятия лингвистики : Общее языкознание. Социолингвистика : Словарь-справочник / Т. В. Жербило. - Назрань : Пилигрим, 2011. - 280 с.

11. Кияк Т. Р. Запозичення та інтернаџіоналізми у фахових мовах : [Електронний ресурс] / Т. Р. Кияк // Вісник Житомирського державного університету імені Івана Франка. - 2006. - № 27. - С. 32-34. Режим доступу : http://eprints.zu.edu.ua/1068/1/06ktpifm.pdf.

12. Кокойло О.В. Інтернаціональна лексика в російській та іспанській мовах / О.В.Кокойло, Н.М.Корбозерова // Мовознавство. - 1987. - № 2. - С. 27-32.

13. Крысин Л. П. Языковое заимствование как проблема диахронической социолингвистики / Л. П. Крысин // Диахроническая социолингвистика. - М., 1993. - С. 131-151.

14. Лотте Д. С. Вопросы заимствования и упорядочения иноязычных терминов и терминоэлементов / Д. С. Лотте. - М. : Наука, 1982. $-152 \mathrm{c}$.

15. Молотков А. И. Основы фразеологии русского языка / А. И. Молотков. - Л. : Наука, 1977. - 284 с.

16. Реформатский А. А. Термин как член лексической системы языка / А. А. Реформатский // Проблемы структурной лингвистики. М., 1968. - С. 103-126.

17. Секунда Т. Принципи складання української технічної термінології / Т. Секунда // Вісник Ін-ту укр. наук. мови. - 1930. Вип. 2. - С. 11-21. 
18. Талия В. Н. Исследования по фразеологии / В. Н. Талия // Теоретические проблемы советского языкознания. - М. : Наука, 1968. - C. 257-277.

19. Українська мова : енциклопедія / [Русанівський В. М, Тараненко О. О., М. П. Зяблюк та ін.]. - [2-ге вид., випр. і доп.]. - К. : Українська енциклопедія ім. М. П. Бажана, 2004. - 824 с.

20. Чернышева И. И. Фразеология современного немецкого языка / И. И. Чернышева. - М. : Высшая школа, 1970. - 200 с.

21. Языкознание. Большой энциклопедический словарь / [под ред. В. Н. Ярцевой]. - [2-е изд.]. - М. : Большая Российская энциклопедия, 1998. -685 c.

22. Arntz R. Einführung in die Terminologiearbeit / R. Arntz, H. Picht, F. Mayer. - [5., verb. Aufl.]. - Hildesheim, Zürich , New York : Olms, 2004. - $331 \mathrm{~s}$.

23. Bally Ch. Traite de stylistique francaise / Ch. Bally. - [2. Aufl.]. 2. Bd. - Heidelberg, 1921. - 332 S.

24. Burger H. Handbuch der Phraseologie / H. Burger, A. Buhofer, A. Sialm. - Berlin, 1982. - 433 s.

25. Burger. H. Phraseologie. Eine Einführung am Beispiele des Deutschen / H. Burger. - Berlin : Erich Schmidt Verlag, 2003. - 130 s.

26. Duhme M. Phraseologie der deutschen Wirtschaftssprache: eine empirische Untersuchung zur Verwendung von Phraseologismen in journalistischen Fachtexten / M. Duhme. - Essen : Die Blaue Eule, 1991. $222 \mathrm{~s}$.

27. Eckert R. Die Phraseologie der russischen Sprache / R. Eckert, K. Günther. - Leipzig, Berlin, 1992. - 267 S.

28. Fleischer W. Phraseologie der deutschen Gegenwartssprache / W. Fleischer. - Tübingen: Max Niemeyer Verlag, 1997. - 310 s.

29. Fluck, H.-R. Fachsprachen: Enführung und Bibliographie / HansRüdiger Fluck. - [5. überarb. und erw. Aufl.]. - Tübingen : Basel : Francke, 1996. - 359 s.

30. Haspelmath M. Loanwords in the Word's Languages : A Comparative Handbook / M. Haspelmath, U. Tadmor. - Walter de Gruyter, 2009. - $1081 \mathrm{p}$. 
31. Hauck F. Theologisches Fach- und Fremdwörterbuch / F. Hauck, G. Schwinge - [10., Aufl.]. - Göttingen : Vandenhoeck \& Ruprecht, 2005. - $240 \mathrm{~S}$.

32. Kühn P. Pragmatische und lexikographische Beschreibung phraseologischer Einheiten: Phraseologismen und Routineformeln // Studien zur neuhochdeutschen Lexikographie IV. - [hrgb. Wiegand, H.E.]. Hildesheim, Zürich, New York, 1984. - S. 175-235.

33. Lindquist A. Studien über Wortbildung und Wortwahl im Althochdeutschen mit besonderer Rüchsicht auf die nomina actionis / A. Lindquist // Beiträge zur Geschichte und Sprache der deutschen Literatur. - 1936. - S. 1-132.

34. Palm Ch. Phraseologie. Eine Einführung / Ch. Palm. - Tübingen, 1995. $-224 \mathrm{~s}$.

35. Pilz K. D. Phraseologie: Redensartenforschung / K. D. Pilz. Stuttgart, 1981. - $147 \mathrm{~s}$.

36. Stedje A. Deutsche Sprache gestern und heute / A. Stedje. München, 1989. - 281 s.

37. Wallner K. Die Eucharistie / Pater K. Wallner. - Leipzig : St. Benno-Verlag, 2010. - 95 s.

38. Wallner K. Die sieben Sakramente / Pater K. Wallner. - Leipzig : St. Benno-Verlag, 2010. - 95 s.

39. Wallner K. Wer glaubt wird selig / Pater K. Wallner. Regensburg : Lübbe, 2009. - 350 s.

\section{Information about the author: Veresh M. T.,}

$\mathrm{PhD}$ in Germanic Languages, Associate Professor at the Faculty of Foreign Philology, Department of German Philology

Uzhhorod National University 3, Narodna Sq., 88000, Uzhhorod, Ukraine 


\title{
SPECIALIZED MEDICAL INFORMATION SPACE: HISTORY AND PRINCIPLES OF FORMATION
}

\author{
Sadivnychyi V. O.
}

\section{INTRODUCTION}

During actively scientists' exploring the different spheres of multitude databases, movement of information flows and structural elements of the information space, there is a classic idea that the information space is the environment in which information is produced and rotated and interaction in the process of common activity takes place. It's a collection of information, information infrastructure and subjects that collect, generate, disseminate and use information. Also it's a collection of information resources, a territory of information dissemination. In this work, the notion of information will be understood as a space that consists of information of different levels intended for its transmission to consumers.

The main structural components of the information space are information spheres and information flows. The information sphere is the totality of all concentrated in space information, regardless of its form and state, where "not physical, but logical-algorithmic information laws operate" . Information flow is "a collection of information that moves in the information space through communication channels. Information flows can flow both within and between individual infospheres, depending on the availability of communication channels"2.

Society's need in information has long been both widespread and differentiated. Differentiation is primarily about the desire to satisfy

${ }^{1}$ Кононович В. Г. Визначення інформаційного поля 3 позицій інформаційної безпеки. “АВIA-2011”: Матеріали X міжнародної науково-технічної конференції. Секція 2 - Інформачійна безпека. Київ : НАУ, 2011. Ст. 2.37.

2 Плескач В. Л., Затоноцька Т. Г. Інформаційні системи і технології на підприємствах : підручн. Київ : Знання, 2011. 718 с. URL: http://pidruchniki.com/ 1350052747708/informatika/ponyattya_informatsiynogo_prostoru (дата звернення: 15.02.2020). 
information interests related to more or less specialized knowledge: from the elemental desire to know (to take an umbrella or to leave it at home), to the desire to use freely complex household or professional appliances.

The professionals need the relevant content information, which is specialized, for orientation in professional activity, first of all, for solving problem situations and generating new knowledge in the chosen sphere.

In general, human, as a biological creature, constantly adapts the body to existing conditions, struggling for survival. And any topics become minor as soon as a health or life-threatening problems arise. In such extreme situations, human actions, as social creature, are based on knowledge, gained either in the course of the society development or at the time of the threat of life or health. And in this case the basic information becomes specialized, namely medical: the need for the population to obtain and understand information about health, illness, their prevention and treatment are caused by an elementary instinct for self-preservation.

The segment of specialized medical information in the information space was gradually filling: from drawings of the human body to the first printed and electronic anatomical tables; from the cuneiform text of Mesopotamia to the reproduction of printing and electronic classification of diseases; from the system of medicine, shamanism, hairdressing through the first medical faculties opening in the XII century to the current world system of training medical workers; from an introduction the first specialized books of medical history in the XIV-XV centuries to the present international unity of methodological approaches of clinical materials recording and comparison.

Scientific medicine in the second half of the XIX century was formed into a significant specialized segment of the information space from the beginning of its birth, dating to VI. B.C. (thanks to the accumulated information about human anatomy and physiology, diagnosis and treatment). The components of this segment have changed, new principles of dissemination, processing and storage of information have emerged and the existing principles have been improved.

The development of medicine is also closely linked to scientific exchange, from its first intuitive ideas to formation in the scientific 
knowledge system, from the advent of books and then periodicals, which took over the functions of disseminating new information and its promoting. The works on various problems of medicine were published in scientific journals of the general profile by the second half of the XVII century. One of these is "Journal des sçavans" (Paris, 1655-1792), which published papers about brain anatomy, pharyngeal muscles, and other spheres of medicine. The first special medical journal is "Nouvelles descouvertes sur toutes les parties de la médecine" (1679-1681), published by a Paris surgeon Nikola Blégny. More than 170 medical journals and periodical scientific papers in medicine were published in the beginning of the XVIII century according to encyclopedic data ${ }^{3}$.

\section{Socio-communicative parameters of the medical press}

Over time, the medical media found its place in the social communication system, gaining own readership. The community of significant attributes, which include technological, classroom, informational, functional, organizational and editorial, gives the grounds to position specialized medical periodicals and continuing editions as a single typological group.

We were based on several significant approaches concerning a selecting these editions and introducing them as an object in the sphere of social communication sciences.

The first of these approaches concerned the definition of the medicine concept and its distribution by spheres. This word comes from the Latin "medicina" - medicinal, therapeutic. It is defined as the set or cycle of the sciences about disease and health, treatment and prevention, health, the art of its preserving, and also the search for healing methods; as a system of scientific knowledge and practical actions united by one purpose - to recognize or diagnose diseases. The following definition is most commonly repeated in various sources: "Medicine is a system of scientific knowledge and practice which aims are promoting and preserving health, extending human life, preventing and treating human disease"4. Health in

3 Медицинская периодическкая печать. Большая медицинская энцุиклопедия Москва : Советская энциклопедия, 1980. Т. 14. Ст. 377.

4 Медицина. Большая медицинская энциклопедия. Москва : Советская энциклопедия, 1980. Т. 14. СТ. 3. 
scientific sources is defined as "the condition of optimal vital activity, which ensures the full realization of its essence" 5 .

And if humane medicine deals with human health, then veterinary medicine covers the system of biomedical sciences and practical actions for the prevention and treatment of animal diseases. The interconnection of medicine is inextricable and intended, primarily, to protect people from socalled zooanthroponosis - a disease that is transmitted in different ways from humans to animals.

Homeopathy is considered to be a kind of "therapeutic system, which originated on the principle of disease control drugs that cause in healthy person phenomena similar to the symptoms of the disease" 6 (from the Greek. Homoios - similar; pathos - suffering, illness). This treatment is based on the principle of "similar to similar". The founder is German doctor Samuel Hahnemann (1755-1843).

The human health system is also targeted at a food system in which people don't consume animal products - vegetarian.

We also proceeded with the statement that medicine as a system combines "theoretical, experimental, clinical and prophylactic components. Theoretical medicine is based on the basic sciences (biology, physics, chemistry, mathematics, psychology, sociology). The theory of anthropogenesis, the theory of norms, the theory of pathology can be highlighted as its basic components. Experimental medicine combines the research method theory, the experiment theory, the modeling theory, the results prediction theory. Clinical medicine includes the theory of human personality, the theory of diagnostics, the theory of treatment (psychosomatic optimization), the theory of rehabilitation, the theory of values. Preventive medicine includes the theory of hygiene, the theory of anthropoecology, the theory of prevention, the theory of health care" 7 .

The socio-communicative mechanism of medical information is based on the system of specialized knowledge dissemination in the information

${ }^{5}$ Соціально-філософські та етичні проблеми медицини : навч. посіб. ; за заг. ред. А. П. Алексеєнко, В. М. Лісового. Харків : Колегіум, 2010. Ст. 25.

6 Гомеопатия. Больщая медицинская энцңиклопедия. - Москва : Советская энциклопедия, 1977. Т. 6. Ст. 307.

${ }^{7}$ Соціально-філософські та етичні проблеми медицини : навч. посіб. ; за заг. ред. А. П. Алексеєнко, В. М. Лісового. Харків : Колегіум, 2010. Ст. 17-18. 
space. The distribution system included closed and open channels: private and official correspondence, exchange of scientific papers, documents dissemination of scientific and practical content, promulgation of the scientific researches results or practical observations at conferences, congresses, meetings, preparation of research descriptions for publication, publication of materials in periodicals, preparation for printing and reproduction of books and brochures, formation of specialized medical libraries, etc.

Scientific empirical and theoretical, scientific-practical, practical and other knowledge in medicine formed a separate segment in the information space.

The specialized medical information space "is an environment that provides the production, collecting, storage and distribution of the thoroughly tested, documented, accurate, accessible, valid information of medical and biological content, that gives the opportunity of information interexchange for agents in order to meet their information needs, providing epidemiological studies, statistical measurement, treatment and prevention or scientific research",

The main focus of the specialized medical information space is to address the challenges of the institutional health care system by ensuring the communicative functions of the area.

The second significant approach is related to the distribution of editions on periodicals and continuing, magazines, newspapers, sheets, and books.

According to the standard, the periodical is "an edition that is published at regular intervals, has a predetermined constant annual number and the name of numbered or dated, uniquely designed issues that are not repeated in content". And the continuing edition is "an edition that is published at indefinite intervals, as the material accumulates, numbered and (or) dated issues, unrepeatable in content, uniquely designed, with a common name". The main type of periodical media is the newspaper -

${ }^{8}$ Садівничий В. О. Становлення вітчизняного інформаційного простору в сегменті медичної преси наддніпрянської україни XIX - початку XX століть: типологія, функціонально-змістові особливості, комунікативно-прагматичні складники : дис. ... д-ра наук із соц. комунік : 27.00.04. Київ, 2015. 481 с. Ст. 23. 
"an edition with a permanent name, published in certain, short periods of time, contains official documents, operational information and materials on topical socio-political, scientific, industrial and other issues, and also literary works, photographs and advertising".

As a periodical and continuing edition, the magazine is a "periodical, which is published with a permanent name, has permanent columns, and contains articles, abstracts, other materials on various socio-political, scientific, industrial and other issues, literary works, illustrations, photographs"9.

As a media, magazine "has the following features: infinity and regularity of publication of numbers at certain intervals, published materials in the form of articles, ... a certain thematic direction of contents, ... special printing design, ... a permanent editorial board" $"$.

We selected the editions for analysis by these approaches, grouping them into specialized medical periodicals and continuing editions.

We started from the fact that specialized medical periodicals and continuing editions are "a special type of mass media with its problematic and thematic direction, internal structure, and clear auditorium"11.

\section{Specialized medical information space: main features}

The specialized medical information space of Naddniprianshchyna in the second half of the XIX - beginning of the XX centuries characterized by the development of social institutions (higher education institutions, scientific and other societies, research organizations, medical institutions); richness of the generated and reproductive medical knowledge; professional communication agents (medical scientists, medical practitioners and clinicians, nursing staff, students); corporate using; a community of typological features whose properties are defined by information infrastructure; the fact that there are specialized medical periodicals and continuing editions.

${ }^{9}$ ДСТУ 7152:2010. Видання. Основні види: Терміни та визначення. [Чинний від 1996-01-01]. Вид. офіц. Київ, 1995. 48 с. (Інформація та документація). Ст. 10, 12, 16.

${ }^{10}$ Семистяга Т. Видавничо-поліграфічна галузь України: динаміка й проблеми розвитку (2002-2004 роки). Друкарство. 2005. № 2. Ст. 7.

${ }^{11}$ Садівничий В. “Відродження розпочинається із гласності...” : (Медична преса Наддніпрянської України середини XIX - початку XX ст.) : монографія. Дніпропетровськ : Середняк Т. К., 2015. Ст. 83. 
In the period from 1860 to 1920 (chronological boundaries caused by the development of socio-political events), 186 specialized medical periodicals and continuing editions were published in 9 provinces of Naddniprianshchyna (Volyn, Katerynoslav, Kyiv, Podil, Poltava, Tavriy, Kharkiv, Kherson, Chernihiv).

Our calculations are based on the following analysis: a) catalogs of leading library institutions: Vernadskyi National Library of Ukraine, National Academy of Sciences of Ukraine, National Scientific Medical Library of Ukraine, Kharkiv Korolenko State Scientific Library, Odesa National Scientific Library, Russian National Library (St. Petersburg); b) catalogs of libraries of former provincial centers, departmental and higher educational institutions; c) recorded data from scientific and bibliographic sources, etc. We have identified a number of editions in only one copy and only in one of the libraries. The bibliographic catalogs and indexes of the retrospective plan were a considerable array of research sources. Historical and bibliographical works and catalogs, organized by creative scientific teams, were of great importance.

The analysis made it possible to state that specialized medical periodicals and continuing editions of Naddniprianshchyna were published in 26 cities. Most of these editions - 52 - were recorded in Kyiv, 35 were published in Odesa, 34 - in Kharkiv. Further indicators are significantly decreasing and are: Katerynoslav - 12 editions, Simferopol - 10, Kherson - 8, Zhytomyr and Poltava - 6, Kamianets-Podilskyi and Yalta - 5, Chernihiv - 4, Kremenchuk - 2, Balaklava, Vinnytsia, Yelysavetgrad, Kerch, Myrhorod, Sevastopol, Sloviansk, Feodosia, Khorol, Khorol - 1 . The complete list of cities and the number of editions is given in table 1 .

In those cities of Naddniprianshchyna, where there were medical faculties at universities in the XIX - early XX centuries, the specialized information sphere is much more saturated than in others, even in the provincial centers to which Kherson, Simferopol, Poltava, Chernihiv, Katerynoslav belonged. Although the number of practitioners in these cities is not inferior to university cities: "most of the doctors were in the service in Poltava county - 95 people. In... Kharkiv, Kherson and 
Chernihiv governments their number ranged from 78 to 62 people in the province" 12 .

Table 1

List of cities and the number of editions

\begin{tabular}{|l|l|l|l|}
\hline City & Number & City & Number \\
\hline Balaclava & 1 & Poltava & 6 \\
\hline Vinnytsia & 1 & Sevastopol & 1 \\
\hline Yelysavetgrad & 1 & Simferopol & 10 \\
\hline Zhytomyr & 6 & Sloviansk & 1 \\
\hline Kamianets-Podilskyi & 5 & Feodosia & 1 \\
\hline Katerynoslav & 12 & Kharkiv & 34 \\
\hline Kerch & 1 & Kherson & 8 \\
\hline Kyiv & 52 & Khorol & 1 \\
\hline Kremenchuk & 2 & Khorol & 1 \\
\hline Myrhorod & 1 & Chernihiv & 4 \\
\hline Odesa & 35 & Yalta & 5 \\
\hline
\end{tabular}

It is obvious that social communication of the mid XIX - early $\mathrm{XX}$ centuries from the modern one differed significantly, its forms and methods were others, (based on developments in historical studies of the journalism structure in the system of socio-communicative activities (history of communication, press, genres, separate editions, etc.)). O. Sedelnikova writes about this: "many public institutions of that time have not yet received independence and narrow subject specialization"13. So it may be fair to think that it's not entirely correct to apply a modern typology to the press of that time. This can be considered absolute in relation to virtually all social institutions of that time, except one medicine. Its communicative functions - both as a science and as a practical activity - were significantly different from others. There are several factors that make this clear. The first of these is related to the development of science - French explorer Paul Tannery in paper “L'histoire des sciences en Europe depuis le XIVe siècle jusqu'à 1900",

${ }^{12}$ Пирумова Н. М. Земская интеллигенция и ее роль в общественной борьбе до начала XX в. Москва : Наука, 1986. Ст. 118.

${ }^{13}$ Седельникова О. В. К определению типа дискурсивной организации русской журнальной периодики середины ХІХ в. Язык и культура. 2012. № 1. Ст. 37. 
assessing the development of science, emphasized: "in the face of bacteriological discoveries, the history of other natural sciences seems somewhat bleak in the last decades of the XIX century"14.

The second factor is the close connection, like no other industry, science and practice, which was supported by a high level of communication. The third factor is the readership of medical specialized editions was overwhelmingly composed of experts that influenced both the content and the level of the material presentation. The fourth factor is the number of publications. According to our calculations 186 editions were published in Naddniprianshchyna from the middle of the XIX - early $\mathrm{XX}$ centuries, which is not observed in any other sphere of human activity.

Specialized medical periodicals and serials referred to the press that: “a) was intended for people of the unique - biomedical - sphere, b) its content predominated information for scientific, popular scientific and practical areas studying normal and pathological processes in the body, various diseases, pathological conditions, methods of prevention and improvement of human health; c) it differed greatly by the pragmatic value and the specificity of purpose and served to satisfy the information interests of the target audience" ${ }^{\prime 15}$.

The process of saturation of the information space by specialized medical periodicals and continuing editions reflected the process of becoming and improving medicine - as science and practice, the process of expanding the network of medical institutions and clinics, systematization of medical education etc.

Saturation of the information space with the medical press is determined by three factors: frequency, intensity, duration of release.

Analysis of Chart 1 "Frequency of release" gives grounds to claim that the most significant filling of information space with specialized messages took place within one month. This includes items $1-6$, that is, daily, weekly, biweekly, monthly editions, as well as those, that are

${ }^{14}$ Tannery P. L'histoire des sciences en Europe depuis le XIVe siècle jusqu'à 1900. Revue d'histoire des sciences et de leurs applications. T. XVII. Paris, 1950. P. 123.

15 Садівничий В. О. Типологічна система спеціалізованої медичної преси (на прикладі видань Наддніпрянської України середини XIX - початку XX ст.). Журналістика : наук. зб. Київ : Інститут журналістики КНУ імені Тараса Шевченка, 2015. Вип. 14 (39). Ст. 59. 
published 1-4 times a week and 20 times a year. The total number of periodicals and continuing editions that have been published for one month is 101. Of these, 56 are newspapers and magazines that are published once a month.

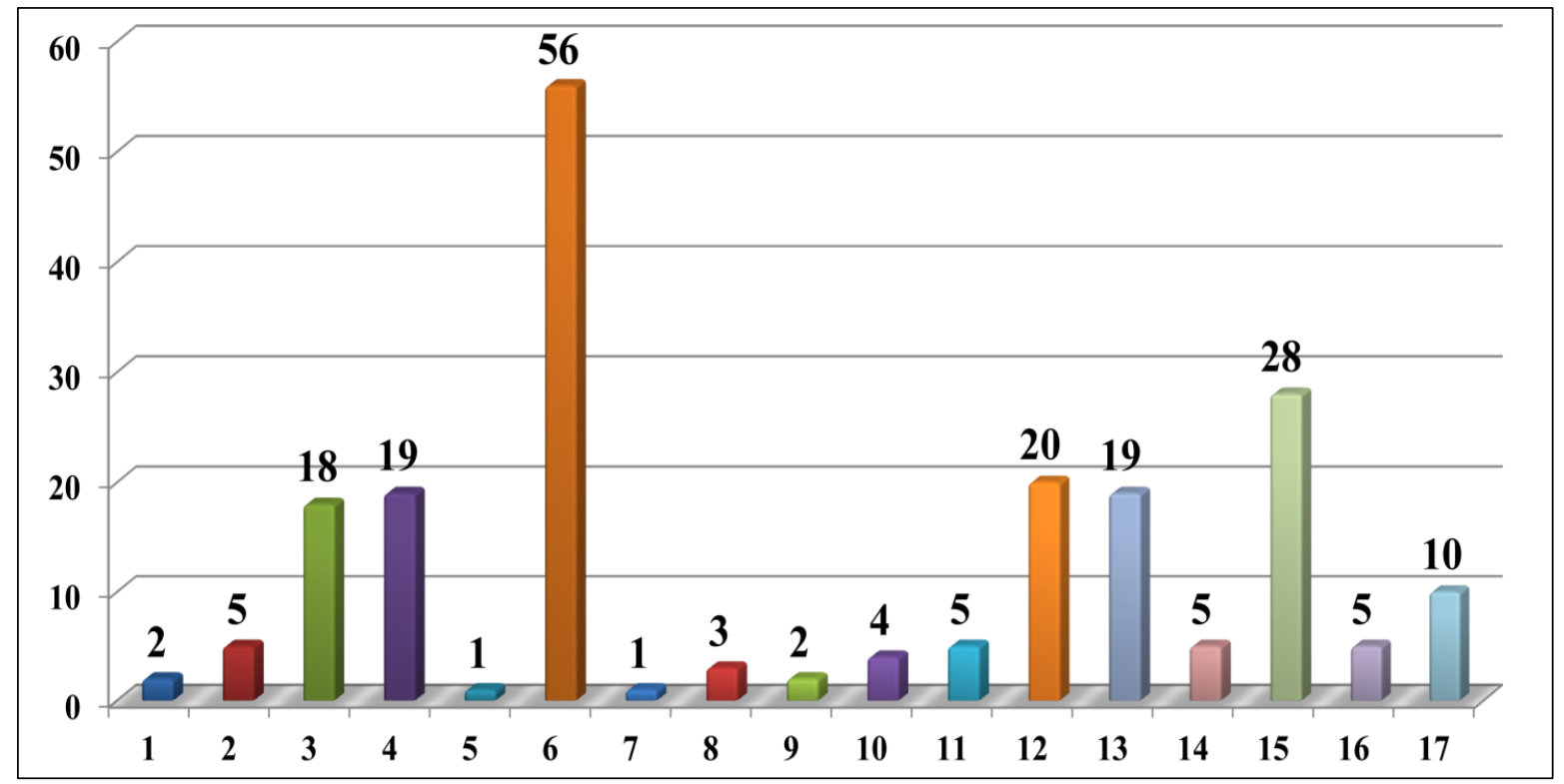

1 - daily; 2-1-4 times a week; 3 - weekly; 4 - two weeks; 5 - 20 times a year; 6 monthly; 7 - 10 times a year; 8 - two months; $9-2-4$ times a year; 10 - quarterly; 11 - six months; 12 - annual; 13 - without clear fixing of the release; 14 - one-day; 15 - release once; 16 - seasonal; 17 - frequency is not defined.

\section{Chart 1. Frequency of release}

The intensity of specialized press is important for the saturation of the information space - a fixation indicator of the number of editions that were published in a certain period of time, and the duration of their release. Generalized information of intensity by year is indicated by the curve, presented in Chart 2.

By 1882, the number of editions was growing rather gradually, 1-2 editions were added every year. The three peaks of growth, which can be clearly seen in the graph, are in 1894 (29 editions), 1901 (41 editions) and 1911 (65 editions). Since 1914, we have seen a decrease in saturation, when 10 editions were annually stopped and their number decreased to two in 1920. This decrease was first associated with the events of the First World War and then with the revolutions of 1917-1920. 


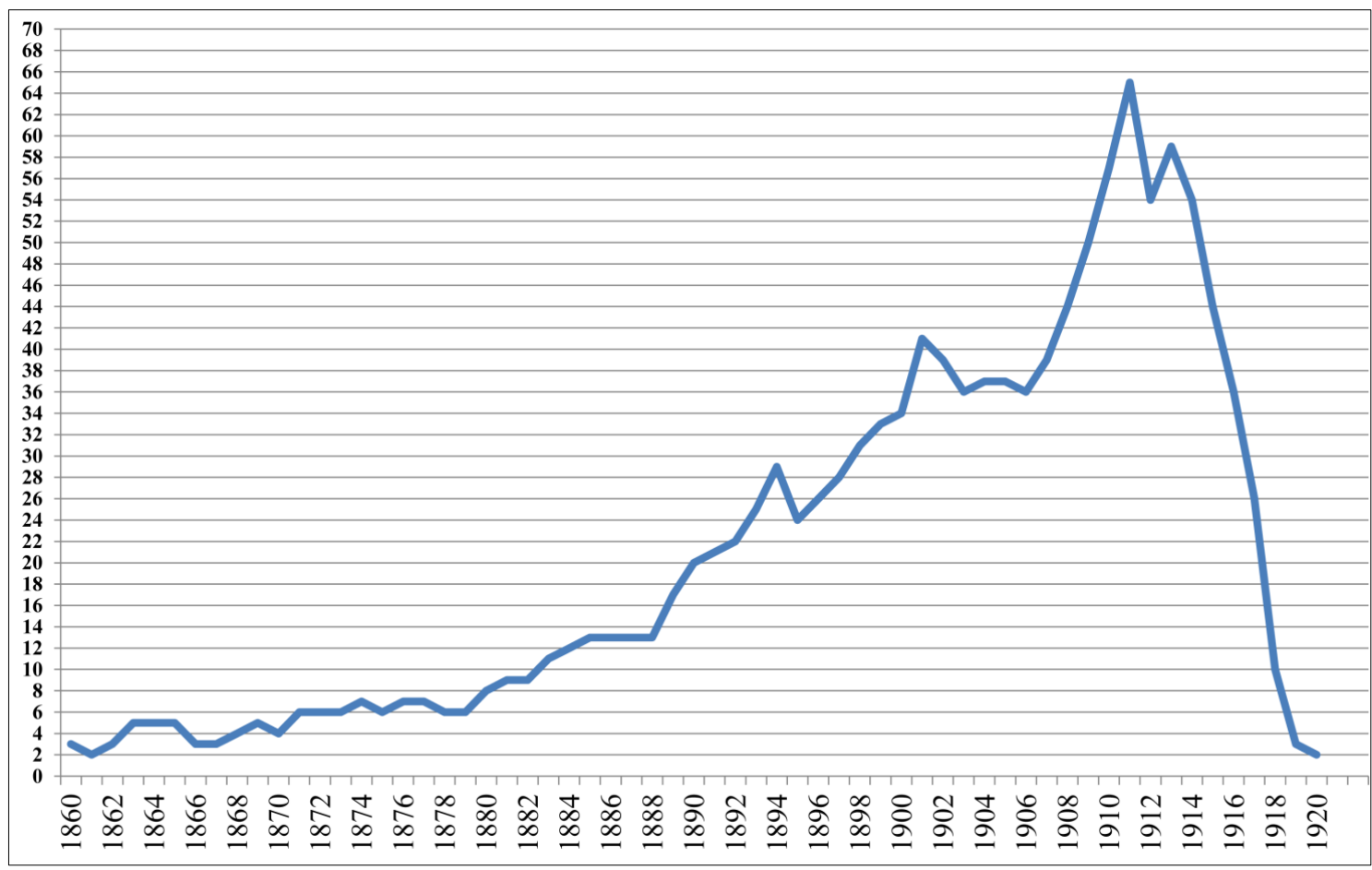

\section{Chart 2. Intensity of specialized press}

The general results of the analysis of the duration of medical press release in Naddniprianshchyna are presented in Chart 3.

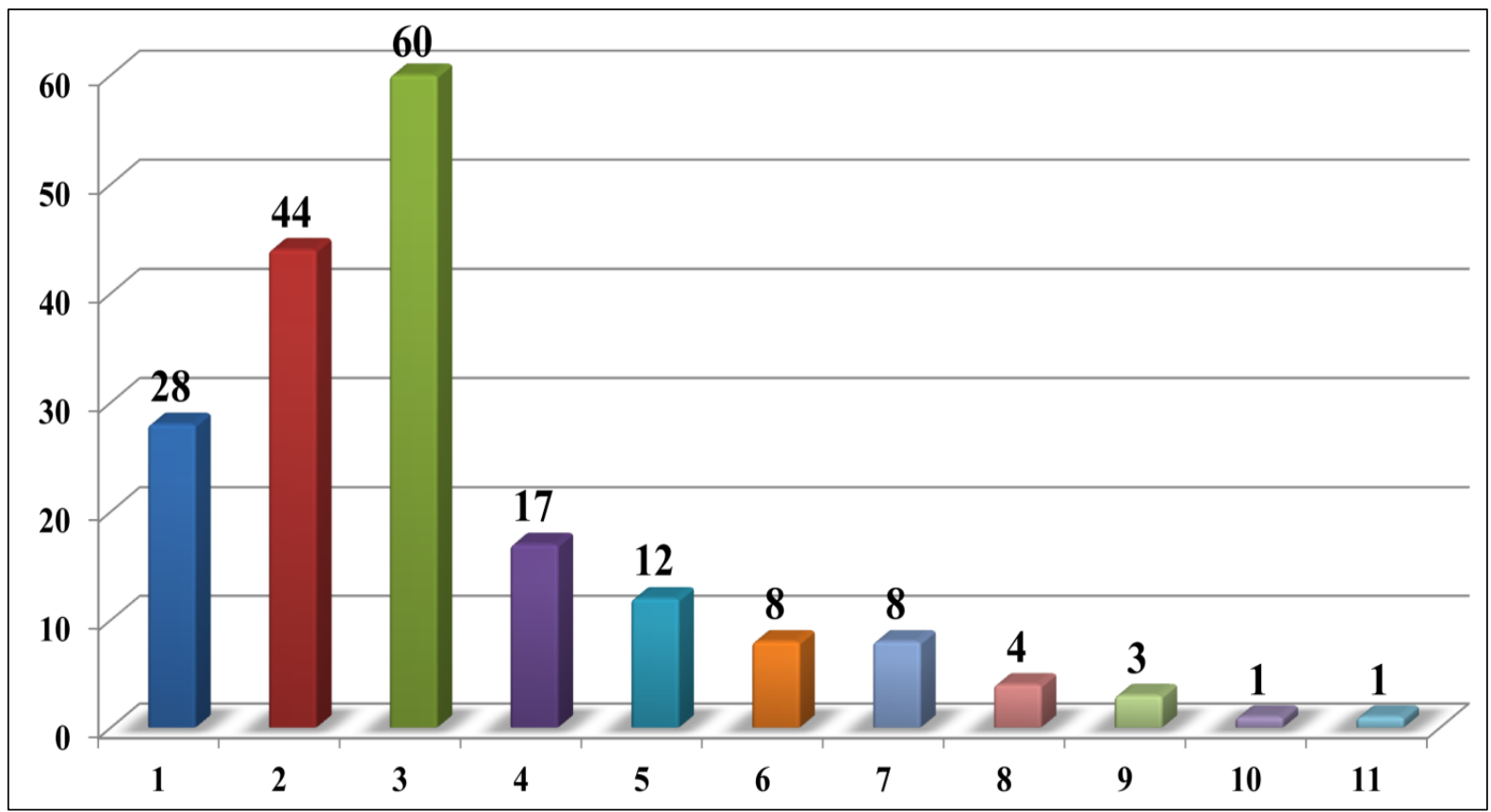

1 - release once; 2 - release to one year; $3-1-5$ years; $4-6-10$ years; $5-11-15$ years; $6-16-19$ years; $7-20-24$ years; $8-25-29$ years; $9-31-35$ years; $10-45$ years; $11-53$ years.

Chart 3. Duration of medical press release 


\section{Features of emergence and formation of medical periodicals in Naddniprianshchyna}

Specialized medical periodicals and continuing editions for their appearance in the information space of Naddniprianshchyna had some ground, formed by a number of significant factors.

One of the fundamental factors is the influence of scientific discoveries of the XVIII-XIX centuries, which created the foundation of medical and biological knowledge, contributed to their development and clinical application: "The remarkable achievements of natural science and philosophical idea, the creation of new scientific centers, the beginning of the widespread dissemination of natural science in society have contributed to an even more rapid rise of scientific knowledge, which took place in the second half of the XIX century, starting in the 60 's" 16 , S. Ruda characterizes that period.

F. Engels called the "three great discoveries" among the most significant natural achievements of the late XVIII and first half of the XIX centuries, which were further decisive for the development of dialectical views on nature and the development of medicine. These are the theory of the cellular structure of living organisms, the law of energy conservation and transformation, and evolutionary doctrine ${ }^{17}$, which explained all the basic processes in nature by natural causes.

These processes led to the accumulation and systematization of knowledge about the laws of nature, an integral part of which is the human body. Their accumulation has always changed the formation of the scientific picture of the world, introducing and justifying new laws of development.

Another factor is the rise of medical practice. Along with the development of science, the capitalization of society influenced him from the second half of the XIX century. This capitalization had an impact on the Russian Empire.

\footnotetext{
${ }^{16}$ Руда С. П. Становлення мікробіологічної науки в Україні: гносеологічні та інституціональні аспекти : автореф. дис. ... канд. істор. наук : 07.00.07. Київ, 2001. 20 с. Ст. 1.

17 Энгельс Ф. Из истории науки. Диалектика природьл. Москва : Госполитиздат, 1953. Ст. 155-156.
} 
The development of both industrial production and agriculture prompted doctors to survey the working conditions and health of workers in industrial enterprises and agricultural industries where mechanization was gaining ground. 90's of the XIX century characterized by the development of sanitation and preventive medicine. In view of this, the posts of county sanitary doctors are being introduced in the counties.

Initial reforms have contributed to the steady increase a number of newspapers and magazines: the introduction of the university charter in 1863 , the county and judicial reforms in 1864 , the educational reform in $1863-64$, the urban reform in 1870, and others. On the basis of reforms, a reorganization of the local government system took place: the existing feudal basis was replaced by decentralization and involvement in government. The first specialized medical edition introduced by a local government is "Trudyi postoyannoy meditsinskoy komissii pri Poltavskoy gubernskoy zemskoy uprave"/"Proceedings of the Standing Medical Commission at the Poltava Provincial County Council" (1869).

"Vrachebno-sanitarnyie hroniki"/"Medical and Sanitary Chronicles", which was published in virtually all provinces, addressed the employees of county medicine, reported on the activities of the county administration in the sphere of public health. They submitted resolutions of the provincial county assembly, notes about the surveillance of epidemic diseases and the geography of their distribution, reports about the activity of medical districts, vaccinations, medical reports (often in the form of tables), protocols of meetings of county doctors' congresses, programs of their activities, reviews of county medical press, reprints of foreign periodicals, correspondence, announcements.

Among other things, the medicine contribution to the state development was characterized by the accumulation and synthesis of empirical knowledge about human diseases; new discoveries in the sphere of biomedical sciences; the development and emergence of new clinical disciplines; development of vaccines for the treatment and prevention of fatal diseases; study of occupational diseases and establishment of factory hygiene, directly related to the industry development; formation of social, teenage, communal hygiene, etc.; establishment of preventive medicine, etc. 
The development of the business of treatment people, which had resolved by counties from the second half of the XIX century, could not be successful without the training of medical staff. Accordingly, the state developed existing ones and created new medical faculties at universities.

Medical faculties, playing a significant role in shaping the professional environment, also became centers where people from one professional community met. Of course, they varied on a number of features, such as education, intellectual level, social status, property status, age, and so on. But they were united by their desire to exchange theoretical and practical knowledge.

Universities had a solid printing base at the time. Accordingly, cities Kyiv, Kharkiv, Odesa - where medical faculties operated at universities, first and foremost became centers of advent of the specialized press.

The medical faculties also formed the professional environment that gave birth to both the producers of specialized information, its disseminators in the person of editors and publishers, as well as recipients, professional consumers.

End of XIX - beginning of XX century is also characterized by the growth of scientific societies, special commissions and other public health organizations. They included not only doctors but also other intellectuals. This testify to the consolidating role of physicians as representatives of the most educated intellectuals, in uniting citizens to protect people's interests and create conditions for self-fulfillment. This exacerbated the impact on the society of medical knowledge. Accordingly, a social order for specialized information emerged and the task of storing and transmitting it was set up.

According to the actual data that O. Tsiborovskyi points out, "The first scientific society of doctors in the country was established in Kherson in 1784 on the initiative of D. S. Samoilovych. Soon... the Society of Kiev doctors was founded in 1840, the Society of Odesa doctors - in 1849, The Society of Volyn, Podil, Kharkiv Medical Societies respectively in 1859, 1860 and $1861 \%$. In general, there were scientific societies, charitable

${ }^{18}$ Ціборовський О. М. Наукове і практичне значення досліджень 3 історії української медицини. Україна. Здоров'я нащії. 2012. № 1 (21). Ст. 169. 
medical organizations, and professional medical associations in the medical spheres.

Speaking about the prerequisites, it is necessary to refer to the right opinion of S. Makhonina: "with the development of the journalism system at the turn of the XIX and XX centuries there are a number of different types of editions that not only reflect the development of ... culture, but also become indicators of the cultural level of social development. First of all, these are editions on various issues of literature and art, popular science and some others"19.

Analysis of the medical press of Naddniprianshchyna in the mid XIX - early XX centuries gives us reason to argue that editions are universal-themed and mono-themed in terms of thematic and content characteristics. Accordingly, they are divided into: a) publications in the spheres of therapy, surgery, dentistry, obstetrics and gynecology, psychiatry and neurology, ophthalmology, pharmacy, radiology, skin and venereal diseases, pediatrics, physiotherapy, balneology, disaster medicine, military medicine, veterinary medicine; b) editions in theoretical, practical and evidential medicine; c) medical and veterinary bacteriology; d) epidemiology; e) alternative medicine - homeopathy; e) lifestyle and nutrition - hygiene, vegetarianism; e) cross-industry editions; g) advertising editions.

Editions in various spheres of medicine have taken a significant place: ophthalmology, neurology, psychiatry, pharmacy. A number of factors contributed to the emergence of these journals, among which the development of science, the emergence of relevant departments at medical institutes, the study of various diseases, the change of attitude to specific patients, etc.

Sectoral editions were published 49: newspapers -7 , magazines by content -22 , magazines by form -20 .

The distribution of editions in certain spheres of medicine was very uneven. If you take the provinces, the situation looks like this:

${ }^{19}$ Махонина С. Я. История русской журналистики начала XX века : учебн. пособ. Москва : Флинта ; Наука, 2004. URL: http://evartist.narod.ru/textl/84htm (дата звернення: 18.02.2020). 
Kherson - 19; Kharkiv - 16; Kyiv - 12; Tavriya - 9; Katerynoslav - 6; Podil - 3; Volyn - 2; Poltava - 1 .

By purpose (based on our research, the basis of which was the texts topic analysis, especially editorials, as well as the analysis of stated concepts), specialized medical periodicals and continuing editions are divided as follows: general medical direction, sectoral, applied, advertising-information, scientific, scientific-popular, popular, officialdocumentary, chronic-documentary, statistical, reference.

The most numerous by purpose is the edition of general medical direction.

Scientific publications include "Zapiski..."/"Notes..." of medical societies and educational institutions, "Protokolyi..."/"Protocols..." and "Trudyi..."/"Labor..." of medical societies, and others - total 59.

The publications stood out for the high scientific level which was proved by important conclusions and formulated scientific approach. According to functionality, the texts divided into reviews, methodological, empiric and factual, theoretical, explanatory, supplementary and mixed types. Every paper included author's opinion and a certain analysis of the performed work. The prevailing way of information representation is the esoteric one, according to which ideas, theories, conclusions, etc. were meant for well-informed people, i.e. understandable only for specialists. The main areas of theoretical and academic content included: insufficiently studied and new diseases for that time; original methods of treating them; theoretical and practical researches which concerned practicing physicians, privat-docents, professors and enabled them to follow the development of national and international medical and biological science. A separate place was given to abstracts of mostly practical and theoretical content from foreign periodicals, books, serials.

The group of official and documentary editions is formed by "Bulletins ...", "Vedomosti...", “Reviews...", "Information..." and "Chronicles...". The founders or publishers were provincial and county administrations, provincial county sanitary administrations, sanitary and medical bureaus of public health departments of city administrations, 
sanitary departments of county and city administrations, counties, city sanitary stations, city public administrations.

The main function of official publications is to convey professional information to meet the needs of its target audience. It is the function that determines the subject-matter direction - to submit professional information of a utilitarian nature. These include: circulars from the Department of the Interior's Medical Department, official notices and orders from the Provincial County Administration, journals and minutes of various meetings, reports on medical trips of doctors, diagnostic studies, forms of various reports, changes in the cast of county medical staff, experience of health services work abroad, journals of veterinary councils meetings, review of county medical press, reprints from Russian and foreign periodicals, occupational health, the life and education of doctors and their assistants, information about orphans and abandoned children brought up at the expense of county self-government, activity of Pasteur stations, arrangement of shelters, organization of medical and sanitary assistance to refugees and work of school doctors, etc.

In substantiating the history, theory, and development of the specialized information space, we emphasize the particular importance of agents of scientific and practical activity, who were involved in the production and consumption of information, in understanding the need to disseminate knowledge and obtain information from others. Agents in the biomedical sphere were: students, associate professors and professors of medical faculties of three universities in Naddniprianshchyna (Kyiv, Kharkiv, Odesa) and Kharkiv Veterinary Institute; employees of research institutes - Bacteriological institute of Kharkov medical society, Odesa bacteriological station, Kyiv Bacteriological Institute, veterinary bacteriological and sanitary laboratories, etc.; members of scientific medical societies and other public associations of biomedical and veterinary directions, heads of departments of county and medical services of cities.

The audience was not only the consumer of the information that was being offered, but also evaluated it, took an active part in the production, influenced the thematic policy. That is, we have an audience with a 
specific interest structure. We can say that the editions were intended for the mass reader or for a specialized audience by distinguishing the auditory features of the analyzed press.

According to the language: Ukrainian was published 9, Polish - 2, Russian - 175. The Ukrainian- language editions were: Kyiv - 6, Poltava - 2,

Khotyn -1 . In terms of frequency, these were: bi-weekly -3 , monthly -4 , indefinitely -1 .

\section{CONCLUSIONS}

The socio-communicative aspects of specialized health information differed significantly from others. This is clearly demonstrated by three factors. The first is related to the development of science; the second is a close, inseparable link between science and practice; the third - a readership that was actually entirely made up of experts.

The emergence of new, thematic-meaningful transformation of existing specialized medical periodicals and continuing editions, growth of their activity, implementation of editorial programs contributed to the expansion of the segment of information products and services in the general structure of the national information space, filling it with highquality specialized information. The main focus of the specialized medical information space is to address the challenges of the institutional health care system by ensuring the communicative functions of the sphere. The specialized medical information space of Naddniprianshchyna in the second half of the XIX - beginning of the XX centuries characterized by the development of social institutions (higher education institutions, scientific and other societies, research organizations, medical institutions); by saturation of the generated and reproduced medical knowledge; by presence of professional communication agents; by corporate using; by a community of typological features whose properties are defined by information infrastructure; by the fact that there are specialized medical periodicals and continuing editions.

Focusing on specialists and the mass reader, the medical press more dynamically and comprehensively showed the development of the medical business at that time took care of improving the skills of specialists, took 
care of protecting the interests of health workers, promoting a healthy lifestyle.

\section{SUMMARY}

The history and principles of formation of specialized medical space on the example of Naddniprianshchyna are investigated. In the period from 1860 to 1920,186 specialized medical periodicals and continuing editions were published in 9 provinces (Volyn, Katerynoslav, Kyiv, Podil, Poltava, Tavriy, Kharkiv, Kherson, Chernihiv). Research result: the specialized medical information space of Naddniprianshchyna in the second half of the XIX - beginning of the XX centuries characterized by the development of social institutions (higher education institutions, scientific and other societies, research organizations, medical institutions); richness of the generated and reproductive medical knowledge; professional communication agents (medical scientists, medical practitioners and clinicians, nursing staff, students); corporate using; a community of typological features whose properties are defined by information infrastructure; the fact that there are specialized medical periodicals and continuing editions. The main focus of the specialized medical information space is to address the challenges of the institutional health care system by ensuring the communicative functions of the area.

\section{REFERENCES}

1. Кононович В. Г. Визначення інформаційного поля з позицій інформаційної безпеки. “АВІА-2011”: Матеріали Хміжнародної науково-технічної конференції. Секція 2 - Інформаційна безпека. Київ : НАУ, 2011. С. 2.34-2.37.

2. Плескач В. Л., Затоноцька Т.Г. Інформаційні системи i технології на підприємствах : підручн. Київ : Знання, 2011. 718 с. URL: http://pidruchniki.com/1350052747708/informatika/ponyattya_informatsiyno go_prostoru (дата звернення: 15.02.2020).

3. Медицинская периодическкая печать. Большая медищинская эниңиклопедия. Москва : Советская энциклопедия, 1980. Т. 14. Ст. 377. 
4. Медицина. Большая медицинская энциклопедия. Москва : Советская энциклопедия, 1980. Т. 14. Ст. 3.

5. Соціально-філософські та етичні проблеми медицини : навч. посіб. ; за заг. ред. А. П. Алексеєнко, В. М. Лісового. Харків : Колегіум, 2010. 340 c.

6. Гомеопатия. Большая медицинская энщииклопедия. - Москва : Советская энциклопедия, 1977. Т. 6. С. 307-309.

7. Соціально-філософські та етичні проблеми медицини : навч. посіб. ; за заг. ред. А. П. Алексеєнко, В. М. Лісового. Харків : Колегіум, 2010. 340 с.

8. Садівничий В. О. Становлення вітчизняного інформаційного простору в сегменті медичної преси наддніпрянської України XIX початку XX століть: типологія, функціонально-змістові особливості, комунікативно-прагматичні складники : дис. ... д-ра наук із соц. комунік : 27.00.04. Київ, 2015. 481 с.

9. ДСТУ 7152:2010. Видання. Основні види: Терміни та визначення. [Чинний від 1996-01-01]. Вид. офіц. Київ, 1995. 48 с. (Інформація та документація).

10. Семистяга Т. Видавничо-поліграфічна галузь України: динаміка й проблеми розвитку (2002-2004 роки). Друкарство. 2005. № 2. С. 5-8.

11. Садівничий В. "Відродження розпочинається із гласності..." : (Медична преса Наддніпрянської України середини XIX - початку XX ст.) : монографія. Дніпропетровськ : Середняк Т. К., 2015. 360 с.

12. Пирумова Н. М. Земская интеллигенция и ее роль в общественной борьбе до начала ХХ в. Москва : Наука, 1986. 268 с.

13. Седельникова О. В. К определению типа дискурсивной организации русской журнальной периодики середины XIX в. Язык $u$ культура. 2012. № 1. C. 36-42.

14. Tannery P. L'histoire des sciences en Europe depuis le XIVe siècle jusqu'à 1900. Revue d'histoire des sciences et de leurs applications. T. XVII. Paris, 1950. P. 123-434.

15. Садівничий В. О. Типологічна система спеціалізованої медичної преси (на прикладі видань Наддніпрянської України 
середини XIX - початку XX ст.). Журналістика : наук. зб. Київ : Інститут журналістики КНУ імені Тараса Шевченка, 2015. Вип. 14 (39). С. 32-45.

16. Руда С. П. Становлення мікробіологічної науки в Україні: гносеологічні та інституціональні аспекти : автореф. дис. ... канд. істор. наук : 07.00.07. Київ, 2001. 20 с.

17. Энгельс Ф. Из истории науки. Диалектика природыл. Москва : Госполитиздат, 1953. С. 145-158.

18. Ціборовський О. М. Наукове i практичне значення досліджень 3 історії української медицини. Україна. Здоров'я нації. 2012. № 1 (21). С. 168-173.

19. Махонина С. Я. История русской журналистики начала XX века : учебн. пособ. Москва : Флинта ; Наука, 2004. URL: http://evartist.narod.ru/textl/84htm (дата звернення: 18.02.2020).

\section{Information about the author: Sadivnychyi V. O.,}

D.Sc. in Social Communications, Associate Professor at the Department of Journalism and Philology, Sumy State University 2, Rymsky-Korsakov str., Sumy, 40007, Ukraine 
NOTES 
NOTES 
Publishing house "Liha-Pres"

9 Kastelivka str., Lviv, 79012, Ukraine

44 Lubicka str., Toruń, 87-100, Poland

Printed by the publishing house "Liha-Pres"

Passed for printing: September 17, 2019.

A run of 150 copies. 